\title{
ISSN 2304-2338
}

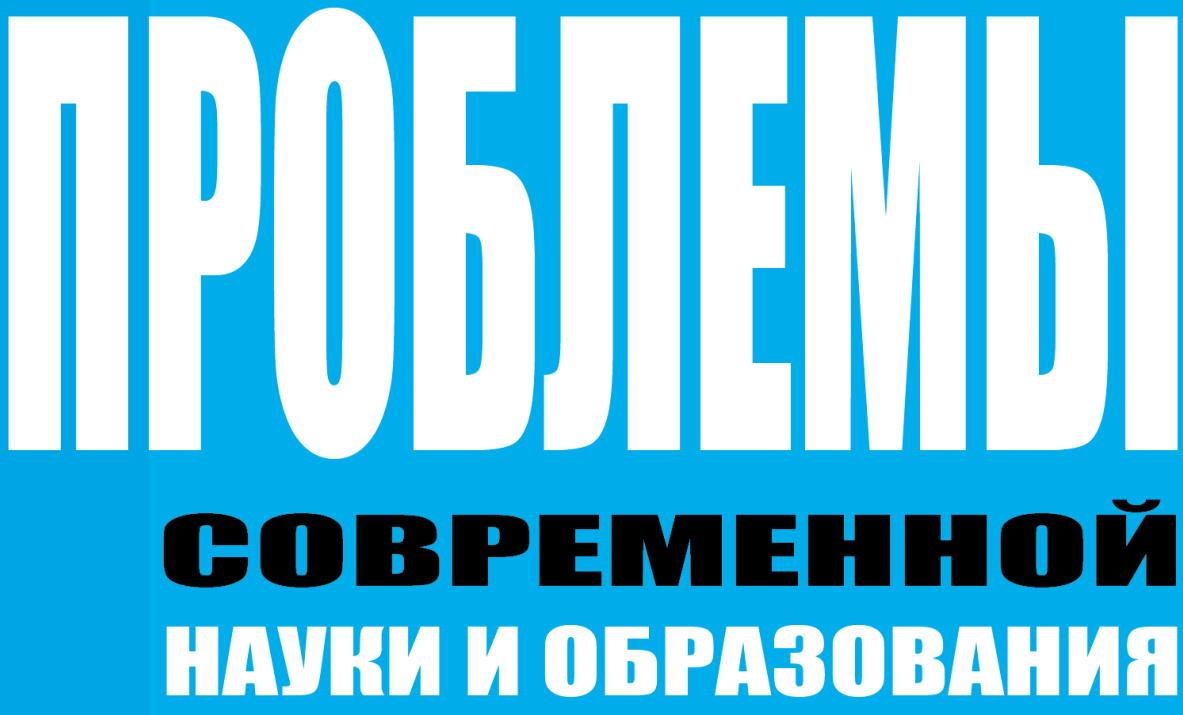

PROBLEMS OF MODERN SGENGE AND EDUGATION DOI: 10.20861/2304-2338-2017-91 


\title{
PROBLEMS OF MODERN SCIENCE AND EDUCATION
}

\author{
2017. № 9 (91) \\ DOI: $10.20861 / 2304-2338-2017-91$ \\ Импакт-фактор РИНЦ: 2,13 \\ EDITOR IN CHIEF \\ Valtsev S.
}

\section{EDITORIAL BOARD}

\begin{abstract}
Abdullaev K. ( $\mathrm{PhD}$ in Economics, Azerbaijan), Alieva V. ( $\mathrm{PhD}$ in Philosophy, Republic of Uzbekistan), Akbulaev N. (D.Sc. in Economics, Azerbaijan), Alikulov S. (D.Sc. in Engineering, Republic of Uzbekistan), Anan'eva E. (D.Sc. in Philosophy, Ukraine), Asaturova A. (PhD in Medicine, Russian Federation), Askarhodzhaev N. (PhD in Biological Sc., Republic of Uzbekistan), Bajtasov R. (PhD in Agricultural Sc., Belarus), Bakiko I. (PhD in Physical Education and Sport, Ukraine), Bahor T. (PhD in Philology, Russian Federation), Baulina M. (PhD in Pedagogic Sc., Russian Federation), Blejh N. (D.Sc. in Historical Sc., PhD in Pedagogic Sc., Russian Federation), Bogomolov A. (PhD in Engineering, Russian Federation), Borodaj V. (Doctor of Social Sciences, Russian Federation), Volkov A. (D.Sc. in Economics, Russian Federation), Gavrilenkova I. (PhD in Pedagogic Sc., Russian Federation), Garagonich V. (D.Sc. in Historical Sc., Ukraine), Glushhenko A. (D.Sc. in Physical and Mathematical Sciences, Russian Federation), Grinchenko V. (PhD in Engineering, Russian Federation), Gubareva T. (PhD Laws, Russian Federation), Gutnikova A. (PhD in Philology, Ukraine), Datij A. (Doctor of Medicine, Russian Federation), Demchuk N. (PhD in Economics, Ukraine), Divnenko O. (PhD in Pedagogic Sc., Russian Federation), Dolenko G. (D.Sc. in Chemistry, Russian Federation), Esenova K. (D.Sc. in Philology, Kazakhstan), Zhamuldinov V. (PhD Laws, Kazakhstan), Zholdoshev S. (Doctor of Medicine, Republic of Kyrgyzstan), Ibadov R. (D.Sc. in Physical and Mathematical Sciences, Republic of Uzbekistan), Il'inskih N. (D.Sc. Biological, Russian Federation), Kajrakbaev A. (PhD in Physical and Mathematical Sciences, Kazakhstan), Kaftaeva M. (D.Sc. in Engineering, Russian Federation), Kikvidze I. (D.Sc. in Philology, Georgia), Koblanov Zh. (PhD in Philology, Kazakhstan), Kovaljov M. (PhD in Economics, Belarus), Kravcova T. (PhD in Psychology, Kazakhstan), Kuz'min S. (D.Sc. in Geography, Russian Federation), Kulikova E. (D.Sc. in Philology, Russian Federation), Kurmanbaeva M. (D.Sc. Biological, Kazakhstan), Kurpajanidi K. (PhD in Economics, Republic of Uzbekistan), Linkova-Daniels N. (PhD in Pedagogic Sc., Australia), Lukienko L. (D.Sc. in Engineering, Russian Federation), Makarov A. (D.Sc. in Philology, Russian Federation), Macarenko T. ( $\mathrm{PhD}$ in Pedagogic Sc., Russian Federation), Meimanov B. (D.Sc. in Economics, Republic of Kyrgyzstan), Muradov Sh. (D.Sc. in Engineering, Republic of Uzbekistan), Nabiev A. (D.Sc. in Geoinformatics, Azerbaijan), Nazarov R. (PhD in Philosophy, Republic of Uzbekistan), Naumov V. (D.Sc. in Engineering, Russian Federation), Ovchinnikov $J u$. (PhD in Engineering, Russian Federation), Petrov V. (D.Arts, Russian Federation), Radkevich M. (D.Sc. in Engineering, Republic of Uzbekistan), Rakhimbekov S. (D.Sc. in Engineering, Kazakhstan), Rozyhodzhaeva G. (Doctor of Medicine, Republic of Uzbekistan), Romanenkova Yu. (D.Arts, Ukraine), Rubcova M. (Doctor of Social Sciences, Russian Federation), Rumyantsev D. (D.Sc. in Biological Sc., Russian Federation), Samkov A. (D.Sc. in Engineering, Russian Federation), San'kov P. (PhD in Engineering, Ukraine), Selitrenikova T. (D.Sc. in Pedagogic Sc., Russian Federation), Sibircev V. (D.Sc. in Economics, Russian Federation), Skripko T. (D.Sc. in Economics, Ukraine), Sopov A. (D.Sc. in Historical Sc., Russian Federation), Strekalov V. (D.Sc. in Physical and Mathematical Sciences, Russian Federation), Stukalenko N.M. (D.Sc. in Pedagogic Sc., Kazakhstan), Subachev Ju. (PhD in Engineering, Russian Federation), Sulejmanov S. (PhD in Medicine, Republic of Uzbekistan), Tregub I. (D.Sc. in Economics, PhD in Engineering, Russian Federation), Uporov I. (PhD Laws, D.Sc. in Historical Sc., Russian Federation), Fedos'kina L. (PhD in Economics, Russian Federation), Khiltukhina E. (D.Sc. in Philosophy, Russian Federation), Cuculjan S. (PhD in Economics, Republic of Armenia), Chiladze G. (Doctor of Laws, Georgia), Shamshina I. (PhD in Pedagogic Sc., Russian Federation), Sharipov M. (PhD in Engineering, Republic of Uzbekistan), Shevko D. (PhD in Engineering, Russian Federation).
\end{abstract}

Publishing house «PROBLEMS OF SCIENCE»

Frequency: weekly

153008, Russian Federation, Ivanovo, Lezhnevskaya st., h.55, 4th floor. Phone: +7 (910) 690-15-09.

http://www.ipi1.ru/ e-mail: info@p8n.ru

Distribution: Russian Federation, foreign countries

Moscow

2017 


\section{Проблемы современной науки и образования 2017. № 9 (91)}

DOI: $10.20861 / 2304-2338-2017-91$

Импакт-фактор РИНЦ: 2,13

\section{НАУЧНО-МЕТОДИЧЕСКИЙ ЖУРНАЛ}

\section{Главный редактор: Вальцев С.В.}

\section{Периодичность:} еженедельно

Подписано в печать: 08.03.2017.

Дата выхода в свет: 10.03.2017.

\section{Формат 70х100/16.}

Бумага офсетная. Гарнитура «Таймс». Печать офсетная. Усл. печ. л. 9,75 Тираж 1000 экз. Заказ № 1105

\section{Территория} распространения: зарубежные страны, Российская Федерация

\section{ТИПОГРАФИЯ} ООО «ПресСто». 153025, г. Иваново, ул. Дзержинского, 39, строение 8

\section{ИЗДАТЕЛЬ} ООО «Олимп» 153002, г. Иваново, Жиделева, д. 19

\section{ИЗДАТЕЛЬСТВО} «Проблемы науки»

Свободная цена
Заместитель главного редактора: Ефимова А.В.

\section{РЕДАКЦИОННЫЙ СОВЕТ:}

Абдуллаев К.Н. (д-р филос. по экон., Азербайджанская Республика), Алиева В.P. (канд. филос. наук, узбекистан), Акбулаев Н.Н. (д-р экон. наук, Азербайджанская Республика), Аликулов С.P. (д-р техн. наук, Узбекистан), Ананьева Е.П. (д-р филос. наук, Украина), Асатурова А.В. (канд. мед. наук, Россия), Аскарходжаев Н.А. (канд. биол. наук, Узбекистан), Байтасов Р.Р. (канд. с.-х. наук, Белоруссия), Бакико И.В. (канд. наук по физ. воспитанию и спорту, Украина), Бахор Т.A. (канд. филол. наук, Россия), Баулина М.В. (канд. пед. наук, Россия), Блейх Н.О. (д-р ист. наук, канд. пед. наук, Россия), Богомолов А.В. (канд. техн. наук, Россия), Бородай В.А. (д-р социол. наук, Россия), Волков А.Ю. (д-р экон. наук, Россия), Гавриленкова И.В. (канд. пед. наук, Россия), Гарагонич В.В. (д-р ист. наук, Украина), Глущенко А.Г. (д-р физ.-мат. наук, Россия), Гринченко B.A. (канд. техн. наук, Россия), Губарева Т.И. (канд. юрид. наук, Россия), Гутникова А.В. (канд. филол. наук, Украина), Датий А.В. (д-р мед. наук, Россия), Демчук Н.И. (канд. экон. наук, Украина), Дивненко O.В. (канд. пед. наук, Россия), Доленко Г.Н. (д-р хим. наук, Россия), Есенова К.У. (д-р филол. наук, Казахстан), Жамулдинов В.Н. (канд. юрид. наук, Казахстан), Жолдошев С.T. (д-р мед. наук, Кыргызская Республика), Ибадов Р.М. (д-р физ.-мат. наук, Узбекистан), Ильинских Н.Н. (д-р биол. наук, Россия), Кайракбаев А.К. (канд. физ.-мат. наук, Казахстан), Кафтаева М.В. (д-р техн. наук, Россия), Киквидзе И.Д. (д-р филол. наук, Грузия), Кобланов Ж.Т. (канд. филол. наук, Казахстан), Ковалёв М.Н. (канд. экон. наук, Белоруссия), Кравиова T.M. (канд. психол. наук, Казахстан), Кузьмин С.Б. (д-р геогр. наук, Россия), Куликова Э.Г. (д-р филол. наук, Россия), Курманбаева М.С. (д-р биол. наук, Казахстан), Курпаяниди К.И. (канд. экон. наук, Узбекистан), Линькова-Даниельс Н.А. (канд. пед. наук, Австралия), Лукиенко Л.В. (д-р техн. наук, Россия), Макаров А. Н. (др филол. наук, Россия), Мацаренко Т.Н. (канд. пед. наук, Россия), Мейманов Б.К. (д-р экон. наук, Кыргызская Республика), Мурадов Ш.О. (д-р техн. наук, Узбекистан), Набиев А.A. (д-р наук по геоинформ., Азербайджанская Республика), Назаров Р.P. (канд. филос. наук, Узбекистан), Наумов В. А. (д-р техн. наук, Россия), Овчинников Ю.Д. (канд. техн. наук, Россия), Петров В.О. (д-р искусствоведения, Россия), Радкевич M.B. (д-р техн. наук, Узбекистан), Рахимбеков С.М. (д-р техн. наук, Казахстан), Розыходжаева Г.А. (д-р мед. наук, Узбекистан), Романенкова Ю.В. (д-р искусствоведения, Украина), Рубцова М.В. (д-р. социол. наук, Россия), Румянцев Д.Е. (д-р биол. наук, Россия), Самков А. В. (д-р техн. наук, Россия), Саньков П.Н. (канд. техн. наук, Украина), Селитреникова Т.A. (д-р пед. наук, Россия), Сибирцев В.A. (д-р экон. наук, Россия), Скрипко Т.A. (д-р экон. наук, Украина), Сопов А.В. (д-р ист. наук, Россия), Стрекалов В.Н. (д-р физ.-мат. наук, Россия), Стукаленко Н.М. (д-р пед. наук, Казахстан), Субачев Ю.В. (канд. техн. наук, Россия), Сулейманов С.Ф. (канд. мед. наук, Узбекистан), Трегуб И.В. (д-р экон. наук, канд. техн. наук, Россия), Упоров И.В. (канд. юрид. наук, д-р ист. наук, Россия), Федоськина Л.А. (канд. экон. наук, Россия), Хилтухина Е.Г. (д-р филос. наук, Россия), Цуиулян С.В. (канд. экон. наук, Республика Армения), Чиладзе Г.Б. (д-р юрид. наук, Грузия), Шамиина И.Г. (канд. пед. наук, Россия), Шарипов М.С. (канд. техн. наук, Узбекистан), Шевко Д.Г. (канд. техн. наук, Россия).

\section{АДРЕС РЕДАКЦИИ:}

153008, РФ, г. Иваново, ул. Лежневская, д.55, 4 этаж Тел.: +7 (910) 690-15-09.

http://www.ipi1.ru/ e-mail: info@p8n.ru

Журнал зарегистрирован Федеральной службой по надзору в сфере связи, информационных технологий и массовых коммуникаций (Роскомнадзор) Свидетельство ПИ № ФС 77-47745

Редакция не всегда разделяет мнение авторов статей, опубликованных в журнале Учредители: Вальцев Сергей Витальевич; Воробьев Александр Викторович

( Проблемы современной науки и образования / Problems of modern science and education, 2017 


\section{Содержание}

ФИЗИКО-МАТЕМАТИЧЕСКИЕ НАУКИ

Рубинштейн А.И., Городечкая Т.А., Серебренников П.С., Шипов Н.В., Шмаков А.В. ОБ ОДНОМ ЧАСТНОМ СЛУЧАЕ РЕШЕНИЯ ЗАДАЧИ ТРЕХ ТЕЛ / Rubinshtein A.I., Gorodetskaya N.A., Serebrennikov P.S., Shipov N.V., Shmakov A.V. ONE PARTICULAR CASE OF SOLVING THE PROBLEM OF THREE BODIES

Рубинштейн А.И., Городецкая Т.А., Серебренников П.С., Шипов Н.В., Шмаков А.В. О ДВУХ ЭЛЕМЕНТАРНЫХ ТЕОРЕТИКО-ЧИСЛОВЫХ ЗАДАЧАХ / Rubinshtein A.I., Gorodetskaya N.A., Serebrennikov P.S., Shipov N.V., Shmakov A.V. TWO ELEMENTARY NUMBER-THEORETIC PROBLEMS

Аблабеков Б.С., Байсеркеева А.Б. ОБРАТНАЯ ЗАДАЧА ОПРЕДЕЛЕНИЯ ФУНКЦИИ ИСТОЧНИКА В ПСЕВДОПАРАБОЛИЧЕСКОМ УРАВНЕНИИ С ИНТЕГРАЛЬНЫМ ПЕРЕОПРЕДЕЛЕНИЕМ / Ablabekov B.S., Baiserkeeva A.B. INVERSE PROBLEM OF DETERMINING THE SOURCE FUNCTION IN PSEUDOPARABOLIC EQUATIONS WITH INTEGRAL OVER DETERMINATION.

Омуров Т.Д., Алиева А.Р. ЗАДАЧА КОШИ ДЛЯ СИНГУЛЯРНОВОЗМУЩЕННОГО ИНТЕГРО-ДИФФЕРЕНЦИАЛЬНОГО УРАВНЕНИЯ С ДВУМЯ МАЛЫМИ ПАРАМЕТРАМИ / Omurov T.D., Alieva A.R. ТНЕ CAUCHY PROBLEM FOR SINGULARLY PERTURBED INTEGRODIFFERENTIAL EQUATIONS WITH TWO SMALL PARAMETERS

Чекеев А.А., Абдраимова М.А., Чанбаева А.И. ПОЛНЫЕ СЕМЕЙСТВА UНЕПРЕРЫВНЫХ ФУНКЦИЙ / Chekeev A.A., Abdraimova M.A., Chanbaeva A.I. A COMPLETE FAMILIES OF U- CONTINUOUS FUNCTIONS ....

Чекеев А.А., Касымова Т.Д., Рахманкулов Б.3. ИНВЕРСНО-ЗАМКНУТЫЕ АЛГЕБРЫ ФУНКЦИЙ НА РАВНОМЕРНОМ ПРОСТРАНСТВЕ / Chekeev A.A., Kasymova T.D, Rakhmankulov B.Z. INVERSION-CLOSED ALGEBRAS OF FUNCTIONS ON A UNIFORM SPACE

Аскар кызы Л., Кененбаева Г.М. ЧИСЛЕННЫЕ ЭКСПЕРИМЕНТЫ ДЛЯ ВЫЯВЛЕНИЯ ЭФФЕКТА АНАЛИТИЧНОСТИ / Askar kyzy L., Kenenbaeva G.M. NUMERICAL EXPERIMENTS TO DETERMINE THE EFFECT ANALYTICITY

Билялова Л.Р., Ситшаева 3.3. О КЛАСТЕРИЗАЦИИ ТЕРРИТОРИИ РЕГИОНА ОТНОСИТЕЛЬНО ПОЛИГОНОВ ТКО / Bilyalova L.R., Sitshaeva Z.Z. ON CLUSTERING THE REGION IN RELATION TO MSW LANDFILLS

ТЕХНИЧЕСКИЕ НАУКИ

Тажибаев К.T., Ормонов М.Ж. МЕТОД ОПРЕДЕЛЕНИЯ ХАРАКТЕРИСТИК УПРУГОСТИ ТВЕРДЫХ МАТЕРИАЛОВ / Tazhibayev K.T., Ormonov M.J. METHOD FOR DETERMINATION OF SOLID MATERIALS ELASTICITY CHARACTERISTICS 52

Акимова К.В. ФАКТОРЫ, ПОБУЖДАЮЩИЕ СТРАНЫ К СТРОИТЕЛЬСТВУ АТОМНЫХ ЭЛЕКТРОСТАНЦИЙ / Akimova K.V. ТНЕ 
FACTORS THAT MOTIVATE COUNTRIES TO BUILD NUCLEAR POWER PLANTS

ЭКОНОМИЧЕСКИЕ НАУКИ

Алексеенко И.В., Старовойтова А.А. СТРУКТУРА РЫНКА ФИТНЕСУСЛУГ В ОМСКЕ / Alekseenko I.V., Starovoytova A.A. MARKET STRUCTURE OF FITNESS SERVICES IN OMSK

Исхакова А.Р., Иванов А.В. ПРОБЛЕМАТИКА ПЕРЕВОДА КОММЕРЧЕСКОГО БАНКА НА ДИСТАНЦИОННОЕ ОБСЛУЖИВАНИЕ КЛИЕНТОВ / Ishakova A.R., Ivanov A.V. PROBLEMS OF TRANSLATION OF THE COMMERCIAL BANK REMOTE CUSTOMER SERVICE 66

ФИЛОЛОГИЧЕСКИЕ НАУКИ 71

Жусуева С.К. ОБЩНОСТЬ И ТОЖДЕСТВО ЖАНРА ОЧЕРК С PACCKA3OM / Jusueva S.K. GENERALITY AND IDENTITY OF ESSAY GENRE WITH STORY. 71

ЮРИДИЧЕСКИЕ НАУКИ. 75

Ботобаев А.А. СИСТЕМА ГОСУДАРСТВЕННОГО И ОБЩЕСТВЕННОГО ПРОТИВОДЕЙСТВИЯ НЕЗАКОННОМУ ОБОРОТУ НАРКОТИЧЕСКИХ СРЕДСТВ В КЫРГЫЗСКОЙ РЕСПУБЛИКЕ / Botobaev A.A. ТНЕ SYSTЕМ OF STATE AND PUBLIC COUNTERACION TO ILLEGAL TURNOVER OF GRUGS IN THE KYRGYZ REPUBLIC .

Ботобаев A.A. ХАРАКТЕРИСТИКА НАРКОСИТУАЦИИ В КЫРГЫЗСТАНЕ НА COВРЕМЕННОМ ЭТАПЕ / Botobaev A.A. CHARACTERISTICS OF THE DRUG SITUATION IN KYRGYZSTAN AT THE PRESENT STAGE 79

ПЕДАГОГИЧЕСКИЕ НАУКИ 85

Антонина Л.В., Юферова Л.В. ИЗ ПРАКТИКИ ПРИМЕНЕНИЯ ПРОЕКТНЫХ ТЕХНОЛОГИЙ ПРИ ОРГАНИЗАЦИИ АТТЕСТАЦИИ СТУДЕНТОВ ПО ДИСЦИПЛИНЕ «ОСНОВЫ БРЕНДИНГА» / Antonina L.V., Yuferova L.V. OF PRACTICAL APPLICATION DESIGN TECHNOLOGY FOR CERTIFICATION TO THE STUDENTS ON THE DISCIPLINE "FUNDAMENTALS OF BRANDING". 85

Дащенко С.Н. ЦЕННОСТНО-СМЫСЛОВЫЕ ОРИЕНТИРЫ КАК ФАКТОР МОТИВАЦИИ В ДОПОЛНИТЕЛЬНОМ ОБРАЗОВАНИИ / Dashchenko S.N. VALUE AND SENSE OBJECTIVES (OF LEARNING) AS A FACTOR FOR MOTIVATION IN ADDITIONAL EDUCATION

Жукова В.И., Федоров А.С. КОММУНИКАТИВНАЯ КОМПЕТЕНЦИЯ КАК ДЕЙСТВЕННЫЙ ФАКТОР ПРОФЕССИОНАЛЬНОГО САМООПРЕДЕЛЕНИЯ / Zhukova V.I., Fedorov A.S. COMMUNICATIVE COMPETENCE, AS AN IMPORTANT FACTOR OF PROFESSIONAL SELFDETERMINATION

МЕДИЦИНСКИЕ НАУКИ.

Керменбаева А.Ж. КЛИНИЧЕСКИЙ УСПЕХ ЛЕЧЕНИЯ ТРУБНОПЕРИТОНЕАЛЬНОЙ ФОРМЫ БЕСПЛОДИЯ У ЖЕНЩИН РЕПРОДУКТИВНОГО ВОЗРАСТА ЛАПАРОСКОПИЧЕСКИМ ДОСТУПОМ / Kermenbaeva A.J. THE CLINICAL SUCCESS OF 
TREATMENT TUBE-PERITONEAL FORMS OF INFERTILITY IN WOMEN OF REPRODUCTIVE AGE LAPAROSCOPIC ACCESS 94

Човдурбаев Н.Ж. ЭПИДЕМИОЛОГИЯ И ПАТОГЕНЕЗ ТУБЕРКУЛЕЗА ПЕРИФЕРИЧЕСКИХ ЛИМФАТИЧЕСКИХ УЗЛОВ (ОБЗОР ЛИТЕРАТУРЫ) / Chovdurbaev N.Zh. EPIDEMIOLOGY AND PATHOGENESIS OF TUBERCULOSIS OF PERIPHERAL LYMPH NODES (LITERATURE REVIEW) 98

ИСКУССТВОВЕДЕНИЕ 103

Мирпаязов Б.А. ВОПРОС ВЫБОРА ПРОФЕССИИ ДЛЯ БУДУЩЕГО ПОКОЛЕНИЯ - ТРЕБОВАНИЕ ВРЕМЕНИ / Mirpayazov B.A. QUESTION OF THE CHOICE TO PROFESSIONS FOR FUTURE GENERATION - A REQUIREMENT OF TIME 103

АРХИТЕКТУРА 107

Boychenko K.V. KINETIC BEHAVIOR OF INTERACTIVE ARCHITECTURE / Бойченко К.В. КИНЕТИЧЕСКОЕ ПОВЕДЕНИЕ ИНТЕРАКТИВНОЙ АРХИТЕКТУРЫ ....

ПСИХОЛОГИЧЕСКИЕ НАУКИ 109

Шитова А.В. ВЛИЯНИЕ КЛИНИЧЕСКОЙ КАРТИНЫ ГИПОФИЗАРНОЙ НЕДОСТАТОЧНОСТИ НА ПОКАЗАТЕЛИ КАЧЕСТВА ЖИЗНИ И ВНУТРЕННЮЮ КАРТИНУ БОЛЕЗНИ ПАЦИЕНТОВ С ГИПОПИТУИТАРИЗМОМ / Shitova A.V. THE EFFECT OF PITUITARY HORMONE DEFICIENCY ON QUALITY OF LIFE AND ILLNESS PERCEPTION OF PATIENTS WITH HYPOPITUITARISM 109

НАУКИ О ЗЕМЛЕ

Кан М.Г., Кан И.М. ИССЛЕДОВАНИЕ О ХАРАКТЕРИСТИКАХ ФОРМИРОВАНИЯ СДВИГОВОГО РАЗРУШЕНИЯ В ТРЁХМЕРНОМ НАПРЯЖЕННОМ СОСТОЯНИИ / Kang M.G., Kang I.M. STUDY ON THE FORMATION OF SHEAR FRACTURE IN THREE-DIMENSIONAL STRESS SYSTEM. 


\title{
ФИЗИКО-МАТЕМАТИЧЕСКИЕ НАУКИ
}

ОБ ОДНОМ ЧАСТНОМ СЛУЧАЕ РЕШЕНИЯ ЗАДАЧИ ТРЕХ ТЕЛ Рубинштейн А.И. ${ }^{1}$, Городецкая Т.А. ${ }^{2}$, Серебренников П.С. ${ }^{3}$, Шипов Н.В. ${ }^{4}$, Шмаков A.B. ${ }^{5}$ Email: Rubinshtein1791@ scientifictext.ru

\footnotetext{
${ }^{1}$ Рубинштейн Александр Иосифович-доктор физико-математических наук, профессор;

${ }^{2}$ Городецкая Татьяна Александровна - стариий преподаватель;

${ }^{3}$ Серебренников Павел Семенович - кандидат физико-математических наук, доцент,

${ }^{4}$ Шипов Николай Викторович - кандидат физико-математических наук, доцент;

${ }^{5}$ Шмаков Андрей Вячеславович - кандидат физико-математических наук, доцент, кафедра высшей математики,

Мытищчинский филиал

Московский государственный технический университет им. Н.Э. Баумана, г. Мытищи
}

\begin{abstract}
Аннотация: в небесной механике - науке о движении небесных тел под действием сил различной физической природы - известна задача трех тел. Она заключается в описании относительного движения трёх материальных объектов, связанных друг с другом законом всемирного тяготения Ньютона. До сих пор общее решение задачи трех тел не получено. Проблема не имеет решения в виде однозначных аналитических функиий в общем случае, как, например, для двух тел. На сегодняшний день можно говорить лишь только о некоторых частных решениях (Лагранж, Эйлер), полученных при определенных заданных условиях специальных начальных скоростях и координатах объектов. В статье рассматривается элементарный случай решения ограниченной плоской круговой задачи трех тел, очевидным образом неустойчивого движения. Проводится элементарный вывод закона Всемирного тяготения из второго закона Ньютона и законов Кеплера.
\end{abstract}

Ключевые слова: задача трех тел, ограниченная плоская круговая задача, законы Ньютона, законы Кеплера.

\section{ONE PARTICULAR CASE OF SOLVING THE PROBLEM OF THREE BODIES}

\section{Rubinshtein A.I. ${ }^{1}$, Gorodetskaya N.A. ${ }^{2}$, Serebrennikov P.S. ${ }^{3}$, Shipov N.V. ${ }^{4}$, Shmakov A.V. ${ }^{5}$}

\author{
${ }^{I}$ Rubinshtein Aleksandr Iosifovich-DSc in physics and mathematics, Professor; \\ ${ }^{2}$ Gorodetskaya Tat'jana Aleksandrovna - senior teacher; \\ ${ }^{3}$ Serebrennikov Pavel Semenovich - PhD in physics and mathematics, Associate Professor; \\ ${ }^{4}$ Shipov Nikolaj Viktorovich-PhD in physics and mathematics, Associate Professor; \\ ${ }^{5}$ Shmakov Andrej Vyacheslavovich - PhD in physics and mathematics, Associate Professor, \\ HIGH MATHEMATICS DEPARTMENT, \\ MYTISHCHI BRANCH OF N.E.BAUMAN MOSCOW STATE TECHNICAL UNIVERSITY, MYTISHCHI
}

\begin{abstract}
: in celestial mechanics, the science of the motion of celestial bodies under the action of forces of different physical nature - there is the famous problem of three bodies. It is the description of relative motion of three material objects in relation to each under the Newtonian law of gravitation. Until now, the general solution of the problem of three bodies is not received. The problem has no solution in the form of simple analytical functions in the general case, as, for example, for two bodies. Today we can speak only about certain special solutions (Lagrange, Euler), obtained for certain specified conditions of special initial velocities and coordinates of objects. The article considers the elementary solution of the restricted planar circular three-body problem, which one is obviously unstable motion. It is given an elementary derivation of the law of universal gravitation from Newton's second law and Kepler's laws.
\end{abstract}

Keywords: the problem of three bodies, restricted planar circular problem, Newton's laws, Kepler's laws. 
Важнейшей задачей небесной механики является задача движения трех точечных масс, между любыми двумя из которых действует сила, определяемая законом всемирного тяготения Ньютона (1687)

$$
\bar{F}=k \cdot \frac{m_{1} m_{2}}{R^{3}} \cdot \bar{R},
$$

где $m_{1}, m_{2}$ - точечные массы, $\bar{R}$ - вектор, соединяющий эти массы, $R=|\bar{R}|, k-$ постоянная всемирного тяготения.

Как известно, эта задача неразрешима - в конце 19 века Брунс доказал, что общее решение задачи трех тел нельзя выразить через алгебраические функции, а Пуанкаре - через однозначные трансцендентные функции координат и скоростей тел. В 1912 году финский математик К. Зундман получил решение в виде ряда разложения по степеням некоторой функции. Но этот ряд столь медленно сходится, что получить ответ с требуемой для астрономических приложений точностью на сколь угодно большом промежутке времени невозможно даже с использованием современных компьютеров.

Вместе с тем еще 1772 г. Лагранж указал на существование двух типов частных решений задачи трех тел. В первом случае тела находятся в вершинах равностороннего треугольника, длина стороны которого изменяется по законам И. Кеплера и треугольники вращаются в одной плоскости вокруг общего центра масс. Второй частный случай относится к тому, когда все три тела постоянно находятся на прямой, вращающейся вокруг центра масс по законам Кеплера. На подобное решение указал ранее (в 1767 году) Л. Эйлер. Такое движение оказывается неустойчивым - конфигурация распадается при изменении параметров.

В 1907 году астрономы в Гейдельберге обнаружили один, а потом еще восемь астероидов вблизи орбиты Юпитера (впереди него), положение которых с Юпитером и Солнцем образует равносторонний треугольник. Эти девять астероидов получили греческие имена участников троянской войны. Были обнаружены и пять астероидов, «отстающих» на $60^{\circ}$ от Юпитера, с такими же свойствами орбит, названные именами защитников Трои. Движения «греков» и «троянцев» устойчивы (обо всем этом можно узнать из статьи [1]).

Рассмотрим еще одно (неустойчивое) решение плоской круговой задачи. Пусть точечные массы $m_{2}$ и $m_{3}$ движутся по плоской круговой орбите радиуса $\mathrm{R}$ вокруг массы $m_{1}$, и расстояние между $m_{2}$ и $m_{3}$ остается постоянным, равным $r$. При этом $r$ столь мало по сравнению с $\mathrm{R}$, а масса $m_{2}$ столь велика, что влиянием массы $m_{1}$ на малую массу $m_{3}$ можно пренебречь. Так как $m_{2}$ и $m_{3}$ постоянно находятся на одной окружности радиуса $\mathrm{R}$ с центром в точке $m_{1}$, то круговое вращение по закону всемирного тяготения массы $m_{3}$ вокруг массы $m_{2}$ имеет тот же период, что и вращение $m_{2}$ (и $\left.m_{3}\right)$ вокруг $m_{1}$.

Если $v_{1}$ и $v_{2}$-скорости движения масс $m_{2}$ и $m_{3}$ вокруг своих центров, то по второму закону Ньютона и закону всемирного тяготения получим

$$
\begin{aligned}
& m_{2} \cdot \frac{v_{2}^{2}}{R}=k \cdot \frac{m_{1} m_{2}}{R^{2}} \Rightarrow \frac{4 \pi^{2} \cdot R^{2}}{T^{2}}=k \cdot \frac{m_{1}}{R} \Rightarrow T^{2}=\frac{4 \pi^{2} \cdot R^{3}}{k \cdot m_{1}} ; \\
& m_{3} \cdot \frac{v_{3}^{2}}{r}=k \cdot \frac{m_{2} m_{3}}{r^{2}} \Rightarrow \frac{4 \pi^{2} \cdot r^{2}}{T^{2}}=k \cdot \frac{m_{2}}{r} \Rightarrow T^{2}=\frac{4 \pi^{2} \cdot r^{3}}{k \cdot m_{2}}
\end{aligned}
$$

Откуда получаем:

$$
\text { или }\left(\frac{R}{r}\right)^{3}=\frac{m_{1}}{m_{2}} \quad \Leftrightarrow \quad r=R \cdot \sqrt[3]{\frac{m_{2}}{m_{1}}}
$$

Очевидно, что движение неустойчиво: малейшее изменение массы $m_{2}$ ведет к изменению орбиты массы $m_{3}$. С материалом по данной тематике можно ознакомиться в следующих литературных источниках: [2] - [8]. 
В завершение приведем элементарный вывод закона Всемирного тяготения из второго закона Ньютона и законов Кеплера. Если имеет место круговое движение материальной точки с постоянной угловой скоростью, то есть, если

$$
\begin{gathered}
\left\{\begin{array}{l}
x=R \cos \frac{2 \pi}{T} \cdot t \\
y=R \sin \frac{2 \pi}{T} \cdot t
\end{array} \quad 0 \leq t \leq T, \quad\right. \text { (5) } \\
\bar{v}=\left(-\frac{2 \pi}{T} R \cdot \sin \frac{2 \pi}{T} t ; \frac{2 \pi}{T} R \cdot \cos \frac{2 \pi}{T} t\right), \text { имеем } \quad \text { (6) } \\
\frac{d}{d t}(m \cdot \bar{v})=m \cdot \frac{d \bar{v}}{d t}=m \cdot R \cdot \frac{d}{d t}\left(-\frac{2 \pi}{T} \sin \frac{2 \pi}{T} t ; \frac{2 \pi}{T} \cos \frac{2 \pi}{T} \cdot t\right)=-\frac{4 \pi^{2}}{T^{2}} m \cdot\left(R \cos \frac{2 \pi}{T} t ; R \sin \frac{2 \pi}{T} t\right)= \\
=-\frac{4 \pi^{2}}{T^{2}} m \cdot \bar{R}=\bar{F}(t) \quad \text { учетом, того, }
\end{gathered}
$$

По третьему закону Кеплера

$$
\frac{R^{3}}{T^{2}}=C
$$

Следовательно,

$$
\bar{F}(t)=-\frac{4 \pi^{2}}{T^{2}} m \cdot \bar{R}=-4 \pi^{2} m \cdot \frac{C}{R^{3}} \bar{R}=-4 \pi^{2} C \cdot m \cdot \frac{\bar{R}}{R^{3}}
$$

Но в силу относительности движения можно считать, что центр окружности (масса $\mathrm{M}$ ) движется с постоянной угловой скоростью $2 \pi / \mathrm{T}$ вокруг фиксированной точки (масса $m$ ) на окружности, то есть

Отсюда

$$
C=M \quad(10)
$$

$$
\bar{F}(t)=-\left(4 \pi^{2} \lambda\right) \cdot m \cdot M \frac{\bar{R}}{R^{3}}=-k \cdot m \cdot M \frac{\bar{R}}{R^{3}},
$$

что и является законом всемирного тяготения.

Из полученного соотношения следует, что сила

$$
F=|\bar{F}(t)| \text { пропорциональна } \frac{m \cdot M}{R^{2}} .
$$

О подобном говорили Коперник, Галилей, Галлей, Гук.

\section{Список литературы / References}

1. Маркеев А.П. О задаче трех тел и ее точных решениях, Империя математики // Физикоматематический журнал для юношества. № 1, 2000. Ижевск, Удмуртский Университет. Стр. 40-54.

2. Дубошин Г.Н. Небесная механика: Аналитические и качественные методы // М.: Наука, 1964.

3. Демин В.Г. Судьба Солнечной системы // М.: Наука, 1975.

4. Парс Л. Аналитическая динамика // М.: Наука, 1971.

5. Маркеев А.П. Точки либрации в небесной механике и космодинамике // М.: Наука, 1978.

6. Алексеев В.М. Обмен и захват в задачах трех тел // ДАН СССР. 108. № 4, 1956. С. 599-602.

7. Алексеев B.M. Новые примеры захвата в задачах трех тел // Астрономический журнал. 39. № 4, 1962. С. 724-735.

8. Арнольд В.И. О классической теории возмущений в проблеме устойчивости планетных систем // ДАН СССР. 145. № 3, 1962. С. 487-490. 


\title{
О ДВУХ ЭЛЕМЕНТАРНЫХ ТЕОРЕТИКО-ЧИСЛОВЫХ ЗАДАЧАХ Рубинштейн А.И. ${ }^{1}$, Городецкая Т.А. ${ }^{2}$, Серебренников П.С. ${ }^{3}$, Шипов Н.В. ${ }^{4}$, Шмаков A.B. ${ }^{5}$ Email: Rubinshtein1791@ scientifictext.ru
}

\author{
${ }^{1}$ Рубинштейн Александр Иосифович - доктор физико-математических наук, профессор; \\ ${ }^{2}$ Городеикая Татьяна Александровна - стариий преподаватель; \\ ${ }^{3}$ Серебренников Павел Семенович - кандидат физико-математических наук, дочент; \\ ${ }^{4}$ Шипов Николай Викторович - кандидат физико-математических наук, доцент; \\ ${ }^{5}$ Шмаков Андрей Вячеславович - кандидат физико-математических наук, доцент, \\ кафедра высшей математики, \\ Мытищинский филиал \\ Московский государственный технический университет им. Н.Э. Баумана, г. Мытищи
}

\begin{abstract}
Аннотация: рассматриваются две элементарные теоретико-числовые задачи: 1) найти разложение в непрерывную дробь квадратного корня из любого натурального числа, 2) найти все коэффициенты приведенного кубического уравнения, при которых для нахождения одного из его корней используются только операчии сложения, вычитания, умножения и извлечения кубического корня. Как известно, любое раџиональное число представляется конечной непрерывной дробью, а любое иррациональное - бесконечной непрерывной дробью. Оказывается, что непрерывная дробь наилучшим образом приближает число с помощью рациональных чисел.
\end{abstract}

Ключевые слова: непрерывная дробь, диофантово уравнение, кубическое уравнение, пифагорова тройка.

\section{TWO ELEMENTARY NUMBER-THEORETIC PROBLEMS Rubinshtein A.I. ${ }^{1}$, Gorodetskaya N.A. ${ }^{2}$, Serebrennikov P.S. ${ }^{3}$, Shipov N.V. ${ }^{4}$, Shmakov A.V. ${ }^{5}$}

\author{
${ }^{1}$ Rubinshtein Aleksandr Iosifovich - DSc in physics and mathematics, Professor; \\ ${ }^{2}$ Gorodetskaya Tat'jana Aleksandrovna - senior teacher; \\ ${ }^{3}$ Serebrennikov Pavel Semenovich $-P h D$ in physics and mathematics, Associate Professor; \\ ${ }^{4}$ Shipov Nikolaj Viktorovich-PhD in physics and mathematics, Associate Professor; \\ ${ }^{5}$ Shmakov Andrej Vyacheslavovich - PhD in physics and mathematics, Associate Professor, \\ HIGH MATHEMATICS DEPARTMENT, \\ MYTISHCHI BRANCH OF N.E.BAUMAN MOSCOW STATE TECHNICAL UNIVERSITY, MYTISHCHI
}

\begin{abstract}
: we consider two elementary number-theoretic problems: 1) find the decomposition in continued fraction of the square root of any natural number, 2) find all the coefficients of the given cubic equation, in order to find one of the roots, the only operations used are addition, subtraction, multiplication and evolution of cube root. As one knows, any rational number is represented by finite continued fraction, and every irrational - by infinite continued fraction. It turns out that the continued fraction best approximates the number using rational numbers.
\end{abstract}

Keywords: continued fraction, Diophantine equation, cubic equation, Pythagorean triplets.

УДК 511.4

С четвертого века до нашей эры известен алгоритм Евклида нахождения наибольшего общего делителя двух натуральных чисел $m$ и $n$, который в случае $m>n$ представляет цепочку равенств

$m=q_{1} \cdot n+r_{1}$, где $0 \leq r_{1}<n ; n=q_{2} \cdot r_{1}+r_{2}$, где $0 \leq r_{2}<r_{1}, \ldots, r_{s-2}=q_{s} \cdot r_{s-1}+0$, то есть $r_{s}=0$

Эту цепочку можно записать в виде 


$$
\begin{aligned}
& m=q_{1}+\frac{1}{q_{2}+\frac{1}{q_{3}+} \cdot} \\
& +\frac{1}{q_{s-1}+\frac{1}{q_{s}}}
\end{aligned}
$$

Это представление $m=\left[q_{1}, q_{2}, \ldots, q_{s-1}, q_{s}\right]$ называется конечной непрерывной (или цепной) дробью. Очевидно, что в виде непрерывной дроби, где «неполные частные» $q_{i}$ уже не обязательно натуральные, а любые действительные числа, можно представлять уже произвольные числа.

Вообще непрерывная числовая дробь может быть бесконечной

$$
a_{1}+\frac{1}{a_{2}+\frac{1}{a_{3}+}}
$$

и обычно считают $a_{2}, a_{3}, \ldots$ положительными числами, а $a_{1}$ - любым числом (см. [1]). О свойствах непрерывных дробей можно узнать из многих популярных издании: [1] - [2].

Любое рациональное число представляется конечной непрерывной дробью, а любое иррациональное - бесконечной непрерывной дробью.

Оказывается (см. [2], стр. 32), что непрерывная дробь наилучшим образом приближает число с помощью рациональных чисел. Оказывается (см. [1], стр. 64), что условие

$$
\left|a_{k}\right| \leq C \text { при всех } \mathrm{k}=1,2, \ldots
$$

равносильно тому, что $x=\left[a_{1}, a_{2}, a_{3} \ldots\right]$ есть корень квадратного уравнения с целыми (равносильно, рациональными) коэффициентами.

Найдем разложение в непрерывную дробь $\sqrt{m}, m \neq n^{2}$. Очевидно, что следует искать разложение $\sqrt{n^{2}+k}$, где $0<k<2 n+1$.

Имеем

$$
\begin{gathered}
\sqrt{n^{2}+k}=n+\left(\sqrt{n^{2}+k}-n\right)=n+\frac{k}{\sqrt{n^{2}+k}+n}=n+\frac{k}{2 n+\left(\sqrt{n^{2}+k}-n\right)}=n+\frac{1}{\frac{2 n}{k}+\frac{\sqrt{n^{2}+k}-n}{k}}= \\
=n+\frac{1}{\frac{2 n}{k}+\frac{1}{\sqrt{n^{2}+k}+n}}=n+\frac{1}{\frac{2 n}{k}+\frac{1}{2 n+\left(\sqrt{n^{2}+k}-n\right)}}=n+\frac{1}{\frac{2 n}{k}+\frac{1}{2 n+\frac{k}{\sqrt{n^{2}+k}+n}}}=
\end{gathered}
$$$$
=n+\frac{1}{\frac{2 n}{k}+\frac{1}{2 n+\frac{k}{2 n+\left(\sqrt{n^{2}+k}-n\right)}}}=n+\frac{1}{\frac{2 n}{k}+\frac{1}{2 n+\frac{1}{\frac{2 n}{k}+\frac{1}{2 n+\left(\sqrt{n^{2}+k}-n\right)}}}}=\ldots
$$

Отсюда

$$
\sqrt{n^{2}+k}=\left[n, \frac{2 n}{k}, 2 n, \frac{2 n}{k}, 2 n, \ldots\right] .
$$


Значит для $\sqrt{n^{2}+k}$ числа $0<a_{i} \leq 2 n$ (при $0<k<2 n+1$ ).

В частности

$$
\sqrt{n^{2}+n}=[n, 2,2 n, 2,2 n, \ldots]
$$

Как хорошо известно, общее уравнение третьей степени легко сводится к виду

$$
x^{3}+p x+q=0
$$

а решением этого уравнения является (при $\left(\frac{q}{2}\right)^{2}+\left(\frac{p}{3}\right)^{3}>0$ ) число

$$
x=\sqrt[3]{-\frac{q}{2}+\sqrt{\left(\frac{q}{2}\right)^{2}+\left(\frac{p}{3}\right)^{3}}}-\sqrt[3]{\frac{q}{2}+\sqrt{\left(\frac{q}{2}\right)^{2}+\left(\frac{p}{3}\right)^{3}}}
$$

Если потребовать, чтобы $\frac{q}{2}$ и $\frac{p}{3}$ были целыми, то условие $\sqrt{\left(\frac{q}{2}\right)^{2}+\left(\frac{p}{3}\right)^{3}}$ - целое число, приводит к диофантову уравнению

$$
r^{2}+s^{3}=n^{2}
$$

Решение этого уравнения легко находится из тождества

$$
\left(u\left(u^{2}+3 v^{2}\right)\right)^{2}+\left(v^{2}-u^{2}\right)^{3}=\left(v\left(3 u^{2}+v^{2}\right)\right)^{3}
$$

(см. например [5]).

Напомним, что все пифагоровы тройки находятся из тождества

$$
(u v)^{2}+\left(\frac{u^{2}-v^{2}}{2}\right)^{3}=\left(\frac{u^{2}+v^{2}}{2}\right)^{2}
$$

Но к решению уравнения $r^{2}+s^{3}=n^{2}$ можно подойти и иначе, не используя тождество Серпинского. Очевидно, что при всех $s=2,3, \ldots$

$$
r=\frac{s(s-1)}{2}, \quad s=s, \quad n=\frac{s(s+1)}{2}
$$

- его решение. Пусть

$$
s^{3}=p_{1}^{3}, p_{2}^{3}, \ldots \ldots ., p_{v}^{3}, \quad 1<p_{1} \leq p_{2} \leq \ldots \ldots p_{v} \text { - простые числа. }
$$

Если

$$
s^{3}=\sigma_{1} \cdot \sigma_{2} ; \sigma_{2}-\sigma_{1}=2 \ell
$$

(при нечетных s используем и представление $s^{3}=1 \cdot s^{3}$ ) легко убеждаемся, что

$$
\left(\frac{\sigma_{2}-\sigma_{1}}{2}\right)^{2}+s^{3}=\left(\frac{\sigma_{2}+\sigma_{1}}{2}\right)^{2}
$$

то есть все решения исследуемого диофантова уравнения получаем из соотношений

$$
s^{3}=\sigma_{1} \cdot \sigma_{2}, \frac{\sigma_{2}-\sigma_{1}}{2} \in N, \quad \frac{\sigma_{2}+\sigma_{1}}{2} \in N \text { (см. [6]). }
$$

\section{Список литературы / References}

1. Хинчин А.Я. Цепные дроби // ГИТТЛ. М.-Л., 1949.

2. Гельфонд А.О. Решение уравнений в целых числах // Популярные лекции по математике. Вып. 8. ГИТТЛ. М., 1956. 
3. Курант Р. Роббинс, Что такое математика? // МЦНМО, 2001.

4. Рубинштейн А.И. Связующая нить. Неизвестная математика // Дрофа. М., 2009.

5. Серпинский В. О решении уравнений в целых числах // Физматлит. М., 1961.

6. Рубинштейн А.И. О кубических уравнениях // Квант. № 2, 1998. 38-40.

\title{
ОБРАТНАЯ ЗАДАЧА ОПРЕДЕЛЕНИЯ ФУНКЦИИ ИСТОЧНИКА В ПСЕВДОПАРАБОЛИЧЕСКОМ УРАВНЕНИИ С ИНТЕГРАЛЬНЫМ ПЕРЕОПРЕДЕЛЕНИЕМ

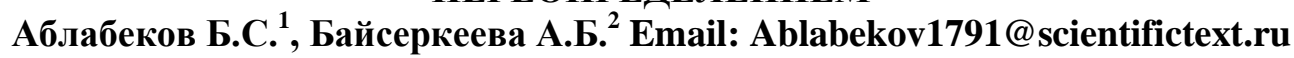

\author{
${ }^{1}$ Аблабеков Бактыбай Сапарбекович - доктор физико-математических наук, профессор, \\ кафедра прикладной математики, информатики и компьютерных технологий, \\ Кыргызский национальный университет им. Ж.Баласагына, г. Бинкек; \\ ${ }^{2}$ Байсеркеева Айнура Бектургановна - преподаватель, \\ кафедра теоретической и прикладной математики, \\ Иссык-Кульский государственный университет им. К. Тыныстанова, \\ г. Каракол, Кьргызская республика
}

\begin{abstract}
Аннотация: изучается обратная задача определения источника, зависящего от времени, для многомерного псевдопараболического уравнения. Дополнительная информация задаётся в виде интегрального переопределения с некоторой заданной весовой функиией. При решении исходной задачи осуществляется переход от обратной задачи к некоторой вспомогательной прямой задаче. Получено достаточное условие однозначной разрешимости рассматриваемой задачи. При доказательстве разрешимости задачи используется метод интегральных уравнений. Существование и единственность интегрального уравнения доказаны с помощью приниипа сжатых отображений.
\end{abstract}

Ключевые слова: обратная задача, псевдопараболические уравнения, интегральное переопределение.

\section{INVERSE PROBLEM OF DETERMINING THE SOURCE FUNCTION IN PSEUDOPARABOLIC EQUATIONS WITH INTEGRAL OVER DETERMINATION

\author{
Ablabekov B.S. ${ }^{1}$, Baiserkeeva A.B. ${ }^{2}$
}

\author{
${ }^{I}$ Ablabekov Baktybai Saparbekovich - Doctor of physico-mathematical sciences, Professor, \\ DEPARTMENT OF APPLIED MATHEMATICS, INFORMATICS AND COMPUTER TECHNOLOGIES, \\ KYRGYZ NATIONAL UNIVERSITY OF JUSUP BALASAGYN, BISHKEK; \\ ${ }^{2}$ Baiserkeeva Ainura Bekturganovna - Lecturer, \\ DEPARTMENT OF THEORETICAL AND APPLIED MATHEMATICS, \\ ISSYK-KUL STATE UNIVERSITY OF KASIM TYNYSTANOV, \\ KARAKOL, REPUBLIC OF KYRGYZSTAN
}

\begin{abstract}
: studied the inverse problem of determining a source, depending on the time for the multidimensional pseudoparabolic equation. Additional information is given in form of an integral redefinition with a given weight function. To study solvability of the inverse problem, we realize a conversion from inverse problem to a some direct problem. We establish conditions for the existence and uniqueness of the classical solution of the problem considered. To prove solvability of the problem, we use the method of integral equations.

The existence and uniqueness of the integral equation are proved by means of the contraction mappings principle.
\end{abstract}

Keywords: inverse problem, pseudo-parabolic equations, integral redefinition.

УДК 517.946

Введение. Постановка задачи.

Под обратными задачами для дифференциальных уравнений будем понимать задачи определения коэффициентов, правой части, начальных или граничных условий по некоторой дополнительной информации о решении прямой задачи. Наиболее полное современное состояние теории обратных для дифференциальных уравнений с обширной библиографией 
отражены в монографиях $[1,2,4,10]$. Обратные задачи с интегральным переопределением для параболических и гиперболических уравнений второго порядка уравнений изучались в $[3-5,7$ - 8, 10], а для псевдопараболических уравнений при других предположениях на входные данные и другими методами изучены в работе [1].

Пусть $\Omega$ - ограниченная область в $R^{n}$ с гладкой границей $\partial \Omega \in C^{2}$, $\Omega_{T}=\Omega \times(0, T)$, где $T>0$ - цилиндр с боковой поверхностью $S_{T}=\partial \Omega \times[0, T]$.

Рассмотрим в области $\Omega_{T}$ обратную задачу определения пары функций $\left\{u(x, t) \in C^{1}\left(0, T ; L_{2}(\Omega)\right), \quad f(t) \in C[0, T]\right\} \quad$ в $\quad$ псевдопараболическом уравнении

$$
\begin{gathered}
u_{t}-\Delta_{x} u_{t}-\beta \Delta_{x} u+q(x, t) u=f(t) h(x, t)+g(x, t), \quad(x, t) \in \Omega_{T}, \\
u(x, 0)=\varphi(x), \quad x \in \bar{\Omega} \\
\left.u\right|_{S_{T}}=0, \\
\int_{\Omega} u(x, t) w(x) d x=\psi(t), \quad 0 \leq t \leq T
\end{gathered}
$$

где $q(x, t) \geq 0, \beta \geq 0$ - постоянные.

Условие (4) называется интегральным переопределением.

В настоящей работе установлены достаточные условия, при которых решение обратной задачи (1)-(3) существует и единственно.

2. Основной результат. Существование и единственность решения обратной задачи (1)-(3)

Докажем вспомогательную лемму.

Лемма 1. Пусть $u \in W_{2}^{2}(\Omega) \cap \stackrel{\circ}{W}_{2}(\Omega)$. Тогда существует обратный оператор $(I-\Delta)^{-1}$, причем

$$
\left\|(I-\Delta)^{-1}\right\|_{L_{2}(\Omega)} \leq \frac{1}{2} .
$$

Доказательство. Установим свойства обратимости оператора $I-\Delta$. Для этого достаточно показать его строгую положительность. Действительно, пусть $u \in W_{2}^{2}(\Omega) \cap \stackrel{1}{W}_{2}(\Omega)$. Тогда

$$
\begin{aligned}
& \left.<(I-\Delta) u, u>=\int_{\Omega} u^{2}(x, t) d x-\int_{\Omega} u(x, t) \Delta u(x, t)\right) d x= \\
& =\int_{\Omega} u^{2}(x, t) d x+\int_{\Omega}\left|\nabla_{x} u(x, t)\right|^{2} d x=\left\|\nabla_{x} u\right\|_{L_{2}(\Omega)}^{2}+\|u\|_{L_{2}(\Omega)}^{2}
\end{aligned}
$$

Отсюда, после применения неравенство Фридрихса, получаем

$$
\|(I-\Delta) u\|_{L_{2}(\Omega)} \cdot\|u\|_{L_{2}(\Omega)} \geq|((I-\Delta) u, u)| \geq 2 \mid\|u\|_{L_{2}(\Omega)}^{2} \cdot
$$

Так как оператор $I-\Delta$ является положительно определенной, то отсюда и в силу известной теоремы (например [9]), следует заключение леммы.

Теорема 1. Пусть $w(x) \in W_{2}^{2}(\Omega) \cap W_{2}^{1}(\Omega), \quad \psi(t) \in C^{1}([0, T]), \quad \varphi(x) \in W_{2}^{2}(\Omega)$, $h(x, t), g(x, t) \in C\left(0, T ; L_{2}(\Omega)\right)$ и $|<h, w>| \geq \delta>0$ при всех $t \in[0, T]$, 
$\frac{1}{2}\left[\delta^{-2}\|h\|_{C\left(0, T ; L_{2}(\Omega)\right)}\|\Delta w\|_{L_{2}(\Omega)}^{2}+1\right]<1$. Кроме того, для функций $\varphi(x), \psi(t)$ выполнены условия согласования $\int_{\Omega} \varphi(x) w(x) d x=\psi(0)$. Тогда обратная задача (1)-(4) имеет единственное решение в классе $u \in C^{1}\left(0, T ; L_{2}(\Omega)\right), f \in C[0, T]$.

Доказательство. Заметим что, так как задача (1)-(4) линейна, то ее решение можно искать в виде

$$
\{u(x, t), f(t)\}=\{z(x, t), f(t)\}+\{v(x, t), 0\}
$$

где $v(x, t)$ - решение в $\Omega_{T}$ прямой задачи

$$
\begin{gathered}
v_{t}(x, t)-\Delta v_{t}(x, t)-\beta \Delta v(x, t)=g(x, t), \quad(x, t) \in \Omega_{T}, \\
v(x, 0)=\varphi(x), \quad x \in \bar{\Omega}, \\
\left.v\right|_{S_{T}}=0,
\end{gathered}
$$

а пара $\{z(x, t), f(t)\}$ - решение в $\Omega_{T}$ обратной задачи:

$$
\begin{gathered}
z_{t}(x, t)-\Delta z_{t}(x, t)-\beta \Delta z(x, t)=f(t) h(x, t), \quad(x, t) \in \Omega_{T}, \\
z(x, 0)=0, \quad x \in \bar{\Omega}, \quad(10) \\
\left.z\right|_{S_{T}}=0, \quad(11) \\
\int_{\Omega} z(x, t) w(x) d x=\tilde{\psi}(t) \equiv \psi(t)-\int_{\Omega} v(x, t) w(x) d x, \quad 0 \leq t \leq T .
\end{gathered}
$$

Из теоремы о существовании и единственности решения задачи (6) - (8) следует, что для доказательства теоремы 1 достаточно доказать существование и единственность определения пары функций $\{z(x, t), f(t)\}$ из условий (9) - (12).

Поэтому, не ограничивая общности в задаче (1) - (4), положим, что $\varphi(x)=g(x, t)=0$.

Умножая обе части (9) скалярно на $w(x)$ в $L_{2}(\Omega)$, получим

$$
\left(u_{t}-\Delta u_{t}-\beta \Delta u, w(x)\right)=f(t)(h(x, t), w(x)) .
$$

Так как

$$
\begin{aligned}
& \left(u_{t}, w\right)=\frac{d}{d t}(u, w)=\psi^{\prime}(t) \\
& -\left(\Delta\left(u_{t}+\beta u\right), w\right)=-\left(u_{t}+\beta u, \Delta w\right)
\end{aligned}
$$

то из (1) получим

$$
f(t)=\left(-\int_{\Omega}\left(u_{t}+\beta u\right)(s, t) \Delta w(s) d s+\psi^{\prime}(t)\right) / h_{0}(t)
$$

где

$$
h_{0}(t)=\int_{\Omega} h(s, t) w(s) d s .
$$

Подставляя (15) в (1), получим

$$
u_{t}-\Delta\left(u_{t}+\beta u\right)=A\left(u_{t}+\beta u\right)+\tilde{f}(x, t)
$$

где 


$$
\begin{aligned}
& A v=\int_{\Omega} K(x, s, t) v(s, t) d s, \\
& K(x, s, t)=-h(x, t) \Delta w(s) / h_{0}(t), \\
& \widetilde{f}(x, t)=h(x, t) \psi^{\prime}(t) / h_{0}(t) .
\end{aligned}
$$

С помощью оператора $\Delta$, уравнение (16) можно переписать в виде

$$
\frac{d}{d t}(I-\Delta u)-\beta \Delta u=A\left(u_{t}+\beta u\right)+\tilde{f}(x, t),
$$

где операторы $\Delta$ и $\frac{d}{d t}$ коммутируют между собой. Поэтому уравнение (17) можно переписать в виде

$$
(I-\Delta u)\left(\frac{d u}{d t}\right)-\beta \Delta u=A\left(u_{t}+\beta u\right)+\tilde{f}(x, t) .
$$

В силу обратимости оператора $(I-\Delta)^{-1}=G$, уравнение (18) можно переписать в виде операторного уравнения

$$
\frac{d u}{d t}-G(\beta \Delta u)=G\left(A\left(u_{t}+\beta u\right)\right)+G \tilde{f}(x, t) .
$$

Учитывая, что $-G(\beta \Delta u)=-\beta G(\Delta u-u+u)=\beta u-\beta G u, \quad$ заменим последнее уравнение к эквивалентному уравнению

$$
\frac{d u}{d t}+\beta u=\beta G u+G\left(A\left(u_{t}+\beta u\right)\right)+G \tilde{f}(x, t) .
$$

Сделав обозначения $u_{t}+\beta u=\vartheta_{\text {и вводя оператор }}$

$$
B \vartheta=\int_{0}^{t} e^{-\beta(t-\tau)} \vartheta(x, \tau) d \tau+e^{-\beta t} u_{0}(x),
$$

из задачи (19),(2),(3) переходим к операторному уравнению

$$
\vartheta=G B \vartheta+G A \vartheta+F
$$

где

$$
F(x, t)=G \tilde{f}+e^{-\beta t} u_{0}(x) .
$$

Докажем, что $\|G B+G A\|_{C\left(0, T ; L_{2}(\Omega)\right)}<1$. Так как

$$
|A \vartheta|^{2}=\left|\int_{\Omega} K(x, s, t) \vartheta(s, t) d s\right|^{2} \leq \int_{\Omega}|K(x, s, t)|^{2} d s \cdot \int_{\Omega}|\vartheta(s, t)|^{2} d s,
$$

TO

$\|A \vartheta\|_{C\left(0, T ; L_{2}(\Omega)\right)}^{2} \leq\|\vartheta\|_{C\left(0, T ; L_{2}(\Omega)\right)} \cdot \delta^{-2}\|h\|_{C\left(0, T ; L_{2}(\Omega)\right)}\|\Delta w\|_{L_{2}(\Omega)}^{2}$.

Проводя аналогичную оценку для оператора $B$, получим

$\|B \vartheta\|_{C\left(0, T ; L_{2}(\Omega)\right)} \leq\|\vartheta\|_{C\left(0, T ; L_{2}(\Omega)\right)}$.

Тогда в силу леммы 1 имеем 


$$
\|(G B+G A) \vartheta\|_{C\left(0, T ; L_{2}(\Omega)\right)} \leq \frac{1}{2}\left[\delta^{-2}\|h\|_{C\left(0, T ; L_{2}(\Omega)\right)}\|\Delta w\|_{L_{2}(\Omega)}^{2}+1\right] \mid \vartheta\left\|_{C\left(0, T ; L_{2}(\Omega)\right)}<\right\| \vartheta \|_{C\left(0, T ; L_{2}(\Omega)\right)},
$$

т.е. $\|G\|<1$. Это условие гарантирует однозначную разрешимость операторного уравнения (19). Тогда из равенства $u_{t}+\beta u=\vartheta$ однозначно находим функции $u(x, t)$. Следовательно, по формуле (15) единственным образом определим функцию $f(t)$.

Докажем, что решение задачи единственно. Предположим противное. Тогда, повторяя вывод операторного уравнения (19) $\vartheta=\vartheta_{1}-\vartheta_{2}$, получаем, что $\vartheta$ удовлетворяет однородному уравнению.

В силу единственности операторного уравнения (19) получим $\vartheta=0$. Следовательно, $u=0$ и $f=0$. Теорема 1 доказана.

\section{Список литературы / References}

1. Аблабеков Б.С. Обратные задачи для дифференциальных уравнений третьего порядка. LAP.LAMBERT Academic Publishing, 2011.291 c.

2. Кабанихин С.И. Обратные и некорректные задачи. Новосибирск: Сиб. науч. изд-во, 2009. $457 \mathrm{c}$.

3. Камынин В.Л. Об обратной задаче определения правой части в параболическом уравнении с условием интегрального переопределения // Мат. Заметки, 2005. Т. 77. Вып. 4. С. 522-534.

4. Прилепко А.И., Костин А.Б. О некоторых обратных задачах для параболических уравнений с финальным и интегральным переопределением // Мат. сб., 1992. Т. 183. № 4. С. 49-68.

5. Прилепко А.И., Ткаченко Д.С. Фредгольмовость и корректная разрешимость обратной задачи об источнике с интегральным переопределением // Ж. вычисл. матем. и матем. физ., 2003. Том 43. № 9. 1392-1401.

6. Романов В.Г. Обратные задачи математической физики. М.: Наука, 1984. 254 с.

7. Сафиуллова P.P. О разрешимости линейной обратной задачи нахождения правой части составного вида в гиперболическом уравнении // Вестник Южно-уральского университета. Серия: математическое моделирование и программирование, 2009. № 37 (170). С. 93-105.

8. Павлов С.С. Обратная задача восстановления внешнего воздействия в многомерном волновом уравнении с интегральным переопределением // Мат. заметки СВФУ, 2011. Т. 18. № 1. C. 81-93.

9. Треногин В.А. Функциональный анализ. М.:Наука, 1980. 495 с.

10. Prilepko A.I., Orlovsky D.G., Vasin U.A. Methods for solving inverse problems in mathematical fhysics. New York; Basel: Marcelker, 1999. 709 p. 


\title{
ЗАДАЧА КОШИ ДЛЯ СИНГУЛЯРНО-ВОЗМУЩЕННОГО ИНТЕГРО- ДИФФЕРЕНЦИАЛЬНОГО УРАВНЕНИЯ С ДВУМЯ МАЛЫМИ ПАРАМЕТРАМИ \\ Омуров Т.Д. ${ }^{1}$, Алиева А.P. ${ }^{2}$ Email: Omurov1791@ scientifictext.ru
}

\author{
${ }^{I}$ Омуров Таалайбек Дардаылович - доктор физико-математических наук, профессор, \\ кафедра математического анализа и дифференциальных уравнений, \\ факультет математики, информатики, \\ Кыргызский национальный университет им. Жусупа Баласагына; \\ ${ }^{2}$ Алиева Айнур Рабатовна - стариий научный сотрудник, \\ лаборатория прикладной математики и информатики, \\ Институт теоретической и прикладной математики Наџиональной академии наук \\ Кыргызской Республики, \\ 2. Биикек, Кыргызская Республика
}

\begin{abstract}
Аннотация: в области сингулярно-возмущенных задач уравнения с двумя и более малыми параметрами были исследованы в работах [6, 10] и др., причем вопросы устойчивости или условной устойчивости решения имеют важное значение в теории указанных задач. Например, в работе [10] исследованы уравнения с двумя параметрами, когда $\rho^{-1} A_{\tau}=\varepsilon$ кинематический коэффициент «кажущейся» вязкости турбулентного течения, соответствующий коэффициенту кинематической вязкости $\mu=\rho^{-1} \nu$ ламинарного течения ( $A_{\tau}$ - коэффициент турбулентного обмена). Поэтому, в данной работе изучается сингулярновозмущенная задача с двумя малыми параметрами в весовом пространстве $L_{h}^{2}(D)$, когда задается априорная информация о входных данных в $L^{2}\left(R^{2}\right)$.
\end{abstract}

Ключевые слова: сингулярно-возмущённая задача, интегрируемая функиия, вырожденная задача, малый параметр, единственное решение, интегральный оператор.

\section{THE CAUCHY PROBLEM FOR SINGULARLY PERTURBED INTEGRO- DIFFERENTIAL EQUATIONS WITH TWO SMALL PARAMETERS Omurov T.D. ${ }^{1}$, Alieva A.R. ${ }^{2}$}

\author{
${ }^{I}$ Omurov Taalaibek Dardaylovich - Doctor of Physical and Mathematical Sciences, Professor, \\ DEPARTMENT OF MATHEMATICAL ANALYSIS AND DIFFERENTIAL EQUATIONS, FACULTY OF \\ MATHEMATICS, INFORMATICS, \\ KYRGYZ NATIONAL UNIVERSITY NAMED AFTER J. BALASAGYN; \\ ${ }^{2}$ Alieva Ainur Rabatovna - Senior Researcher, \\ LABORATORY OF APPLIED MATHEMATICS AND INFORMATICS, \\ INSTITUTE OF THEORETICAL AND APPLIED MATHEMATICS OF THE KYRGYZ REPUBLIC NATIONAL \\ ACADEMY OF SCIENCES, \\ BISHKEK, REPUBLIC OF KYRGYZSTAN
}

\begin{abstract}
: in the singularly perturbed problems equations with two or more small parameters were studied in $[6,10]$ and the others, stability issues and conditional stability of solutions are important in theory of these problems.
\end{abstract}

For example, in [10] investigated the equation with two parameters when $\rho^{-1} A_{\tau}=\varepsilon$ - kinematicviscosity coefficient "apparent" of turbulent flow, corresponding to kinematic-viscosity coefficient of laminar flow ( $A_{\tau}$ - turbulent exchange coefficient).

Therefore, in this paper we study the singularly perturbed problem with two small parameters in the weighted space $L_{h}^{2}(D)$ when given prior information of the input data in $L^{2}\left(R^{2}\right)$.

Keywords: singularly perturbed problems, integrable function, degenerate problem, small parameter, a unique solution, an integral operator. 


\section{Введение}

Известно, что существенные трудности, связанные с вопросами разрешимостью, возникают при исследовании нелинейных сингулярно-возмущенных задач в неограниченных областях с одним малым параметром, когда в этих задачах малость погранслойной функции нарушается не в начальной точке, а на отрезке, где $x=t,((t, x) \in[0, T] \times R)$, а в случае $t \in R_{+}$, то малость нарушается в области $R_{+}$, где $x=t$. Тем более, в случае $(t, x, y) \in D=[0, T] \times R^{2}$, еще труднее, в чем и заключается актуальность исследований данной работы. Аналогичные трудности возникают и в сингулярно-возмущенных задачах с двумя малыми параметрами $[6,10]$ и более, когда независимые переменные допускают указанные условия, где доминируются интегро-дифференциальные уравнения в частных производных $[3,4,5]$ и др.

В связи с этим, в настоящей статье изучается нелинейное сингулярно-возмущенное интегро-дифференциальное уравнение четвертого порядка с двумя малыми параметрами с условием Коши на основе метода работы [8], дающий разложения асимптотического характера, где содержатся функции типа погранслоя и линейный интегральный оператор с остаточной функцией. При этом излагаемый метод модифицирует метод классической погранслойной функции $[1,2,4]$ с априорной информацией о входных данных в $L^{2}\left(R^{2}\right)$ [7].

Рассмотрим сингулярно-возмущенную задачу вида:

$$
\begin{aligned}
& \varepsilon_{1}^{2}\left[u_{t^{2} x^{2}}+u_{t x^{3}}\right]-\varepsilon_{2}\left[\varepsilon_{1}^{2}\left(u_{t y x^{2}}+u_{y x^{3}}\right)-u_{t y}-u_{y x}\right]=u_{t^{2}}+u_{t x}+f(t, x, y)+\lambda K u, \\
& \left\{\begin{array}{l}
u(0, x, y)=\vartheta(0, x, y)+b_{0}\left(x, y, \varepsilon_{1}, \varepsilon_{2}\right), \forall(x, y) \in R^{2} \\
u_{t}(0, x, y)=\vartheta_{t}(0, x, y)-b_{0 x}\left(x, y, \varepsilon_{1}, \varepsilon_{2}\right), \forall(x, y) \in R^{2} \\
K u \equiv \int_{R^{2}} K\left(t, x, y, \tau_{1}, \tau_{2}\right) u^{2}\left(t, \tau_{1}, \tau_{2}\right) d \tau_{1} d \tau_{2}, \forall\left(t, x, y, \tau_{1}, \tau_{2}\right) \in D_{1}, \\
D=[0, T] \times R^{2} ; \quad D_{1}=D \times R^{2}
\end{array}\right.
\end{aligned}
$$

где

$$
0<\lambda=\text { const }
$$$$
(0,1) \ni \varepsilon_{1}, \varepsilon_{2}-
$$

малые

параметры, $b_{0}\left(x, y, \varepsilon_{1}, \varepsilon_{2}\right) \in C^{3,1}\left(R^{2}\right), f(t, x, y), K\left(t, x, y, \tau_{1}, \tau_{2}\right)$ - заданные функции, при этом $C^{2,3,1}(D)$ э $f(t, x, y)$ - $\quad$ ограниченная функция $\quad$ в $0 \leq K\left(t, x, y, \tau_{1}, \tau_{2}\right) \in C^{2,3,1,0,0}\left(D_{1}\right)$ и интегрируемая функция по $\left(\tau_{1}, \tau_{2}\right)$ в $R^{2}$, причем

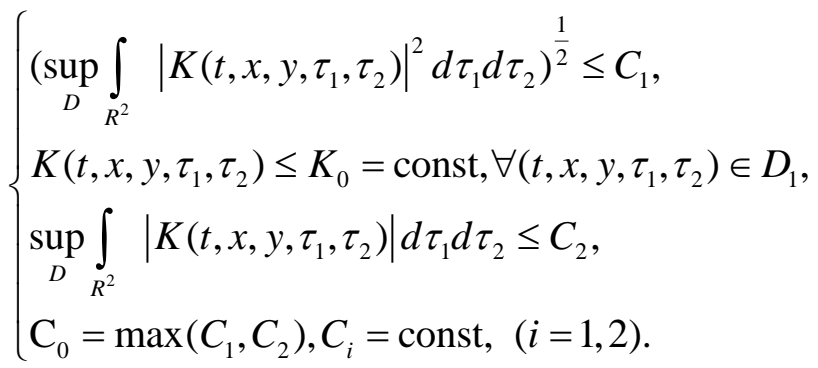

Для доказательства близости решений сингулярно-возмущенной и вырожденной задачи в пространстве $L_{h}^{2}(D)$, требуется априорная информация вида 


$$
\left\{\begin{array}{l}
b_{0}\left(x, y, \varepsilon_{1}, \varepsilon_{2}\right) \nrightarrow 0, \text { когда } \varepsilon_{1}, \varepsilon_{2} \rightarrow 0, \forall(x, y) \in R^{2}, \\
\left|b_{0}\left(x, y, \varepsilon_{1}, \varepsilon_{2}\right)\right| \leq m_{0}<\infty, \forall(x, y) \in R^{2}, \\
\left\|b_{0}\left(x, y, \varepsilon_{1}, \varepsilon_{2}\right)\right\|_{L^{2}\left(R^{2}\right)}=\left(\int_{R^{2}}\left|b_{0}\left(\tau_{1}, \tau_{2}, \varepsilon_{1}, \varepsilon_{2}\right)\right|^{2} d \tau_{1} d \tau_{2}\right)^{\frac{1}{2}} \leq m_{1} \varepsilon_{1}^{\gamma}, \\
0<\gamma<1 ; 0<m_{i}=\text { const, }(i=0,1) .
\end{array}\right.
$$

П. 1. Если $\varepsilon_{1}, \varepsilon_{2}=0$, то из (1) следует вырожденная задача:

$$
\begin{gathered}
\vartheta_{t^{2}}+\vartheta_{t x}=-[f(t, x, y)+\lambda K \vartheta], \\
\left.\vartheta(t, x, y)\right|_{t=0}=\vartheta(0, x, y) \equiv \varphi_{0}(x, y), \forall(x, y) \in R^{2}, \\
\left.\vartheta_{t}(t, x, y)\right|_{t=0}=\vartheta_{t}(0, x, y) \equiv \varphi_{1}(x, y), \forall(x, y) \in R^{2}, \\
C^{3,1}\left(R^{2}\right) \ni \varphi_{i}(x, y), \quad(i=0,1) .
\end{gathered}
$$

Задача Коши (4), (5) эквивалентно приводится к виду

$$
\left\{\begin{array}{l}
\vartheta(t, x)=\varphi_{0}(x-t, y)+\int_{0}^{t}\left\{\psi(x-(t-s), y)-\int_{0}^{s}[f(v, x-(t-s), y)+\right. \\
\left.\left.+\lambda \int_{R^{2}} K\left(v, x-(t-s), y, \tau_{1}, \tau_{2}\right) \vartheta^{2}\left(v, \tau_{1}, \tau_{2}\right) d \tau_{1} d \tau_{2}\right] d v\right\} d s \equiv(B \vartheta)(t, x, y), \\
\psi(x, y) \equiv \varphi_{1}(x, y)+\varphi_{0 x}(x, y)
\end{array}\right.
$$

при этом (6) удовлетворяет уравнение (4).

Действительно, дифференцируя (6) по совокупности аргументов и подставляя (4), получим

$$
\left\{\begin{array}{l}
\vartheta_{t}(t, x)=-\varphi_{0 h}(x-t, y)+\psi(x, y)-\int_{0}^{t}\left[f(s, x, y)+\lambda \int_{R^{2}} K\left(s, x, y, \tau_{1}, \tau_{2}\right) \times\right. \\
\left.\times \vartheta^{2}\left(s, \tau_{1}, \tau_{2}\right) d \tau_{1} d \tau_{2}\right] d s-\int_{0}^{t}\left\{\psi_{h_{1}}(x-(t-s), y)-\int_{0}^{s}\left[f_{h_{1}}(v, x-(t-s), y)+\right.\right. \\
\left.\left.+\lambda \int_{R^{2}} K_{h_{1}}\left(v, x-(t-s), y, \tau_{1}, \tau_{2}\right) \vartheta^{2}\left(v, \tau_{1}, \tau_{2}\right) d \tau_{1} d \tau_{2}\right] d v\right\} d s,\left(h=x-t, h_{1}=x-(t-s)\right), \\
\vartheta_{x}(t, x)=\varphi_{0 h}(x-t, y)+\int_{0}^{t}\left\{\psi_{h_{1}}(x-(t-s), y)-\int_{0}^{s}\left[f_{h_{1}}(v, x-(t-s), y)+\right.\right. \\
\left.\left.+\lambda \int_{R^{2}} K_{h_{1}}\left(v, x-(t-s), y, \tau_{1}, \tau_{2}\right) \vartheta^{2}\left(v, \tau_{1}, \tau_{2}\right) d \tau_{1} d \tau_{2}\right] d v\right\} d s, \\
\vartheta_{t}+\vartheta_{x}=\psi(x, y)-\int_{0}^{t}\left[f(s, x, y)+\lambda \int_{R^{2}} K\left(s, x, y, \tau_{1}, \tau_{2}\right) \vartheta^{2}\left(s, \tau_{1}, \tau_{2}\right) d \tau_{1} d \tau_{2}\right] d s, \\
-[f+\lambda K \vartheta]=\vartheta_{t^{2}}+\vartheta_{x t}=-\left[f(t, x, y)+\lambda \int_{R^{2}} K\left(t, x, y, \tau_{1}, \tau_{2}\right) \vartheta^{2}\left(t, \tau_{1}, \tau_{2}\right) d \tau_{1} d \tau_{2}\right]= \\
=-[f+\lambda K \vartheta], \quad \forall(t, x, y) \in D, \\
K \vartheta \equiv \int_{R^{2}} K\left(t, x, y, \tau_{1}, \tau_{2}\right) \vartheta^{2}\left(t, \tau_{1}, \tau_{2}\right) d \tau_{1} d \tau_{2}, \\
\psi(x, y) \equiv \varphi_{1}(x, y)+\varphi_{0 x}(x, y) .
\end{array}\right.
$$

Что и требовалось указать. 
С другой стороны, уравнение (6) является уравнением Вольтерра второго рода и она разрешима в классе функций $C^{2,3,1}(D)$, так как [9]:

$$
\left\{\begin{array}{l}
d=\lambda r_{0} C_{0} T^{2} \leq \frac{1}{2}, \\
B: S_{r}\left(\vartheta_{0}\right) \rightarrow S_{r}\left(\vartheta_{0}\right), \\
\left\|B \vartheta_{0}-\vartheta_{0}\right\|_{C} \leq(1-d) r ; \quad S_{r}\left(\vartheta_{0}\right)=\left\{\vartheta:\left|\vartheta-\vartheta_{0}\right| \leq r, \forall(t, x, y) \in D\right\},\left(\|\vartheta\|_{C} \leq r_{0}\right),
\end{array}\right.
$$

причем решение уравнение (6) находим методом Пикара

$\vartheta_{n+1}=B \vartheta_{n},(n=0,1, \ldots)$

с оценкой погрешности

$$
\left\|\vartheta_{n+1}-\vartheta_{n}\right\|_{C} \leq d\left\|\vartheta_{n}-\vartheta_{n-1}\right\|_{C} \leq \ldots \leq d^{n}\left\|\vartheta_{1}-\vartheta_{0}\right\|_{C} \leq d^{n}(1-d) r \underset{n \rightarrow \infty}{\stackrel{d<1}{\longrightarrow}} 0,
$$

где $\vartheta_{0}$ - начальное приближение. Кроме того, по условию задачи известные функции, входящие в уравнение непрерывно дифференцируемы до требуемого порядка по совокупности своих аргументов, то и решение уравнения (6) допускает аналогичное требование, т.е. имеет место: $C^{2,3,1}(D)$ э $\vartheta(t, x, y)$.

Лемма 1. В условиях (8), (9) задача (4), (5) разрешима в классе функций $C^{2,3,1}(D)$.

П.2. Чтобы найти решение задачи (1), (2), предположим

$$
\left\{\begin{array}{l}
u_{\varepsilon}=\vartheta(t, x, y)+\Pi\left(t, x, y, \varepsilon_{1}, \varepsilon_{2}\right)+(\mathfrak{I} \xi)(t, x, y), \\
\left.\vartheta(t, x, y)\right|_{t=0}=\vartheta(0, x, y), \quad \forall(x, y) \in R^{2}, \\
\left.\Pi\left(t, x, y, \varepsilon_{1}, \varepsilon_{2}\right)\right|_{t=0}=b_{0}\left(x, y, \varepsilon_{1}, \varepsilon_{2}\right), \quad \forall(x, y) \in R^{2}, \\
\mathfrak{I} \xi \equiv \frac{1}{\varepsilon_{1}^{2}} \int_{0}^{t} \int_{-\infty}^{x-t+v} e^{-\frac{1}{\varepsilon_{1}}(x-t+v-\tau)} \int_{\tau}^{\infty} e^{\frac{1}{\varepsilon_{1}}\left(\tau-\tau^{\prime}\right)} \xi\left(v, \tau^{\prime}, y\right) d \tau^{\prime} d \tau d v,
\end{array}\right.
$$

причем

$$
\left\{\begin{array}{l}
u_{t}=\vartheta_{t}+\Pi_{t}+(\mathfrak{I} \xi)_{t} \\
u_{x}=\vartheta_{x}+\Pi_{x}+(\mathfrak{I} \xi)_{x} \\
u_{t x}=\vartheta_{t x}+\Pi_{t x}+(\mathfrak{I} \xi)_{t x} \\
u_{t x^{2}}=\vartheta_{t x^{2}}+\Pi_{t x^{2}}+(\mathfrak{I} \xi)_{t x^{2}} \\
u_{x^{3}}=\vartheta_{x^{3}}+\Pi_{x^{3}}+(\mathfrak{I} \xi)_{x^{3}}
\end{array}\right.
$$

Следовательно, подставляя (10), (11) в (1) и при этом, учитывая (4) имеем 


$$
\begin{aligned}
& \vartheta_{t^{2}}+\vartheta_{t x}=-[f(t, x, y)+\lambda K \vartheta], \quad \forall(t, x, y) \in D, \\
& \left.\vartheta(t, x, y)\right|_{t=0}=\vartheta(0, x, y) \text {, } \\
& \left.\vartheta_{t}(t, x, y)\right|_{t=0}=\vartheta_{t}(0, x, y), \quad \forall(x, y) \in R^{2} \text {, } \\
& \Pi_{t}\left(t, x, y, \varepsilon_{1}, \varepsilon_{2}\right)+\Pi_{x}\left(t, x, y, \varepsilon_{1}, \varepsilon_{2}\right)=0 \text {, } \\
& \left.\Pi\left(t, x, y, \varepsilon_{1}, \varepsilon_{2}\right)\right|_{t=0}=b_{0}\left(x, y, \varepsilon_{1}, \varepsilon_{2}\right), \quad \forall(x, y) \in R^{2}, \\
& \varepsilon_{1}^{2} \frac{\partial}{\partial t}\left[(\mathfrak{I} \xi)_{t x^{2}}+(\mathfrak{I} \xi)_{x^{3}}\right]-\varepsilon_{2} \frac{\partial}{\partial y}\left[\varepsilon_{1}^{2}\left((\mathfrak{I} \xi)_{t x^{2}}+(\mathfrak{I} \xi)_{x^{3}}\right)-(\mathfrak{I} \xi)_{t}-(\mathfrak{I} \xi)_{x}\right]= \\
& \left\{=\frac{\partial}{\partial t}\left[(\Im \xi)_{t}+(\Im \xi)_{x}\right]+\lambda \int_{R^{2}} K\left(t, x, y, \tau_{1}, \tau_{2}\right)\left[2 \vartheta\left(t, \tau_{1}, \tau_{2}\right) \frac{1}{\varepsilon_{1}^{2}} \int_{0}^{t} \int_{-\infty}^{\tau_{1}-t+v} e^{-\frac{1}{\varepsilon_{1}}\left(\tau_{1}-t+v-\tau\right)} \times\right.\right. \\
& \times \int_{\tau}^{\infty} e^{\frac{1}{\varepsilon_{1}}\left(\tau-\tau^{\prime}\right)} \xi\left(v, \tau^{\prime}, \tau_{2}\right) d \tau^{\prime} d \tau d v+2 \Pi\left(t, \tau_{1}, \tau_{2}, \varepsilon_{1}, \varepsilon_{2}\right) \frac{1}{\varepsilon_{1}^{2}} \int_{0}^{t} \int_{-\infty}^{\tau_{1}-t+v} e^{-\frac{1}{\varepsilon_{1}}\left(\tau_{1}-t+v-\tau\right)} \times \\
& \left.\times \int_{\tau}^{\infty} e^{\frac{1}{\varepsilon_{1}}\left(\tau-\tau^{\prime}\right)} \xi\left(\nu, \tau^{\prime}, \tau_{2}\right) d \tau^{\prime} d \tau d \nu+\left(\frac{1}{\varepsilon_{1}^{2}} \int_{0}^{t} \int_{-\infty}^{\tau_{1}-t+v} e^{-\frac{1}{\varepsilon_{1}}\left(\tau_{1}-t+v-\tau\right)} \int_{\tau}^{\infty} e^{\frac{1}{\varepsilon_{1}}\left(\tau-\tau^{\prime}\right)} \xi\left(\nu, \tau^{\prime}, \tau_{2}\right) d \tau^{\prime} d \tau d v\right)^{2}\right] \times \\
& \times d \tau_{1} d \tau_{2}+\Upsilon\left(t, x, y, \varepsilon_{1}, \varepsilon_{2}\right), \\
& \Upsilon\left(t, x, y, \varepsilon_{1}, \varepsilon_{2}\right) \equiv-\varepsilon_{1}^{2}\left[\vartheta_{t^{2} x^{2}}+\vartheta_{t x^{3}}\right]+\varepsilon_{2}\left[\varepsilon_{1}^{2}\left(\vartheta_{t y x^{2}}+\vartheta_{y x^{3}}\right)-\vartheta_{t y}-\vartheta_{y x}\right]+\lambda \int_{R^{2}} K\left(t, x, y, \tau_{1}, \tau_{2}\right) \times \\
& \times\left[2 \vartheta\left(t, \tau_{1}, \tau_{2}\right) \Pi\left(t, \tau_{1}, \tau_{2}, \varepsilon_{1}, \varepsilon_{2}\right)+\Pi^{2}\left(t, \tau_{1}, \tau_{2}, \varepsilon_{1}, \varepsilon_{2}\right)\right] d \tau_{1} d \tau_{2}, \quad(t, x, y) \in D,
\end{aligned}
$$

где

$$
\begin{aligned}
& \left((\mathfrak{J} \xi)_{t}=\frac{1}{\varepsilon_{1}^{2}} \int_{-\infty}^{x} e^{-\frac{1}{\varepsilon_{1}}(x-\tau)} \int_{\tau}^{\infty} e^{\frac{1}{\varepsilon_{1}}\left(\tau-\tau^{\prime}\right)} \xi\left(t, \tau^{\prime}, y\right) d \tau^{\prime} d \tau-\frac{1}{\varepsilon_{1}^{2}} \int_{0}^{t} \int_{x-t+v}^{\infty} e^{\frac{1}{\varepsilon_{1}}\left(x-t+\nu-\tau^{\prime}\right)} \times\right. \\
& \times \xi\left(\nu, \tau^{\prime}, y\right) d \tau^{\prime} d \nu+\frac{1}{\varepsilon_{1}^{2}} \frac{1}{\varepsilon_{1}} \int_{0}^{t} \int_{-\infty}^{x-t+v} e^{-\frac{1}{\varepsilon_{1}}(x-t+v-\tau)} \int_{\tau}^{\infty} e^{\frac{1}{\varepsilon_{1}}\left(\tau-\tau^{\prime}\right)} \xi\left(\nu, \tau^{\prime}, y\right) d \tau^{\prime} d \tau d \nu, \\
& (\Im \xi)_{x}=\frac{1}{\varepsilon_{1}^{2}} \int_{0}^{t} \int_{x-t+v}^{\infty} e^{\frac{1}{\varepsilon_{1}}\left(x-t+v-\tau^{\prime}\right)} \xi\left(v, \tau^{\prime}, y\right) d \tau^{\prime} d \nu-\frac{1}{\varepsilon_{1}^{2}} \frac{1}{\varepsilon_{1}} \int_{0}^{t} \int_{-\infty}^{x-t+v} e^{-\frac{1}{\varepsilon_{1}}(x-t+v-\tau)} \times \\
& \times \int_{\tau}^{\infty} e^{\frac{1}{\varepsilon_{1}}\left(\tau-\tau^{\prime}\right)} \xi\left(\nu, \tau^{\prime}, y\right) d \tau^{\prime} d \tau d \nu \\
& \left\{(\mathfrak{J} \xi)_{t}+(\mathfrak{J} \xi)_{x}=\frac{1}{\varepsilon_{1}^{2}} \int_{-\infty}^{x} e^{-\frac{1}{\varepsilon_{1}}(x-\tau)} \int_{\tau}^{\infty} e^{\frac{1}{\varepsilon_{1}}\left(\tau-\tau^{\prime}\right)} \xi\left(t, \tau^{\prime}, y\right) d \tau^{\prime} d \tau,\right. \\
& (\mathfrak{I} \xi)_{t x}+(\mathfrak{I} \xi)_{x^{2}}=\frac{1}{\varepsilon_{1}^{2}} \int_{x}^{\infty} e^{\frac{1}{\varepsilon_{1}}\left(x-\tau^{\prime}\right)} \xi\left(t, \tau^{\prime}, y\right) d \tau^{\prime}-\frac{1}{\varepsilon_{1}^{2}} \frac{1}{\varepsilon_{1}} \int_{-\infty}^{x} e^{-\frac{1}{\varepsilon_{1}}(x-\tau)} \int_{\tau}^{\infty} e^{\frac{1}{\varepsilon_{1}}\left(\tau-\tau^{\prime}\right)} \times \\
& \times \xi\left(t, \tau^{\prime}, y\right) d \tau^{\prime} d \tau, \\
& (\mathfrak{J} \xi)_{t x^{2}}+(\mathfrak{I} \xi)_{x^{3}}=-\frac{1}{\varepsilon_{1}^{2}} \xi(t, x, y)+\frac{1}{\varepsilon_{1}^{2}} \frac{1}{\varepsilon_{1}} \int_{x}^{\infty} e^{\frac{1}{\varepsilon_{1}}\left(x-\tau^{\prime}\right)} \xi\left(t, \tau^{\prime}, y\right) d \tau^{\prime}- \\
& -\frac{1}{\varepsilon_{1}^{2}} \frac{1}{\varepsilon_{1}} \int_{x}^{\infty} e^{\frac{1}{\varepsilon_{1}}(x-\tau)} \xi\left(t, \tau^{\prime}, y\right) d \tau^{\prime}+\frac{1}{\varepsilon_{1}^{2}} \frac{1}{\varepsilon_{1}^{2}} \int_{-\infty}^{x} e^{-\frac{1}{\varepsilon_{1}}(x-\tau)} \int_{\tau}^{\infty} e^{\frac{1}{\varepsilon_{1}}\left(\tau-\tau^{\prime}\right)} \xi\left(t, \tau^{\prime}, y\right) d \tau^{\prime} d \tau= \\
& =-\frac{1}{\varepsilon_{1}^{2}} \xi(t, x, y)+\frac{1}{\varepsilon_{1}^{2}} \frac{1}{\varepsilon_{1}^{2}} \int_{-\infty}^{x} e^{-\frac{1}{\varepsilon_{1}}(x-\tau)} \int_{\tau}^{\infty} e^{\frac{1}{\varepsilon_{1}}\left(\tau-\tau^{\prime}\right)} \xi\left(t, \tau^{\prime}, y\right) d \tau^{\prime} d \tau .
\end{aligned}
$$




$$
\begin{gathered}
\Pi_{t}\left(t, x, y, \varepsilon_{1}, \varepsilon_{2}\right)+\Pi_{x}\left(t, x, y, \varepsilon_{1}, \varepsilon_{2}\right)=0, \\
\left.\Pi\left(t, x, y, \varepsilon_{1}, \varepsilon_{2}\right)\right|_{t=0}=b_{0}\left(x, y, \varepsilon_{1}, \varepsilon_{2}\right), \forall(x, y) \in R^{2}
\end{gathered}
$$

единственным точным образом определяется функция $\Pi\left(t, x, y, \varepsilon_{1}, \varepsilon_{2}\right)$, т.е.

$$
\Pi\left(t, x, y, \varepsilon_{1}, \varepsilon_{2}\right)=b_{0}\left(x-t, y, \varepsilon_{1}, \varepsilon_{2}\right), \forall(t, x, y) \in D,
$$

так как имеет место

$$
\left\{\begin{array}{l}
\Pi_{t}\left(t, x, y, \varepsilon_{1}, \varepsilon_{2}\right)=-b_{0 h}\left(x-t, y, \varepsilon_{1}, \varepsilon_{2}\right), \quad(h=x-t), \\
\Pi_{x}\left(t, x, y, \varepsilon_{1}, \varepsilon_{2}\right)=b_{0 h}\left(x-t, y, \varepsilon_{1}, \varepsilon_{2}\right), \quad \forall(t, x, y) \in D, \\
\Pi_{t}+\Pi_{x}=0 .
\end{array}\right.
$$

При этом, учитывая заданную информацию (3) относительно функции $\Pi\left(t, x, y, \varepsilon_{1}, \varepsilon_{2}\right)$ получим оценку в $L_{h}^{2}(D)$ в виде

$$
\left\{\begin{array}{l}
\|\Pi\|_{L_{h}^{2}(D)}=\left(\sup _{[0, T]} \int_{0}^{t} \int_{R^{2}} h\left(\tau_{1}, \tau_{2}\right)\left|\Pi\left(s, \tau_{1}, \tau_{2}, \varepsilon_{1}, \varepsilon_{2}\right)\right|^{2} d \tau_{1} d \tau_{2} d s\right)^{\frac{1}{2}} \leq \sqrt{\tilde{h_{0}} T} m_{1} \varepsilon_{1}^{\gamma} \underset{\varepsilon_{1} \rightarrow 0}{\longrightarrow} 0, \\
\left\|b_{0}\right\|_{L_{h}^{2}(D)}=\left(\int_{R^{2}}\left|b_{0}\left(\tau_{1}, \tau_{2}, \varepsilon_{1}, \varepsilon_{2}\right)\right|^{2} d \tau_{1} d \tau_{2}\right)^{\frac{1}{2}} \leq m_{1} \varepsilon_{1}^{\gamma}, \\
0<\gamma<1 ; 0<m_{1}=\text { const, } \\
0 \leq h(x, y) \leq \tilde{h}_{0}=\text { const }<\infty, \forall(x, y) \in R^{2}: \int_{R^{2}} h\left(\tau_{1}, \tau_{2}\right) d \tau_{1} d \tau_{2} \leq h_{0}=\text { const. }
\end{array}\right.
$$

Далее, учитывая (13), (16) из (12) получим

$$
\left\{\begin{array}{l}
\xi_{t}(t, x, y)-\varepsilon_{2} \xi_{y}(t, x, y)=-\left\{\lambda \int _ { R ^ { 2 } } K ( t , x , y , \tau _ { 1 } , \tau _ { 2 } ) \left[2 \vartheta\left(t, \tau_{1}, \tau_{2}\right) \frac{1}{\varepsilon_{1}^{2}} \int_{0}^{t} \int_{-\infty}^{\tau_{1}-t+v} e^{-\frac{1}{\varepsilon_{1}\left(\tau_{1}-t+v-\tau\right)} \times} \times\right.\right. \\
\times \int_{\tau}^{\infty} e^{\frac{1}{\varepsilon_{1}}\left(\tau-\tau^{\prime}\right)} \xi\left(v, \tau^{\prime}, \tau_{2}\right) d \tau^{\prime} d \tau d v+2 b_{0}\left(\tau_{1}-t, \tau_{1}, \tau_{2}, \varepsilon_{1}, \varepsilon_{2}\right) \frac{1}{\varepsilon_{1}^{2}} \int_{0}^{t} \int_{-\infty}^{\tau_{1}-t+v} e^{-\frac{1}{\varepsilon_{1}}\left(\tau_{1}-t+v-\tau\right)} \times \\
\left.\times \int_{\tau}^{\infty} e^{\frac{1}{\varepsilon_{1}}\left(\tau-\tau^{\prime}\right)} \xi\left(v, \tau^{\prime}, \tau_{2}\right) d \tau^{\prime} d \tau d v+\left(\frac{1}{\varepsilon_{1}^{2}} \int_{0}^{t} \int_{-\infty}^{\tau_{1}-t+v} e^{-\frac{1}{\varepsilon_{1}}\left(\tau_{1}-t+v-\tau\right)^{\infty}} \int_{\tau}^{\infty} e^{\frac{1}{\varepsilon_{1}}\left(\tau-\tau^{\prime}\right)} \xi\left(v, \tau^{\prime}, \tau_{2}\right) d \tau^{\prime} d \tau d v\right)^{2}\right] \times \\
\left.\times d \tau_{1} d \tau_{2}+\Upsilon\left(t, x, y, \varepsilon_{1}, \varepsilon_{2}\right)\right\} \equiv(H \xi)(t, x, y), \\
\Upsilon\left(t, x, y, \varepsilon_{1}, \varepsilon_{2}\right) \equiv-\varepsilon_{1}^{2}\left[\vartheta_{t^{2} x^{2}}+\vartheta_{t x^{3}}\right]+\varepsilon_{2}\left[\varepsilon_{1}^{2}\left(\vartheta_{t y x^{2}}+\vartheta_{y x^{3}}\right)-\vartheta_{t y}-\vartheta_{y x}\right]+\lambda \int_{R^{2}} K\left(t, x, y, \tau_{1}, \tau_{2}\right) \times \\
\times\left[2 \vartheta\left(t, \tau_{1}, \tau_{2}\right) b_{0}\left(\tau_{1}-t, \tau_{1}, \tau_{2}, \varepsilon_{1}, \varepsilon_{2}\right)+b_{0}^{2}\left(\tau_{1}-t, \tau_{1}, \tau_{2}, \varepsilon_{1}, \varepsilon_{2}\right)\right] d \tau_{1} d \tau_{2}, \quad(t, x, y) \in D, \\
\left|\Upsilon\left(t, x, y, \varepsilon_{1}, \varepsilon_{2}\right)\right| \leq 2 \tilde{r}_{0}\left(\varepsilon_{1}^{2}+\varepsilon_{2} \varepsilon_{1}^{2}+\varepsilon_{2}\right)+\lambda\left(2 r_{0}\left(\int_{R^{2}}\left|K\left(t, x, y, \tau_{1}, \tau_{2}\right)\right|^{2} d \tau_{1} d \tau_{2}\right)^{\frac{1}{2}} \times\right. \\
\times\left(\int_{R^{2}}\left|b_{0}\left(\tau_{1}, \tau_{2}, \varepsilon_{1}, \varepsilon_{2}\right)\right|^{2} d \tau_{1} d \tau_{2}\right)^{\frac{1}{2}}+K_{0}\left(\int_{R^{2}}\left|b_{0}\left(\tau_{1}, \tau_{2}, \varepsilon_{1}, \varepsilon_{2}\right)\right|^{2} d \tau_{1} d \tau_{2}\right)^{\frac{1}{2}} \times \\
\left.\times\left(\int_{R^{2}}\left|b_{0}\left(\tau_{1}, \tau_{2}, \varepsilon_{1}, \varepsilon_{2}\right)\right|^{2} d \tau_{1} d \tau_{2}\right)^{\frac{1}{2}}\right) \leq 2 \tilde{r}_{0}\left(\varepsilon_{1}^{2}+\varepsilon_{2} \varepsilon_{1}^{2}+\varepsilon_{2}\right)+\lambda\left(2 r_{0} C_{1} m_{1} \varepsilon_{1}^{\gamma}+K_{0}\left(m_{1} \varepsilon_{1}^{\gamma}\right)^{2}\right)= \\
=\Delta_{1}\left(\varepsilon_{1}, \varepsilon_{2}\right), \forall(t, x, y) \in D, \\
\Upsilon\left(t, x, y, \varepsilon_{1}, \varepsilon_{2}\right) \underset{\varepsilon_{1}, \varepsilon_{2} \rightarrow 0}{\longrightarrow} 0, \forall(t, x, y) \in D, \\
\left|\vartheta_{t^{2} x^{2}}\right|,\left|\vartheta \vartheta_{t x^{3}}\right|,\left|\vartheta \vartheta_{t y x^{2}}\right|,\left|\vartheta \vartheta_{y x^{3}}\right|,\left|\vartheta_{t y}\right|,\left|\vartheta \vartheta_{y x}\right| \leq \tilde{r}_{0}, \forall(t, x, y) \in D,\left(\|\vartheta\|_{C} \leq r_{0}\right) .
\end{array}\right.
$$


По условию задачи начальные условия относительно функция $u$ определяется в виде (2), поэтому, на основе (10), (16) имеем

$$
\begin{aligned}
& \left\{\begin{array}{l}
u_{\varepsilon}=\vartheta(t, x, y)+\Pi\left(t, x, y, \varepsilon_{1}, \varepsilon_{2}\right)+(\Im \xi)(t, x, y), \\
u_{t}=\vartheta_{t}+\Pi+(\Im \xi)
\end{array}\right. \\
& u_{t}=\vartheta_{t}+\Pi_{t}+(\mathfrak{I} \xi)_{t}, \\
& \Pi\left(t, x, y, \varepsilon_{1}, \varepsilon_{2}\right)=b_{0}\left(x-t, y, \varepsilon_{1}, \varepsilon_{2}\right), \forall(t, x, y) \in D, \\
& \left.u\right|_{t=0}=\left.\left(\vartheta(t, x, y)+b_{0}\left(x-t, y, \varepsilon_{1}, \varepsilon_{2}\right)+(\Im \xi)\right)\right|_{t=0}=\vartheta(0, x, y)+b_{0}\left(x, y, \varepsilon_{1}, \varepsilon_{2}\right) \text {, } \\
& \left\{\begin{array}{l}
\left.u_{t}\right|_{t=0}=\left.\left(\vartheta_{t}(t, x, y)-b_{0 h}\left(x-t, y, \varepsilon_{1}, \varepsilon_{2}\right)+(\Im \xi)_{t}\right)\right|_{t=0}=\vartheta_{t}(0, x, y)-b_{0 x}\left(x, y, \varepsilon_{1}, \varepsilon_{2}\right), \\
\left.(\Im \xi \xi)_{t}\right|_{t=0}=\left[\frac{1}{\varepsilon_{1}^{2}} \int_{-\infty}^{x} e^{-\frac{1}{\varepsilon_{1}}(x-\tau)} \int_{\tau}^{\infty} e^{\frac{1}{\varepsilon_{1}}\left(\tau-\tau^{\prime}\right)} \xi\left(t, \tau^{\prime}, y\right) d \tau^{\prime} d \tau-\frac{1}{\varepsilon_{1}^{2}} \int_{0}^{t} \int_{x-t+v}^{\infty} e^{\frac{1}{\varepsilon_{1}}\left(x-t+v-\tau^{\prime}\right)} \times\right. \\
\left.\times \xi\left(v, \tau^{\prime}, y\right) d \tau^{\prime} d v+\frac{1}{\varepsilon_{1}^{2}} \frac{1}{\varepsilon_{1}} \int_{0}^{t} \int_{-\infty}^{x-t+v} e^{-\frac{1}{\varepsilon_{1}}(x-t+v-\tau)} \int_{\tau}^{\infty} e^{\frac{1}{\varepsilon_{1}}\left(\tau-\tau^{\prime}\right)} \xi\left(v, \tau^{\prime}, y\right) d \tau^{\prime} d \tau d v\right]\left.\right|_{t=0}=0, \\
\xi(0, x, y)=0, \quad \forall(x, y) \in R^{2} .
\end{array}\right.
\end{aligned}
$$

При условии (19) из (18) следует уравнение вида

$$
\begin{aligned}
& \xi(t, x, y)=-\int_{0}^{t}\left\{\lambda \int _ { R ^ { 2 } } K ( s , x , y + \varepsilon _ { 2 } ( t - s ) , \tau _ { 1 } , \tau _ { 2 } ) \left[2 \vartheta\left(s, \tau_{1}, \tau_{2}\right) \frac{1}{\varepsilon_{1}^{2}} \int_{0}^{s} \int_{-\infty}^{\tau_{1}-s+v} e^{-\frac{1}{\varepsilon_{1}}\left(\tau_{1}-s+v-\tau\right)} \times\right.\right. \\
& \times \int_{\tau}^{\infty} e^{\frac{1}{\varepsilon_{1}\left(\tau-\tau^{\prime}\right)}} \xi\left(v, \tau^{\prime}, \tau_{2}\right) d \tau^{\prime} d \tau d v+2 b_{0}\left(\tau_{1}-s, \tau_{1}, \tau_{2}, \varepsilon_{1}, \varepsilon_{2}\right) \frac{1}{\varepsilon_{1}^{2}} \int_{0}^{s} \int_{-\infty}^{\tau_{1}-s+v} e^{-\frac{1}{\varepsilon_{1}}\left(\tau_{1}-s+v-\tau\right)} \times \\
& \left.\times \int_{\tau}^{\infty} e^{\frac{1}{\varepsilon_{1}}\left(\tau-\tau^{\prime}\right)} \xi\left(v, \tau^{\prime}, \tau_{2}\right) d \tau^{\prime} d \tau d v+\left(\frac{1}{\varepsilon_{1}^{2}} \int_{0}^{s} \int_{-\infty}^{\tau_{1}-s+v} e^{-\frac{1}{\varepsilon_{1}}\left(\tau_{1}-s+v-\tau\right)} \int_{\tau}^{\infty} e^{\frac{1}{\varepsilon_{1}}\left(\tau-\tau^{\prime}\right)} \xi\left(v, \tau^{\prime}, \tau_{2}\right) d \tau^{\prime} d \tau d v\right)^{2}\right] \times
\end{aligned}
$$

$\left.\times d \tau_{1} d \tau_{2}+\Upsilon\left(s, x, y+\varepsilon_{2}(t-s), \varepsilon_{1}, \varepsilon_{2}\right)\right\} d s \equiv(P \xi)(t, x, y)$.

Действительно, дифференцируя (20) по $t, y$ и полученные выражения, подставляя в (18) имеем

$$
\left\{\begin{array}{l}
\xi_{t}=H \xi-\int_{0}^{t}\left\{\lambda \int _ { R ^ { 2 } } \varepsilon _ { 2 } K _ { h _ { 1 } } ( s , x , y + \varepsilon _ { 2 } ( t - s ) , \tau _ { 1 } , \tau _ { 2 } ) \left[2 \vartheta\left(s, \tau_{1}, \tau_{2}\right) \frac{1}{\varepsilon_{1}^{2}} \int_{0}^{s} \int_{-\infty}^{\tau_{1}-s+v} e^{-\frac{1}{\varepsilon_{1}}\left(\tau_{1}-s+v-\tau\right)} \int_{\tau}^{\infty} e^{\frac{1}{\varepsilon_{1}}\left(\tau-\tau^{\prime}\right)} \times\right.\right. \\
\times \xi\left(v, \tau^{\prime}, \tau_{2}\right) d \tau^{\prime} d \tau d v+2 b_{0}\left(\tau_{1}-s, \tau_{1}, \tau_{2}, \varepsilon_{1}, \varepsilon_{2}\right) \frac{1}{\varepsilon_{1}^{2}} \int_{0}^{s} \int_{-\infty}^{s \tau_{1}-s+v} e^{-\frac{1}{\varepsilon_{1}}\left(\tau_{1}-s+v-\tau\right)} \int_{\tau}^{\infty} e^{\frac{1}{\varepsilon_{1}}\left(\tau-\tau^{\prime}\right)} \xi\left(v, \tau^{\prime}, \tau_{2}\right) d \tau^{\prime} d \tau d v+ \\
\left.+\left(\frac{1}{\varepsilon_{1}^{2}} \int_{0}^{s} \int_{-\infty}^{\tau_{1}-s+v} e^{-\frac{1}{\varepsilon_{1}}\left(\tau_{1}-s+v-\tau\right)} \int_{\tau}^{\infty} e^{\frac{1}{\varepsilon_{1}}\left(\tau-\tau^{\prime}\right)} \xi\left(v, \tau^{\prime}, \tau_{2}\right) d \tau^{\prime} d \tau d v\right)^{2}\right] d \tau_{1} d \tau_{2}+\varepsilon_{2} \Upsilon_{h_{1}}(s, x, y+ \\
\left.\left.+\varepsilon_{2}(t-s), \varepsilon_{1}, \varepsilon_{2}\right)\right\} d s \equiv H \xi+\varepsilon_{2} H_{1} \xi, \\
\xi_{y}=-\int_{0}^{t}\left\{\lambda \int _ { R ^ { 2 } } K _ { h _ { 1 } } ( s , x , y + \varepsilon _ { 2 } ( t - s ) , \tau _ { 1 } , \tau _ { 2 } ) \left[2 \vartheta\left(s, \tau_{1}, \tau_{2}\right) \frac{1}{\varepsilon_{1}^{2}} \int_{0}^{s} \int_{-\infty}^{\tau_{1}-s+v} e^{-\frac{1}{\varepsilon_{1}}\left(\tau_{1}-s+v-\tau\right)} \int_{\tau}^{\infty} e^{\frac{1}{\varepsilon_{1}}\left(\tau-\tau^{\prime}\right)} \xi\left(v, \tau^{\prime}, \tau_{2}\right) \times\right.\right. \\
\times d \tau^{\prime} d \tau d v+2 b_{0}\left(\tau_{1}-s, \tau_{1}, \tau_{2}, \varepsilon_{1}, \varepsilon_{2}\right) \frac{1}{\varepsilon_{1}^{2}} \int_{0}^{s} \int_{-\infty}^{\tau_{1}-s+v} e^{-\frac{1}{\varepsilon_{1}}\left(\tau_{1}-s+v-\tau\right)} \int_{\tau}^{\frac{1}{\varepsilon_{1}}\left(\tau-\tau^{\prime}\right)} \xi\left(v, \tau^{\prime}, \tau_{2}\right) d \tau^{\prime} d \tau d v+ \\
\left.+\left(\frac{1}{\varepsilon_{1}^{2}} \int_{0}^{s} \int_{-\infty}^{\tau_{1}-s+v} e^{-\frac{1}{\varepsilon_{1}}\left(\tau_{1}-s+v-\tau\right)} \int_{\tau}^{\infty} e^{\frac{1}{\varepsilon_{1}}\left(\tau-\tau^{\prime}\right)} \xi\left(v, \tau^{\prime}, \tau_{2}\right) d \tau^{\prime} d \tau d v\right)^{2}\right] d \tau_{1} d \tau_{2}+\Upsilon_{h_{1}}(s, x, y+ \\
\left.\left.+\varepsilon_{2}(t-s), \varepsilon_{1}, \varepsilon_{2}\right)\right\} d s \equiv H_{1} \xi, \\
h_{1}=y+\varepsilon_{2}(t-s), \quad \\
H_{1} \xi \equiv-\int_{0}^{t}\left\{\lambda \int _ { R ^ { 2 } } K _ { h _ { 1 } } ( s , x , y + \varepsilon _ { 2 } ( t - s ) , \tau _ { 1 } , \tau _ { 2 } ) \left[2 \vartheta\left(s, \tau_{1}, \tau_{2}\right) \frac{1}{\varepsilon_{1}^{2}} \int_{0}^{s} \int_{-\infty}^{\tau_{1}-s+v} e^{-\frac{1}{\varepsilon_{1}}\left(\tau_{1}-s+v-\tau\right)} \int_{\tau}^{\infty} e^{\frac{1}{\varepsilon_{1}}\left(\tau-\tau^{\prime}\right)} \xi\left(v, \tau^{\prime}, \tau_{2}\right) \times\right.\right.
\end{array}\right.
$$




$$
\left\{\begin{array}{l}
\times d \tau^{\prime} d \tau d v+2 b_{0}\left(\tau_{1}-s, \tau_{1}, \tau_{2}, \varepsilon_{1}, \varepsilon_{2}\right) \frac{1}{\varepsilon_{1}^{2}} \int_{0}^{s} \int_{-\infty}^{\tau_{1}-s+v} e^{-\frac{1}{\varepsilon_{1}}\left(\tau_{1}-s+v-\tau\right)} \int_{\tau}^{\infty} e^{\frac{1}{\varepsilon_{1}}\left(\tau-\tau^{\prime}\right)} \xi\left(v, \tau^{\prime}, \tau_{2}\right) d \tau^{\prime} d \tau d v+ \\
\left.\left.+\left(\frac{1}{\varepsilon_{1}^{2}} \int_{0}^{s} \int_{-\infty}^{\tau_{1}-s+v} e^{-\frac{1}{\varepsilon_{1}\left(\tau_{1}-s+v-\tau\right)}} \int_{\tau}^{\infty} e^{\frac{1}{\varepsilon_{1}}\left(\tau-\tau^{\prime}\right)} \xi\left(v, \tau^{\prime}, \tau_{2}\right) d \tau^{\prime} d \tau d v\right)^{2}\right] d \tau_{1} d \tau_{2}+\Upsilon_{h_{1}}\left(s, x, y+\varepsilon_{2}(t-s), \varepsilon_{1}, \varepsilon_{2}\right)\right\} d s, \\
H \xi=\xi_{t}-\varepsilon_{2} \xi_{y}=H \xi+\varepsilon_{2} H_{1} \xi-\varepsilon_{2} H_{1} \xi=H \xi .
\end{array}\right.
$$

Что требовалось показать.

С другой стороны, уравнение (20) является интегральным уравнением Вольтерра второго рода. Поэтому, не нарушая общности, допускаем, что если относительно оператора $P$ выполняются условия Банаха, т.е.

$$
\left\{\begin{array}{l}
d_{P}=\lambda T^{2} C_{0}\left(m_{1}+\frac{2}{3} T r_{1}\right)+\lambda r_{0} C_{0} T^{2}<1, \\
P: S_{r_{1}} \rightarrow S_{r_{1}}, \\
S_{r_{1}}(0)=\left\{\xi:|\xi(t, x, y)| \leq r_{1}, \forall(t, x, y) \in D\right\} ; \quad\|(P 0)(t, x, y)\|_{C} \leq\left(1-d_{P}\right) r_{1}: \\
\|(P \xi)(t, x, y)\|_{C} \leq\|(P \xi)(t, x, y)-(P 0)(t, x, y)\|_{C}+\|(P 0)(t, x, y)\|_{C} \leq d_{P} r_{1}+\left(1-d_{P}\right) r_{1}=r_{1},
\end{array}\right.
$$

здесь

$$
\begin{aligned}
& \varepsilon \in(0,1) ; C_{0}=\max \left(C_{1}, C_{2}\right) ; \quad \text { см. }(8), d=\lambda r_{0} C_{0} T^{2} \leq \frac{1}{2}, \\
& \left|\xi_{2}-\xi_{1}\right|=\mid-\int_{0}^{t}\left\{\lambda \int _ { R ^ { 2 } } K ( s , x , y + \varepsilon _ { 2 } ( t - s ) , \tau _ { 1 } , \tau _ { 2 } ) \left[2 \vartheta\left(s, \tau_{1}, \tau_{2}\right) \frac{1}{\varepsilon_{1}^{2}} \int_{0}^{s} \int_{-\infty}^{\tau_{1}-s+v} e^{-\frac{1}{\varepsilon_{1}}\left(\tau_{1}-s+\nu-\tau\right)} \times\right.\right. \\
& \times \int_{\tau}^{\infty} e^{\frac{1}{\varepsilon_{1}}\left(\tau-\tau^{\prime}\right)} \xi_{2}\left(v, \tau^{\prime}, \tau_{2}\right) d \tau^{\prime} d \tau d v+2 b_{0}\left(\tau_{1}-s, \tau_{1}, \tau_{2}, \varepsilon_{1}, \varepsilon_{2}\right) \frac{1}{\varepsilon_{1}^{2}} \int_{0}^{s} \int_{-\infty}^{\tau_{1}-s+v} e^{-\frac{1}{\varepsilon_{1}}\left(\tau_{1}-s+v-\tau\right)} \times \\
& \left.\times \int_{\tau}^{\infty} e^{\frac{1}{\varepsilon_{1}}\left(\tau-\tau^{\prime}\right)} \xi_{2}\left(v, \tau^{\prime}, \tau_{2}\right) d \tau^{\prime} d \tau d v+\left(\frac{1}{\varepsilon_{1}^{2}} \int_{0}^{s} \int_{-\infty}^{\tau_{1}-s+v} e^{-\frac{1}{\varepsilon_{1}}\left(\tau_{1}-s+v-\tau\right)} \int_{\tau}^{\infty} e^{\frac{1}{\varepsilon_{1}}\left(\tau-\tau^{\prime}\right)} \xi_{2}\left(v, \tau^{\prime}, \tau_{2}\right) d \tau^{\prime} d \tau d v\right)^{2}\right] \times \\
& \left.\times d \tau_{1} d \tau_{2}+\Upsilon\left(s, x, y+\varepsilon_{2}(t-s), \varepsilon_{1}, \varepsilon_{2}\right)\right\} d s+ \\
& -\int_{0}^{t}\left\{\lambda \int _ { R ^ { 2 } } K ( s , x , y + \varepsilon _ { 2 } ( t - s ) , \tau _ { 1 } , \tau _ { 2 } ) \left[2 \vartheta\left(s, \tau_{1}, \tau_{2}\right) \frac{1}{\varepsilon_{1}^{2}} \int_{0}^{s} \int_{-\infty}^{\tau_{1}-s+v} e^{-\frac{1}{\varepsilon_{1}}\left(\tau_{1}-s+v-\tau\right)} \times\right.\right. \\
& \times \int_{\tau}^{\infty} e^{\frac{1}{\varepsilon_{1}}\left(\tau-\tau^{\prime}\right)} \xi_{1}\left(\nu, \tau^{\prime}, \tau_{2}\right) d \tau^{\prime} d \tau d \nu+2 b_{0}\left(\tau_{1}-s, \tau_{1}, \tau_{2}, \varepsilon_{1}, \varepsilon_{2}\right) \frac{1}{\varepsilon_{1}^{2}} \int_{0}^{s} \int_{-\infty}^{\tau_{1}-s+v} e^{-\frac{1}{\varepsilon_{1}}\left(\tau_{1}-s+v-\tau\right)} \times \\
& \left.\times \int_{\tau}^{\infty} e^{\frac{1}{\varepsilon_{1}}\left(\tau-\tau^{\prime}\right)} \xi_{1}\left(\nu, \tau^{\prime}, \tau_{2}\right) d \tau^{\prime} d \tau d \nu+\left(\frac{1}{\varepsilon_{1}^{2}} \int_{0}^{s} \int_{-\infty}^{\tau_{1}-s+\nu} e^{-\frac{1}{\varepsilon_{1}}\left(\tau_{1}-s+\nu-\tau\right)} \int_{\tau}^{\infty} e^{\frac{1}{\varepsilon_{1}}\left(\tau-\tau^{\prime}\right)} \xi_{1}\left(\nu, \tau^{\prime}, \tau_{2}\right) d \tau^{\prime} d \tau d \nu\right)^{2}\right] \times \\
& \left.\times d \tau_{1} d \tau_{2}+\Upsilon\left(s, x, y+\varepsilon_{2}(t-s), \varepsilon_{1}, \varepsilon_{2}\right)\right\} d s \mid \leq\left(\lambda T^{2}\left(C_{1} m_{1} \varepsilon_{1}^{\gamma}+\frac{2}{3} C_{2} \operatorname{Tr}_{1}\right)+\lambda r_{0} C_{2} T^{2}\right) \times \\
& \times\left\|\xi_{2}-\xi_{1}\right\|_{C} \leq\left(\lambda T^{2} C_{0}\left(m_{1}+\frac{2}{3} T r_{1}\right)+\lambda r_{0} C_{0} T^{2}\right) \times\left\|\xi_{2}-\xi_{1}\right\|_{C}=d_{P} \times\left\|\xi_{2}-\xi_{1}\right\|_{C},
\end{aligned}
$$

то уравнение (20) имеет единственное решение в $C(D)$, причем

$$
\|\xi\|_{C} \leq\left(1-d_{P}\right)^{-1} T\left\|\Upsilon\left(t, x, y, \varepsilon_{1}, \varepsilon_{2}\right)\right\|_{C} \leq\left(1-d_{P}\right)^{-1} T \Delta_{1}\left(\varepsilon_{1}, \varepsilon_{2}\right)=\Delta_{2}\left(\varepsilon_{1}, \varepsilon_{2}\right) \underset{\varepsilon_{1}, \varepsilon_{2} \rightarrow 0}{\longrightarrow} 0 \text {. }
$$

Поэтому решение (20) находим методом Пикара и при этом имеем

$$
\left\{\begin{array}{l}
\xi_{n+1}=P \xi_{n},(n=0,1, \ldots), \\
\left\|\xi_{n+1}-\xi\right\|_{C} \leq d_{P}^{n+1} r_{1} \underset{n \rightarrow \infty}{\longrightarrow} 0 .
\end{array}\right.
$$


Лемма 2. Если имеют место условия (21), (22), то уравнение (20) разрешимо в $C(D)$.

Таким образом, мы показали, что непрерывно-ограниченное решение интегрального уравнения (20) есть решение сингулярно-возмущенного интегро-дифференциального уравнения (18). Следовательно, учитывая (10), (17) и (22) получим

$$
\left\{\begin{array}{l}
\left\|u_{\varepsilon}(t, x, y)-\vartheta(t, x, y)\right\|_{L_{h}^{2}(D)} \leq \sqrt{2}\left[\sup _{[0, T]} \int_{0}^{t} \int_{R^{2}} h\left(\tau_{1}, \tau_{2}\right)\left|\Pi\left(s, \tau_{1}, \tau_{2}, \varepsilon_{1}, \varepsilon_{2}\right)\right|^{2} d \tau_{1} d \tau_{2} d s+\right. \\
\left.+\left(T \Delta_{2}\left(\varepsilon_{1}, \varepsilon_{2}\right)\right)^{2} T h_{0}\right]^{\frac{1}{2}} \leq \sqrt{2}\left[\tilde{h}_{0} T\left(m_{1} \varepsilon_{1}^{\gamma}\right)^{2}+\left(T \Delta_{2}\left(\varepsilon_{1}, \varepsilon_{2}\right)\right)^{2} T h_{0}\right]^{\frac{1}{2}}=N_{0}\left(\varepsilon_{1}, \varepsilon_{2}\right) \underset{\varepsilon_{1} \rightarrow 0}{\longrightarrow} 0 \\
0<\gamma<1 ; 0<m_{1}=\text { const, } \\
0 \leq h(x, y) \leq \tilde{h}_{0}=\text { const }<\infty, \forall(x, y) \in R^{2}: \int_{R^{2}} h\left(\tau_{1}, \tau_{2}\right) d \tau_{1} d \tau_{2} \leq h_{0}=\text { const. }
\end{array}\right.
$$

Теорема 1. В условиях лемм 1, 2 и (24) близость решение сингулярно-возмущенной и вырожденной задачи оценима в смысле $L_{h}^{2}(D)$ по правилу (24), когда $\varepsilon_{1}, \varepsilon_{2} \rightarrow 0$.

\section{Сиисок литературы / References}

1. Бутузов В.Ф. Угловой погранслой в сингулярно-возмущенных задачах с частными производными // Дифференц. уравнения, 1979. Т. 15. Вып. 10. С. 1848-1862.

2. Васильева А.Б., Бутузов В.Ф. Асимптотические разложения решений сингулярновозмущенных уравнений. Москва: Наука, 1973. С. 272.

3. Винокуров В.П. Асимптотические поведение решений одного класса интегродифференциальных уравнений Вольтерра // Дифференц. уравнения. Т. 3. № 10. С. 17321744.

4. Иманалиев М.И. Методы решения нелинейных обратных задач и их приложение. Фрунзе: Илим, 1977. С. 348.

5. Касымов К.А., Дауылбаев М.К. Об оценке решений задачи Коши с начальным скачком любого порядка для линейных сингулярно-возмущенных интегро-дифференциальных уравнений // ДУ, 1999. Т. 35. Вып. 6. С. 822-830.

6. Ландау Л.Д., Лифщиц Е.М. Теоретическая физика: Т. 6. Гидродинамика. Москва: Наука, 1988. C. 736.

7. Омуров Т.Д., Туганбаев М.М. Прямые и обратные задачи односкоростной теории переноса // ИТ и ПМ НАН КР. Бишкек: Илим, 2010. С. 116.

8. Омуров Т.Д., Алиева А. Задача коши для нелинейного сингулярно-возмущенного интегродифференциального уравнения третьего порядка в неограниченной области // Приволжский научный вестник, 2016. № 12-1 (64). С. 36-43.

9. Треногин В.А. Функциональный анализ. Москва: Наука, 1980. С. 496.

10. Шлихтинг Г. Теория пограничного слоя. Москва: Наука, 1974. С. 712. 


\title{
ПОЛНЫЕ СЕМЕЙСТВА U-НЕПРЕРЫВНЫХ ФУНКЦИЙ Чекеев А.А. ${ }^{1}$, Абдраимова М.А. ${ }^{2}$, Чанбаева А.И. ${ }^{3}$ Email: Chekeev1791@scientifictext.ru
}

\footnotetext{
${ }^{1}$ Чекеев Асылбек Асакеевич - хабилитированный доктор математики, доктор физико-математических наук, профессор;

${ }^{2}$ Абдраимова Махабат Асанбековна - кандидат физико-математических наук, дочент;

${ }^{3}$ Чанбаева Айгуль Издибаевна - соискатель,

кафедра алгебры, геометрии, топологии и преподавания высшей математики, факультет математики и информатики,

Кыргызский национальнылй университет, г. Бишкек, Кыргызская Республика
}

\begin{abstract}
Аннотация: в статье, по аналогии с работой 3. Фролика [4], введено понятие полного семейства $u$-непрерывных функций, являющихся частью алгебры $C_{u}(X)$ [2]. Установлена характеристика $U$-полных семейств через вложения в некоторую степень числовой прямой. Доказано, что полные семейства и-непрерывных функций можно охарактеризовать посредством вложения данного пространства в свою $\beta$-подобную компактификацию [1]. Доказано, что равномерное пространство является реалкомпактным в категории ZUnif [3], если и только если, на нем сущеествует полное семейство и-непрерывных функиий некоторой мощности.
\end{abstract}

Ключевые слова: $u$-открытые, $u$-замкнутые множества, $и$-непрерывная функиия, полнота, соZ-отображение, компактификачия.

\section{A COMPLETE FAMILIES OF U- CONTINUOUS FUNCTIONS Chekeev A.A. ${ }^{1}$, Abdraimova M.A. ${ }^{2}$, Chanbaeva A.I. ${ }^{3}$}

\author{
${ }^{\text {I}}$ Chekeev Asylbek Asakeevich - Habilitated Doctor of Mathematics, Full Doctor of Mathematics, Doctor of \\ Physical and Mathematical Sciences, Professor; \\ ${ }^{2}$ Abdraimova Mahabat Asanbekovna - PhD Mathematics, Candidate of Physical and Mathematical Sciences, \\ Associate Professor; \\ ${ }^{3}$ Chanbaeva Aigul Izdibaevna - competitor, \\ DEPARTMENT OF ALGEBRA, GEOMETRY, TOPOLOGY AND TEACHING OF MATHEMATICS, \\ FACULTY OF MATHEMATICS AND INFORMATICS, \\ KYRGYZ NATIONAL UNIVERSITY, BISHKEK, REPUBLIC OF KYRGYZSTAN
}

Abstract: in this paper, by analogy with Z. Frolik's work [4], the concept of complete family of $\boldsymbol{U}$ continuous functions is introduced, which are the part of algebra $C_{u}(X)$ [2]. The characterization of $\boldsymbol{U}$-complete families by means of embeddings into some power of real line is established. It has been proved, that the complete families of $\boldsymbol{U}$ - continuous functions can be characterized by means of embeddings given space into its $\beta$-like compactification [1]. It has been proved, that uniform space is a realcompact in the category ZUnif [3], if and only if, there exists a complete family of $u-$ continuous functions of some cardinality on it.

Keywords: $u-$ open, $u-$ closed sets, $u-$ continuous function, completeness, $C O Z-$ mapping, compactification.

УДК 515.12

Вся необходимая информация и обозначения взяты из статей [1], [2], [4] и доклада [3]. Знак 口 - завершение доказательства.

ОПРЕДЕЛЕНИЕ 1. Семейство $F \subset C_{u}(X) u$ - непрерывных функций на равномерном пространстве $u X$ называется полным, если выполнено условие: Если $\xi$ - центрированная 
система $U$-замкнутых множеств в $U X$ и у каждой функиии $f \in \mathcal{F}$ существует $Z_{f} \in \xi$ такое, что $f$ ограничено на $Z_{f}$, что $\cap \xi \neq \varnothing$.

ТЕОРЕМА 2 Пусть $F \subset C_{u}(X)$ - семейство $U$ - непрерывных функций на равномерном пространстве $U X$. Тогда $\mathcal{F}$ полно если и только, если выполнены следующчие условия:

(I) Если $F$ - пересечение $U$-замкнутых множеств в $и X$ и если каждая функция $f \in \mathcal{F}$ ограничена на $F$, то $F$ - компакт.

(II) Если $\left\{Z_{f}: f \in F\right\}$ - центрированное семейство $u$-замкнутьх множеств в $u X$ и $f$ ограничено на $Z_{f}$, то $\bigcap\left\{Z_{f}: f \in F\right\} \neq \varnothing$.

ДОКАЗАТЕЛЬСТВО. Если $\mathcal{F}$ - полное семейство $\boldsymbol{u}$ - непрерывных функций, то выполнение пунктов (I) и (II) очевидно.

Докажем обратное. Пусть $\xi$ - центрированное семейсто $u$ - замкнутых множеств в $u X$ и для каждой $f \in F$ существует $Z_{f} \in \xi$, на котором $f$ ограничено. По (II) множество $\bigcap\left\{Z_{f}: f \in \mathcal{F}\right\}=F$ непусто, т.е. $F \neq \varnothing$. По (I) $F$ компактно. Для доказательства того, что $\cap \xi \neq \varnothing$ необходимо показать, что $\xi \wedge F=\{Z \cap F: Z \in \xi\}$ является центрированным семейством. Пусть $Z_{1}$ и $Z_{2}$ из $\xi$. Тогда

$$
\begin{gathered}
\bigcap\left\{Z_{1} \cap Z_{2} \cap Z_{f}: f \in F\right\}=F \cap Z_{1} \cap Z_{2} \neq \varnothing, \\
\bigcap(\xi \wedge F)=\cap \xi \cap F \neq \varnothing \text {, т.е. } \cap \xi \neq \varnothing .
\end{gathered}
$$

TЕОРЕМА 3. Пусть $F \subset C_{u}(X)$ - семейство $u$-непрерывных функиий $и$ $g=\triangle_{f \in F} f: u X \rightarrow \prod_{f \in \mathcal{F}} \mathbb{R}_{f}$, где $\mathbb{R}_{f}=\mathbb{R}, f \in \mathcal{F}$, - диагональ семейства $\mathcal{F}$. Тогда семейство $F$ полно если и только, если $g$ COZ - совершенно.

ДОКАЗАТЕЛЬСТВО. Пусть $K$ компактно в $\mathbb{R}^{F}=\prod_{f \in \mathcal{F}} \mathbb{R}_{f}$. Так как $f=\pi_{f} \circ g$ для любой функции $f: u X \rightarrow \mathbb{R}_{f}$, где $\pi_{f}: \mathbb{R}^{F} \rightarrow \mathbb{R}_{f}$ - естественная проекция, то каждая функция $f$ из $F$ ограничена на $g^{-1}(K)$. Имеем, $f(x)=\pi_{f}(g(x))$ для любой точки $x \in X$ и $f\left(g^{-1}(K)\right)=\pi_{f}(K)$. Ясно, что $\pi_{f}(K)$ компактно в $\mathbb{R}_{f}$ и является ограниченым в $\mathbb{R}_{f}$ относительно Евклидовой метрики на $\mathbb{R}_{f}$. Так как функционально замкнутые множества есть база топологии замкнутых множеств, то компакт $K$ является пересечением некоторого семейства функционально замкнутых множеств в $\mathbb{R}_{f}$. Так как $g-C O Z-$ морфизм, то $g^{-1}(K)$ является пересечением некоторого семейства $u$ - замкнутых множеств. Следовательно, по теореме $2, g^{-1}(K)$ - компакт в $X$ и $g: u X \rightarrow \mathbb{R}^{F}$ - компактное отображение. 
Для доказательства замкнутости отображения $g$ достаточно показать, что $g$ $\operatorname{coz}-z_{u}$ - замкнуто. Пусть $Z_{0} u$-замкнуто в $u X$. Предположим противное, т.е. $g\left(Z_{0}\right)=F$ не замкнуто в $\mathbb{R}^{F}$. Пусть $y \in[F] \backslash F$, где $[F]$ - замыкание в $\mathbb{R}^{F}$ и $y=\left(y_{f}: f \in F\right) \in \mathbb{R}^{F}$. Рассмотрим следующее семейство $\xi=\left\{Z_{n, f}: f \in F, n \in \mathbb{N}\right\} \cup\left\{Z_{0}\right\} \subset \mathcal{Z}_{u} u$ - замкнутых множеств в $u X$, где $Z_{n, f}=\left\{x \in X:\left|f(x)-y_{f}\right| \leq 1 / n\right\} . \quad$ Тогда $\quad$ точка $\quad y \quad$ является $\quad$ точкой прикосновения для множества $F$ и семейство $\xi$ центрировано. Каждое $f$ из $F$ ограничено на $Z_{n, f}$, следовательно в силу полноты $F, \cap \xi \neq \varnothing$. Но $\cap \xi=g^{-1}(y) \cap Z_{0}$ и $y \notin g\left(Z_{0}\right)=F$, т.е. $\cap \xi=\varnothing$. Противоречие. Итак, $g: u X \rightarrow \mathbb{R}^{F}$ cOZ - совершенно.

Обратно, пусть $g: u X \rightarrow \mathbb{R}^{F} \quad C O Z-$ совершенно или, что равносильно $c O Z-z_{u}-$ замкнуто и компактно. Пусть $\xi-z_{u}$ - ультрафильтр в $u X$ и предположим, что для любого $f \in F$ найдется $Z_{f} \in \xi$, на котором $f$ ограничено. В силу компактности $g$ достаточно доказать, что существует точка $y=\left(y_{f}: f \in \mathcal{F}\right) \in \mathbb{R}^{\mathcal{F}}$ такая, что $\xi \wedge g^{-1}(y)$ центрировано. Тогда из компактности прообраза $g^{-1}(y)$ следует, что $\cap\left(\xi \wedge g^{-1}(y)\right) \neq \varnothing$, т.е. $\cap \xi \neq \varnothing$. Пусть $f \in F$, то $f$ ограничено на $Z_{f} \in \xi$. Тогда найдется ограниченный интервал $I_{f} \subset \mathbb{R}_{f}$ такой, что $f\left(Z_{f}\right) \subset I_{f}$. Пусть $K_{1}, \ldots, K_{n}$ - конечное покрытие $I_{f}$ замкнутыми интервалами $\operatorname{diam} \leq 1 / n$. Каждое $f^{-1}\left(K_{i}\right), i=1, \ldots, n, u$ - замкнуто в $u X$ и $\bigcup_{i=1}^{n} f^{-1}\left(K_{i}\right) \supset Z_{f} \in \xi$. Так как $\xi-z_{u}$ - ультрафильтр в $u X$ для некоторого $i=1, \ldots, n, f^{-1}\left(K_{i}\right) \in \xi$. Таким образом, для любого $n \in \mathbb{N}$ и любой функции $f \in \mathcal{F}$ существует замкнутый интервал $\operatorname{diam} \leq 1 / n$ такой, что $Z_{n, f}=f^{-1}\left(K_{n, f}\right) \in \xi$. Очевидно, что для каждой функции $f \in \mathcal{F}$ семейство $\left\{K_{n, f}\right\}_{n \in \mathbb{N}}$ - центрированное семейство компактных множеств. Следовательно, $\bigcap_{n=1}^{\infty} K_{n, f} \neq \varnothing$ и это пересечение содержит только одну точку, так как $\operatorname{diam}_{n, f} \rightarrow 0 \quad$ при $\quad n \rightarrow \infty$. Положим $\left\{y_{f}\right\}=\bigcap_{n=1}^{\infty} K_{n, f} . \quad$ Тогда $\quad$ точка $y=\left(y_{f}: f \in F\right)$ искомая. Действительно, $g(X)$ компактно в $\mathbb{R}^{F}$ и $y \in g(X)$. Покажем, что $\xi \wedge g^{-1}(y)$ центрировано, т.е. если $Z \in \xi$, то $Z \cap g^{-1}(y) \neq \varnothing$. 
Предположим противное. Пусть $Z \in \xi$ такое, что $Z \cap g^{-1}(y)=\varnothing$. По условию $g(Z)$ замкнуто в $\mathbb{R}^{F}$. По предположению $y \notin F$. Тогда существует окрестность $V$ точки $y$ такая, что $V \cap F=\varnothing$. Поскольку $\operatorname{diam}_{n, f} \rightarrow 0$ при $n \rightarrow \infty$ существют $K_{i}=K_{n, f} \quad(i=1,2, \ldots, k)$ такие, что $\bigcap_{i=1}^{k} f_{i}^{-1}\left(K_{i}\right) \bigcap Z=\varnothing$, т.е. $\bigcap_{i=1}^{k} f_{i}^{-1}\left(K_{i}\right) \notin \xi . \quad$ Противоречие, $\quad$ так $\quad$ как $\quad f_{i}^{-1}\left(K_{i}\right) \in \xi, \quad i=1,2, \ldots, k$, $\bigcap_{i=1}^{k} f_{i}^{-1}\left(K_{i}\right) \in \xi$. Итак, $\xi \wedge g^{-1}(y)$ центрировано.

СЛЕДСТВИЕ 4. Если равномерное пространство $u X \mathbb{R}-z_{u}-$ полно, то алгебра $C_{u}(X)$ всех $u-$ непрерывных функиий является полной.

ДОКАЗАТЕЛЬСТВО вытекает из того факта, что если $u X \mathbb{R}-z_{u}$-полно, то $u X$ $\operatorname{coz}$ - гомеоморфно вкладывается в $\mathbb{R}^{C_{u}(X)}$ [2].

Естественно, что для характеризации $\mathbb{R}-z_{u}$ - полных равномерных пространств возникает вопрос об использовании части алгебры $C_{u}(X)$.

TЕОРЕМА 5. Пусть $F \subset C_{u}(X)$ - такое семейство $u-$ непрерывных функций, что $f \geq 1$ для каждой функиии $f \in \mathcal{F}$. Для каждой функииии $f \in \mathcal{F}$ обозначим $g_{f}=1 / f \in C_{u}^{*}(X), \quad \beta_{u} g_{f} \quad$ - продолжение $g_{f}$ на $\beta_{u} X \quad$ u $\operatorname{coz}\left(\beta_{u} g\right)=\left\{x \in \beta_{u} X: \beta_{u} g_{f}(x) \neq 0\right\}$. Тогда $F$ полно если и только, если $X=\bigcap_{f \in \mathcal{F}} \operatorname{coz}\left(\beta_{u} g_{f}\right)$.

ДОКАЗАТЕЛЬСТВО. Предположим, что существует такая точка $x \in \beta_{u} X$, что $x \in \bigcap_{f \in F} \operatorname{coz}\left(\beta_{u} g_{f}\right) \backslash X$. Пусть $\xi$ - семейство функционально замкнутых множеств в $\beta_{u} X$, являющихся окрестностями точки $x$. Ясно, что $\{x\}=\cap \xi \subset \beta_{u} X \backslash X$. Тогда $\xi \wedge X=\{Z \cap X: Z \in \xi\}$ - центрированное семейство $u$ - замкнутых множеств в $u X$ с пустым пересечением. Зафиксируем $f_{0} \in F$. Тогда $\beta_{u} g_{f_{0}}(x) \neq 0$. Пусть $Z_{f}=\left\{y \in \beta_{u} X:\left|\beta_{u} g_{f_{0}}(y)\right| \geq \varepsilon\right\}$. Тогда $x \in Z_{f}$ и $y \in Z_{f} \cap X \quad$ влечет $|f(x)| \leq 1 / \varepsilon$, т.е. $f$ ограничено на $Z_{f} \cap X$. Противоречие.

Обратно, пусть $\xi$ - центрированная система $u$-замкнутых множеств в $u X$ такая, что для каждой функции $f \in \mathcal{F}$ существует $Z_{f} \in \xi$, на котором $f$ ограничено. Так как 
$\beta_{u} X \quad$ компактно, то $F_{0}=\bigcap\left\{[Z]_{\beta_{u} X}: Z \in \xi\right\} \neq \varnothing$. Достаточно показать, что $F_{0} \subset X$. Покажем, что $\left[Z_{f}\right]_{\beta_{u} X} \subset \operatorname{coz}\left(\beta_{u} g_{f}\right)$ каждой функции $f \in \mathcal{F}$. Каждая $f$ ограничена на $Z_{f}$, т.е. $|f(x)| \leq M=$ const $\neq 0$ для любой точки $x \in Z_{f}$. Тогда, естественно, имеем $\left|\beta_{u} g_{f}(x)\right| \geq M^{-1}$ для всех $x \in\left[Z_{f}\right]_{\beta_{u} X}$. Для любой точки $x \in\left[Z_{f}\right]_{\beta_{u} X} \quad$ имеем $\quad \beta_{u} g_{f}(x) \neq 0, \quad$ т.е. $\quad x \in \operatorname{coz}\left(\beta_{u} g_{f}\right) \quad$ Итак, $F_{0}=\bigcap\left\{[Z]_{\beta_{u} X}: Z \in \xi\right\} \subset \bigcap\left\{\left[Z_{f}\right]_{\beta_{u} X}: f \in F\right\} \subset X$

СЛЕДСТВИЕ 6. Пусть $F \subset C_{u}(X)$ - полное семейство $u-$ непрерывных функций и $|F| \leq \mathfrak{m}$. Тогда равномерное пространство $u X$ есть пересечение семейства функиионально открытых множеств в компакте $\beta_{u} X$ мощности $\leq \mathfrak{m}$.

ДОКАЗАТЕЛЬСТВО следует непосредственно из теоремы 5.

На основе вышеизложенных результатов определим аналоги $\mathfrak{N}(\mathfrak{m})$ - пространств, введенных 3. Фроликом [4], в категории ZUnif .

ОПРЕДЕЛЕНИЕ 7. Пусть $\mathfrak{m}$ - некоторый кардинал. Равномерное пространство $u X$ называется $\mathrm{COZ}-\mathfrak{N}(\mathfrak{m})-$ пространством, если существует семейство $\mathcal{F} u-$ непрерывных функций мощности $\leq \mathfrak{m}$.

TЕОРЕМА 8. Равномерное пространство $u X$ является $\operatorname{coz}-\mathfrak{N}(\mathfrak{m})-$ пространством, если и только, если существует $\mathrm{COZ}-$ совершенное отображение $g$ из $u X_{\text {в }} \mathbb{R}^{\mathfrak{m}}$.

ДОКАЗАТЕЛЬСТВО. Пусть $u X$ является $c o z-\mathfrak{N}(\mathfrak{m})-$ пространством. Тогда существует полное семейство $\mathcal{F} \quad u$ - непрерывных функций мощности $\leq \mathfrak{m}$. Пусть $g=\triangle_{f \in F} f: u X \rightarrow \mathbb{R}^{\mathfrak{m}}$. Тогда, по теореме $3, g$ COZ - совершенно.

Обратно, пусть $g \operatorname{coz}$ - совершенно отображает $u X$ в $\mathbb{R}^{\mathfrak{m}}=\prod_{s \in S} \mathbb{R}_{s}$, где $\mathbb{R}=\mathbb{R}_{s}$ для всех $s \in S$ и $|S|=\mathfrak{m}$. Пусть $f_{s}=\pi_{s} \circ g$, где $\pi_{s}: \mathbb{R}^{\mathfrak{m}} \rightarrow \mathbb{R}_{s}$ - естественная проекция. Каждая $f_{s}: u X \rightarrow \mathbb{R}_{s}$ является $\operatorname{coz}$ - морфизмом как композиция $\mathrm{COZ}-$ морфизма $g$ и проекции $\pi_{s}$ (которая, естественно, является $C O Z-$ морфизмом). Ясно, что $g(x)=\left\{f_{s}(x): s \in S\right\}$. Тогда из теоремы 3 следует, что семейство $\left\{f_{s}\right\}_{s \in S} u-$ непрерывных функций является полным.

ПРЕДЛОЖЕНИЕ 9. Пусть $\mathcal{F}$ - полное семейство $\boldsymbol{U}$-непрерывных функций на равномерном пространстве $u X$ и $F$-замкнутое подпространство $X$. Тогда семейство $\left.F\right|_{F}=\left\{\left.f\right|_{F}: f \in F\right\}-u^{\prime}-$ непрерывных функичй на $u^{\prime} F$, где $u^{\prime}=\left.u\right|_{F}$, является полным. Замкнутое подпространство $\mathrm{COZ}-\mathfrak{N}(\mathfrak{m})-$ пространства является соZ $-\mathfrak{N}(\mathfrak{m})-$ пространством. 
ДОКАЗАТЕЛЬСТВО следует непосредственно из теоремs 2.

Следующее утверждение - частный случай теоремы 2.10 [4].

TЕОРЕМА 10. Равномерное пространство $u X$ является $\mathbb{R}-z_{u}-$ полно, если и только, если оно $\mathrm{COZ}$ - гомеоморфно некоторому замкнутому подпространству $\mathbb{R}^{\mathfrak{m}}$ для некоторого $\mathfrak{m}$.

ДОКАЗАТЕЛЬСТВО следует непосредственно из теоремы 2.

ТЕОРЕМА 11. Для равномерного пространства $U X$ следующие условия равносильны:

(1) Существует $\mathcal{F}$ - полное семейство $U$-непрерывных функций мошности $\leq \mathfrak{m}$.

(2) Существует $\mathrm{COz}$ - совершенное отображение из $u X$ в $\mathbb{R}^{\mathfrak{m}}$.

(3) Существует $\mathrm{COZ}$-совершенное отображение из $u X$ в $\operatorname{coz}-\mathfrak{N}(\mathfrak{m})-$ пространство.

(4) $и X$ есть пересечение $\mathfrak{m}$ функционально открытых множеств в Самюэлевской компактификаичи $s_{u} X$.

(5) $u X$ есть пересечение $\mathfrak{m}$ функционально открытых множеств в $\beta$ - подобной компактификачии $\beta_{u} X$.

ДОКАЗАТЕЛЬСТВО следует непосредственно из всех определений $c o z-\mathfrak{N}(\mathfrak{m})-$ пространств.

TЕОРЕМА 12. Пусть $f: u X \rightarrow v Y$ - $\mathrm{COZ}-$ совершенное сюръективное отображение и $v Y \quad \mathrm{Oz}-\mathfrak{Y}(\mathfrak{m})$ - пространство. Тогда равномерное пространство $u X$ также является $\mathrm{COZ}-\mathfrak{N}(\mathfrak{m})-$ пространством.

ДОКАЗАТЕЛЬСТВО. Пусть $\beta_{u} f: \beta_{u} X \rightarrow \beta_{v} Y$ - непрерывное продолжение на $\beta-$ подобные компактификации $\beta_{u} X$ и $\beta_{v} Y \operatorname{coz}$ - совершенного отображения $f$. Так как $v Y-\operatorname{COZ}-\mathfrak{N}(\mathfrak{m})$ - пространство, то по теореме $10, v Y$ есть пересечение $\mathfrak{m}$ функционально открытых в $\beta \gamma$ множеств, т.е. $Y=\bigcap_{s \in \mathfrak{m}} U_{s}$, где $U_{s}$ функционально открыто в $\beta_{v} Y$ для любого $S<\mathfrak{m}$. Так как $X \subset \beta_{u} f^{-1}(Y)$, то $X=\bigcap_{s \in \mathfrak{m}} \beta_{u} f^{-1}\left(U_{s}\right)$, где каждое $\beta_{u} f^{-1}\left(U_{s}\right)$ функционально открыто в $\beta_{u} X$ для каждого $s<\mathfrak{m}$. Следовательно, $u X$ является $c o z-\mathfrak{N}(\mathfrak{m})-$ пространством. $\square$

\section{Список литературы / References}

1. Чекеев А.А., Рахманкулов Б.З. О $\beta$-подобной компактификации и инверсно-замкнутых кольцах равномерных пространств // Вестник науки и образования, 2016. № 6 (18). С. 6-14.

2. Chekeev A.A. Uniformities for Wallman compactifications and realcompactifications // Topol. Appl., 2016. V. 201. P. 145-156.

3. Chekeev A.A., Kasymova T.J. Ultrafilter-completeness on zero-sets of uniformly continuous functions // TOPOSYM, 2016. 25-29 July (Prague, Czech Republic), Topology Atlas, 2016. P. 76 (to appear).

4. Frolik Z. Applications of complete families of continuous functions to the theory of Q-spaces // Czech. Math. J. 11, 1961. P. 115-133. 


\title{
INVERSION-CLOSED ALGEBRAS OF FUNCTIONS ON A UNIFORM SPACE \\ Chekeev A.A. ${ }^{1}$, Kasymova T.D ${ }^{2}$, Rakhmankulov B.Z. ${ }^{3}$ \\ Email: Chekeev1791@scientifictext.ru
}

\author{
${ }^{1}$ Chekeev Asylbek Asakeevich - Habilitated Doctor of Mathematics, Full Doctor of Mathematics, Doctor of \\ Physical and Mathematical Sciences, Professor; \\ ${ }^{2}$ Kasymova Tumar Dzhapashevna - PhD Mathematics, Candidate of Physical and Mathematical Sciences, \\ Associate Professor; \\ ${ }^{3}$ Rakhmankulov Bakhtiar Zulpukarovich - senior lecturer, \\ DEPARTMENT OF ALGEBRA, GEOMETRY, TOPOLOGY AND TEACHING OF MATHEMATICS, \\ FACULTY OF MATHEMATICS AND INFORMATICS, \\ KYRGYZ NATIONAL UNIVERSITY, BISHKEK, REPUBLIC OF KYRGYZSTAN
}

Abstract: for any inversion-closed algebra $\mathcal{A}$ in sense $[22,18,19]$ on Tychonoff space $X$ there is a uniformity $u$ such, that $\mathcal{A}$ coincides with an algebra $C_{u}(X)$ [7] of all $u$-continuous functions on some uniform space $u X$. For a ring structure of algebra $C_{u}(X)$ and subring $C_{u}^{*}(X)$ the uniform analogues of the Stone Theorem [26] and Gelfand-Kolmogoroff Theorem [15] have been proved. For a uniform space $u X$ the concept of $Z_{u}-$ completeness is considered, which is equivalent to the realcompactness in the category ZUnif [8], determined by means of realcompactification $v_{u} X[7]$, various characterizations of $z_{u}$ - complete uniform spaces are established.

Keywords: algebra, uniformity, $u$-open, $u$-closed sets, normal base, coz-mapping, COZ - fine space, ring, ideal, maximal ideal, compactification.

\section{ИНВЕРСНО-ЗАМКНУТЫЕ АЛГЕБРЫ ФУНКЦИЙ НА РАВНОМЕРНОМ ПРОСТРАНСТВЕ Чекеев А.А. ${ }^{1}$, Касымова Т.Д. ${ }^{2}$, Рахманкулов Б.3. ${ }^{3}$}

\footnotetext{
${ }^{l}$ Чекеев Асылбек Асакеевич - хабилитированный доктор математики, доктор физико-математических наук, профессор;

${ }^{2}$ Касымова Тумар Джапашевна - кандидат физико-математических наук, дочент;

${ }^{3}$ Рахманкулов Бахтияр Зулпукарович - старший преподаватель, кафедра алгебры, геометрии, топологии и преподавания высшей математики, факультет математики и информатики,

Кыргызский национальный университет, г. Бишкек, Кыргызская Республика
}

Аннотация: для любой инверсно-замкнутой алгебры $\mathcal{A}$ в смысле работ $[22,18,19]$ на тихоновском пространстве $X$ существует равномерность $U$ такая, что $\mathcal{A}$ совпадает с алгеброй $C_{u}(X)$ [7] всех $U$-непрерывных функций на некотором равномерном пространстве $u X$. Для кольцевой структуры алгебры $C_{u}(X)$ и подкольца $C_{u}^{*}(X)$ доказаны равномерные аналоги теорем Стоуна [26] и Гельфанда-Колмогорова [15]. Для равномерного пространства $u X$ рассмотрено понятие $z_{u}$-полноты, которое эквивалентно реалкомпактности в категории ZUnif [8], определенное посредством реалкомпактификации $\bigcup_{u} X$ [7], установлены различные характеристики $Z_{u}$ - полных равномерных пространств. 
Ключевые слова: алгебра, равномерность, $\boldsymbol{U}$-открытые, $\boldsymbol{U}$-замкнутые множества, нормальная база, СOZ-отображение, $\mathrm{COZ}$ - тонкое пространство, кольцо, идеал, максимальный идеал, компактификация.

УДК 515.12

\section{Introduction and preliminaries}

In [7] by zero-sets a normal base $Z_{u}$ of all uniformly continuous functions of the uniform space $u X$ Wallman compactification $\beta_{u} X=\omega\left(X, Z_{u}\right)[1,12,16,18,19,21,22,24,25]$ and Wallman realcompactification $v_{u} X=v\left(X, Z_{u}\right)[18,19,22,24,25]$ had been constructed. A normal base $Z_{u}$ is a separating, nest-generated intersection ring (s.n.-g.i.r.) on $X \quad$ [25] and the compactification $\beta_{u} X$ is a $\beta$ - like compactification [24]. The uniformities on $X$, by which $\beta_{u} X$ and $v_{u} X$ are completions, had been described. The properties of $\beta$-like compactification are similar in many respects with Stone-Čech compactification [7, Th.2.6, Cor. 2.7, Th. 2.8] and it is closely linked with the ring of all $u$ continuous functions and the ring of all bounded $u$ continuous functions [7, Th. 2.6 (3)]. The compactification $\beta_{u} X$ and realcompactification $v_{u} X$ yielded a number of results on the partial order and relations of dimensions in the lattice of all compactifications [7, Part 3].

Under an algebra $\mathcal{A}$ on $X[22,18,19]$ is meant a subalgebra of $C(X)$, containing all constants, separating points and closed sets, and it is closed in $C(X)$ with respect to uniform convergence (i.e. if sequence of functions $\left\{f_{n}\right\}_{n \in \mathbb{N}}$ of $\mathcal{A}$ is uniformly converging to function $f$, then $f \in \mathcal{A}$ ) and inversion (i.e. $f \in \mathcal{A}$ and $Z(f)=\varnothing$, then $1 / f \in \mathcal{A}$ ). If $\mathcal{A}$ is an algebra on $X$, then $\mathcal{A}^{*}$ is a set of all bounded functions of $\mathcal{A}$, it is a ring and $H\left(\mathcal{A}^{*}\right)$ is a structure space of algebra $\mathcal{A}$, i.e. it is a space of maximal ideals of the algebra $\mathcal{A}$ with the Stone topology [26] and $H(\mathcal{A})$ is the intersection of all cozero-sets in $H\left(\mathcal{A}^{*}\right)$, containing $X$. $H\left(\mathcal{A}^{*}\right)$ is a compactification of $X$ and a ring $\mathcal{A}^{*}$ is isomorphic to the ring $C\left(H\left(\mathcal{A}^{*}\right)\right)$ $\left(\mathcal{A}^{*}=C\left(H\left(\mathcal{A}^{*}\right)\right)\right)$ in terms $\left.[19,22]\right)$. By Lemma $1.4[25]$, traces on $X$ of zero-sets of $H\left(\mathcal{A}^{*}\right)$, which are zero-sets of functions from $\mathcal{A}^{*}$, form s.,n.-g.i.r. $Z\left(\mathcal{A}^{*}\right)=\left\{Z(f): f \in \mathcal{A}^{*}\right\}$. From [22] it follows, that $\mathcal{A}$ precisely is a family of all continuous functions of $H\left(\mathcal{A}^{*}\right)$ into two-point compactification $[-\infty ;+\infty]$ of a real line $\mathbb{R}$, which are real-valued on $X$. Then $Z(\mathcal{A})=Z\left(\mathcal{A}^{*}\right)=\left\{Z \cap X: Z \in Z\left(H\left(\mathcal{A}^{*}\right)\right)\right\}$, where $Z\left(H\left(\mathcal{A}^{*}\right)\right)=\left\{Z(f): f \in C\left(H\left(\mathcal{A}^{*}\right)\right)\right\}$ and $Z(\mathcal{A})$ is s.n.-g.i.r..

Thus, if $\mathcal{A}$ is an algebra on $X$, then Wallman compactification $\omega\left(X, Z_{u}\right)$ is $H\left(\mathcal{A}^{*}\right)$ and Wallman realcompactification $U\left(X, Z_{u}\right)$ is $H(\mathcal{A})$, but an algebra $\mathcal{A}$ cannot be isomorphic to some algebra $C(Y)$ [25, Ex. 3.13], [22, Ex.1.22], [19, Ex. 9.7]. 
In [7] it had been proved, that for uniform space $u X$ a set $C_{u}(X)$ of all $u-$ continuous functions on $u X$ forms an algebra [7, Prop. 2.2] and $Z(u X)=\left\{Z(f): f \in C_{u}(X)\right\}$ coincides with $Z_{u}=\{Z(f): f \in U(u X)\}$ [7, item (3) of Lemma 2.4]. For the ring $C_{u}^{*}(X) \quad$ of all bounded $u$-continuous functions $\beta_{u} X=H\left(C_{u}^{*}(X)\right)$ and $\mho_{u} X=H\left(C_{u}(X)\right)[7$, Th. 2.8, Th. 2.12].

For an algebra $\mathcal{A}$ on $X$ it has been proved, that $\mathcal{A}=C_{u}(X)(\mathcal{A}=C(X)$ for fine uniformity $u_{f}$ on $X$ ) for some uniformity $u$ on $X$ (Theorem 2.2, Corollaries 2.4, 2.5) and the equality $H\left(\mathcal{A}^{*}\right)=\beta_{u}(H(\mathcal{A})) \quad\left(H\left(\mathcal{A}^{*}\right)=\beta(H(\mathcal{A}))\right.$ ) is fulfilled (Theorem 2.6, Corollary 2.7). Since a ring $C_{u}^{*}(X)\left(C_{v}^{*}(Y)\right)$ is isomorphic to a ring $C\left(H\left(C_{u}^{*}(X)\right)\right)=C\left(\beta_{u} X\right)\left(C\left(H\left(C_{v}^{*}(Y)\right)\right)=C\left(\beta_{v} Y\right)\right)$, it has been proved, that the isomorphism of rings $C_{u}^{*}(X)$ and $C_{v}^{*}(Y)$ is equivalent to the homeomorphism of $\beta-$ like compactifications $\beta_{u} X$ and $\beta_{v} Y$ (Theorem 2.8) and it is equivalent to the $\operatorname{COz}-$ homeomorphism of the uniform spaces $u X$ and $v Y$ with the first countability axiom (Corollaries 2.9, 2.10). For $C O Z$ - fine uniform spaces a similar results for the rings of all bounded uniformly continuous functions have been obtained (Corollary 2.11). Maximal ideals of a ring $C_{u}^{*}(X)$ ( $C_{u}(X)$ ) corresponding to the points of $\beta$ - like compactification $\beta_{u} X$ immediately have been described (Theorem 2.12). From Theorem 2.14, in particular, if it follows, that the isomorphism of rings $C_{u}(X)$ and $C_{v}(Y)$ is equivalent to the homeomorphism of $\beta$-like compactifications $\beta_{u} X$ and $\beta_{v} Y$ and it is equivalent to the $\operatorname{coz}-$ homeomorphism of the uniform spaces $u X$ and with $v Y$ the first countability axiom (Theorem 2.16, Corollaries 2.17, 2.18). As a set of all uniformly continuous functions of $\mathrm{COZ}$ - fine spaces is a ring, so for $\mathrm{COZ}-$ fine spaces the similar results are fulfilled (Corollary 2.19).

A construction of uniformity for realcompactification $v_{u} X$ [7, Th. 2.12] implies a determination of $z_{u}$-complete uniform space (Definition 3.1). Theorem 3.3 establishes the various characterizations of the $z_{u}-$ complete uniform spaces. When $u=u_{f}$ is a maximal uniformity, then $Z_{u_{f}}$ - complete space is a realcompact space [10, Th. 3.11.11]. But on a realcompact nonLindelöf space $X$ there is a uniformity $u$ such that a uniform space $u X$ is not $z_{u}$ - complete (Lemma 3.4, Corollary 3.5), and $z_{u}$ - completeness for any uniformity $u$ is equivalent to Lindelöfness (Theorem 3.6). Theorem 3.7 clarifies Theorem 2.14 [7] and establishes the various characterizations of the realcompactification $v_{u} X$. Theorem 3.8 and Corollaries 3.10, 3.11 are the uniform analogue of Hewitt Theorem [11, 3.12.21 (g)].

Denotations and basic properties of uniform spaces and compactifications from [1, 3, 11, 17, 27]. We denote by $U(u X)\left(U^{*}(u X)\right)$ the set of all (bounded) uniformly continuous functions on the uniform space $u X$. The natural uniformity on $u X$, generated by $U^{*}(u X)$, be $u_{p}$ is the 
smallest uniformity on $X$ with respect to its all functions from $U^{*}(u X)$ are uniformly continuous. Evidently, that $u_{p} \subseteq u$. Samuel compactification $s_{u} X$ is a completion of $X$ with respect to the uniformity $u_{p} \cdot Z_{u}$ is a ring of zero-sets of functions from $U(u X)$ or $U^{*}(u X)$ and $C Z_{u}$ is a ring of cozero-sets of functions from $U(u X)$ or $U^{*}(u X)$. $C Z_{u}$ consists of complements of sets of $Z_{u}$ and, vice versa. We note, that all sets of $C Z_{u}\left(Z_{u}\right)$ coincide with the set of all $u$-open $(u-$ closed $)$ sets in sense of M. Charalambous $[4,5] . Z_{u}$ is the base for closed sets topology and forms s.n.-g.i.r. on $X$ [25], implying that it is a normal base [1, $12,21]$. The topology of a uniform space is generated by its uniformity and in case of compactum $X$ we always use its unique uniformity. The restriction of a uniformity from uniform space $u Y$ to its subspace $X$ is denoted $\left.u\right|_{X}$. A uniform space $u X$ which has a base of all uniform coverings of cardinalities $\leq \tau$ is said to be $\tau-$ bounded [3]. For a uniform space $u X$ its completion is denoted by $\tilde{u} \tilde{X}[3,11,23]$. We denote the set of all natural numbers by $\mathbb{N}, \mathbb{R}$ is the real line, uniformity $u_{\mathbb{R}}$ on $\mathbb{R}$ is induced by the ordinary metric, $\mathbb{Q}$ is the set of rational numbers and $u_{\mathbb{Q}}=\left.u_{\mathbb{R}}\right|_{\mathbb{Q}}$; $I=[0 ; 1]$ is a unit segment; for $X \subset Y$ and a family $F$ of subsets $F$ in $Y$ we denote $X \wedge F=\{X \wedge F: F \in F\}$ and $[X]_{Y}$ be a closure $X$ in $Y$. A sign $\square$ is the end of any proof. A fillter $F$ is said to be countably centered if $\bigcap\left\{F_{n}\right\}_{n \in \mathbb{N}} \neq \varnothing$ for any countable subfamily $\left\{F_{n}\right\}_{n \in \mathbb{N}}$ of the filter $F$. For a fine uniformity $u_{f}$ on Tychonoff space $X[11,23]$ every continuous function is uniformly continuous, hence $U\left(u_{f} X\right)=C(X)$

$\left.{ }_{(} U^{*}\left(u_{f} X\right)=C^{*}(X)\right)$ is the set of all (bounded) continuous functions on $X$ and $Z_{u_{f}}=Z(X)$ is the set of all zero-sets, $C Z_{u_{f}}=C Z(X)$ is the set of all cozero-sets on $X[11,17]$. Every maximal $z_{u}$-filter on $Z_{u}$ is $z_{u}$-ultrafilter. For any function $f \in C(X)$ it is traditionally $Z(f)=f^{-1}(0)$. A covering of $u$-open sets is said to be $u$-open covering and a covering of cozero-sets is said to be cozero covering.

Definition 1.1. A mapping $f: u X \rightarrow v Y$ is said to be $c O z-$ mapping, if $f^{-1}\left(C Z_{v}\right) \subseteq C Z_{u}$ (or $f^{-1}\left(Z_{v}\right) \subseteq Z_{u}$ ) [13, 14]. A mapping $f: u X \rightarrow v Y$ of a uniform space $u X$ into Tychonoff space $Y$ is said to be $z_{u}-$ continuous, if $f^{-1}(C Z(X)) \subseteq C Z_{u}$ (or $\left.f^{-1}(Z(Y)) \subseteq Z_{u}\right)[10]$

Evidently, that every uniformly continuous mapping is a $C O Z-$ mapping and the converse, generally speaking, incorrectly $[4,5]$. Also, every $z_{u}$ - continuous mapping $f: u X \rightarrow Y$ is $c O z-$ mapping of $f: u X \rightarrow v Y$ for any uniformity $v$ on $Y$. 
If $Y$ is Lindelöf or $(Y, \rho)$ is a metric space, then its $C O Z-$ mapping is $z_{u}$ - continuous (see, for example, [4, 5]). If $Y=\mathbb{R}$ or $Y=I$, then the coz - mapping $f: u X \rightarrow \mathbb{R}$ is said to be $u$-continuous function and the $c O z-$ mapping $f: u X \rightarrow I$ said to be $u-$ function $[4,5]$.

We denote the set of all (bounded) $u$-continuous functions on the uniform space $u X$ as $C_{u}(X)\left(C_{u}^{*}(X)\right)$ and $Z(u X)$ be a ring of zero-sets functions from $C_{u}(X)$ or $C_{u}^{*}(X)$ and $C Z(u X)$ consists of complements of sets of $Z(u X)$ and, vice versa.

Definition 1.2. [14] A uniform space $u X$ is said to be Alexandroff space if its each finite $u-$ open covering is uniform.

Definition 1.3. [14] A mapping $f: u X \rightarrow v Y$ is said to be a $C O z-$ homeomorphism, if $f$ is $\operatorname{coz}$ - mapping of $u X$ onto $v Y$ in a one-to-one way, and the inverse mapping $f^{-1}: v Y \rightarrow u X$ is $C O z-$ mapping. A two uniform spaces $u X$ and $v Y$ are $c O z-$ homeomorphic if there exists a $C O Z-$ homeomorphism of $u X$ onto $v Y$.

Definition 1.4. [13, 14] A uniform space $u X$ is said to be $c O Z$ - fine, if each $c O Z-$ mapping $f: u X \rightarrow v Y$ is uniformly continuous.

Theorem 1.5. $[13,14]$ For a uniform space $u X$ the next conditions are equivalent:

(1) $u X$ is a $\mathrm{cOZ}$ - fine space;

(2) if $f$ is $\mathrm{COZ}$ - mapping of $u X$ into a metrizable uniform space $v Y$, then $f: u X \rightarrow v Y$ is uniformly continuous;

(3) $u X$ is a $\mathcal{M}$ - fine and proximally fine space;

(4) $u X$ is separable $\mathcal{M}$ - fine [20] and proximally fine space;

(5) $X$ is a proximally fine Alexandroff space;

(6) for every mapping $f$ of $u X$ into metrizable space $v Y$, if $f: u X \rightarrow v_{p} Y$ is uniformly continuous, then $f: u X \rightarrow v_{f} Y_{\text {is }}$ uniformly continuous, where $v_{f}$ is a fine uniformity on $Y$.

Remark 1.6. Information about of (separable) $\mathcal{M}$ - fine and proximally fine uniform spaces, see, for example, $[13,14,20]$.

\section{Algebra of continuous functions}

Definition 2.1. Let $\mathcal{A}$ be an algebra on $X$. A function $f: X \rightarrow \mathbb{R}$ is said to be $Z(\mathcal{A})$ - continuous, if preimage under $f$ of each closed (open) subset of $\mathbb{R}$ is in $Z(\mathcal{A})$.

For an algebra $\mathcal{A}$ on $X$ we denote by $C_{\mathcal{A}}(X)$ a set of all $Z(\mathcal{A})$ - continuous functions on $X$. Evidently, that $C_{\mathcal{A}}(X) \subset C(X)$.

Theorem 2.2. Let $\mathcal{A}$ be an algebra on $X$. Then on $X$ there is a uniformity $u$ such that $C_{\mathcal{A}}(X)=C_{u}(X)$. 
Proof. Let $u$ be the weakest uniformity on $X$ such that any function of $\mathcal{A}$ is uniformly continuous [23, Ch. I., Th. 3]. Evidently, that $Z_{u}=Z(\mathcal{A})$. The uniformity $u_{\omega}^{z}$ has a base of all countable $u$ - open coverings and $u \subset u_{\omega}^{z}$ [7, Prop. 2.1]. From the item (2) of Lemma 2.4 [7] it follows $C_{\mathcal{A}}(X)=U(u X) \subseteq U\left(u_{\omega}^{z} X\right)=C_{u}(X)$. From the item (3) of Lemma 2.4 [7] it follows, hence, any $u$-continuous function is $Z(\mathcal{A})-$ continuous, i.e. $C_{u}(X) \subseteq C_{\mathcal{A}}(X)$

Remark 2.3. In [19, 6.5 (a)] the statement: "a family $u_{\omega}^{z}$ forms a uniformity", was noted without proof.

Corollary 2.4. Let $\mathcal{A}$ be an algebra on $X$. Then $C_{\mathcal{A}}(X)$ is an algebra on $X$ too.

Proof follows from the equality $C_{\mathcal{A}}(X)=C_{u}(X)$ and Prop. 2.2. [7].

Corollary 2.5. Let $\mathcal{A}$ be an algebra on $X$. Then $\mathcal{A}=C_{\mathcal{A}}(X)$.

Proof. As $C_{\mathcal{A}}(X)=C_{u}(X)$, then $Z(\mathcal{A})=Z(u X)$. Hence from the Theorem 4.3 [24] it follows, that $\mathcal{A}=C_{u}(X)=C_{\mathcal{A}}(X)$.

Theorem 2.6. Let $\mathcal{A}$ be an algebra on $X$. Then $\mathcal{A}=C_{u}(X)$ for some uniformity $u$ on $X$ if and only if $H\left(\mathcal{A}^{*}\right)=\beta_{u}(H(\mathcal{A}))$.

Proof. Let $\mathcal{A}=C_{u}(X)$ for some uniformity $u$ on $X$. Then $\beta_{u} X=H\left(C_{u}^{*}(X)\right)=H\left(\mathcal{A}^{*}\right)$ [7, Th. 2.6 (3)]. From the item (3) of Theorem 2.12 [7] it follows, that $v_{u} X=H(\mathcal{A})$ and $X \subset v_{u} X \subset \beta_{u} X$. Let $Z_{u}^{\prime}=v_{u} X \wedge Z\left(\beta_{u} X\right)$.

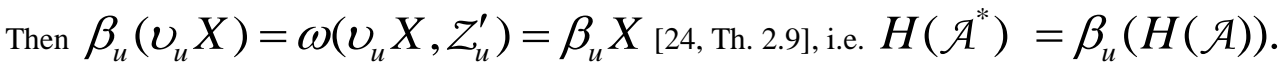

Conversely, let $H\left(\mathcal{A}^{*}\right)=\beta_{u}(H(\mathcal{A}))$ for some uniformity $u$ on $X$. Then $\beta_{u}(H(\mathcal{A}))=\omega\left(X, Z_{u}^{\prime \prime}\right), \quad$ where $\quad Z_{u}^{\prime \prime}=H(\mathcal{A}) \wedge Z\left(H\left(\mathcal{A}^{*}\right)\right) . \quad$ As $Z\left(H\left(\mathcal{A}^{*}\right)\right) \wedge X=Z(\mathcal{A})\left[25\right.$, Th. 2.2], then $Z(\mathcal{A})=X \wedge Z_{u}^{\prime \prime}=Z_{u}$. By Theorem 2.2 and Corollary 2.5 we obtain $\mathcal{A}=C_{u}(X)$.

Compactification $\beta_{u} X$ coincides with Stone-Čech compactification $\beta X$ if and only if $u=u_{f}$ [7]. So, Theorem 2.6. implies the next corollary.

Corollary 2.7. [19, 1.2 (i), (ii)] Let $\mathcal{A}$ be an algebra on $X$. Then $\mathcal{A}=C(X)$ if and only if $H\left(\mathcal{A}^{*}\right)=\beta(H(\mathcal{A}))$.

If $C_{u}^{*}(X)$ and $C_{v}^{*}(Y)$ are isomorphic for a uniform spaces $u X$ and $v Y$, then $H\left(C_{u}^{*}(X)\right)=\beta_{u} X$ and $H\left(C_{v}^{*}(Y)\right)=\beta_{v} Y$ are homeomorphic, and vice versa.

Thus, we have the next theorem. 
Theorem 2.8. For a uniform spaces $u X$ and $v Y$ their compactifications $\beta_{u} X$ and $\beta_{v} Y$ are homeomorphic if and only if $C_{u}^{*}(X)$ and $C_{v}^{*}(Y)$ are isomorphic.

From Theorem 2.5 and Corollaries 2.6, 2.8 of the paper [9] the next results are fulfilled.

Corollary 2.9. Let $u X$ and $v Y$ be the first-countable uniform spaces. Then $u X$ is $c O z-$ homeomorphic to $v Y$ if and only if $C_{u}^{*}(X)$ is isomorphic to $C_{v}^{*}(Y)$.

Corollary 2.10. Let $u X$ and $v Y$ be the first-countable $\mathrm{cOz}$ - fine uniform spaces. Then $u X$ is uniformly homeomorphic to $v Y$ if and only if $C_{u}^{*}(X)$ is isomorphic to $C_{v}^{*}(Y)$.

For $\operatorname{coz}-$ fine uniform spaces $u X$ and $v Y \quad C_{u}^{*}(X)=U^{*}(u X)$ both $C_{v}^{*}(Y)=U^{*}(v Y)[13,14]$ and rings $U^{*}(u X), U^{*}(v Y)$ are isomorphic to the rings $U^{*}(\tilde{u} \tilde{X}), U^{*}(\tilde{v} \tilde{Y})$, respectively.

Corollary 2.11. Let $u X$ and $v Y$ be a complete the first-countable coz-fine uniform spaces. Then $u X$ is uniformly homeomorphic to $v Y$ if and only if $U^{*}(u X)$ is isomorphic to $U^{*}(v Y)$.

For $C_{u}^{*}(X)$ we can utilize the ring isomorphism $f \mapsto \beta_{u} f$ of $C_{u}^{*}(X)$ and $C^{*}\left(\beta_{u} X\right)$ [7, Th. 2.8(4)] to characterize the maximal ideals of $C_{u}^{*}(X)$ in $\beta_{u} X$ terms.

Theorem 2.12. The maximal ideals of $C_{u}^{*}(X)$ are in the one-to-one correspondence with the points of $\beta_{u} X$ and are given $I_{p}^{*}=\left\{f \in C^{*}(X): \beta_{u} f(p)=0\right\}$ for $p$ is a point of $\beta_{u} X$

For the relate $z_{u}$ - filteres and $z_{u}$-ultrafilteres to the ring $C_{u}(X)$ we consider the mapping $Z: C_{u}(X) \rightarrow Z_{u}\left(Z(f)=f^{-1}(0) \in Z_{u}\right.$ for $\left.f \in C_{u}(X)\right)$. The next result is analogue $[17,2.3]$ and shows that the image of an ideal (maximal ideal) under $\mathrm{Z}$ is a $Z_{u}-$ filter $\left(z_{u}-\right.$ ultrafilter $)$ and that the preimage of a $z_{u}-$ filter $\left(z_{u}-\right.$ ultrafilter $)$ is an ideal (maximal ideal).

Proposition 2.13. (a) If $I$ is a proper (maximal) ideal in $C_{u}(X)$, then $Z(I)=\{Z(f): f \in I\}$ is a $z_{u}-$ filter $\left(z_{u}-\right.$ ultrafilter $)$ on $u X$.

(b) If $F$ is a $z_{u}$-filter $\left(z_{u}\right.$-ultrafilter $)$ on $u X$, then $Z^{-1}[F]=\left\{f \in C_{u}(X): Z(f) \in F\right\}$ is an (maximal) ideal in $C_{u}(X)$.

Theorem 2.14. The maximal ideals of $C_{u}(X)$ are in the one-to-one correspondence with the points of $\beta_{u} X$ and are given

$$
I_{p}=\left\{f \in C_{u}(X): p \in[Z(f)]_{\beta_{u} X}\right\} \text { for } p \text { is a point of } \beta_{u} X .
$$

Proof. It is analogically to the proof of Theorem 1.30 [27]. 
Corollary 2.15. A compactification $\beta_{u} X$ is homeomorphic to the space $\mathcal{M}(u X)$ of maximal ideals of the ring $C_{u}(X)$.

Proof. $\square$ It is analogically to the proof of Corollary 1.31 [27].

Theorem 2.16. For a uniform spaces $u X$ and $v Y$ their compactifications $\beta_{u} X$ and $\beta_{v} Y$ are homeomorphic if and only if $C_{u}(X)$ and $C_{v}(Y)$ are isomorphic.

Corollary 2.17. Let $u X$ and $v Y$ be the first-countable uniform spaces. Then $u X$ is cozhomeomorphic to $v Y$ if and only if $C_{u}(X)$ is isomorphic to $C_{v}(Y)$.

Corollary 2.18. Let $u X$ and $v Y$ be the first-countable coz-fine uniform spaces. Then $u X$ is uniformly homeomorphic to $v Y$ if and only if $C_{u}(X)$ is isomorphic to $C_{v}(Y)$.

For coz-fine uniform spaces $u X \quad$ and $v Y \quad C_{u}(X)=U(u X) \quad$ and $C_{v}(Y)=U(v Y)[13,14]$ and the rings $U(u X), U(v Y)$ are isomorphic to the rings $U(\tilde{u} \tilde{X}), U(\tilde{v} \tilde{Y})$, respectively.

Corollary 2.19. Let $u X$ and $v Y$ be a complete the first-countable cOz-fine uniform spaces. Then $u X$ is uniformly homeomorphic to $v Y$ if and only if $U(u X)$ is isomorphic to $U(v Y)$.

Remark 2.20. Note, that Theorem 2.12 is a uniform analogue of Stone Theorem [26] and Theorem 2.14 is a uniform analogue of Gelfand-Kolmogoroff Theorem [15].

\section{On $z_{u}$ - complete uniform spaces.}

Definition 3.1. A uniform space $u X$ is said to be $z_{u}$-complete if it is cOZhomeomorphic to a closed uniform subspace of a power of $\mathbb{R}$.

Remark 3.2. By analogue with [16], an ideal $I \subset C_{u}(X)$ is said to be fixed, if $\bigcap Z(I)=\bigcap\{Z(f): f \in I\} \neq \varnothing$ and if $Z(I)$ is a countably centered $z_{u}-$ ultrafilter, then a maximal ideal $I$ is said to be real ideal.

Theorem 3.3. For uniform space $u X$ the following conditions are equivalent:

(1) $u X$ is $z_{u}-$ complete;

(2) $X$ is complete with respect to the uniformity $u_{\omega}^{z}$;

(3) $u X=\beta_{u} X$;

(4) each countably centered $z_{u}$ - ultrafilter is convergent;

(5) each point in $X$ is the limit of the unique countably centered $z_{u}$-ultrafilter on $u X$.

(6) every real maximal ideal in $C_{u}(X)$ is fixed.

Proof. $(1) \Rightarrow(2)$. Let $i: u X \rightarrow \mathbb{R}^{\tau}$ be a $\operatorname{coz}$ - homeomorphism of the uniform space $u X$ onto a closed uniform subspace $X^{\prime}=i(X) \subset \mathbb{R}^{\tau}$ with the uniformity $u^{\prime}=\left.u_{\mathbb{R}}^{\tau}\right|_{i(X)}$, where $\mathbb{R}^{\tau}\left(\boldsymbol{u}_{\mathbb{R}}^{\tau}\right)$ is a power of $\mathbb{R}\left(\boldsymbol{u}_{\mathbb{R}}\right)$. A uniform space $\boldsymbol{u}_{\mathbb{R}} \mathbb{R}$ is $\aleph_{\mathbf{0}}$ - bounded and 
complete [3], hence $u^{\prime} X^{\prime}$ is also $\aleph_{0}$ - bounded and complete [3]. Then $X^{\prime}$ is complete with respect to the uniformity $u_{\omega}^{\prime z}$ (see Proposition 2.1 [7]). From the item (1') of Lemma 2.4 [7], it follows, that the uniform spaces $u_{\omega}^{z} X$ and $u_{\omega}^{\prime z} X^{\prime}$ are uniformly homeomorphic, so $X$ is complete with respect to the uniformity $u_{\omega}^{z}$.

$(2) \Leftrightarrow(3)$. It follows from items (1), (2) of Theorem 2.12 [7].

$(3) \Leftrightarrow(4) \Leftrightarrow(5)$. It follows from items (1), (8) of Theorem 2.14 [7].

$(5) \Leftrightarrow(6)$. It is obvious, (see Remark 3.2).

$(2) \Rightarrow(1) . \quad$ Let $\left|C_{u}(X)\right|=\tau . \quad$ By $\quad$ the $\quad$ item $\quad 2 \quad$ of Lemma 2.4 [7], $C_{u}(X)=U\left(u_{\omega}^{z} X\right)$, hence, the uniform space $u_{\omega}^{z} X$ is uniformly homeomorphically

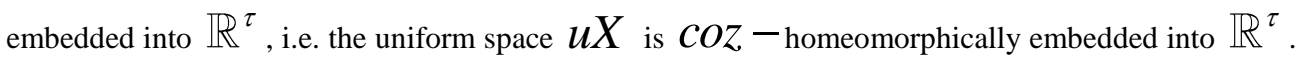

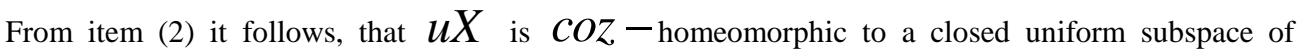
$u_{\mathbb{R}}^{\tau} \mathbb{R}^{\tau}$

Lemma 3.4. [24] If $p \subset Z(X)$ is a filter closed under countable intersections and $\cap p=\varnothing$, then on Tychonoff space $X$ there is a base for closed sets, which is s.,n.-g.i.r. and there is a uniformity $u$ such, that $p \in v_{u} X$.

Proof. [25, Lemma 3.5]. We put $F=\{Z \in Z(X): Z \in p$ or $Z \cap P=\varnothing$ for some $P \in p\}$. Then $F$ is s.,n.-g.i.r. and the Wallman compactification $\omega(X, F)$ is $\beta$ - like [24] compactification. All countable cozero coverings, consisting of the elements of family $C F=\{X \backslash Z: Z \in F\}$, form the uniformity $u$ on $X$ [7, Prop. 2.1]. Therefore, $\omega(X, F)=\beta_{u} X, v(X, F)=v_{u} X$ and $p$ is a free countably centered $z_{u}-$ ultrafilter on the uniform space $u X$, i.e. $p \in v_{u} X$.

Corollary 3.5. If $X$ is a realcompact and non-Lindelöf space, then there exists a uniformity $u$ on $X$ such, that $u X$ is not $z_{u}$ - complete.

Proof. If $X$ is a realcompact and non-Lindelöf, then there is a filter $p \subset Z(X)$ closed under countable intersections and $\cap p=\varnothing[11,3.8 .3]$. By Lemma 3.4, on $X$ there exists a uniformity $u$ such, that $X \neq v_{u} X$, i.e. the uniform space $u X$ is not $z_{u}$ - complete.

The next theorem characterizes the Tychonoff Lindelöf spaces by means of uniform structures.

Theorem 3.6. Tychonoff space $X$ is Lindelöf if and only if $u X$ is $z_{u}$-complete for any uniformity $u$ on $X$.

Proof. If Tychonoff space $X$ is Lindelöf, then, evidently, that $u X$ is $z_{u}$ - complete ([11,3.8.3], item (2) of Theorem 3.3).

Let $u X$ be $z_{u}-$ complete for any uniformity $u$ on the Tychonoff space $X$. We assume, that $X$ is non-Lindelöf space. Then on $X$ there is a filter $p \subset Z(X)$ closed under countable 
intersections such, that $\cap p=\varnothing[10,3.8 .3]$. Then, by Lemma 3.4, on $X$ there is a uniformity $u$ such that $X \neq v_{u} X$, i.e. the uniform space $u X$ is not $z_{u}-$ complete. Contradiction.

The next theorem characterizes the Wallman realcompactifications.

Theorem 3.7. For a Wallman realcompactifications $\cup_{u} X$ the following conditions are equivalent:

(1) $\bigcup_{u} X$ is an intersection of all cozero-sets in $\beta_{u} X$ which contains $X$;

(2) $v_{u} X$ is a completion of $X$ with respect to $u_{\omega}^{z}$;

(3) any $\mathrm{COZ}-$ mapping $f: u X \rightarrow v Y$ into a $z_{u}-$ complete uniform space $v Y$ has a uniformly continuous extension $v_{u} f: v_{u} X \rightarrow v Y$;

(4) any $u$-continuous function $f: u X \rightarrow u_{\mathbb{R}} \mathbb{R}$ has a uniformly continuous extension $v_{u} f: v_{u} X \rightarrow u_{\mathbb{R}} \mathbb{R}$

(5) If a countable $u-$ closed sets family in $u X$ has empty intersection, then their closures in $\cup_{u} X$ have empty intersection.

(6) The equality $\left[\bigcap_{i \in \mathbb{N}} Z_{i}\right]_{u X}=\bigcap_{i \in \mathbb{N}}\left[Z_{i}\right]_{u X}$ is fulfilled for any countable family of $u-$ closed sets $\left\{Z_{i}\right\}_{i \in \mathbb{N}}$ in $u X$.

(7) each point of $\bigcup_{u} X$ is the limit of the unique countably centered $z_{u}-$ ultrafilter on $u X$.

Proof. (1) $\Leftrightarrow(2)$. It follows by the items (1), (3) of Theorem 2.12 [7].

$(2) \Rightarrow(3)$. Let $f: u X \rightarrow v Y$ be an arbitrary $c O z-$ mapping of uniform space $u X$ into the $z_{v}$-complete uniform space $v Y$. By the item (1') of Lemma 2.4 [7] the mapping $f: u_{\omega}^{z} X \rightarrow v_{\omega}^{z} Y$ is uniformly continuous. As $v_{\omega}^{z} Y$ is a complete uniform space the mapping $f$ can be uniformly continuously extended over $v_{u} X$ to the mapping $v_{u} f: v_{u} X \rightarrow v Y$.

$(3) \Rightarrow(4)$. It is obvious, as $u_{\mathbb{R}} \mathbb{R}$ is $z_{u_{\mathbb{R}}}$ - complete.

$(4) \Rightarrow(5)$. From Definition 2.10 [7] and Theorem 2.14 for any $u$-continuous function $f \in C_{u}(X) \mathrm{Z}\left(v_{u} f\right)=[\mathrm{Z}(f)]_{v_{u} X}$ is fulfilled. Let $Z_{i}=f_{i}^{-\mathbf{1}}(0) ; i \in \mathbb{N}$, and $\bigcap\left\{Z_{i}\right\}_{i \in \mathbb{N}}=\varnothing$. Then $\alpha=\left\{X \backslash Z_{i}\right\}_{i \in \mathbb{N}} \quad$ is a countable $u$-open covering and $\alpha \in u_{\omega}^{z}$ and for a system $E x_{u} \alpha=\left\{E x_{u}\left(X \backslash Z_{i}\right)\right\}_{i \in \mathbb{N}} \quad$ by the item $\bigcup E x_{u} \alpha=v_{u} X \quad$ is $\quad$ fulfilled, where $E x_{u}\left(X \backslash Z_{i}\right)=v_{u} X \backslash\left[Z_{i}\right]_{v_{u} X}=v_{u} X \backslash Z\left(v_{u} f\right)$. Suppose $p$ be a countably centered $z_{u}-$ ultrafilter such that $p \in v_{u} X \backslash \bigcup E x_{u} \alpha$. Then $p \notin E x_{u}\left(X \backslash Z_{i}\right)$, hence, $p \in Z\left(v_{u} f_{i}\right)=\left[\mathrm{Z}\left(f_{i}\right)\right]_{v_{u} X}$, i.e. $Z_{i}=\mathrm{Z}\left(f_{i}\right) \in p$ for all $i \in \mathbb{N}$. We obtain 
a contradiction, as $\bigcap_{i \in \mathbb{N}} Z_{i} \neq \varnothing$. So, $E x_{u} \alpha$ is a uniform covering of $v_{u} X$. Thus, $\bigcup E x_{u} \alpha=v_{u} X$ or $\bigcap_{i \in \mathbb{N}}\left[Z_{i}\right]_{v_{u} X}=\varnothing$.

$(5) \Rightarrow(6)$. It is obvious.

$(6) \Rightarrow(7)$. It is obvious.

$(7) \Leftrightarrow(2)$. From Lemma 2.11 [7].

Theorem 3.8. If $u X$ and $v Y$ are $z_{u}$ - and $z_{v}$ - complete uniform spaces, respectively. Then $u X$ is coz - homeomorphic to $v Y$ if and only if $C_{u}(X)$ and $C_{v}(Y)$ are isomorphic.

Proof. If a $Z_{u}$ - complete uniform space $u X$ is $C O Z$ - homeomorphic to $Z_{v}$ - complete uniform space $v Y$, then the rings $C_{u}(X)$ and $C_{v}(Y)$ are isomorphic. It is obvious.

Let the rings $C_{u}(X)$ and $C_{v}(Y)$ be isomorphic. We fix an isomorphism $i: C_{u}(X) \rightarrow C_{v}(Y)$. Then an isomorphism $i$ induces a homeomorphism $\bar{i}: H\left(C_{u}^{*}(X)\right) \rightarrow H\left(C_{v}^{*}(Y)\right)$. Each point $x \in X$ is identically with unique countably centered real $z_{u}$-ultrafilter $p_{x}$ (item (6'), Th.3.7), which corresponds to the maximal real ideal $I_{u} \in H\left(C_{u}^{*}(X)\right)$. Then $i\left(I_{u}\right)=I_{y}$ is a maximal real ideal of $H\left(C_{v}^{*}(Y)\right)$, and vice versa. Thus, under an isomorphism all maximal real ideals of the ring $C_{u}(X)$ are transferring into the maximal real ideals of the ring $C_{v}(Y)$, and vice versa. Then $\left.\bar{i}\right|_{X}: u_{p}^{z} X \rightarrow v_{p}^{z} Y$ is uniform homeomorphism, where $u_{p}^{z}, v_{p}^{z}$ (see [7, Prop.2.1]) are the Wallman precompact uniformities [7, Remark 2.9] on $X$ and $Y$, respectively. As $Z_{u}=Z_{u_{p}^{z}}$ and $Z_{v}=Z_{v_{p}^{z}}$ [7, Lemma 2.4(3)], then the uniform spaces $u X$ and $v Y$ are $C O Z$ - homeomorphic.

Remark 3.9. Every fixed maximal real ideal $I_{x}$ of a ring $C_{u}(X)$ corresponds to a fixed maximal real ideal $I_{x} \bigcap C_{u}^{*}(X)$ of a ring $C_{u}^{*}(X)$ and this correspondence is one-to-one (it can be prove similar to $[17,4.7])$.

Remark 3.10. For the uniformity $u_{\omega}^{z}$ of uniform space $u X$ the equalities $\tilde{u}_{\omega}^{z} \tilde{X}=v_{u} X$ [7, Th. 2.12(1)] and $v_{u} X=\omega\left(\beta_{u} X, Z\left(\beta_{u} X\right) \wedge v_{u} X\right)$ [25, Th.2.9, Th.3.9] are fulfilled, hence, Wallman realcompactifications of $u_{\omega}^{z} X$ and $\tilde{u}_{\omega}^{z} \tilde{X}$ coincide. By item (4) of Lemma 2.4 [7] for separable $\mathcal{M}$ - fine uniform space $u X \quad[18] \quad u=u_{\omega}^{z} \quad$ and $C_{u}(X)=U(u X)=U(\tilde{u} \tilde{X})$. Thus, it takes place

Corollary 3.11. If $u X$ and $v Y$ are complete separable $\mathcal{M}$-fine uniform spaces. Then $u X$ is uniformly homeomorphic to $v Y$ if and only if $U(u X)$ and $U(v Y)$ are isomorphic. 


\section{References}

1. Aarts J.M., Nishiura T. Dimension and Extensions. North-Holland, 1993. 331 p.

2. Arhangel'skii A.V., Ponomarev V.I. Fundamentals of General Topology: Problems and Exercises,Reidel, translated from Russian, 1984. 423 p.

3. Borubaev A.A., Chekeev A.A., Pankov P.S. Spaces uniformed by coverings, Bishkek-Budapest, 2003. $170 \mathrm{p}$.

4. Charalambous M.G. A new covering dimension function for uniform spaces. J. London Math. Soc. 2(11), 1975. P. 137-143.

5. Charalambous M.G. Further theory and applications of covering dimension of uniform spaces, Czech. Math. J. 41 (116), 1991. P. 378-394.

6. Čech E. On bicompact spaces, Ann. Of Mat. 38, 1937. P. 823-844.

7. Chekeev A.A. Uniformities for Wallman compactifications and realcompactifications. Topol. Appl. V. 201, 2016. P. 145-156.

8. Chekeev A.A., Kasymova T.J. Ultrafilter-completeness on zero-sets of uniformly continuous functions // TOPOSYM - 2016, 25-29 July (Prague, Czech Republic), Topology Atlas, 2016. P. 76 (to appear).

9. Chekeev A.A., Rakhmankulov B.Z. On $\beta$-like compactification and inversion-closed rings of uniform spaces //Вестник науки и образования, 2016. №6 (18). P. 6-14. (in Russian).

10. Chigogidze A.Ch., Relative dimensions, Gen. Topol. Spaces of functions and dimension, Moscow: MSU, 1985. P. 67-117 (in Russian).

11. Engelking R., General Topology, Berlin: Heldermann, 1989. 515 p.

12. Frink O. Compactifications and seminormal spaces, Amer. J. Math., 86, 1964. P. 602-607.

13. Frolik Z. A note on metric-fine spaces, Proc. Amer. Math.Soc. V. 46, n. 1, 1974. P. 111-119.

14. Frolik Z. Four functor into paved spaces, in seminar uniform spaces 1973-4. Matematicky ustav USAV, Praha, 1975. P. 27-72.

15. Gelfand J., Kolmogoroff A. On rings of continuous function on topological spaces, Dokl. Akad. Nauk SSSR 22, 1939. P. 11-15. (in Russian)

16. Georgiou D.N., Iliadis S.D., Kozlov K.L., The covering dimension invariants, Topology Appl., 159 (9), 2012. P. 2392-2403.

17. Gillman L., Jerison M. Rings of continuous functions, The Univ. Series in Higher Math., Van Nostrand, Princeton, N. J., 1960. 303 p.

18. Hager A.W., Johnson D.J. A note on certain subalgebras of C(X), Canad. J. Math. 20, 1968. P. 389-393.

19. Hager A.W. On inverse-closed subalgebra of C(X), Proc. Lond. Math. Soc. 19(3), 1969. P. 233257.

20. Hager A.W. Some nearly fine uniform spaces, Proc. London Math. Soc. 3(28), 1974. P. 517-546.

21. Iliadis S.D. Universal spaces and mappings, North-Holland Mathematics Studies, 198. Elsevier Science B.V., 2005. Amsterdam. 559 p.

22. Isbell J.R. Algebras of uniformly continuous functions, Ann. of Math., 68, 1958. P. 96-125.

23. Isbell J.R. Uniform spaces, Providence, 1964. 175 p.

24. Mrówka S. $\beta$-like compactifications, Acta Math. Acad. Sci. Hungaricae, 24 (3-4), 1973. P. 279287.

25. Steiner A.K., Steiner E.F. Nest generated intersection rings in Tychonoff spaces, Trans. Amer. Math. Soc. 148, 1970. P. 589-601.

26. Stone M. Applications of the theory of Boolean rings to general topology, Trans. Amer. Math. Soc. 41, 1937. P. 375-481.

27. Walker R. The Stone-Čech compactification, Springer-Verlag, New York, Berlin, 1974. 333 p. 


\title{
ЧИСЛЕННЫЕ ЭКСПЕРИМЕНТЫ ДЛЯ ВЫЯВЛЕНИЯ ЭФФЕКТА АНАЛИТИЧНОСТИ \\ Аскар кызы Л. ${ }^{1}$, Кененбаева Г.М. ${ }^{2}$ Email: Askar1791@scientifictext.ru
}

\author{
${ }^{1}$ Аскар кызы Лира - стариий преподаватель, \\ кафедра прикладной математики, информатики и информационных технологий, \\ факультет математики и информатики, \\ Кыргызский национальный университет им. Ж. Баласагына; \\ ${ }^{2}$ Кененбаева Гулай Мекишовна - доктор физико-математических наук, дочент, ведущий научный \\ сотрудник, \\ Институт теоретической и прикладной математики, \\ Национальная академия наук Кыргызской Республики, \\ 2. Бишкек, Кыргызская Республика
}

\begin{abstract}
Аннотация: ранее авторами доказано, что линейные интегральные уравнения первого рода могут быть корректными в некоторых классах аналитических функиий, и выявлен эффект «аналитичности» для интегральных уравнений первого рода. Также говорится о наличии в математике «эффекта аналитичности» - задачи из различных разделов математики, которые являются некорректными в классах непрерывных и гладких функций, становятся корректными в некоторых классах аналитических функиий. В данной статье численно выявлены эффекты аналитичности дифференциальных уравнений первого порядка в частных производных с аналитическими данными. Приводятся результаты численных экспериментов, показывающие, что многие задачи для дифференциальных уравнений первого и второго порядка с аналитическими данными являются корректно поставленными.

Ключевые слова: интегральное уравнение первого рода, линейное уравнение, аналитическая функиия, корректность, эффект «аналитичности», дифференциальное уравнение первого порядка в частных производных.
\end{abstract}

\author{
NUMERICAL EXPERIMENTS TO DETERMINE THE EFFECT \\ ANALYTICITY \\ Askar kyzy L. ${ }^{1}$, Kenenbaeva G.M. ${ }^{2}$ \\ ${ }^{1}$ Askar kyzy Lira - senior lecturer, \\ DEPARTMENT APPLIED MATHEMATICS, INFORMATICS AND INFORMATION TECHNOLOGIES, \\ FACULTY OF MATHEMATICS AND INFORMATICS, \\ KYRGYZ NATIONAL UNIVERSITY. J. BALASAGYN; \\ ${ }^{2}$ Kenenbaeva Gulai Mekishovna - doctor of physico-mathematical Sciences, associate Professor, leading \\ researcher, \\ INSTITUTE OF THEORETICAL AND APPLIED MATHEMATICS, \\ NATIONAL ACADEMY OF SCIENCES OF THE KYRGYZ REPUBLIC, \\ BISHKEK, REPUBLIC OF KYRGAZSTAN
}

\begin{abstract}
: earlier, the authors proved that linear integral equations of the first kind might be correct in some classes of analytical functions. In this article, the effects identified numerically analytic differential equations of the first order partial derivatives with analytical data. Also in mathematics "effect of analyticity" - tasks from different branches of mathematics are incorrect in classes of continuous and smooth functions, are valid in some classes of analytic functions. This article numerically identified effects of the analyticity of differential equations first order equations with analytical data. The results of numerical experiments showing that many of the tasks for differential equations first and second order with analytical data are correctly delivered.

Keywords: integral equation of the first kind, linear equation, analytical function, correctness, the effect of "analytic", the differential equation of the first order partial derivatives.
\end{abstract}

\section{Введение}

На основе анализа работ [1] - [3] с помощью методики [4] авторы сделали вывод о наличии в математике «эффекта аналитичности» - задачи из различных разделов математики, которые являются некорректными в классах непрерывных и гладких функций, становятся корректными в некоторых классах аналитических функций. В работах упомянутых авторов это были задачи из различных разделов теории дифференциальных уравнений. 
Нами были рассмотрены с данной точки зрения задачи теории интегральных уравнений. Было найдено следующее необходимое условие корректности задач для линейных интегральных уравнений первого рода.

Известно, что интегральный оператор Фредгольма с непрерывным ядром на ограниченном отрезке $\Delta$ является вполне непрерывным, то есть он переводит любую ограниченную последовательность функций в сходящуюся по норме пространства $C(\Delta)$. Следовательно, задача решения линейного интегрального уравнения первого рода типа Фредгольма с заданной правой частью - непрерывной функцией - не может быть корректно поставлена. Таким образом, корректной может быть только задача решения линейного интегрального уравнения первого рода на неограниченной области $\Delta$.

1. Применение метода сеток к дифференциальному уравнению первого порядка в частных производных с аналитическими данными

Рассматривается уравнение вида

с начальным условием

$$
u_{y}^{\prime}(x, y)=g\left(u_{x}^{\prime}(x, y), u(x, y), x, y\right) \quad\left(x \in R, y \in R_{+}\right),
$$

$$
u(x, 0)=\varphi(x) \quad(x \in \mathrm{R}),
$$

где $g(w, u, x, y), \varphi(x)$ - аналитические по своим переменным функции, вещественные для вещественных значений аргументов.

Если эти функции - только непрерывны, то, согласно известным результатам, значения функции $u(x, y)$ определяются такими значениями функции $\varphi(x)$, что точки $(x, 0)$ и $(x, y)$ связаны направлением характеристик.

Были проведены следующие эксперименты.

Выбирается малое число $h>0$ - шаг по $y$. Рассматривается явная разностная схема наиболее общего вида

где $L_{h}$ - некоторый разностный оператор.

$$
u(x, y+h)=L_{h} u(x, y)
$$

Построена сетка:

$Y[k]:=k h, k \in N_{0}, \Phi[j]:=\varphi(X[j])$,

$$
X[j]:=x_{0}+j h, j \in \boldsymbol{Z},
$$

$U[j, k]$ - приближенное значение $u(X[j], Y[k])$.

Тогда разностная схема (с правыми разделенными разностями) имеет вид:

$$
U[j, k+1]=U[j+1, k]+h \cdot g\left(\frac{U[j, k+1]-U[j, k]}{h}, U[j, k], X[j], Y[k]\right), j \in Z,
$$

с начальными условиями

$$
U[j, 0]=\Phi[j], j \in \mathbf{Z} .
$$

Для приближенного вычисления $u\left(x_{e}, y_{e}\right)$ по заданным функциям $\varphi(x), g(w, u, x, y)$, числам $x_{e} \in \mathrm{R}, y_{e}>0$ и количеству шагов $n$ построен следующий

АЛГОРИТМ 1. Объявляются массивы

$X[j], Y[j]), U_{\text {old }}[j], U_{\text {new }}[j], j=0 . . n$.

А) Вычислить $h:=y_{e} / n$.

Б) Цикл по $k=0 . . n$

$\left\{\right.$ Вычислить $X[k]:=x_{e}+k * h, Y[k]:=k * h, U_{\text {old }}[k]:=\varphi(X[k])$

В) Цикл по $k=1 . . n$

Цикл по $j=0 . . n-k$ :

$\left\{U_{\text {new }}[j]:=U_{\text {old }}[j]+h * g\left(\left(U_{\text {old }}[j+1]-U_{\text {old }}[j]\right) / h, U_{\text {old }}[j], X[j], Y[k]\right)\right\}$

Г) Цикл по $j=0 . . n-k$ :

$\left\{U_{\text {old }}[j]:=U_{\text {new }}[j]\right\}$

\}

Д) Вывести значение $U_{\text {old }}[n]$ (приближенно равное $u\left(x_{e}, y_{e}\right)$ ).

Е) Конец.

ПРИМЕР 1. Расчет для квазилинейного уравнения

$u_{y}^{\prime}(x, y)=-u(x, y) u_{x}{ }^{\prime}(x, y)+2 x^{3}+2 x y^{2}+2 y, u(x, 0)=x^{2}\left(u(x, y)=x^{2}+y^{2}\right)$

$\mathrm{c} n=64, h=\frac{1}{64}$ дал результат $u(0,1) \approx 1.082$ (точное значение $=1$ ). 
ПРИМЕР 2. Расчет для существенно нелинейного уравнения

$u_{y}^{\prime}(x, y)=-\left(u_{x}^{\prime}(x, y)\right)^{2}+4 x^{2}+2 y, u(x, 0)=x^{2}\left(u(x, y)=x^{2}+y^{2}\right)$

$\mathrm{c} n=32, h=\frac{1}{32}$ дал результат $u(0,1) \approx 1.031$ (точное значение $=1$ ).

ПРИМЕР 3. Расчет для уравнения с неполиномиальной нелинейностью

$u_{y}{ }^{\prime}(x, y)=-\sqrt{u_{x}{ }^{\prime}(x, y)}+2 x^{2} y+\sqrt{2 x y^{2}+1}, \quad u(x, 0)=x\left(u(x, y)=x+x^{2} y^{2}\right)$

c $n=32, h=\frac{1}{16}$ дал результат $u(1,2) \approx 5.142$ (точное значение $=5$ ).

Таким образом, во всех случаях метод сеток дал приемлемые результаты, независимо от наличия и направления характеристик.

Еще пример с известным решением:

ПРИМЕР 4. Рассмотрено уравнение

$$
u_{y}^{\prime}(x, y)+q(y) u_{x}^{\prime}(x, y)=0, q(y)>0 \quad\left(x \in R, y \in R_{+}\right),
$$

с начальным условием (2), где $q(y)$ - аналитическая функция, вещественная и положительная для вещественныху.

Его точное решение

$$
u(x, y)=\varphi\left(x-\int_{0}^{y} q(s) d s\right)
$$

то есть определяется значениями функции $\varphi$ с аргументом, меньшим $x$.

С использованием Алгоритма 1 (с уточнением), была составлена система разностных уравнений с правыми разделенными разностями по $x$, то есть для приближенного вычисления $u(x, y)$ использовались значения функции $\varphi$ с аргументом, большим, чем $x$. Для повышения точности при вычислении $U[j, k+1]$ было взято значение функции $q(y)$ в средней точке отрезка

$(X[j], Y[k])-(X[j], Y[k+1])$.

Выведена расчетная формула

$$
\begin{array}{r}
U[j, k+1]=L_{\text {прав. }} U:=U[j, k]-q(Y[k]+h / 2)(U[j+1, k]-U[j, k]) \\
\left(j \in \mathrm{Z}, k \in \mathrm{N}_{0}\right),
\end{array}
$$

с начальным условием (6).

Было выбрано $q(y)=1+2 y, \varphi(x)=x^{2}$, тогда

$$
\left.u(x, y)=\left(x-\int_{0}^{y}(1+2 s) d s\right)\right)^{2}=\left(x-y-y^{2}\right)^{2} .
$$

Вычислялись значения $u(0,1)=4, u(0,2)=36$.

Были получены следующие результаты.

Таблица 1. Результаты расчета с правой разделенной разностью (значения начальной функции берутся со стороны, противоположной характеристике)

\begin{tabular}{|l|l|l|l|l|l|}
\hline $\boldsymbol{h}$ & $\mathbf{1 / 4}$ & $\mathbf{1 / 8}$ & $\mathbf{1 / 1 6}$ & $\mathbf{1 / 3 2}$ & $\mathbf{1 / 6 4}$ \\
\hline$u(0,1) \approx$ & 2.44 & 3.21 & 3.60 & 3.80 & $\infty$ \\
\hline$u(0,2) \approx$ & 29.34 & 32.67 & 34.33 & $\infty$ & $\infty$ \\
\hline
\end{tabular}

Знаком $\infty$ обозначается переполнение.

Таким образом, имеет место сходимость, хотя и не быстрая, к точному значению.

Для сравнения был также произведен расчет по формуле

$U[j, k+1]=L_{\text {лев. }} U:=U[j, k]-q(Y[k]+h / 2)(U[j, k]-U[j-1, k])$

$(j \in Z, k \in \mathrm{N})$.

Студентами Кыргызско-Российской Академии Образования был также произведен расчет для других примеров. 
Таблица 2. Результаты расчета с левой разделенной разностью (значения начальной функции берутся со стороны характеристики)

\begin{tabular}{|c|c|c|c|c|c|c|}
\hline $\boldsymbol{h}$ & $\mathbf{1 / 4}$ & $\mathbf{1 / 8}$ & $\mathbf{1 / 1 6}$ & $\mathbf{1 / 3 2}$ & $\mathbf{1 / 6 4}$ & $\mathbf{1 / 1 2 8}$ \\
\hline$u(0,1) \approx$ & 3.42 & 3.71 & 3.85 & 3.93 & 3.96 & $\infty$ \\
\hline$u(0,2) \approx$ & 32.34 & 34.17 & 35.08 & $\infty$ & $\infty$ & $\infty$ \\
\hline
\end{tabular}

Таким образом, подтвержден и эффект аналитичности, и влияние характеристики: расчет в области, более близкой к характеристике, является более эффективным.

\title{
Сиисок литературы / References
}

1. Кененбаева Г.М. Эффект аналитичности для дифференциальных и интегральных уравнений. Saarbrücken, Deutschland: LAP Lambert Academic Publishing, 2015. 64 c.

2. Pankov P.S., Imanaliev T.M. Convergence of Finite Difference Method for First-Order Partial Differential Equations with Analytical Initial Conditions // Analytical and Approximate Methods:

3. International Conference at the Kyrgyz-Russian Slavic University. Shaker Verlag, Aachen, Germany, 2003. Pp. 185-193.

4. Панков П.С., Сабирова Х.С. Применение метода сеток к обратной начальной задаче для уравнения теплопроводности с аналитическим начальным условием // Вестник КНУ им. Ж. Баласагына: Естественно-технические науки. Серия 3. Вып. 3. Математические науки. Информатика и информационные технологии, 2005. С. 103-106.

5. Кененбаева Г.М. Теория и методика поиска новых эффектов и явлений втеории возмущенных дифференциальных и разностных уравнений. Бишкек: Изд-во «Илим», 2012. $204 \mathrm{c}$.

6. Манжиров А.В., Полянин А.Д. Справочник по интегральным уравнениям: Методы решения. Москва: Изд-во «Факториал Пресс», 2000. 384 с. Раздел 4.3-1.

7. Панков П.С., Сабирова Х.С. Корректность обратной начальной задачи для уравнения теплопроводности с аналитическими данными // Дифференциальные уравнения в частных производных и родственные проблемы анализа и информатики: Труды международной научной конференции (г. Ташкент, 16 - 19 ноября 2004). Том 1. Ташкент, 2004. С. 117-121.

8. Кененбаева Г.М., Аскар кызы Л. Класс интегральных уравнений первого рода, имеющих решение при любой правой части // Актуальные проблемы вычислительной и прикладной математики: труды Международной конференции, посвященной 90 -летию со дня рождения академика Г.И. Марчука, Институт вычислительной математики и математической геофизики СО РАН. Новосибирск: Абвей, 2015. С. 321-325.

\section{О КЛАСТЕРИЗАЦИИ ТЕРРИТОРИИ РЕГИОНА ОТНОСИТЕЛЬНО ПОЛИГОНОВ ТКО}

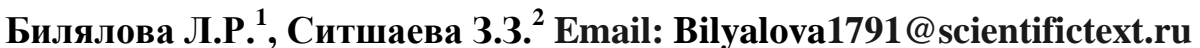

${ }^{\prime}$ Билялова Лилия Ремзиевна - кандидат географических наук, дочент;

${ }^{2}$ Ситиаева Зера Зекерьяевна - кандидат физико-математических наук, доцент, кафедра математики, инженерно-технологический факультет,

Крымский инженерно-педагогический университет, г. Симферополь

\begin{abstract}
Аннотация: в статье рассматривается проблема кластеризации территории региона с учетом мест складирования твердых коммунальных отходов. Обсуждаются особенности, усложняющие прочесс обращения с ними в регионах туристической и рекреачионной профилизации. Отмечается необходимость учета не только экономической эффективности, но и долгосрочной перспективы развития региона. Приводится обзор подходов, используемых для обоснования размещения полигонов твердых коммунальных отходов и маршрутов их перемещения. В работе получена кластеризачия территории Крыма относительно нескольких полигонов с использованием триангуляиии Делоне. Результаты сравниваются с проектныли решениями.
\end{abstract}

Ключевые слова: полигон, твердые коммунальные отходы, кластер. 


\title{
ON CLUSTERING THE REGION IN RELATION TO MSW LANDFILLS Bilyalova L.R. ${ }^{1}$, Sitshaeva Z.Z. ${ }^{2}$
}

\author{
${ }^{I}$ Bilyalova Liliya Remzievna - PhD, assistant-professor; \\ ${ }^{2}$ Sitshaeva Zera Zekeryaevna - PhD, assistant-professor, \\ DEPARTMENT OF MATHEMATICS, FACULTY OF ENGINEERING AND TECHNOLOGY, \\ CRIMEAN ENGINEERING AND PEDAGOGICAL UNIVERSITY, SIMFEROPOL
}

\begin{abstract}
: the paper deals with a problem of a clustering a region's territory in relation to the landfills of municipal solid waste. The features that complicate the process of their treatment in the tourist and recreational regions are discussed. It is noted the necessity of taking into account not only economic efficiency but also long-term development of the region. The review of different approaches and methods that used to justify the landfills of storage facilities and processing of municipal solid waste, as well as the routes of their movement is given. To territory dividing the using of Delaunay triangulation is offered. The obtained results are compared with the existing design solutions.
\end{abstract}

Keywords: landfill, municipal solid waste, cluster.

УДК 504

Актуальной проблемой для человечества и окружающей среды становится не только стремительно увеличивающийся объем производимых отходов, а также их структура и качественный состав: растет доля материалов, разложение которых занимает продолжительное время или оказывается экологически опасным. Вторичной переработке и утилизации могут быть подвергнуты не все компоненты твердых коммунальных отходов (далее - ТКО), поэтому проблема их транспортировки и размещения на оборудованных полигонах является и останется актуальной еще на очень длительный период времени.

Цель данной работы - обсудить применение методов математического моделирования для решения проблемы кластеризации территории региона с учетом расположения полигонов ТКО.

Проблемы складирования и утилизации коммунальных отходов, в том числе и твердых бытовых, особенно остро стоят перед развитыми странами (см., например, анализ причин в [3, c. 54]), и общество уделяет решению этих вопросов серьезное внимание. При этом наибольшую озабоченность вопросы переработки и складирования продуктов жизнедеятельности человека вызывают в регионах рекреационно-туристической направленности. Это связано, с одной стороны, с тем, что выделение площадей под полигоны захоронения ТКО является затруднительным с точки зрения эффективности использования территорий в этих регионах, а также может влиять на подземные воды и минеральные ресурсы, а с другой стороны, продукты переработки ТКО либо выбрасываются в атмосферу, либо опять-таки подлежат захоронению. К тому же, если в регионе рекреационно-туристического профиля есть предприятия химической промышленности, это усугубляет положение дел. Поэтому в настоящее время используются и обсуждаются различные подходы к размещению объектов складирования и переработки ТКО, а также маршрутам их перемещения. Некоторые авторы предлагают использовать следующую логистическую схему: «При определении траектории движения использованных товаров из мест их потребления конечной точкой назначения может быть предприятие, где товар был изготовлен, или другое предприятие этой же отрасли» [3, с. 54-55].

Как известно, основополагающим принципом логистического подхода является экономическая эффективность, которая связана с «определением разницы между результатами деятельности и затратами на достижение этих результатов» [11, с. 56]. Однако, вряд ли следует оценивать результаты деятельности системы по складированию и переработке коммунальных отходов сухим языком тонн переработанных отходов и затрат на переработку или перемещение условной единицы их объема. Ясно, что в данном случае следует учитывать и долгосрочную перспективу, в том числе и влияние на окружающую среду, которую весьма нетривиально описать в формализованном виде. Здесь мы сталкиваемся с проблемой выявления факторов, зачастую различным образом взаимосвязанных и по-разному влияющих на безопасность объекта [1, с. 51]. В работе [1] обсуждается применение для этой цели корреляционнорегрессионного, дискриминантного, факторного, кластерного методов многомерного математико-статистического анализа.

В регионе рекреационно-туристической направленности приоритетными представляются качественные показатели окружающей среды, а также некоторые социальные и демографические факторы. Недаром исследователи подчеркивают нематериальный характер 
понятия «туристический потенциал», подразумевая под ним «сумму объективных или субъективных условий»; в [8, c. 57] для оценки туристической привлекательности территорий предлагается использовать SWOT-анализ.

Заслуживает внимания и стратегическое планирование на основе «пространственновременного подхода», ориентированного «на получение долговременного социальноэкономического эффекта», не ограниченного «частными интересами хозяйствующих субъектов, стремящихся получить прибыль в краткосрочном периоде» [12, с. 41]. В этом случае применение логистического подхода позволяет обеспечить «сбалансированное развитие и укрепление социально-экономического потенциала региона».

Следует просчитывать возможные эколого-экономические риски с учетом экономического потенциала и природоохранной деятельности региона; отмечается необходимость разработки «комплекса логистических моделей концентрации и утилизации газовых, жидких и твердых отходов на территориях сельскохозяйственных и городских муниципальных образований» с применением картографического, системного, типологического, статистического, математического подходов [10, с. 677]. Необходим взвешенный подход к выбору «моделей сбора, перемещения, концентрирования и переработки отходов, а также минимизации геоэкологических рисков воздействия на окружающую среду в сельской местности и малых городах» $[10$, с. 675$]$. Отдельные ученые используют логистический подход для оптимизации размещения полигонов ТКО, учитывают средние значения ТКО, демографические показатели и расходы на транспортировку $[4,5]$. В [6] рассмотрены транспортно-логистические модели, основанные на проблеме Штейнера, р -медианах и др.

В данной работе обсуждается аналогичный подход к расположению полигонов ТКО в Крымском регионе.

В 2017 году утверждена территориальная схема обращения с отходами Республики Крым [7], в которой названы приоритетными сельскохозяйственные, опасные бытовые отходы и ТКО, количество источников последних составляет 28212, а расчетное количество ТКО по республике в целом - 1021 т/год в 2016 году, 1258 т/год - в 2030. Схемой предусмотрено 6 зон деятельности региональных операторов, в каждой из которых с целью сокращения транспортных затрат предполагается двухэтапная схема транспортировки: отходы поступают на мусороперегрузочные станции и мусоросортировочные комплексы, а затем поступают на конечный объект захоронения (т.е. полигон ТКО).

По мнению экологов [2], для захоронения отходов без нарушения экологического состояния прилегающих территорий с применением современных рекультивационных технологий достаточно трех полигонов ТКО: Елизаветовского - для западных районов, Тургеневского для центрального Крыма, Бондаренковского - для Керченского полуострова.

Мы рассматриваем задачу кластеризации территории Крыма, оптимизирующей транспортировку ТКО в следующих предположениях:

А) имеются три рекомендуемых экологами полигона ТКО: Е1 - в районе с. Елизаветово, Е2 - вблизи с. Тургенево, Е3 - около с. Бондаренково; Б) имеются 9 действующих полигонов ТКО: 1 - п.г.т. Черноморское, 2 - с. Перекоп, 3 - с. Тургенево, 4 - Джанкой, 5 - Красногвардейское, 6 - Евпатория, 7 - Советский, 8 - Феодосия, 9 - Ленино (см. [9]).

На основе транспортно-логистического подхода и триангуляции Делоне получено два варианта кластеризации территории крымского региона. Для случая А результирующие кластеры (см. рис. 1) покрывают проектные кластеры, описанные в [7]: западный кластер, полигон в Елизаветово $\rightarrow$ кластер 3 и западная часть кластера 4; центральный кластер, полигон в Тургенево $\rightarrow$ центральная часть кластера 4 , кластеры 1,2 и 5; восточный кластер, полигон в Бондаренково $\rightarrow$ кластер 6 . 


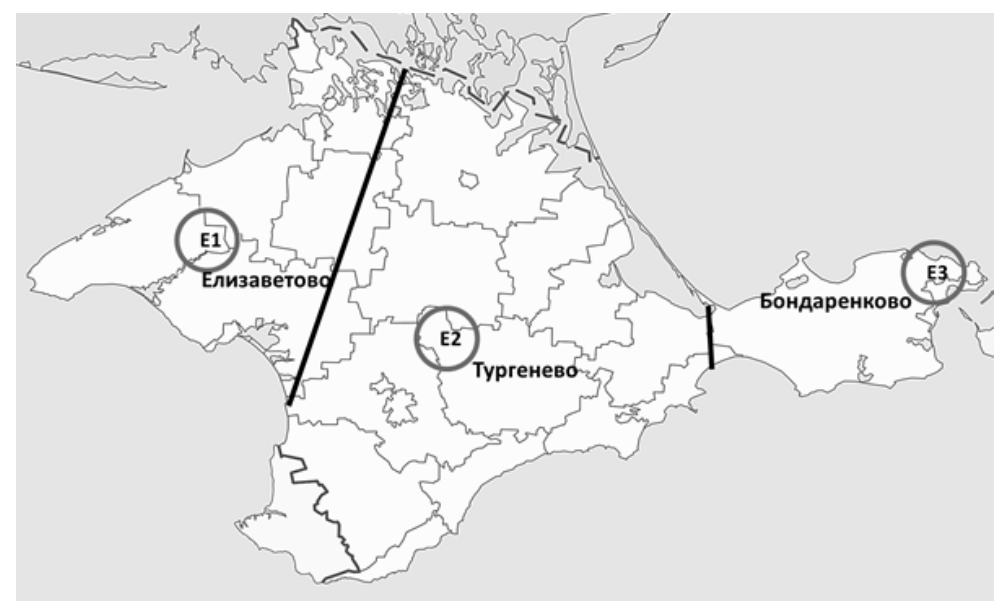

Рис. 1. Расчетные кластеры обслуживания полигонами ТКО

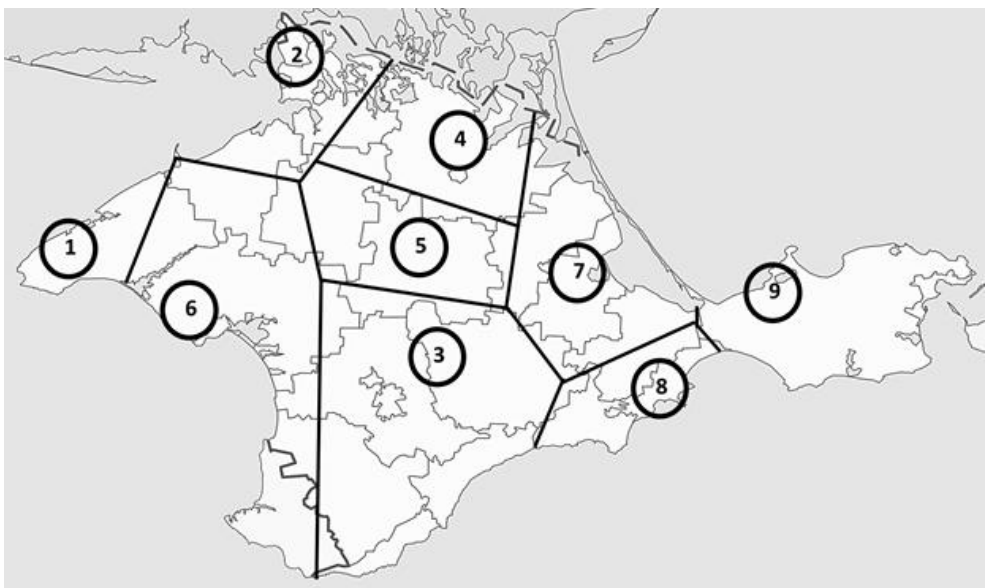

Рис. 2. Расчетные кластеры обслужсивания действующими полигонами ТКО:

1 - п.г.т. Черноморское, 2 - с. Перекоп, 3 -с. Тургенево; полигоны 4 - 9 не лицензированы

Покрытие расчетными кластерами (случай Б) проектных кластеров представлено в таблице 1. Полученные в данной работе результаты адекватно отражают транспортно-логистическую компоненту эффективности обращения с ТКО и могут быть в дальнейшем развиты и уточнены с учетом других факторов.

Таблица 1. Соответствие расчетных и проектных кластеров

\begin{tabular}{|c|c|}
\hline Расчетные кластеры (рис. 2) & Проектные кластеры (по [7]) \\
\hline 1 & Западная часть кластера 3 \\
\hline 2 & Западная часть кластера 4 \\
\hline 3 & Кластеры 1, 2 \\
\hline 4 & Центральная часть кластера 4 \\
\hline 5 & Южная часть кластера 4 \\
\hline 6 & Восточная часть кластера 3 \\
\hline 7 & Кластер 5 \\
\hline 8 & Кластер 6 \\
\hline 9 & \\
\hline
\end{tabular}


1. Большакова Л.В., Яковлева Н.А. Современные математико-статистические методы обработки информации в научной и практической работе // Проблемы современной науки и образования, 2016. № 7 (49). С. 49-52.

2. Для Крыма достаточно всего трёх полигонов ТБО (Крымское информационное агентство). [Электронный ресурс]. Режим доступа: https://kianews24.ru/news/dlya-kryma-dostatochnovsego-treh-poligonov-tbo-ekolog/ (дата обращения: 10.03.2017).

3. Левкин Г.Г. Использование концепции интегрированной логистики для защиты окружающей среды // Проблемы современной науки и образования, 2016. № 30 (72). C. 54-55.

4. Манохин В.Я. Выбор оптимальных вариантов размещения объектов санитарной очистки и технологий переработки отходов (на примере г. Воронежа) // Научный вестник Воронежского ГАСУ. Строительство и архитектура, 2011. Вып. 4 (24). С. 150-159.

5. Манохин М.B, Скляров К.А. Разработка математической модели транспортирования отходов // Научный вестник Воронежского ГАСУ. Строительство и архитектура, 2015. № 2 (38). C. $103-110$.

6. Петухов В.В., Кулибаба $B . B$. Региональная информационно-аналитическая система мониторинга оборота твердых бытовых отходов // Труды СПИИРАН, 2013. № 2 (25). C. $338-349$.

7. Постановление Совета министров Республики Крым № 1 от 12.01.2017 «Об утверждении территориальной схемы обращения с отходами, в том числе с твердыми коммунальными отходами, Республики Крым». [Электронный ресурс]. Режим доступа: http://mzhkh.rk.gov.ru/rus/file/pub/pub_323868.pdf./ (дата обращения: 10.03.2017).

8. Султанль С.И. Применение SWOT-анализа при исследовании территории // Проблемы современной науки и образования, 2016. № 10 (52). С. 57-59.

9. Схема обращения с отходами на территории Республики Крым // Крымская газета. [Электронный ресурс]. Режим доступа: https://gazetacrimea.ru/news/print/shema-obrasheniyas-othodami-na-territorii-respybliki-krim-20673/ (дата обращения: 10.03.2017).

10. Чернятина Г.Н., Межова Л.А., Луговской А.М. Экономическая оценка эффективности и экологический мониторинг технологической схемы рекультивации объектов размещения бытовых отходов на территории муниципальных районов // Фундаментальные исследования, 2015. № 5. С. 675-678.

11. Шамис В.А. Некоторые аспекты эффективности логистических процессов // Проблемы современной науки и образования, 2017. № 3 (85). С. 54-56.

12. Якубов М.С., Кубаев У.Р. Стратегии развития логистического инновационного потенциала региона // Проблемы современной науки и образования, 2016. № 5 (47). С. 41-43. 


\title{
МЕТОД ОПРЕДЕЛЕНИЯ ХАРАКТЕРИСТИК УПРУГОСТИ ТВЕРДЫХ МАТЕРИАЛОВ \\ Тажибаев К.Т. ${ }^{1}$, Ормонов М.Ж. ${ }^{2}$ Email: Tazhibayev1791@scientifictext.ru \\ ${ }^{I}$ Тажибаев Кушбакали Тажибаевич - доктор технических наук, профессор, заведуюший лабораторией; \\ ${ }^{2}$ Ормонов Манас Жайлообаевич - аспирант, лаборатория «Механика горных пород», \\ Институт геомеханики и освоения недр Нацииональной академии наук Кыргызской Республики, 2. Биикек, Кыргызская Республика
}

\begin{abstract}
Аннотация: показано, что значения характеристик упругости горных пород, полученные при статическом и динамическом способах (ультразвук) измерений, существенно отличаются между собой, и нет четко определенной тендениии в сторону увеличения или уменьшения значений характеристик упругости динамического способа по сравнению $c$ соответствующими данными статического. Установлено, что значительное и бессистемное расхождение результатов указанных методов обусловлено ограниченностью области применения известных формул динамического метода и неточным определением коэффициента Пуассона. Предложена формула для определения коэффициента Пуассона по скоростям распространения продольной и поперечной ультразвуковой волны и на этой основе разработан метод определения характеристик упругости твердых материалов. Представлены результаты определения характеристик упругости горных пород $u$ технических материалов предложенным методом.
\end{abstract}

Ключевые слова: упругость, горная порода, ультразвук, характеристики упругости, напряжения, ультразвуковая волна.

\section{METHOD FOR DETERMINATION OF SOLID MATERIALS ELASTICITY CHARACTERISTICS Tazhibayev K.T. ${ }^{1}$, Ormonov M.J. ${ }^{2}$}

\author{
${ }^{I}$ Tazhibaev Kushbakali Tazhibaevich - Doctor of Technical Sciences, Professor, \\ HEAD OF LABORATORY; \\ ${ }^{2}$ Ormonov Manas Zhayloobaevich - graduate student, \\ LABORATORY "ROCK MECHANICS", \\ INSTITUTE OF GEOMECHANICS AND DEVELOPMENT OF EARTH BOWELS OF THE NATIONAL \\ ACADEMY OF SCIENCES OF KYRGYZ REPUBLIC, BISHKEK, REPUBLIC OF KYRGYZSTAN
}

\begin{abstract}
: it is shown that the values of the elasticity characteristics of rocks obtained at static and dynamic measurements methods (ultrasound) differ between themselves significantly, and there is no clearly defined tendency to the direction of increase or decrease the values of the elastic characteristics of the dynamic method on comparison with appropriate data of static method. It is established that a significant and unsystematic results discrepancy of specified methods caused by limitation of using area of the dynamic method known formulas and inaccurate determination of Poisson's ratio. It is proposed formula for Poisson's ratio determination on the velocities of longitudinal and transverse ultrasonic waves propagation and on this basis it is developed a method for determination of solid materials elasticity characteristics. The results of elasticity characteristics determination of rocks and technical material by proposed method are presented.
\end{abstract}

Keywords: elasticity, rock, ultrasound, elasticity characteristics, stresses, ultrasonic wave.

УДК 534.8.081.7, 539.32

Известно, что скорость распространения упругих волн в значительной мере зависит от характеристик упругости и плотности материала. Поэтому в настоящее время для определения характеристик упругости, а именно модулей упругости, сдвига, объемной упругости и коэффициента Пуассона твердых материалов, в том числе природных горных пород, получил широкое применение метод определения скоростей распространения продольных и поперечных (сдвиговых) упругих волн - ультразвуковой динамический метод. Этот метод в настоящее время является одним из наиболее перспективных, так как он значительно дешевле и проще 
других известных (особенно статических) методов. Кроме того, метод позволяет определять свойства горных пород в массиве, их анизотропность, что делает его незаменимым при проведении горных работ в натурных условиях: определении параметров буровзрывных работ, устойчивости обнажений горных выработок и т.д.

В соответствии с теорией упругости скорость распространения продольной $V_{p}$ и поперечной $V_{s}$ упругой волны в массиве горных пород определяются по следующим формулам [2].

$$
V_{p}=\sqrt{\frac{E g(1-\mu)}{\gamma(1+\mu)(1-2 \mu)}} \quad(1), \quad V_{s}=\sqrt{\frac{G g}{\gamma}}=\sqrt{\frac{E g}{\gamma 2(1+\mu)}}
$$

где Е - модуль упругости (Юнга), $g$ - ускорение свободного падения,

$\gamma$ - объемный вес, $\mu$ - коэффициент Пуассона, $G$ - модуль сдвига.

Из формулы 1: $E=\frac{V_{p}^{2} \gamma(1+\mu)(1-2 \mu)}{g(1-\mu)}$

Из формулы 2: $G=\frac{E}{2(1+\mu)}$

Для определения модуля объемной упругости $\boldsymbol{B}$ применяется следующая формула [3]:

$$
\mathrm{B}=\frac{E}{3(1-2 \mu)}
$$

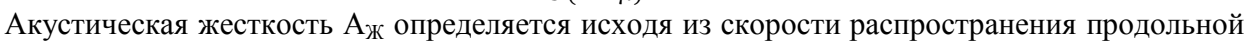
упругой волны $\mathrm{A}_{ж}=\rho \cdot V_{\mathrm{P}}(6)$,

где $\rho$ - плотность горной породы (материала).

Л. Бергманом показано, что по соотношению скоростей распространения продольной и поперечной упругой волны можно определить коэффициент Пуассона [3]. Например, из соотношения $\frac{V_{p}}{V_{s}}=\sqrt{\frac{2(1-\mu)}{1-2 \mu}}$ получено

$$
\mu=\frac{2-\left(V_{p} / V_{s}\right)^{2}}{2-2\left(V_{p} / V_{s}\right)^{2}}
$$

Позже широкое распространение и применение получила следующая формула [1]:

где $R=\frac{V_{S}}{V_{\mathrm{P}}}$

$$
\mu=\frac{0,5-(R)^{2}}{1-(R)^{2}}
$$

Следует отметить, что формулы 7 и 8 тождественны.

Ржевский В.В., Новик Г.Я. отмечают [2], что скорости распространения упругих волн в горных породах определяются их свойствами упругости и плотностью, при этом скорости практически не зависят от частоты колебаний волн. Соотношение $V_{p} / V_{s}$ является функцией коэффициента Пуассона и это соотношение (формула 7) для изверженных и метаморфических горных пород изменяется в пределах от 1,7 до 1,9. Более значительны его колебания в осадочных горных породах - от 1,5 до 14. Из-за низкого сопротивления сдвигу оно очень велико для глинистых горных пород, а в рыхлых горных породах стремиться к бесконечности. Таким образом, авторы отмечают ограниченность соотношений 7 и 8 для практического применения.

Практика и наш анализ показывает, что формулы 7 и 8 действительно ограничены для широкого применения для разных твердых материалов. Например, при значениях $V_{P}=5000 \mathrm{M} / \mathrm{c}$, $V_{S}=3550 \mathrm{~m} / \mathrm{c}$ по формулам 7 и $8 \mu=0,0083$, что не соответствует действительности из-за нереального расчетного результата, а в неоднородных горных породах и материалах указанные выше значения скорости встречаются часто. Для горной породы со значением $\frac{V_{p}}{V_{s}}=14$ [2] по формулам 7 и 8 коэффициент Пуассона, т.е. $\mu=0,497$, что также не соответствует действительности по данным статических измерений. При значениях $R^{2}=0,5$ или при $\left(V_{p} /\right.$ $\left.V_{s}\right)^{2}=2$ по формуле 7 и 8 коэффициент Пуассона, то есть $\mu=0$, что также не реально, а горные породы с указанными выше значениями отношения квадрата скоростей распространения продольной и поперечной упругой волны встречаются достаточно часто.

Значения характеристик упругости горных пород, полученные при статическом (по испытаниям статического сжатия) и динамическом (ультразвук) воздействии (по формулам $3,4,5,6,7,8)$ сильно отличаются между собой, причем нет четко определенной тенденции в сторону увеличения или уменьшения значений характеристик упругости динамического метода по сравнению с соответствующими данными статического метода (табл.1). 

методу) [1]

\begin{tabular}{|c|c|c|c|c|c|c|c|c|c|}
\hline \multirow[b]{2}{*}{ Порода } & \multicolumn{2}{|c|}{$\begin{array}{c}\text { Модуль } \\
\text { упругости, } \\
\mathbf{E} \cdot 10^{5}, \\
\text { КГ/см' } \\
\end{array}$} & \multicolumn{2}{|c|}{$\begin{array}{c}\text { Коэффи- } \\
\text { циент } \\
\text { Пуассона }\end{array}$} & \multicolumn{2}{|c|}{$\begin{array}{c}\text { Модуль } \\
\text { сдвига, } \\
\text { С·10 } \\
\text { кГ/см' }\end{array}$} & \multicolumn{2}{|c|}{ 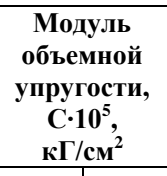 } & \multirow[b]{2}{*}{$\begin{array}{l}\mathbf{E}_{2} / \\
\mathbf{E}_{\text {ст }}\end{array}$} \\
\hline & 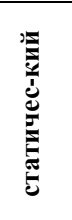 & 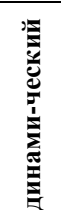 & 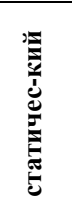 & 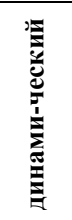 & 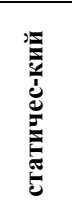 & 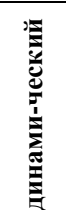 & 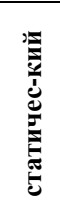 & 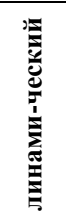 & \\
\hline 1 & 2 & 3 & 4 & 5 & 6 & 7 & 8 & 8 & 10 \\
\hline $\begin{array}{c}\text { Известняк } \\
\text { мраморизиров. }\end{array}$ & 7,1 & 6,0 & 0,42 & 0,22 & 2,50 & 2,22 & 14,8 & 3,6 & 0,84 \\
\hline Гранит-порфирит & 6,6 & 6,4 & 0,38 & 0,26 & 2,40 & 2,40 & 9,2 & 4,4 & 0,97 \\
\hline $\begin{array}{c}\text { Магнетит } \\
\text { мелкозернистый } \\
\end{array}$ & 8,2 & 17,2 & 0,34 & 0,33 & 3,1 & 4,40 & 8,6 & 17,3 & 2,10 \\
\hline Песчаник кварцевый & 4,5 & 8,6 & 0,21 & 0,42 & 1,85 & 1,28 & 2,6 & 13,6 & 1,90 \\
\hline $\begin{array}{c}\text { Руда железная } \\
\text { окисленная }\end{array}$ & 5,2 & 5,1 & 0,18 & 0,35 & 2,20 & 1,10 & 2,7 & 5,6 & 0,97 \\
\hline Известняк & 2,25 & 5,6 & 0,29 & 0,27 & 1,8 & 2,20 & 1,8 & 4,09 & 2,50 \\
\hline Гранит & 2,90 & 5,6 & 0,07 & 0,13 & 2,80 & 2,51 & 1,1 & 2,61 & 1,95 \\
\hline Оруденелый скарн & 8,7 & 8,1 & 0,26 & 0,32 & 3,45 & 2,14 & 6,0 & 7,5 & 0,93 \\
\hline
\end{tabular}

Как видно из таблицы, статические методы, в отдельных случаях, дают завышенные значения, а в других - заниженные, то есть, нет определенной тенденции в сторону увеличения или уменьшения динамических характеристик упругости по сравнению с данными статического метода.

Сопоставляя статических и динамических характеристик упругости горных пород Е.С. Ватолин [8] отмечает, что динамический модуль упругости в большинстве случаев выше статического нагружения.

Другие исследователи [1] отмечают, что при статическом методе определения модуля упругости время нагружения исчисляется минутами, вследствие чего наблюдаются сравнительно большие пластические деформации, которые снижают значение модуля упругости. При динамических же испытаниях, нагрузки, прилагаемые на образец материала, кратковременны и не большие по величине, поэтому пластических деформаций здесь практически нет, то есть не успевают развиваться пластические деформации.

Однако следует отметить, что во многих случаях, наоборот статический модуль упругости превышает динамический модуль упругости (см. табл. 1) и в первом и во втором случае рассматриваются деформационные процессы в пределах упругости, и при статическом сжатии в пределах упругости деформации распространяются с такой же скоростью, как при динамическом воздействии. Поскольку определяются характеристики упругости, пластические деформации в данных случаях не должны рассматриваться.

Значительное и бессистемное расхождение результатов определения характеристик упругости твердых материалов динамическим методом, по сравнению с данными статического метода, как нами показано выше, связано с ограниченностью области применения известных формул 7 и 8 динамического метода и неточным определением коэффициента Пуассона. И далее, как следствие, будут иметь место значительные расхождения результатов определения соответственно и других динамических характеристик упругости по формулам 3,4 и 5 от данных статического метода, так как в эти формулы входит коэффициент Пуассона. Поэтому в первую очередь необходимо более точно определить величину коэффициента Пуассона, 
представляющего собой отношение относительной поперечной деформации к относительной продольной деформации при статическом продольном сжатии.

Согласно структурной модели квазиизотропной горной породы [4] при статическом сжатии каждый структурный элемент (зерно, кристаллическая отдельность и т.д.) на свободной боковой поверхности, через которое осуществляется поперечная деформация, от сжимающего структурного элемента в вертикальной плоскости, получает $1 / 2$ часть приложенной продольной силы - напряжения.

Напряжения, как векторные величины вызывают соответствующие деформации по соответствующим направлениям, а скорости распространения продольной и поперечной (сдвиговой) упругой волны зависят от структуры и напряженно-деформированного состояния по соответствующим направлениям.

В среднем для горных пород и других технических материалов [3]: $\frac{V_{s}}{V_{p}}=0,5$.

Исходя из этого и вышеизложенного, представим, что

$$
\frac{\sigma_{x}}{\sigma_{z}}=\frac{V_{s}}{2 V_{p}}
$$

где $\sigma_{z}$ и $\sigma_{x}$ - вертикальное (продольное) сжимающее и горизонтальное (поперечное) растягивающее нормальное напряжение соответственно.

По Диннику А.Н. [5] вертикальное и горизонтальное нормальное напряжение определяется по следующим формулам:

$\sigma_{z}=\gamma H$

где $m$ - боковой распор, $m=\frac{\mu}{1-\mu}$;

$$
\sigma_{x}=\sigma_{y}=m \sigma_{z} \quad(10),
$$

$\gamma$ - объемный вес горной породы;

$H$ - глубина залегания горной породы.

Подставляя в формулу 9 значение $\sigma_{x}=m \sigma_{z}$ из формулы 10 , получим:

$m=\frac{V_{s}}{2 V_{p}}$ или

$$
\frac{\mu}{1-\mu}=\frac{V_{s}}{2 V_{p}}
$$

решая уравнение 11 относительно $\mu$, получим:

$$
\mu=\frac{V_{s}}{2 V_{p}+V_{s}}
$$

В расчетах рекомендуем сначала определить $\mu$ по формуле 12 , а затем определять другие характеристики упругости по формулам $3,4,5$.

Считается, что первое вступление волн на осциллограмме характерно для прихода продольной волны, а колебания большей амплитуды отмечают приход поперечной волны, однако данный метод не позволяет точно определить скорость распространения поперечной волны, так как ее приход очень трудно выделить из серии отраженных и преломленных волн. Поэтому нами для измерения скорости прохождения поперечной волны применялся специально разработанные Ф.Ф. Горбацевичем [7] (Геологический институт Кольского научного центра РАН) излучатели и приемники поперечных волн. При измерениях ультразвуковых волн применялся прибор типа УК -10ПМ.

В таблице 2 представлены результаты определения характеристик упругости твердых материалов разными, в том числе предложенным методом. 
Таблица 2. Характеристики физико-механических свойств горных пород [6] и некоторых металлов [3]

\begin{tabular}{|c|c|c|c|c|c|}
\hline $\begin{array}{c}\text { Название } \\
\text { горной породы }\end{array}$ & $\begin{array}{c}\text { Объемный } \\
\text { вес, } \mathbf{T} / \mathbf{M}^{3}\end{array}$ & $\begin{array}{c}\text { Модуль } \\
\text { упругости, } \\
10^{5}, \text { кГ/см' } \\
\text { (стат. метод, } \\
\text { тензом.) }\end{array}$ & $\begin{array}{c}\text { Коэфф-т } \\
\text { Пуассона } \\
\text { (статич. } \\
\text { метод, } \\
\text { тензом.) }\end{array}$ & $\begin{array}{l}\text { Скорость } \\
\text { продоль-ной } \\
\text { волны, м/с }\end{array}$ & $\begin{array}{c}\text { Скорость } \\
\text { попереч-ной } \\
\text { волны, м/с }\end{array}$ \\
\hline 1 & 2 & 3 & 4 & 5 & 6 \\
\hline \multicolumn{6}{|c|}{ Хайдаркенское месторождение, рудник Хайдаркен, карьер Кара - Арга } \\
\hline Арагонит & 2,74 & $\begin{array}{c}3,1 / 5,14 \\
(6,02)\end{array}$ & $\begin{array}{c}0,26 / 0,25 \\
(0,105)\end{array}$ & 4700 & 3120 \\
\hline $\begin{array}{c}\text { Брекчия } \\
\text { известково- } \\
\text { кварцитовая }\end{array}$ & 2,78 & $\begin{array}{c}4,8 / 6,48 \\
(4,5)\end{array}$ & $\begin{array}{c}0,27 / 0,2 \\
(0,35)\end{array}$ & 5040 & 2440 \\
\hline $\begin{array}{c}\text { Брекчия } \\
\text { роговиково- } \\
\text { кварцевая }\end{array}$ & 2,82 & $\begin{array}{c}6,1 / 5,3 \\
(4,4)\end{array}$ & $\begin{array}{l}0,21 / 0,23 \\
\quad(0,19)\end{array}$ & 5130 & 3160 \\
\hline $\begin{array}{l}\text { Брекчия } \\
\text { роговиково- } \\
\text { кварцевая с } \\
\text { антимонит. }\end{array}$ & 2,98 & $\begin{array}{c}5,1 / 4,6 \\
(4,6)\end{array}$ & $\begin{array}{l}0,38 / 0,23 \\
(0,23)\end{array}$ & 4170 & 2470 \\
\hline $\begin{array}{l}\text { Известняки } \\
\text { окремнен. } \\
\text { трещинов. }\end{array}$ & 2,84 & $\begin{array}{c}6,1 / 7,5 \\
(6,9)\end{array}$ & $\begin{array}{l}0,13 / 0,22 \\
(0,27)\end{array}$ & 5450 & 3040 \\
\hline $\begin{array}{l}\text { Песчаники } \\
\text { серые }\end{array}$ & 2,9 & $\begin{array}{c}4,8 / 5,0 \\
(5,5)\end{array}$ & $\begin{array}{c}0,21 / 0,25 \\
(0,07)\end{array}$ & 4500 & 3060 \\
\hline \multicolumn{6}{|c|}{$\begin{array}{c}\text { Примечание: 1- в числителе данные по методу проволочных датчиков[6]; } \\
\text { 2- в знаменателе данные по формуле } 12 \text { (ультразвук); } \\
\text { 3- в скобке данные по формулам } 3 \text { и } 8 \text { (ультразвук). }\end{array}$} \\
\hline \multicolumn{6}{|c|}{ Эстонсланец, карьер Вийвиконд } \\
\hline Известняк & 2,38 & $\begin{array}{c}2,50 / 2,43 \\
(3,0)\end{array}$ & $\begin{array}{c}0,13 / 0,26 \\
(0,0039) \\
\end{array}$ & 3500 & 2470 \\
\hline $\begin{array}{c}\text { Известняк } \\
\text { A-B }\end{array}$ & 2,30 & $\begin{array}{c}2,20 / 2,05 \\
(2,51) \\
\end{array}$ & $\begin{array}{c}0,09 / 0,26 \\
(0,002)\end{array}$ & 3270 & 2310 \\
\hline $\begin{array}{c}\text { Известняк } \\
\text { С-В }\end{array}$ & 1,84 & $\begin{array}{c}2,70 / 1,8 \\
(2,0)\end{array}$ & $\begin{array}{c}0,12 / 0,27 \\
(0,16)\end{array}$ & 3420 & 2580 \\
\hline 1 & 2 & 3 & 4 & 5 & 6 \\
\hline $\begin{array}{l}\text { Известняк } \\
\text { Е-С } \\
\end{array}$ & 2,14 & $\begin{array}{c}1,40 / 2,14 \\
(1,46) \\
\end{array}$ & $\begin{array}{c}0,37 / 0,19 \\
(0,35) \\
\end{array}$ & 3280 & 1570 \\
\hline Сланец В & 1,50 & $\begin{array}{c}0,76 / 0,72 \\
(0,46)\end{array}$ & $\begin{array}{l}0,13 / 0,28 \\
(0,18)\end{array}$ & 2070 & 1570 \\
\hline \multicolumn{6}{|c|}{$\begin{array}{c}\text { Примечание: 1- в числителе данные по кадастру свойств [6]; } \\
\text { 2- в знаменателе данные по формуле } 12 \text { (ультразвук); } \\
\text { 3- в скобке данные по формулам } 3 \text { и } 8 \text { (ультразвук). }\end{array}$} \\
\hline \multicolumn{6}{|c|}{ Металлы } \\
\hline Железо & 7,8 & $21 / 23,8$ & $0,28 / 0,22$ & 5850 & 3230 \\
\hline Алюминий & 2,7 & $7,1 / 9,7$ & $0,34 / 0,20$ & 6260 & 3080 \\
\hline Золото & 19,3 & $8,12 / 19,39$ & $0,42 / 0,16$ & 3240 & 1200 \\
\hline Серебро & 10,5 & $7,5 / 12,8$ & $0,38 / 0,18$ & 3600 & 1590 \\
\hline Свинец & 11,4 & $1,6 / 5,17$ & $0,44 / 0,14$ & 2160 & 700 \\
\hline Примечание: 1 & $\begin{array}{r}\text { числителе дан } \\
\text { 2- в знам }\end{array}$ & $\begin{array}{r}\text { по динамичес } \\
8)[3 \\
\text { еле данные по }\end{array}$ & $\begin{array}{l}\text { ультразвук } \\
\text { муле } 12 \text { (уль }\end{array}$ & $\begin{array}{l}\text { му методу(по } \\
\text { звук). }\end{array}$ & рмулам 3 и \\
\hline
\end{tabular}


1. Ильниикая Е.И., Тедер Р.И., Ватолин Е.С., Кунтыши М.Ф. Свойства горных пород и методы их определения. М.: Недра, 1969. 392 с.

2. Ржевский В.В., Новик Г.Я. Основы физики горных пород. Учебник для вузов. М.: Недра, 1973. $286 \mathrm{c}$

3. Бергман Л. Ультразвук и его применение в науке и технике. Перевод с немецкого. Под редакцией В.С. Григорьева и Л.Д. Розенберга. М.: Издательство иностранной литературы, 1957. $726 \mathrm{c}$

4. Тажсибаев К.T. Напряжения, процессы деформации и динамического разрушения горных пород. В двух томах. Т. 1. Бишкек: Издательство «Алтын Принт», 2016. 352 с.

5. Динник А.Н. О давлении горных пород и расчет крепи круглой шахты // Инженер, работник, 1925. C. 1-12.

6. Справочник (кадастр) физических свойств горных пород. Под ред. Н.В. Мельникова, В.В. Ржевского, М.М. Протодьяконова. М.: «Недра», 1975. 279 с.

7. Горбацевич Ф.Ф. Акустополярископия породообразующих минералов и кристаллических пород. Апатиты: Изд. Кольского научного центра РАН, 2002. 140 с.

8. Ватолин E.C. Некоторые динамические свойства и природа деформирования горных пород. М.: Наука, 1966. 63 с.

\title{
ФАКТОРЫ, ПОБУЖДАЮЩИЕ СТРАНЫ К СТРОИТЕЛЬСТВУ АТОМНЫХ ЭЛЕКТРОСТАНЦИЙ Акимова К.B. Email: Akimova1791@scientifictext.ru
}

\author{
Акимова Кристина Владимировна - студент, \\ факультет бизнес-информатики и управления комплексньми системами, \\ Национальный исследовательский ядерный университет \\ Московский инженерно-физический институт, г. Москва
}

\begin{abstract}
Аннотация: в настоящее время перед странами мира стоит вопрос о выборе способа генерации электроэнергии. В данной статье рассматриваются аспекты, влияющие на рост строительства атомных электростанций в мире. Глобальный рост населения в сочетании с промышиленным развитием приведет к увеличению потребления электроэнергии, что является одним из главных драйверов энергопотребления. Государства сосредотачивают внимание на последствиях изменения климата в результате сжигания ископаемого топлива. И многие страны начинают задумываться о строительстве атомных электростанций на своих территориях.
\end{abstract}

Ключевые слова: ядерная энергетика, атомные электростанции, электричество, потребление топлива, уран.

\section{THE FACTORS THAT MOTIVATE COUNTRIES TO BUILD NUCLEAR POWER PLANTS Akimova K.V.}

\author{
Akimova Kristina Vladimirovna - student, \\ FACULTY FOR BUSINESS INFORMATICS AND INTEGRATED SYSTEM, \\ NATIONAL RESEARCH NUCLEAR UNIVERSITY MOSCOW ENGINEERING PHYSICS INSTITUTE, MOSCOW
}

\begin{abstract}
: now the countries of the world are faced by a question of the choice of a way of generation of the electric power. The article considers the factors which impact on the growth of construction nuclear plants in the world. Global population growth in combination with industrial development will lead to increased consumption of electricity, which is one of the main drivers of energy consumption. Countries are focusing on climate change caused by burning fossil fuels. And a lot of them are beginning to think about construction of nuclear power plants on their territories.
\end{abstract}

Keywords: nuclear energy, nuclear plant, electricity, fuel consumption, uranium. 
Глобальный рост населения в сочетании с промышленным развитием даст новый толчок в росте потребления электроэнергии. По результатам ООН в середине 2015 года, численность населения достигла 7,3 млрд (таблица 1) [1].

Таблица 1. Прогноз роста населения ООН

\begin{tabular}{|c|c|c|c|c|}
\hline & \multicolumn{4}{|c|}{ Население (млн) } \\
\hline & 2015 & 2030 & 2050 & 2100 \\
\hline Африка & 1186 & 1679 & 2478 & 4387 \\
\hline Азия & 4393 & 4923 & 5267 & 4889 \\
\hline Европа & 738 & 734 & 707 & 646 \\
\hline Латинская Америка и Карибские о-ва & 634 & 721 & 784 & 721 \\
\hline Северная Америка & 358 & 396 & 433 & 500 \\
\hline Океания & 39 & 47 & 57 & 71 \\
\hline Весь мир & 7349 & 8501 & 9725 & 11213 \\
\hline
\end{tabular}

Как показывает статистика, после быстрого роста численности населения начинается этап роста энергопотребления, который является опережающим. Растет индустриализация экономики и увеличивается ВВП на душу населения, который в свою очередь опережает энергопотребение. Обосновать это можно увеличением энергоемкого производства. Поэтому можно утверждать, что динамика электропотребления в развитых и развивающихся странах будет существенно разниться. Развитые страны уже прошли пик энергопотребления, в то время как в развивающихся странах потребление будет расти, базируясь на росте благосостояния населения.

Но для некоторых стран энергетическая бедность останется существенной проблемой, так как увеличение населения будет существенно опережать рост душевого энергопотребления.

Главной темой многих политических программ является обеспечение безопасности поставок, поскольку страны понимают, насколько они уязвимы к перебоям поставок нефти и газа. Доли потребления разных источников различаются (рисунок 1). Обилие естественного урана делает атомные электростанции привлекательными с точки зрения энергетической безопасности. Например, во время нефтяного кризиса начала 1970-х годов Франция была сильно зависима от зарубежных поставок. С тех пор были построены 60 атомных реакторов. В настоящее время атомная энергетика обеспечивает $78 \%$ электроэнергии, она стала крупным экспортером электроэнергии (60 млрд кВт·ч в год) и имеет высокий уровень энергетической независимости [2].

\section{Потребление топлива по регионам мира, МТНЭ}

Северная Америка
ॠжная и Центральная
Америка
Евразия
— Средний Восток
« Африка
$\approx$ Азиатско - Тихоокеанский
регион

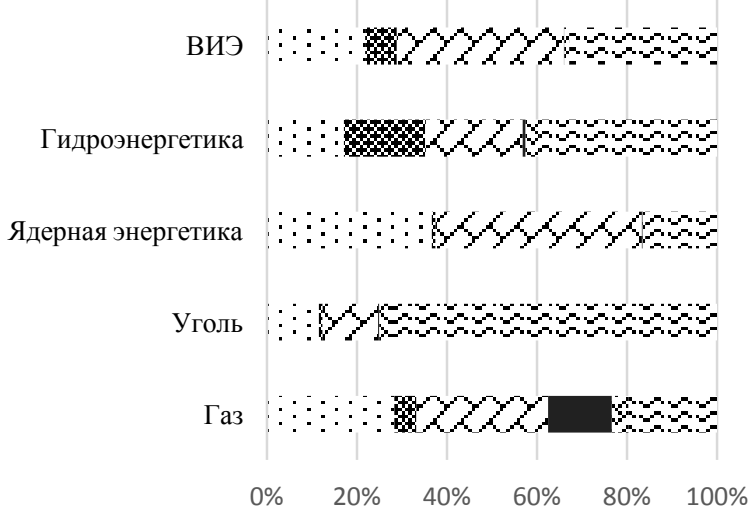

Рис. 1. Потребление топлива по регионам мира, МТНЭ

В последние годы внимание было сосредоточено на последствиях изменения климата в результате сжигания ископаемого топлива, особенно угля, из-за углекислого газа, который при этом выделяется в атмосферу. Выделяемый углекислый газ способствует усилению парникового эффекта. Производство электроэнергии является одним из основных 
источников углекислого газа, порождая 9,5 млрд тонн в год, или примерно четверть антропогенных выбросов.

Страны все более и более обеспокоены устойчивым во всем мире наращиванием уровня $\mathrm{CO}_{2}$ в атмосфере (см. рис. 2), и политические инициативы отражают эту тревогу. Прогрессивная вырубка лесов также вносит свой вклад в парниковый эффект, уменьшая уровень удаления $\mathrm{CO}_{2}$ в процессе фотосинтеза. В настоящее время выбросы $\mathrm{CO}_{2}$ являются значимым фактором при сравнении ядерной и других видов энергетики.

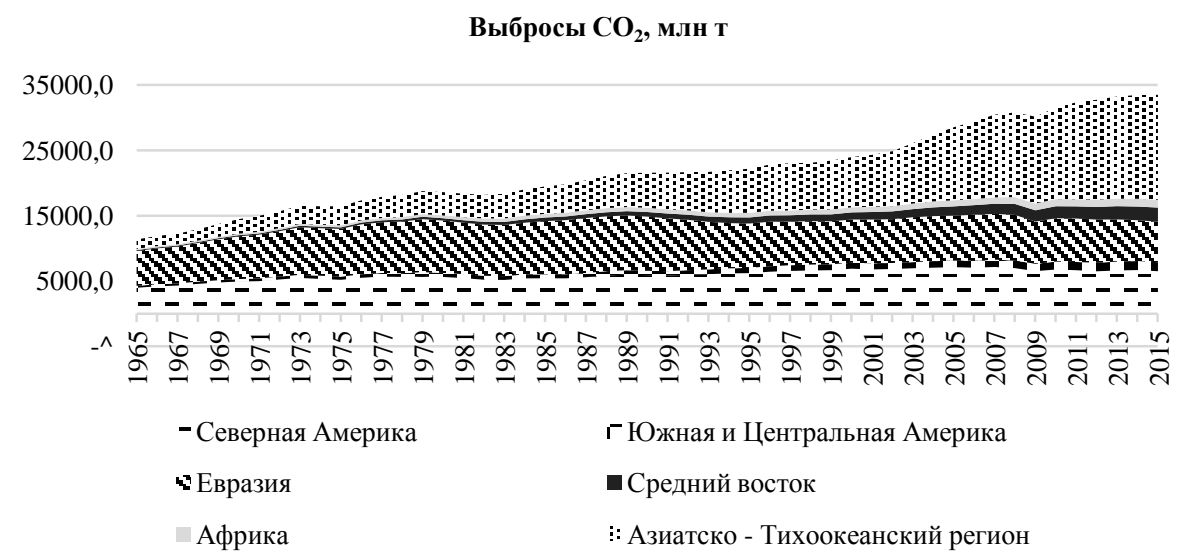

Рис. 2. Выбросы $\mathrm{CO}_{2}$, млн $m$

Во всем мире выбросы СО2 от сжигания ископаемого топлива составляют 34 млрд тонн в год. Около $38 \%$ от угля и $43 \%$ от нефти. Каждые 1000 МВт электростанции, работающей на черном угле, производят около 7 млн тонн в год выбросов СО2. Если используется бурый уголь, то 9 млн тонн. Каждые 22 тонны урана позволяют не попасть в атмосферу 1 млн тонн CO2 по сравнению с углем. Новые технологии помогают уменьшать выбросы (см. рис. 3).

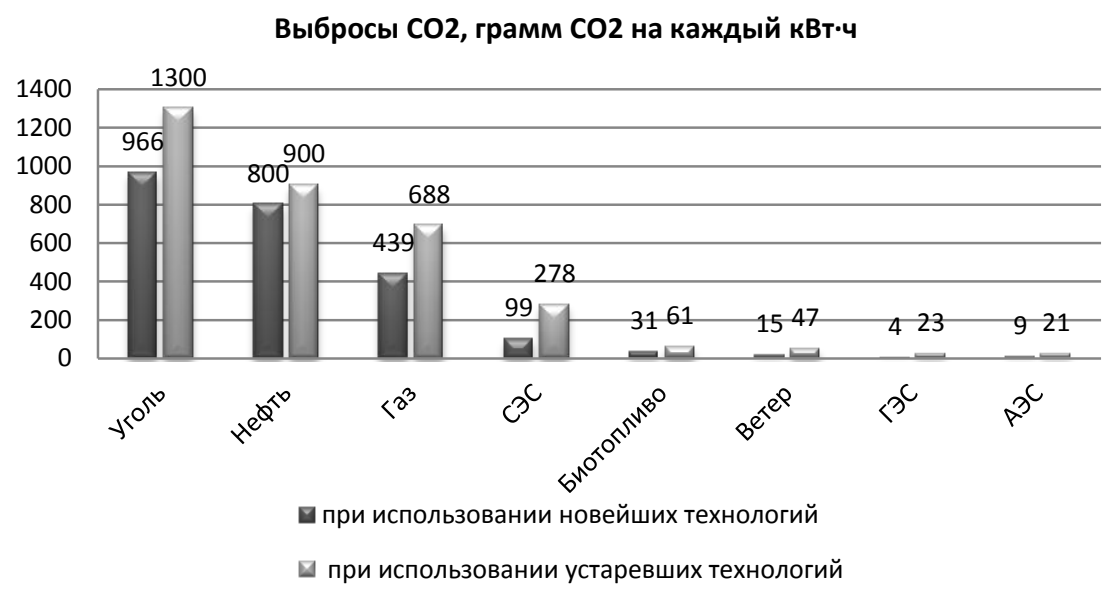

Pис. 3. Выбросы $\mathrm{CO}_{2}$, грамм на кBm·ч

Расходы на топливо с самого начала дали атомной энергетике преимущество перед угольной, нефтяной и газовой энергией. Однако, около половины стоимости происходит за счет обогащения и изготовления. На таблице 2 показана стоимость на 1 кг UO2 реакторного топлива, рассчитанная на июль 2015 года. 
Таблица 2. Составляющче стоимости урана [3]

\begin{tabular}{|c|c|c|c|}
\hline Закупка урана & 8,9 кг U3O8 x \$97 & US\$ 862 & $46 \%$ \\
\hline Конверсия & 7,5 кг U x \$16 & US\$ 120 & $6 \%$ \\
\hline Изотопное обогащение & 7,3 EPP x \$82 & US\$ 599 & $32 \%$ \\
\hline Изготовление ТВC & за кг & US\$ 300 & $16 \%$ \\
\hline Итого & & US\$ 1880 & \\
\hline
\end{tabular}

Но даже с этим общая стоимость топлива АЭС в странах ОСЭР, как правило, равна трети стоимости топлива угольной электростанции и примерно одной четвертой стоимости топлива газовой электростанции комбинированного цикла. Около $78 \%$ расходов на угольных электростанциях идут на топливо, а на газовых электростанциях этот показатель достигает $89 \%$. В то время как на АЭС $14 \%$ расходов идут на топливо [3].

Уран имеет преимущество высококонцентрированного источника энергии, который легко транспортируется. Урана требуется намного меньше, чем угля. Один килограмм природного урана будет приносить примерно в 20000 раз больше энергии, чем такое же количество угля. Поэтому уран можно считать очень компактным ресурсом. Вклад топлива в общую стоимость произведенной электроэнергии сравнительно невелик, поэтому даже большой рост цен на топливо будет иметь сравнительно незначительный эффект.

\section{Список литературы / References}

1. ООН. [Электронный pecypc] / World Population Prospects. Офиц. сайт Режим доступа: https://esa.un.org/unpd/wpp/Publications/Files/Key_Findings_WPP_2015.pdf/ (дата обращения: 12.12.2016).

2. World Nuclear Association. [Electronic resource] / Home / Information Library / Current and Future Generation / Nuclear Power in the World Today. URL: http://www.world-nuclear.org./ (date of access: 07.01.16).

3. World Nuclear Association [Electronic resource]. / Home / Information Library / Nuclear Fuel Cycle / Uranium Resources. URL: http://www.world-nuclear.org./ (date of access: 07.01.2016). 


\title{
СТРУКТУРА РЫНКА ФИТНЕС-УСЛУГ В ОМСКЕ Алексеенко И.В. ${ }^{1}$, Старовойтова А.А. ${ }^{2}$ Email: Alekseenko1791@scientifictext.ru
}

\author{
${ }^{1}$ Алексеенко Ирина Владимировна - кандидат технических наук, дочент; \\ ${ }^{2}$ Старовойтова Анастасия Александровна - кандидат технических наук, дочент, \\ кафедра конструирования и технологии изделий легкой промышленности, \\ Омский государственный технический университет, г. Омск
}

\begin{abstract}
Аннотация: в статье освещается актуальность роста спроса на фитнес-услуги. Представлена классификаиия рассматриваемых услуг в соответствии с действующей нормативно-правовой документаиией Российской Федерачии. Приводятся статистические данные по их объему в структуре платных услуг населению Омска. Представлена характеристика операторов федеральной и региональной сети, а также спортивных организаиий местной фитнес-индустрии. Рассматривается ассортимент услуг спортивно-оздоровительного назначения, предоставляемых фитнес-клубами города. Раскрываются особенности рынка фитнес-услуг в Омске для разработки механизмов его эффективного развития.
\end{abstract}

Ключевые слова: фитнес-индустрия, фитнес-услуги, фитнес-клубы, сетевые операторы, рынок фитнес-услуг Омска.

\section{MARKET STRUCTURE OF FITNESS SERVICES IN OMSK Alekseenko I.V. ${ }^{1}$, Starovoytova A.A. ${ }^{2}$}

\author{
${ }^{1}$ Alekseenko Irina Vladimirovna - Candidate of Technical Science, Associate Professor; \\ ${ }^{2}$ Starovoitova Anastasia Aleksandrovna - Candidate of Technical Science, Associate Professor, \\ DEPARTMENT OF DESIGNING AND TECHNOLOGY OF PRODUCTS OF LIGHT INDUSTRY, \\ OMSK S STATE TECHNICAL UNIVERSITY, OMSK
}

\begin{abstract}
The classification of the services represented in accordance with current regulatory documentation of the Russian Federation. Statistical data for their volume are presented in terms of the structure of paid services to the population of Omsk. Characteristics operators by Federal and regional networks, and sports organizations local fitness industry are presented. The range of services sports and wellness destination, which provide the fitness clubs of the city, considered. Features of the market of fitness services in Omsk to develop mechanisms for its effective development is disclosed.

Keywords: fitness industry, fitness services, fitness clubs, network operators, market of fitness services of Omsk.
\end{abstract}

УДК 339.13.017:796

Все большее количество людей во всем мире уделяет большое внимание здоровому образу жизни и жители нашей страны не являются исключением. Это связано и с повышением уровня жизни россиян, их заботой о собственном здоровье и будущем своих детей, а отчасти и с целевой политикой правительства, направленной на оздоровление нации, воспитание подрастающего поколения в здоровой и благоприятной атмосфере. Специалисты утверждают, что заполняемость рынка фитнес-услуг больших городов России едва дотягивает до $20 \%$, что делает его наиболее перспективным и динамично развивающимся даже при экономической нестабильности $[1,2]$. Однако занятия спортом в современном понимании связаны не только со спортом высоких достижений, интересующем подавляющее большинство граждан с точки зрения зрелищности, азарта или патриотизма. Сегодня это еще и массовый поворот сознания в сторону оздоровления, хорошего самочувствия и бодрости духа.

Индустрия фитнес-услуг становится одним из индикаторов качества жизни людей, их материального достатка, отношения к собственному здоровью. Посещение фитнес-центра становится неотъемлемой частью жизни и играет важную роль в создании имиджа успешного делового человека. В сегодняшней действительности получили распространение относительно новые виды физкультурно-спортивных услуг, которые чаще называют спортивнооздоровительными: аэробика, шейпинг, фитнес, йога, стретчинг, кроссфит, пилатес, тай-чи и 
др. Такие виды спорта чаще всего не связаны с высокими достижениями, интересующими подавляющее большинство граждан с точки зрения зрелищности, азарта или патриотизма, а направлены в сторону оздоровления, хорошего самочувствия и бодрости духа.

В соответствии с Общероссийским классификатором продукции по видам экономической деятельности ОК 034-2014 (КПЕС 2008) рассматриваемые услуги относятся к разделу $R$ «Услуги в области искусства, развлечений, отдыха и спорта», группам «93.11.10 Услуги спортивных объектов», «93.12.10 Услуги, оказываемые спортивными клубами» и 93.13.10 «Услуги фитнес-центров». Согласно ГОСТ Р 52024-2003 фитнес-услуги относятся к группе «Проведение занятий по физической культуре и спорту» [3].

Статистика свидетельствует, что в настоящее время Российская Федерация значительно отстает по показателю регулярных занятий физической культурой от некоторых стран Европы, в которых физическими упражнениями постоянно занимаются до $50 \%$ населения, тогда как в Российской Федерации - только около $8-10 \%$ в Москве и Санкт-Петербурге, в регионах - 2 $3 \%$ [2]. В связи с этим среди основных приоритетов социальной и экономической политики на втором этапе инновационного развития экономики российских городов указывается распространение стандартов здорового образа жизни. Такой подход государственного планирования также отражается в утвержденных правовых документах, направленных на решение региональных стратегических задач развития Омской области [4].

Город Омск - один из ведущих промышленных, транспортных, научно-образовательных и культурных центров России, является административным центром Омской области, расположен в Сибирском федеральном округе Российской Федерации. Численность населения города превышает миллион человек и на 1 января 2017 года составила 1431,8 тыс. чел.

В 2016 году услуги физической культуры и спорта заняли двенадцатое место в структуре платных услуг населению Омска. Их объем составил 541,3 млн руб. [5].

Статистики по фитнесу в России нет. По данным каталога 2GIS в г. Омске на 1 февраля 2017 года функционирует 175 организаций, относящихся к разделам «Фитнес-клубы» и «Тренажерные залы». Позиционируют себя как: фитнес-центры - 8, фитнес-клубы - 7, спорткомплексы - 10, спортклубы - 27, тренажерные залы - 11, студии и школы танца и фитнеса - 19. Также фитнес-услуги предлагают различные учреждения, осуществляющие деятельность в области культуры, спорта, организации досуга и развлечений, такие как: «Центр спортивного досуга «Амбассадор», «Академия единоборств боевых искусств братьев Шеметовых № 1», «Академия здоровья и спорта № 1 Александрия», «Дворец здоровья СибГУФК», «Академия шестовой акробатики и воздушной гимнастики «ДИВАС», спортивный оздоровительно-восстановительный центр «Адреналин-школа Ирины Мартыновой», оздоровительно-гостиничный комплекс «Ника», «Спортивно-концертный комплекс им. В. Блинова», омские ледовые дворцы спорта, профилактории и многие другие.

Многолетними масштабными представителями омского рынка фитнес-услуг являются: спортивный центр «Народный фитнес»; фитнес-центры «Grand Fitness Hall» и «Flex Gym»; центр фитнеса и здоровья «Фитнес № 1»; фитнес-клубы «Эгоист», «Energy Zone», «O2». «Линия жизни»; спортивные клубы «ALEX FITNESS», «Parkfitness». Крупными новичками местного фитнес-рынка в прошедшем году стали: фитнес-клуб «SuperClub» и «Физкультурнооздоровительный комплекс на улице Конева», который построен в рамках социальноориентированной программы «Газпром - детям». К услугам омичей - 25-метровый бассейн, турецкая баня, залы аэробики и групповых занятий, а также тренажерный зал, оборудованные по последнему слову техники; детский уголок и кафе. К открытию в Омске готовится еще один физкультурно-оздоровительный комплекс-«близнец».

Как и в других городах, в Омске присутствуют сетевые клубы. Федеральная сеть «ALEX FITNESS» состоит из 64 современных фитнес-клубов, расположенных в крупнейших городах России. В Омске пока один представитель «ALEX FITNESS», который располагается на Левобережье. Привлекает активная клубная жизнь: фитнес-вечеринки, outdoor-тусовки, внутриклубные спортивные турниры, конкурсы с призами и подарками.

К федеральным сетевикам относится специализированный фитнес-клуб «Народный фитнес». Название клуба говорит о том, что он ориентирован на каждого клиента независимо от его целей, рода занятий и уровня дохода.

Также на омском рынке присутствует федеральная сеть школ танца «Melomano.ru», которая наряду с направлениями современной хореографии предоставляет фитнес-услуги взрослым и детям.

Среди омских сетей лидирует «Flex Gym». Первый клуб был открыт в 2011 году. Сейчас это наиболее крупная и развитая сеть спортзалов в городе. Всего за шесть лет жизни в Омске сеть уже располагает шестью современными клубами, оснащенными всем необходимым 
оборудованием и набором услуг для продуктивных тренировок. Сеть «Energy Zone» уже более 18 лет в городе. Комплекс включает в себя два фитнес-клуба, студию танца и фитнеса, студию моделирования фигуры и салон красоты.

Недавно сеть «Parkfitness» отметила своё 10-летие. Бренд располагает двумя спортивными комплексами, расположенными в разных административных округах города.

На сегодняшний день омичам представлен полный ассортимент современных фитнес-услуг. Мы вполне можем говорить о сложившейся в Омске индустрии фитнеса, в основу которой заложены опыт, знания, сформировавшаяся методическая база и труд количества специалистов.

Анализ состояния рынка фитнес-услуг в Омске показал, что центр города и Кировский административный округ более насыщены фитнес-клубами. Уйти в спальные районы Ленинский, Октябрьский округ, Старую Московку, Старый Кировск - бизнесменам мешает отсутствие площадей. Первое место среди фитнес-услуг по востребованности занимает тренажерный зал с кардиозоной, второе - групповые занятия.

Тренажерные залы в большинстве своем оснащены различными оздоровительными и силовыми тренажерами. Классический силовой тренинг остается базовым трендом уже многие годы и вряд ли когда-либо покинет свою лидирующую позицию рейтинга. Любой спортивный клуб в обязательном порядке имеет кардиозал или кардиозону с так называемыми аэробными тренажерами, так как кардиоупражнения являются обязательным элементом тренировок.

Повсеместно представлены классические групповые фитнес-программы: аэробика (в том числе аквааэробика,) шейпинг, пилатес, калланетика, йога. Распространены фитнес-программы, которые имеют определенную направленность: кик-аэробика, степ-аэробика, танцевальная аэробика, слайдаэробика, стрейтчинг, crunch, табата, чакра-йога, хатха-йога, power yoga, йога-патанджали.

В ассортименте комплексные программы, которые сочетают разные направления фитнеса: пилокс (пилатес плюс бокс); пилоксинг (пилатес плюс танцы плюс бокс); йогалатес (йога плюс пилатес); будокон (йога плюс восточные боевые искусства плюс медитация); зумба (латинские танцы плюс аэробика плюс танец живота); бодитоник (балет плюс йога плюс пилатес); тай-бо (аэробика плюс боевое искусство); тай-чи (оздоровительная гимнастика плюс восточные боевые искусства); тренировочная программа Iron System (Hot Iron плюс Iron Cross) и др.

Пользуются популярностью различные виды тренировок: АнтиГравити - с использованием подвесного оборудования AntiGravity-гамака; Power Stretch - сочетание упражнений на растяжку, силу и баланс, ABS (Abdominal Back Spine) - силовой класс для мышц брюшного пресса и спины; ABT (Abdominal Buttocks Thighs) - тренировка для проработки мышц ног и брюшного пресса; TBW (total body workout) - тотальная проработка тела с сочетанием силовой нагрузки и аэробных упражнений; TRX (Total Body Resistance Exercises) - упражнения общего сопротивления тела с использованием подвесных конструкций (петель); Lower Body - комплекс силовых упражнений на проработку мышц нижней части тела; CardioStrike («крепкое сердце») - тренировка, сочетающая элементы силового тренинга, аэробики, восточных единоборств, кикбоксинга; ABL (Abdominal Buttocks Legs) - силовая тренировка мышц ног, ягодиц и брюшного пресса; Hot Iron (горячее железо) - вид силовых тренировок, в которых применяются мини-штанги; TBS (Total Body Shock) - кардио- и силовой тренинг; Best fit (лучший из фитнесов) - сочетает йогу, кардиотренинг, силовую нагрузку и стретчинг; rope-skipping прыжки через скакалку; Legs\&Butts (иначе называют «фитнес-липосакцией») - проработка традиционно проблемных участков женского тела - ягодиц и ног; вумбилдинг - тренировка вагинальной мускулатуры; функциональный тренинг (functional training) - развитие и укрепление всей нервно-мышечной системы; интервальная тренировка - чередование интенсивных физических упражнений и фаз восстановления сил; кроссфит (CrossFit) - это система функциональных высокоинтенсивных тренировок в сочетании различных спортивных дисциплин; Step pump - тренировка смешанного формата, состоящая из аэробной и силовой частей; Power step - разновидность аэробной тренировки с чередованием динамичных движений на степ-платформе и силовой нагрузки; краткосрочная тренировка - программа длительностью до 30 минут; роуп скиппинг (Rope-skipping) - прыжки со скакалкой и др.

В городе наблюдается перенасыщение клубами среднего ценового сегмента. Стоимость месячного абонемента в любом из них - около 2000 рублей. Чтобы как-то отстроиться от конкурентов, каждый вынужден проставлять акцент на направлениях, методах тренировки и проч. В связи с этим многие спортивные организации предлагают эксклюзивные услуги.

Так, в «Grand Fitness Hall» базируются: крупнейшая в городе школа боевых искусств с рингом и татами, насчитывающая 15 направлений, студия фехтования, школа классического балета, студия TRX, академия сквоша - мяч об стену (сквош-корт - единственный в городе). 
Спортивный оздоровительно-восстановительный центр «Адреналин-школа Ирины Мартыновой» предлагает авторские разработки для коррекции веса и осанки, индивидуальные программы детского фитнеса для детей с избыточным весом, болезнями суставов и спины, для посетителей старше 50 лет с учетом возрастных изменений. Лечебную гимнастику для клиентов и специализированные упражнения для беременных женщин предлагают «Академия здоровья и спорта № 1 Александрия», фитнес-клуб «Лотос» и др.

«Академия единоборств боевых искусств братьев Шеметовых № 1» основана коренными омичами Сергеем и Виталием Шеметовыми - чемпионами мира, Европы и России по единоборствам. В Академии развиваются профессиональные школы кунг-фу, смешанных боевых искусств (Mixed Martial Arts), кикбоксинга, айландского бокса, бразильского джиуджитсу, айкидо, тхэквондо, рукопашного боя.

Семейный спортивный центр «Молния» славится в Омске школой роллеров и крытым роллердромом, залом настольного тенниса и настольного футбола. СЦ «Олимпия» и СК «Строитель» предлагают услуги обучения игре в большой теннис. В СК «Строитель» открыт шайбадром. Сайкл-студия - велотренажеры с экраном, имитация езды на велосипеде по пересеченной местности - работает в фитнес-центре «Grand Fitness Hall», спортивном клубе «Parkfitness», фитнес-клубе «Ритм SPA». В «Академии здоровья и спорта № 1 Александрия» работает специализированная группа армрестлинга. Фитнес-клуб «Атлант» ведет курсы подготовки к ГТО. Услуги зала скалолазания предлагает «Дворец здоровья СибГУФК». Успехов в бодибилдинге достигли: спортивный клуб «Золотой зал», фитнес-центр «Железная шахта». «Академия шестовой акробатики и воздушной гимнастики «ДИВАС» реализует новый вид фитнеса в воздухе. Чемпионки России по воздушно-спортивному эквилибру осуществляют тренировки по воздушной гимнастике на полотнах и кольце. Студия танца и фитнеса «Калинка» предлагает своим посетителям уникальную методику миофасциального релизинга (МФР) как часть тренировки.

На омском рынке присутствуют организации, специализирующиеся на фитнес-услугах для детей и подростков. К ним относятся центр кроссфита «Добрыня»; «Академия здоровья и спорта № 1 Александрия» с детской группой «IRON JUNIOR», направленной на создание мужественного и заботящегося о своем здоровье подрастающего поколения; «Детский игровой клуб «Непоседы» и др. На базе фитнес-клуба «Parkfitness» действует полноформатный детский клуб «Junior Park», работающий по новейшей методике «Интегрированная оздоровительноразвивающая среда». Много предложений для детей от сети «Flex Gym». Школа танцев «ADORE DANCE STUDIO» предлагает услугу «Бэби-фитнес»- фитнес с малышом.

Многие спортивные организации оказывают SPA-услуги для тела: фитнес-клуб «Ритм SPA», «Адреналин-школа Ирины Мартыновой», «Амбассадор», АНО «Авангард», «Азарт», «Линия жизни», «Озон», «Академия здоровья и спорта №1 Александрия», «Пятый элемент», «Т-Фитнес», «Строитель», «Ротор», «Фитнес № 1» и многие др. В ассортименте: бассейны, сауны, хаммам, фитобочка («кедровая бочка»), обертывания, солевые пилинги, ванны, джакузи с гидромассажем, авквафитнес, комплексные СПА-программы и др.

C методической точки зрения популярен персональный тренинг (персональные тренировки). Эффективен персональный тренинг в мини-группах. При этом клиентам предлагается пройти медицинское фитнес-тестирование, что значительно сокращает риск получения травм и помогает правильнее спланировать программу тренировок. Возрастает количество желающих заниматься реабилитационными и оздоровительными программами.

Уже несколько лет образовательные программы для фитнес-тренеров находятся в верхней части рейтинга. И это естественно для развивающегося рынка. На базе «Дворца здоровья СибГУФК» работает профессиональная школа фитнеса. Фитнес-клуб «Лотос» осуществляет обучение инструкторов по фитнесу. В Омске функционирует представительство федеральной сетевой «Школы инструкторов аэробики Варвары Медведевой». Наблюдается изменение структуры фитнес-образования, что обусловлено востребованностью персональных тренировок и комплексных программ оздоровления, ростом популярности коучинга.

Школа правильного питания - это обучающий проект для людей, которые хотят научиться правильно питаться, контролировать свой вес или улучшить свое самочувствие. Некоторые участники омского рынка фитнес-услуг предлагают услуги диетолога, например, «Мадонна», «Energy Zone» и др. Фитнес-клуб для женщин «FitCurves» реализует 30-дневную программу питания для похудения.

Распространение в фитнес-клубах получили фитобары, которые предлагают клиентам различные травяные напитки, чаи, настои, витаминно-минеральные коктейли, а также 
профессиональное спортивное питание. Во многих клубах предлагают услуги массажа, салона красоты.

Большой популярностью пользуются фитнес-услуги в сочетании с услугами по хореографии. В танцевальных школах Омска обучают различным видам танца. Некоторые школы специализируются лишь на одном направлении танца, но в большинстве своем они предлагают широкий выбор танцевальных направлений: стрип-шест Pole-dance (Acrobatic, Artistic, Exotic); Aerial Ring - воздушный танец на кольце; танец на полотнах Aerial Silks; стриппластика Strip-plastica; приватный танец Privat-dance; гоу-гоу Go-Go; танец на каблуках High heels; хип-хоп Hip-hop; брейк-данс Break-dance; дэнсхолл Dancehall; Jazz-funk; тверкинг - бутидэнс Booty dance, бути-шейк Booty shake; восточные танцы; танец живота Belly dance; несколько видов латиноамериканских танцев; черлидинг Cheerleading. Наряду с ними Body ballet - танец с заимствованием элементов из фитнеса, пилатеса и балета; School-фитнес (в программу тренировок включены элементы черлидинга, современной хореографии, гимнастики, акробатики); контемпорари - сочетание элементов западного танца и восточного искусства движения. Фитнес-клуб для женщин «FitCurves» реализует тренировку «Живи танцуя». Студия «Арташат Энзели» предлагает омичам обучение армянским танцам.

Очевидно, что маркетинговая стратегия организаций, оказывающих фитнес-услуги, направлена на сохранение клиентской базы и привлечение новых клиентов. Различные системы разовых, месячных и годовых амбонементов, клубные карты и акции - «Приведи друга», «Первая тренировка - бесплатно», «Привет, студент!», «День рождения - 50\% скидка», «День семьи», «День открытых дверей», «Купить абонемент онлайн со скидкой», «10 минут в подарок», «Скидка к празднику», «Сауна в подарок», «Если Вы не сбросите 3 кг за 12 занятий, то мы вернём Вам деньги!», «Фитнес по стоимости чашки кофе», VIP-карты, подарочные сертификаты и специальные предложения и др. - в условиях финансового кризиса не просто позволяют клубу «выжить», но и открывают дополнительные возможности для его развития.

Следует отметить, что во многих клубах живет дух коллективизма и соперничества. Для сотрудников устраиваются внутренние соревнования между клубами - это позволяет поддержать соревновательный дух и укрепить отношения в команде каждого клуба. Победители получают премии, ценные подарки, признание коллег. Также коллективы спортивных организаций проводят мероприятия городского и регионального уровня для своих клиентов: соревнования, отчетные мероприятия, фестивали.

Для привлечения клиентов многие фитнес-операторы предлагают перечень услуг, связанных не только с фитнесом, но и с досугом: организация дня рождения, детских праздников, корпоративных и туристических мероприятий.

В заключение хочется отметить, что мода на здоровый образ жизни поддерживает фитнесиндустрию даже в кризисные годы. Омский рынок фитнес-услуг находится в стадии формирования, демонстрируя потенциал для развития. Фитнес становится массовым, перестает быть услугой для платежеспособных. Фитнес перестал быть демонстрацией статуса, стал образом жизни. Состояние здоровья, ухоженность, энергичность, личный стиль - вот атрибуты благополучия в будущем. Несмотря на то, что рынок не насыщен, операторы стараются занять уникальные ниши, четко выделить свою целевую аудиторию. Важным становится осмысленный стратегический подход к уникальному позиционированию собственного бренда, который выбирают омские игроки фитнес-рынка. Наилучшие перспективы имеют клубы, предоставляющие широкие возможности для семейного фитнеса, предлагая клиентам широкий спектр сопутствующих услуг, новые групповые и индивидуальные программы, эксклюзивные разработки и оборудование, соответствующее мировым стандартам. В условиях возрастающей конкуренции двигателем фитнес-бизнеса становятся демократичные цены, оснащенность профессиональным оборудованием, широкий выбор вариантов клубных карт, месторасположение клуба и размер залов, хорошая вентиляция, наличие парковки.

\section{Список литературы / References}

1. Боровиков М. Рынок фитнес-услуг 2016 в России: рост вопреки кризису. [Электронный pecypc]. Режим доступа: http://www.buybrand.ru/market-reviews/11989/ (дата обращения: 15.02.2017).

2. Российский рынок фитнес-услуг далек от насыщения: мнение эксперта. [Электронный pecypc]. Режим доступа: http://www.business.ru/article/715-rossiyskiy-rynok-fitnes-uslug-dalekot-nasyshcheniya-mnenie-eksperta/ (дата обращения: 15.02.2017). 
3. ГОСТ Р 52024-2003. Услуги физкультурно-оздоровительные и спортивные.

4. Постановление Администрации города Омска № 938-п от 9 июля 2014 г. «О стратегии социально-экономического развития города Омска до 2025 года». [Электронный ресурс]. Режим доступа: http://www. admomsk.ru/ (дата обращения: 15.02.2017).

5. Интернет-портал Территориального органа Федеральной службы государственной статистики по Омской области (ОМСКСТАТ). [Электронный ресурс]. Режим доступа: http://omsk.gks.ru/ (дата обращения: 15.02.2017).

\title{
ПРОБЛЕМАТИКА ПЕРЕВОДА КОММЕРЧЕСКОГО БАНКА НА ДИСТАНЦИОННОЕ ОБСЛУЖИВАНИЕ КЛИЕНТОВ

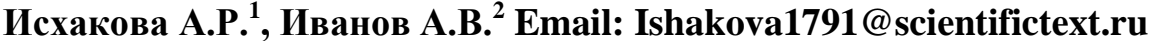

\author{
${ }^{\prime}$ Исхакова Альфия Рафаильевна - студент; \\ ${ }^{2}$ Иванов Андрей Владимирович - кандидат экономических наук, доцент, \\ кафедра электронной коммериии, \\ Федеральное государственное бюджетное образовательное учреждение высшего образования \\ Поволжский государственный университет телекоммуникаций и информатики, г. Самара
}

\begin{abstract}
Аннотация: статья посвящена актуальной теме перевода коммерческих банков на дистанционное обслуживание клиентов. Сегодня в России активно развивается практика дистанционного банковского обслуживания, являющаяся одним из наиболее приоритетных направлений в мировом банковском бизнесе. В статье представлена интерпретаиия результатов исследования системы дистанционного обслуживания клиентов российскими коммерческими банками, обозначены преимущества и недостатки данного вида банковских операций. Выявлены основные причины отказа населения от системы ичифрового обслуживания.
\end{abstract}

Ключевые слова: дистаниионное банковское обслуживание, Интернет-банкинг, мобильный банкинг, финансовые операции, бакновские услуги.

\section{PROBLEMS OF TRANSLATION OF THE COMMERCIAL BANK REMOTE CUSTOMER SERVICE Ishakova A.R. ${ }^{1}$, Ivanov A.V. ${ }^{2}$ \\ ${ }^{1}$ Ishakova Alfiya Rafailevna - student; \\ ${ }^{2}$ Ivanov Andrey Vladimirovich - Candidate of economic Sciences, associate Professor, DEPARTMENT OF ELECTRONIC COMMERCE, \\ FEDERAL STATE BUDGETARY EDUCATIONAL INSTITUTION OF HIGHER EDUCATION POVOLZHSKIY STATE UNIVERSITY OF TELECOMMUNICATIONS AND INFORMATICS, SAMARA}

\begin{abstract}
Today, Russia is actively developing the practice of remote banking services, which is one of the top priorities of global banking. The article presents the interpretation of the results of the study of remote maintenance of clients of the Russian commercial banks indicated the advantages and disadvantages of this type of banking operations. The main reasons for failure of the population from the system digital service.
\end{abstract}

Keywords: remote banking service, Internet banking, mobile banking, financial transactions, bujnowska services.

УДК 336.71

Инновации в банковской сфере, как и в любой другой области экономики, рассматриваются в качестве одного из двигателей прогресса, сути экономического развития. Появление сети Интернет, являющейся глобальным информационным пространством, повлекло технологические изменения в банковском секторе экономики. Благодаря развитию всемирной паутины в 1997 году в США возникла первая система онлайн-банкинга - «Security First Network Bank», а в 1998 году начал функционировать первый интернет-банк в России. В рамках данного сервиса была запущена система «Интернет сервис банк», что положило начало развитию онлайн-банков [1, с. 478]. На данный момент $85 \%$ из 2000 крупнейших компаний мира будут использовать цифровую трансформацию для обеспечения лидерства в своем сегменте. 
В последние годы в России активно развивается практика дистанционного банковского обслуживания, являющаяся одной из наиболее приоритетных направлений в мировом банковском бизнесе [2, с. 90]. Дистанционное банковское обслуживание сегодня представлено технологиями по предоставлению банковских услуг на основании распоряжений, которые передаются клиентом удаленным образом, с использованием различных каналов телекоммуникации - телефонной и мобильной связь, связи посредством локальных сетей либо интернета, технических устройств, таких как банкоматы или терминалы.

В зависимости от канала телекоммуникации можно выделить несколько видов дистанционного банковского обслуживания. РС-банкинг связан с установкой специального программного обеспечения на компьютерное оборудование клиента, что позволит устанавливать связь с самим банком. Интернет-банкинг предполагает использование интернетбраузера для организации доступа клиента к банковским операциям. Преимущества Интернетбанкинга заключается в возможности совершения выписок по своим счетам, получения информации о состоянии денежных средств на карте, по вкладам; по банковским продуктам; подачи заявки на открытие или блокировки депозитов, банковских карт, получения кредитов. Интернет-банкинг дает возможность осуществления внутренних переводов на счета банка либо на счета других банков; конвертировать денежные средства; создавать шаблоны, по которым происходит осуществление регулярных оперативных переводов. Интернет-банкинг представляется привлекательным для физических лиц, так как способствует упрощению ежедневных сделок. Статистика за 2015 год показывает, что 76\% пользователей производят не менее одной финансовой операции посредством Интернет-банкинга в течение месяца [3].

\section{Пользуетесь ли Вы интернет-банкингом хотя бы раз в}

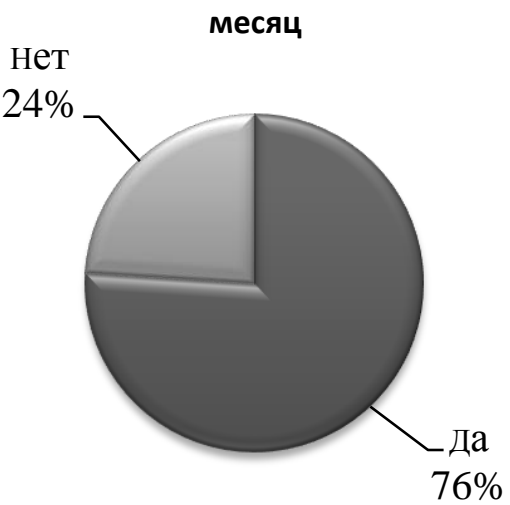

Рис. 1. Статистика пользователей интернет-банкинга

Для телебанкинга свойственно управление счетом при помощи телефонов, имеющих функцию тонального набора. Мобильный банкинг представлен обменом информацией между клиентом и банком через мобильный телефон посредством SMS-сообщений либо мобильногоинтернета. Если ориентироваться на клиентскую базу, то дистанционное банковское обслуживание подразделяется на две группы. Во-первых, речь идет о системах, обслуживание которых распространяется на корпоративный сектор, представленный юридическими лицами и индивидуальными предпринимателями. Во-вторых, стоит выделить системы, которые используются частными, то есть физическими, лицами [7].

Эксперты в сфере банковского дела подчеркивают, что сегодня дистанционное обслуживание развивается быстрее, нежели любое другое направление, так как финансовые операции, осуществляемые с привлечением средств электронной коммуникации являются простыми и комфортными для клиентов [3]. Актуальность дистанционных банковских услуг подчеркивает статистика, результаты которой свидетельствуют о популярности данного вида финансовых операций как среди физических, так и среди юридических лиц. Согласно исследованию, проведенному агентством «Markswebb Rank \& Report» в 2015 году 5,4 миллиона россиян обращаются к услугам Интернет-банкинга. При этом 19,6 миллиона человек в России каждый месяц проводят минимум одну платежную операцию через интернет. 9,4 миллиона жителей России являются пользователями онлайн-, мобильного или SMS-банкинга. 15,4 
миллиона человек используют интернет-банк. 11,7 миллиона человек склонны совершать платежи через интернет-банк за месяц. 8,9 миллиона человек оплачивают в интернете с помощью банковской карты. 7 миллионов жителей нашей страны совершают онлайн-платежи посредством электронных кошельков. 6,6 миллиона россиян в течение месяца могут совершать хотя бы один онлайн-платеж при помощи мобильного устройства [4].

Дистанционное обслуживание является удобной схемой для бизнеса, так как позволяет экономить время при проведении важных финансовых операций. Национальное агентство финансовых исследований изучило, какую роль играет мобильный банк в деятельности бизнесструктур. Исследование показало, что более трети российских предпринимателей предпочитают использовать в своей работе банковское мобильное приложение, причем особенная приверженность услугам интернет-банкинга наблюдается у руководителей небольших и молодых компаний.

Однако, несмотря на отмеченные достоинства перехода банков на дистанционное обслуживание клиентов, до сих пор данные финансовые операции не могут заслужить доверие у ряда граждан. Национальное агентство финансовых исследований подчеркивает, что 40\% россиян не пользуются и не планируют пользоваться доступом к банковским счетам через сеть Интернет. В противовес этому - 17\% опрошенных пользуются и планируют продолжать пользоваться интернет-банкингом [5]. Как видно из рисунка, удобство и комфорт, которые свойственны для дистанционных финансовых операций, не смогли привлечь максимальное число клиентов.

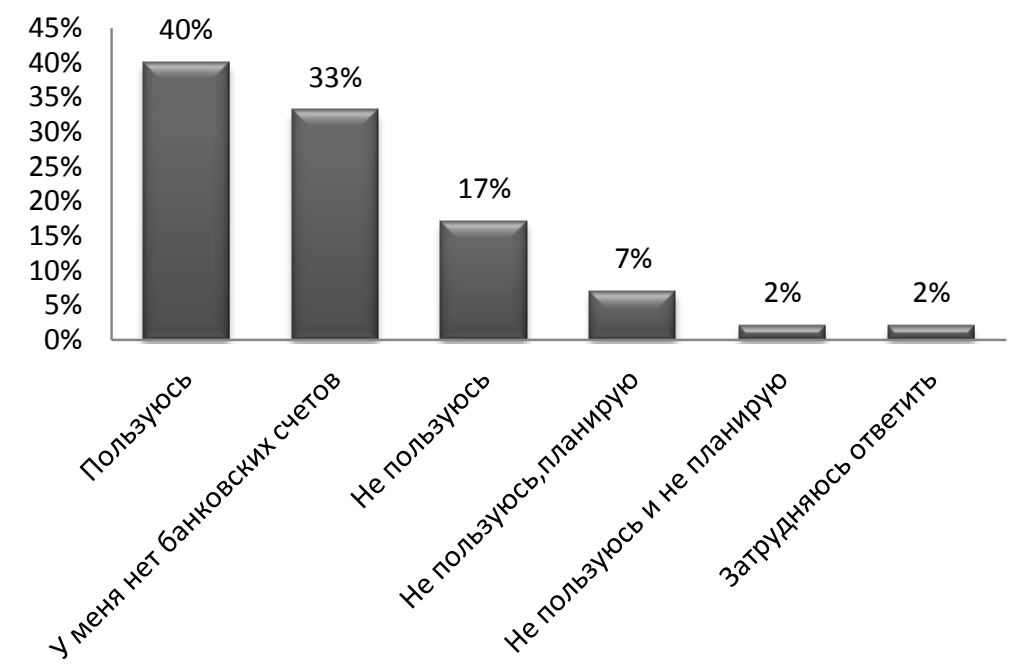

Рис. 2. Распределение пользователей интернет-банкинга в процентном соотношении

Данные Национального агентства финансовых исследований позволили выделить причины недоверия населения к Интернет-банкингу. Основная причина отказа клиентов от Интернетбанкинга связана с тем, что люди рассматривают осуществление платежей через дистанционный сервис как небезопасное, так ответили $48 \%$ опрошенных. $18 \%$ респондентов считают онлайн-банкинг скорее безопасным [6]. 


\section{Насколько опасно или безопасно совершать платежи или проверять баланс с помощью интернет- \\ банкинга?}

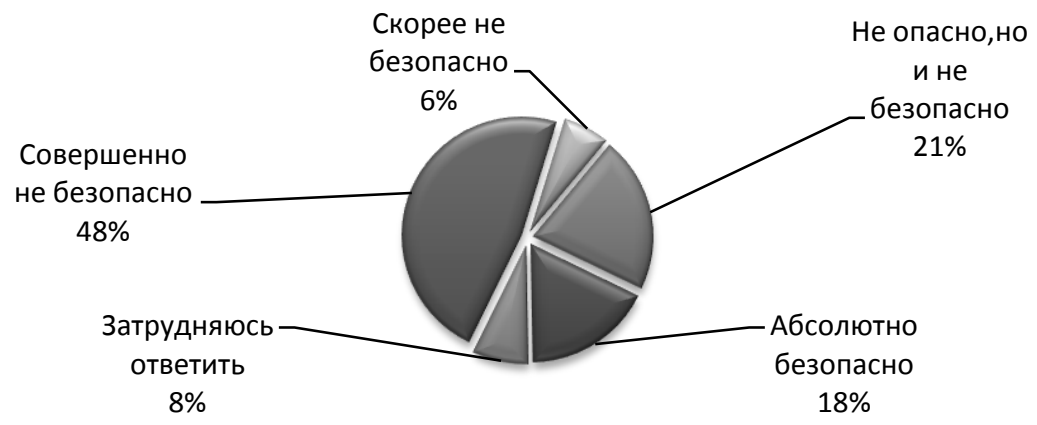

Рис. 3. Распределение использования интернет-банкинга по степени опасности

По мнению исследователей, повышение уровня безопасности использования системы дистанционного банковского обслуживания возможно при кардинальной смене подхода к решению этой проблемы, а именно - при переносе функции контроля параметров документа из операционной системы в замкнутую среду на внешнем устройстве. В этом случае защита, целостность и неизменность документа будут реализовываться не в контексте операционной системы, а в условиях отчуждаемого защищенного носителя.

Помимо недоверия есть и другие причины отказа населения от дистанционного банковского обслуживания, которые удалось обозначить Национальному агентству финансовых исследований, благодаря проведенному опросу: нет потребности пользоваться Интернетбанкингом (39\%), не пользуются Интернетом (29\%), не уверены в надежности сервера (19\%); не умеют пользоваться (19\%); не знают о такой возможности (6\%); требует дополнительных усилий $(4 \%)$; считают комиссию за сервис высокой $(3 \%)$; через Интернет-банкинг невозможно оплатить нужную услугу (1\%) [5].

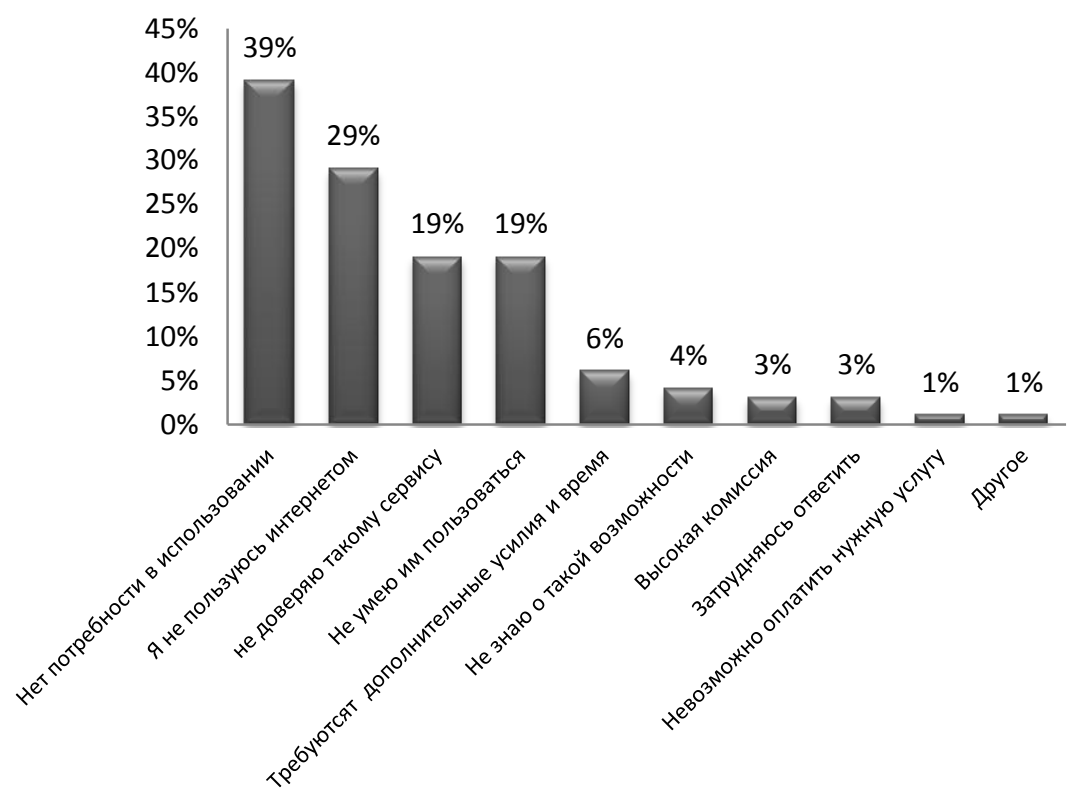

Рис. 4. Распределение пользователей по причинам отказа от интернет-банкинга в процентном соотношении 
Однако система дистанционного обслуживания клиентов банка оперативно совершенствуется, что гарантирует привлечение внимания новых пользователей к данному виду финансовых операций. Являясь оперативными, простыми и удобными, системы дистанционного банковского обслуживания способны обеспечивать клиентам доступ к личным счетам круглосуточно. Дистанционное банковское обслуживание способствует эффективному использованию важнейших ресурсов на сегодняшний день, представленных временем и информацией. Сегодня коммерческие банки, все больше уделяющие внимание качеству сервисного обслуживания клиентов, начинают переходить на дистанционное обслуживание, так как скорость, внимательность и удобство рассматриваются как приоритетные в борьбе за новых клиентов.

\section{Сиисок литературы / References}

1. Льтткина A., Пастухова $K$. Интернет-банкинг и мобильный-банкинг как форма дистанционного банковского обслуживания // Science Time, 2015. № 12 (24). С. 487.

2. Пшеничников B.B., Нетребина М.И. Современные тенденции развития услуг интернетбанкинга для физических лиц (На примере Воронежской области) // ФГБОУ ВПО «Воронежский государственный аграрный университет имени императора Петра I», 2014. C. 90 .

3. Статистика Центрального Банка РФ // Платежи клиентов кредитных организаций с использованием платежных поручений, поступивших в кредитные организации, по способам поступления. [Электронный ресурс]. Режим доступа: http://www.cbr.ru/statistics/p_sys/print.aspx?file=sheet011.htm./ (дата обращения: 11.01.17).

4. Internet Banking Rank 2015. Markswebb Rank \& Report. [Электронный ресурс]. Режим доступа: http://markswebb.ru/e-finance/internet-banking-rank-2015/ (дата обращения: 18.01.17).

5. Неосвоенный интернет-банкинг. [Электронный ресурс]. Режим доступа: http://nacfin.ru/neosvoennyj-internet-banking/ (дата обращения: 15.02.17).

6. Кто пользуется, тот доверяет. [Электронный ресурс]. Режим доступа: http://nacfin.ru/mobilnyj-bank-dlya-biznesa-kto-polzovalsya-tot-doveryaet/ (дата обращения: 25.01.17).

7. Шерстянкина А.А., Хасаншин И.А. Особенности развития интернет-маркетинга в России // Мир науки и новации, 2015. Т. 10. № 2. С. 88. 


\title{
ОБЩНОСТЬ И ТОЖДЕСТВО ЖАНРА ОЧЕРК С РАССКАЗОМ Жусуева С.К. Email: Jusueva1791@ scientifictext.ru \\ Жусуева Сюта Калмаматовна - стариий преподаватель, кафедра кыргызской филологии, \\ Кыргызско-Узбекский университет, г. Ои, Кыргызская Республика
}

\begin{abstract}
Аннотация: в статье рассмотрены специфические особенности жанра очерк, как тождественного рассказу художественно-публичистического произведения, анализируются пути формирования данного жанра в профессиональной кыргызской литературе. Исследованы художественные и публицистические особенности очерка, его общность и различие с рассказом. Основываясь на жанровой природе очерка в литературе, определено, что очерк есть типизачия события, написанная в художественном стиле, без видимых украшений, рассказ - о настоящих проблемах, с участием живых типических образов.
\end{abstract}

Ключевые слова: очерк, художественный стиль, публицистичность, образность, главный предмет, композиция, авторская идея, жанровая специфика.

\section{GENERALITY AND IDENTITY OF ESSAY GENRE WITH STORY Jusueva S.K.}

\author{
Jusueva Syuta Kalmamatovna - senior lecturer, \\ DEPARTMENT OF KYRGYZ PHILOLOGY, \\ KYRGYZ-UZBEK UNIVERSITY, OSH, REPUBLIC OF KYRGYZSTAN
}

\begin{abstract}
: this article is deals with the subject genre of the essay as an identical story piece of art and analyzes the formation of the genre of essay in the professional Kyrgyz literature. The article is investigated belles-letters and journalistic features of the essay and its generality and differences with stories. It based on genres nature of essay in literature and it was defined that essay is a types of events which written in belles-lettres style, effortless embellish, story of real problems taking part in vivid typical images.
\end{abstract}

Keywords: essay, belles-lettres style, journalistic, imagery, main item, composition, authors idea, genre's feature.

УДК: 894.2.341:82-3/-9(575.2)(04)

Как и все жанры литературы, виды искусства, очерк имеет свой главный предмет: это показать человека и его жизнь, описать портрет героя сегодняшнего дня в различных жизненных обстоятельствах. Очеркист обязан создать произведение, способное оказать на читателя сильное воспитательно- познавательное воздействие, отойдя от простых восхвалений, реально, жизненными фактами описать характер героя, его работу, судьбу, конкретно показать его труд и отношение. В свое время художник слова М. Горький отмечал: «Самое главное, важное для нас - это необходимость создания легких в понимании, обоснованные достоверными фактами, очерк и публицистика. Что бы мы не писали, стержнем этих произведений всегда должны быть живые люди». Таким образом, главный предмет очерка человек, человек как носитель событий ставится на первый план [3]. Значит, создание образа нового человека, являющегося предметом художественного наблюдения, отражение острой проблемы дня и описание истории какой-либо страны живыми сведениями определяет специфические обязанности жанра очерк.

Итак, очерк - дважды боевой жанр: «Несет ответственность», с одной стороны, по законам художественных произведений, с другой - публицистики и научных произведений. Его особенность и ценность заключается именно, в этом. Очерк располагает лаконичностью, типизацией образов, эстетическим оцениванием, имеет своеобразное сюжетное и композиционное строение, языковую и стилистическую особенность.

Проблемы различия очерка и рассказа являются спорными и интересуют многих ученыхлитературоведов. «Способный тягаться с разведкой» (В. Овечкин), «возникший на стыке рассказа и исследования» (М. Горький). Были случаи, когда литературоведы в определении жанровой природы очерка, имея разные точки зрения, оказывались по обе стороны баррикады. 
Проблема заключается в том, какое качество очерка - художественность или публицистичность, является руководящей. Эти качества: «смешение природы образа с жизненными фактами» (Ү. Касыбеков), дополняя друг друга, повышают художественную ценность очерка, умножают его значимость. Исследователь или литературовед, обратившийся к жанровой природе очерка, не может не столкнуться с данной проблемой.

В 1928 - 1929 годы в журнале «Наши достижения» шли горячие обсуждения о жанровой специфике очерка. В 1934 году В. Бобрышев опубликовал большую статью «Очерк большая литература», в ней он ставил вопросы о «различии очерка и рассказа, о необходимости сюжета и фантазии, как спаять художественную поэтику с цифрой и фактами, что такое публицистичность и оперативность?» Основатель теории и практики очерка в советской литературе, М. Горький, определил, что очерк есть «художественное произведение, но отличающееся припаянностью к публицистике, о близости очерков рассказам у некоторых очеркистов», «очерк имеет полноценную художественную ценность, в то же время это жанр, отвечающий требованиям времени», «очерк с одной стороны примыкает к публицистике, с другой - рассказу, особый жанр, неспособный заменить ни рассказ, ни публицистику». В 1950 60 годы данный вопрос снова поднимается среди прозаиков, литературоведов и критиков: «если считать очерк публицистикой, можно ли публицистику назвать художественным произведением, как различать очерк и рассказ?» [4]. Вокруг таких вопросов шли спорные толкования. Если большинство значение очерка сводило к публицистике, то некоторые считали художественным произведением, приблизив рассказу.

Ю. Суровцев в статье «Очерк - это публицистика», опубликованной 25 апреля 1958 года в «Литературной газете» выразил мнение: «Очерк - это или просто публицистика, или художественная публицистика, но все равно публицистика». А те, кто считает очерк «художественным произведением», в целях утверждения своих мыслей, приводят в качестве примеров художественные очерки великих русских писателей Короленко Г., Успенского, Салтыкова-Щедрина, Горького, Серафимовича и др. [4].

Если ученый - литературовед А. Эркебаев не считает очерк малым жанром, то К. Асаналиев придерживается мнения, что «очерк нельзя понимать как жанр, состоящий из списка сухих фактов, это вид высокого искусства, показывающий содержание жизненных обстоятельств». Итак, остановимся на сочетании художественности и публицистичности: художественность - специфический признак творческих произведений, форма красоты в искусстве, высокое представление эстетики. Художественность, в широком смысле слова в отличии от форм общественного сознания, образное, художественное отражение действительности в искусстве. Нет искусства без художественности. Основной и главный источник художественности - показ жизненных проявлений в образной форме, и возможность донести свои мысли и чувства в этом направлении.

Публицистичность - это не специальный жанр вроде публицистики, просто отражение внутри художественного произведения проблемных вопросов времени, острых проблем общественной жизни Публицистика (лат. - общественный) - дневник в литературе, особый острый жанр, написанный силой художественного слова, направленный против общественно-политических, актуальных проблем времени [1]. Таким образом, если подытожить точки зрения ученых о своеобразии жанровой специфики очерка, то очерк - последовательное повествование событий с участием типичных, живых образов, написанное в художественном стиле, свободно использующий художественные языковые средства, выявляющий злободневные вопросы времени. Характерные различия очерка и рассказа в следующем: рассказ как очерк не показывает конкретное событие, конкретного человека (героя), а показывает типы людей и событий такого рода. Иначе говоря, рассказ создается не на основе документальной действительности, а на основе авторского вымысла. Это не значит, что рассказ не имеет правдивых истоков. Авторский вымысел является представлением известных жизненных событий, действительности. При создании рассказа автор выбирает те общие качества событий и героев, которые принадлежат всем и типизирует их. А в очерке и герой и событие - известное проявление конкретной действительности. Например, если очеркист пишет о шахтере, то шахтер - это человек, работающий на шахте, обладающий определенными чертами характера, мыслями. Иначе говоря, очерк имеет свой точный адрес. Общее между рассказом и короткими повестями заключается в следующем: и очерк и рассказ как и повесть пишутся формой литературного художественного языка, и в них широко используются портретные характеристики, пейзажные описания, психологизм. Схема построения как у рассказа: имеет экспозицию, завязку, кульминацию, развязку. Если в рассказе линия построения образа длится от начала произведения до его конца, в очерке то же самое, хотя даже построение образа здесь ставится на первое место [2]. В 
прозаических произведениях известные образы людей, типичные характеры, их диалектический рост рисуется силой художественного слова. Значение и содержание, идейная особенность очерков несут на себе, именно, эти обязанности. Хотя в большинстве случаев основным объектом очерка является работа человека, его назначение и достижение, известно, что он не может существовать без человека, его живого портрета. Иногда в очерке писатель, собрав несколько родственных событий, создавал характерный образ, тип. Таким образом, очерк и рассказ перекликаются, но в известной степени имеют и различия. Например, если некоторые критики объясняют эти различия документальностью очерка, то другие указывают, что это представление современной жизни. Но и в рассказах, повестях требования дня, проблемы времени и документальные события могут быть вполне реальными.

Первые очерки не отвечали требованиям жанра, иногда они были как репортажи, возникшие из журналистских расследований. Но нельзя не упомянуть о настоящих очерках: «Украина в военные дни» Ж. Бөкөнбаева, «ЖизньТоктогула» К. Баялинова, «Мои предложения господину Поинтону», Т. Байжиева «Күрөш», А. Токомбаева, «Письмо от Бээжина», и др., очерки К. Маликова, С. Сасыкбаева, также создание замечательных путевых очерков К. Жусупова («Образы Японии», «В стране Микеланджело» и др.). Портретные очерки А. Матисакова («Лицо кыргыза - лицо Сүймөнкула»). Большой вклад в активизацию жанра в кыргызской литературе сыграли очерки Ч.Айтматова, затрагивающие социально-нравственные проблемы [4]. Более точнее сказать: интересные образцы очерковых произведений в кыргызской литературе стали создаваться со времен Великой Отечественной войны. Свое развитие жанр получил в 60-80 годы, когда появился ряд очерков, отражающих тему народного хозяйства, производства.

А. Таабалдиев в статье «Об особенностях публицистики» определяет такие различия: «Очерк не останавливается на всех проблемах дня, а останавливается на самой острой и новой из них. Он находит разные проявления, первую ласточку жизни, вопросы, проблемы, вносит в литературу новых живых героев дня и выносит на суд общества. Очерк своим повествованием нового называется боевым жанром - разведчиком. А рассказ по-своему способен показывать все это после их распространения, после того, как все становится типичным, характерным. В связи с этим авторское отношение к разным новым проявлениям, которое является объектом очерка, показывается открыто и прямо. А рассказ же, описывая характерные стороны жизни, отношение автора, его мысли, в основном передает их через известные образы» [5]. В статье Шаршенбек Уметалиев «Кыргызская литература за сорок лет» (Ала-Тоо, № 11, ноябрь, 1957), писал о месте жанра очерка в кыргызской литературе: «Известно, что художественный очерк в литературе легкий и лаконичный, позволяющий смешаться с жизнью, самый оперативный жанр. Активностью в повседневной жизни, связывая с ней массы, художественный очерк играет большую роль в пропаганде всего передового, в умении точно показывать недостатки. Настоящий художественный очерк знакомит с жизнью и ведет в нее».

Подытожим вышесказанное:

В рассказе писатель:

1) собирает жизненные проявления, изучает их, обобщает, создает типичный образ, рисует героя с типичных людей;

2) мысли и идея автора передаются на основе жизненных событий, действительности;

3) событие плавно развивается, обладает эстетическим сюжетом;

4) значимая мысль вложена в малое содержание.

Сложность жанра очерка в этом.

Особенности очерка:

1) Документальность, факты, цифры, реальная личность, правдивое событие, точный адрес;

2) отражение важного острого вопроса дня;

3) выполнение роли агитации, пропаганды (борьба народа, преданность устарело отечеству и производству);

4) требует художественного анализа; сочетания образности и публицистичности;

5) Универсальность: обращение ко всем проявлениям жизни, рисует нравственносоциальные, политико-экономические, природные явления.

Общность и различие рассказа и очерка:

- Малые формы эпического рода;

- Главный предмет - человек, его жизнь;

- Ограниченность героев; 
- Композиционное строение, одинаковая сюжетная линия (авторское повествование, переживание, конфликт, описание пейзажа, тема дня, сюжетное ответвление: зачин, завязка, кульминация, развязка);

- Описываются только значимые моменты жизни человека;

- Создается образ, раскрывается характер героя, описывается портрет;

- Художественные языковые средства;

- Требование дня, отражение проблемы времени;

В кыргызской литературе первые очерки рассматривались как произведения, подобные рассказам. Например, очерки А. Токомбаева «Тянь-Шаньский разведчик», С. Сасыкбаева «Нурлан», А. Убукеева «Кыз-жигит», Ж. Таштемирова «Третья бригада», М. Элебаева «Буранный день», М. Токобаева «На колхозном пастбище» и др. можно назвать похожими по содержанию и объему на рассказ.

\section{Список литературы / References}

1. Муратов А., Шериев Ж., Исаков К. Кыргызская литература: справочник. Бишкек, 2014. С. 125.

2. Осмоналиев К. Жанровая эволюция кыргызского очерка. Ф. «Кыргызстан», 1980. С. 7-9.

3. Станбеков О. Жанры журналистики. 1часть - Жалал-Абад, 2002. С. 27.

4. Жусуева С. Социально-нравственные проблемы в очерках Ч. Айтматова. Материалы Межд. научно-практ. конф. «Айтматовские чтения-2016». Бишкек, 2016. С. 321-322, 255.

5. Табалдиев А. Памятник Октябрю. Фрунзе. «Кыргызстан», 1985. С. 221. 


\title{
СИСТЕМА ГОСУДАРСТВЕННОГО И ОБЩЕСТВЕННОГО ПРОТИВОДЕЙСТВИЯ НЕЗАКОННОМУ ОБОРОТУ \\ НАРКОТИЧЕСКИХ СРЕДСТВ В КЫРГЫЗСКОЙ РЕСПУБЛИКЕ Ботобаев A.A. Email: Botobaev1791@scientifictext.ru
}

\author{
Ботобаев Адильбек Айдарбекович - полковник милиции, начальник, \\ Главное управление уголовного розыска Министерства внутренних дел Кыргызской Республики, \\ 2. Бишкек, Кыргызская Республика
}

\begin{abstract}
Аннотация: в настоящей статье рассматриваются вопросы применения мер государственного противодействия незаконному обороту наркотиков, исследуются положительные и отрииательные стороны борьбы всех органов с распространением наркотизма. Исследуются основные группы мер и способов, направленных на борьбу с распространением наркотиков в Кыргызстане. В статье автор отмечает о различии мер, способных максимально снизить динамику роста наркотизма, и противостояния наркопреступности. Прежде всего, указывается на меры, связанные с привлечением общественности и гражданского населения к проблеме, а также меры, направленные на координацию деятельности не только правоохранительных органов, но и государственных, в борьбе с распространением наркопреступности.
\end{abstract}

Ключевые слова: общество, государственные меры, наркотики, наркобизнес, меры противодействия, международные организаиии.

\section{THE SYSTEM OF STATE AND PUBLIC COUNTERACION TO ILLEGAL TURNOVER OF GRUGS IN THE KYRGYZ REPUBLIC Botobaev A.A.}

\author{
Botobaev Adilbek Aidarbekovich - colonel of militia, the chief, \\ CRIMINAL INVESTIGATION DEPARTMENT OF THE KYRGYZ REPUBLIC, \\ BISHKEK, REPUBLIC OF KYRGYZSTAN
}

\begin{abstract}
: this article deals with the application of measures of state influence drug trafficking, explores the positive and negative aspects of combating the spread of drug addiction of all organs. We study the basic groups of measures and techniques, aimed at combating drug trafficking in Kyrgyzstan. The author points out the difference measures that can minimize the growth dynamics of drug addiction and drug-related crime confrontation. First of all, it points to the measures connected with the involvement of the public and the civilian population to the problem, as well as measures aimed at coordinating the activities of not only law enforcement but also the public in the fight against the spread of drug-related crime.
\end{abstract}

Keywords: society, state measures, drugs, drug trafficking, counter-measures, international organization.

УДК 343

Мировое сообщество разработало огромный механизм мер противодействия наркомании, наркотрафику и наркобизнесу. Следует отметить, что так уж сложилось, что основным борцом с данными и иными антиобщественными явлениями выступает государство. Именно оно взяло на себя функции предупреждения, профилактики, борьбы и наказания. Если ранее огромное влияние оказывала религия, то период глубокого атеизма привел к кардинальному изменению сознания граждан и необходимости именно государственного вмешательства. Соответственно, государство осуществляет практически весь системный комплекс мер противодействия. Так уж сложилось, что система этих мер превратилась в единую государственную политику, вбирающую в себя различные сферы, такие как деятельность правоохранительных органов, работу специализированных медицинских и образовательных учреждений, социальных служб, пограничных войск, а также привлечение общественных институтов, таких как религия, средства массовой информации, организации культуры и бизнеса. Особо следует отметить деятельность международных организаций. Во многих странах данная программа вылилась в 
долгосрочные государственные программные документы, реализация которых вменена в обязанность ответственных лиц и учреждений.

Анализ этих программных документов показывает, что этот комплекс мер включает в себя, главным образом:

1) Государственные органы, наделенные определенными полномочиями в сфере противостояния данному виду антиобщественного явления и ему сопутствующих;

2) Систему мер реагирования государственных и общественных институтов на распространение наркомании, наркотрафик и наркобизнес. При этом следует отметить, что данные меры различны. Важное значение имеют органы внутренних дел, как основные борцы с противоправными действиями. Исторически сложилось, что именно они брали на себя важнейшие задачи по профилактике, борьбе и искоренении наркомании, наркотрафика и наркобизнеса. Такая ситуация складывалась до тех пор, пока в Кыргызстан наплывом не ринулись наркодельцы, перевозящие афганский «герыч». Это случилось в конце 80-х годов прошлого столетия. Обретение независимости, решение более весомых политических задач отложили ненадолго решение этой острой проблемы и только 8 апреля 1993 года Указом Президента КР был создан специализированный орган - Государственная комиссия КР по контролю наркотиков. На данный орган была возложена задача контроля законного оборота наркотиков [1]. Этот орган пережил определенные изменения, вплоть до его закрытия в 2009 году. Однако, специфика Кыгрызского наркотрафика потребовала кардинального изменения ситуации: в 2010 году была создана Государственная служба по контролю наркотиков, которая классифицировалась как «специализированный правоохранительный орган в области оборота наркотических средств, психотропных веществ и прекурсоров, противодействия их незаконному обороту» [2].

Среди компетенций данной службы выделим некоторые, которые ключевым образом определяют ее место среди государственных органов. Прежде всего, реализация эффективной политики в сфере борьбы с незаконным оборотом наркотиков, пресечение, предупреждение, расследование подобных составов, координация деятельности и взаимодействия всех смежных органов в данной области. Кроме того, это участие Кыргызской Республики на международной арене в области противодействия незаконному обороту наркотических средств, психотропных веществ и прекурсоров [3].

Учитывая те задачи, которые стоят перед данной службой, в 2013 году был принят Закон КР Об органе Кыргызской Республики по контролю наркотиков от 11 марта 2013 года № 39, который определяет правовой статус, задачи, и функции органа по контролю наркотиков, а также порядок прохождения службы в этой структуре. Уровень законодательного регулирования вопросов правового статус этого органа уже сам по себе свидетельствует о том значении, которое придает Правительство вопросам борьбы с наркоманией и наркотрафиком.

В ходе своей повседневной деятельности ГСКН набрал огромный опыт. Под влиянием и с представления этого органа были внесены существенные коррективы в базовый документ Закон о наркотических средствах, психотропных веществах и прекурсорах, принятый в свое время Законодательным собранием Жогорку Кенеша Кыргызской Республики 24 апреля 1998 года, в редакции Законов КР от 4 июля 2005 года № 90, 2 марта 2010 года № 40.

Данный закон закрепляет государственное право на контроль за деятельностью в сфере законного оборота наркотических средств, психотропных веществ и прекурсоров, в частности им определены основания и порядок лицензирования и иной разрешительной деятельности в этой сфер. Законом определен и комплексный механизм борьбы с незаконным оборотом и потреблением наркотических средств, психотропных веществ и прекурсоров.

Следует отметить, что законодательство жестко разграничивает и классифицирует меры государственного воздействия на следующие: меры противодействия незаконному обороту наркотических средств, психотропных веществ и прекурсоров и меры противодействия незаконному потреблению наркотических средств или психотропных веществ. Отметим, что данный комплекс мер не является окончательным. Эти меры подкрепляются целой системой мер уголовно-правового характера, предусмотренных Уголовным кодексом КР от 1 октября 1997 года № 69 и дополненных мерами административно-карательного характера, предусмотренных Кодексом КР об административной ответственности от 4 августа 1998 года № 114.

В настоящее время идут общественные слушания Закона Кыргызской Республики «О внесении изменений и дополнений в Закон Кыргызской Республики «О наркотических средствах, психотропных веществах и прекурсорах», который одобрен и внесен на рассмотрение в Жогорку Кенеш КР Постановлением Правительства КР от 29 августа 2014 года № 508 и предполагает внесение корректировок, связанных с изменением законодательства о 
лицензионно-разрешительной системе в Кыргызской Республике и членства Кыргызстана в Таможенном Союзе.

В целях обеспечения эффективной деятельности ГСНК КР Правительством КР принят целый блок нормативных актов, регламентирующих деятельность данной службы. К их числу следует отнести Правила осуществления государственного контроля над оборотом наркотических средств, психотропных веществ и прекурсоров в Кыргызской Республике от 22 июня 2004 года № 466, Порядок учета, хранения и использования наркотических средств, психотропных веществ и прекурсоров в Кыргызской Республике от 18 февраля 2011 года № 54, Постановление Правительства Кыргызской Республики «О порядке учета, хранения и использования наркотических средств, психотропных веществ и прекурсоров в Кыргызской Республике» от 18 февраля 2011 года № 54 и иные документы.

Законотворческая работа по исследуемой проблеме поставила перед ГСКН КР определенную задачу по реализации Программы по переходу Кыргызской Республики к устойчивому развитию на 2013 - 2017 годы в пределах ее компетенции и сферы деятельности. Этот план включает в себя комплекс мероприятий, среди которых, на наш взгляд, особо следует выделить цель взаимодействия и обеспечения сотрудничества правоохранительных и иных государственных органов с гражданами и институтами гражданского общества в противодействии незаконному обороту наркотиков и их прекурсоров, обнаружении мест произрастания дикорастущих наркосодержащих растений и фактов их незаконного выращивания, выявлении и пресечении коррупционных связей, способствующих ГСКН 31 декабря незаконному обороту наркотиков и их прекурсоров» [4]. Эти меры по взаимодействию различных органов в процессе их деятельности по противодействию распространению наркотрафика в стране, должны определяться, прежде всего, на всемерном ограничении для населения доступности наркотических средств и психотропных веществ. Таким образом, основные позиции государственной борьбы должны быть заключены на предотвращении ввоза нелегальных наркотиков в страну, эффективным изъятием наркотиков из нелегального оборота, предупреждением утечки наркотических средств, психотропных веществ и прекурсоров из легального оборота в нелегальный.

Но данное направление является лишь одной из точек соприкосновения взаимодействия государственной службы и институтов гражданского общества. Анализ официального сайта КСНК КР показывает, что таких точек взаимодействия достаточно много, и они осуществляются по целому ряду направлений.

Общественность, в том числе и в лице общественных организаций, вовлекается в процесс борьбы с наркоманией и наркобизнесом. Общественные институты подключаются к процессу агитации населения государства к ведению здорового образа жизни, воспитания молодежи в духе свободы от наркозависимости и наркосреды, по формированию устойчивого неприятия наркотиков верующими и их близкими. Кроме того, большое предупредительное значение имеют упрочение мнения и веры населения в большом и необратимом вреде наркотиков, а также повышение культурного быта и межличностных отношений в среде различных социальных слоев и возрастных категорий. Такого рода социальный контроль является существенным дополнением к деятельности государственных органов.

Практика показывает и доказывает невозможность борьбы государства с наркопреступностью без деятельного участия сознательного гражданского общества. Здесь, среди важнейших способов и мер, которые нам еще предстоит решать, есть меры, направленные на значительное расширение привлечения общественных институтов при реализации конкретных антинаркотических проектов, отвечающих государственным интересам в целом. Следует признать, что только согласованная деятельность всех правоохранительных органов, действенное использование сил и средств, приведет в конечном счете к положительным результатам, следствием которого станет стабилизация наркоситуации в стране.

В течение последних нескольких лет в стране постоянно муссируется вопрос о неэффективности деятельности ГСКН, а также необходимости ликвидации этого органа с передачей его функции МВД КР. Так, Межведомственная комиссия по изучению деятельности ГСКН 2012 года констатировала, что «...за текущий год в ГСКН не было проведено ни одного заседания коллегии. «Отсутствует документация по взаимодействию с другими силовыми структурами. В ведомстве существует 112 штатных единиц, из которых 21\% является вакантным. Нагрузка работы составляет всего $0,4 \%$ на одного оперуполномоченного сотрудника. Есть подозрение на мнимые поставки наркотиков с юга на север страны. Также полностью отсутствует порядок хранения и уничтожения вещественных доказательств. Официально подтверждено, что не зарегистрированными остались вещдоки по 7 уголовным делам» [5]. 
25 июня 2015 года также была создана межведомственная комиссия по изучению деятельности ГСКН КР, которая установила, что в ведомстве работа не ведется на должном уровне. Так, экс-Премьер-Министр КР Т. Сариев заявил, что: «Прежде всего, конфликт между первыми лицами ГСКН внес существенный раскол и дисбаланс в деятельности всей службы. В моей практике не было примеров, когда руководитель государственного органа и его заместители жаловались друг на друга. За период проверки деятельности ГСКН, пройденные работы по проверке свидетельствуют о неэффективности всей Службы». В частности комиссия установила, что «ГСКН не проводил масштабных спецопераций по пресечению деятельности крупных наркоканалов с изъятием значительного веса тяжелых наркотиков и привлечением к ответственности всей цепочки преступников от исполнителя до организатора» [6].

Однако, отечественные и зарубежные эксперты достаточно критично относятся к предложению о ликвидации ГСКН. Так, А. Зинченко, анализируя ситуацию и ее возможные последствия, заявляет, что «МВД - это орган, который ведет ежедневную рутинную работу, борется без определенных стратегий, концепций, без учета ситуации. Многие годы мы были, образно говоря, «под героиновым зонтиком», он нас накрыл, и мы научились с этим как-то бороться, противостоять. И вдруг этот зонтик перестает существовать, это глобализация, во всем мире появляются новые наркотики, очень трудно будет новому органу бороться с ними, а вот в ГСКН эту работу уже начали, они ищут новую информацию, начали приглашать экспертов, обучать врачей, как реабилитировать этих людей, как лечить, как проводить профилактику, выявлять эти вещи. Этот орган реагирует гораздо быстрее. Россия приняла такое непопулярное решение упразднить ФСКН, и мы как бы пытаемся идти за ними. У России нулевая толерантность по отношению к наркозависимым, она их считает преступниками. В Кыргызстане совершенно другой подход, мы вплотную работаем с наркозависимыми. Борьба с незаконным оборотом наркотиков несколькими службами несет положительный эффект. Например, в США 16 служб, так или иначе, занимаются наркотиками, а это конкуренция, они контролируют работу друг друга» [7].

Общественный совет при ГСКН считает преждевременным, ошибочным и даже опасным решение по ликвидации службы. В его обращении к Президенту Кыргызстана отмечено: «Общественный совет при ГСКН в целом поддерживает инициативы правительства, Совета обороны в проведении реформ в правоохранительных органах в условиях экономической нестабильности, дефицита бюджета. Но считает преждевременным, ошибочным и даже опасным решение по ликвидации ГСКН, предназначение которой - организация и обеспечение скоординированной целенаправленной борьбы с распространением наркотиков и наркобизнесом, разработка и реализация сбалансированной наркополитики, международное сотрудничество в противодействии транснациональной наркоэкспансии. ... Общественный совет ГСКН считает, что ликвидация и переформатирование ГСКН, фрагментированное делегирование разноплановых функций ГСКН (законный, незаконный оборот наркотиков, международное сотрудничество, коммуникация, профилактика и многое другое) приведут не к улучшению координации в сфере противодействия наркотикам, а к декоординации всей антинаркотической работы» [8].

Принятие конечного решения остается за Президентом. Но, по нашему мнению, страной накоплен определенный опыт борьбы с наркотрафиком и наркобизнесом. Действительно, борьба с этими явлениями комплексной работой целого ряда служб, в том числе и МВД, Пограничная служба, Министерство здравоохранения, местные исполнительные и представительные органы власти и др. Мировая практика многих стран позволяет констатировать, что такое противодействие требует серьезной координации деятельности этих служб. И действительно, та спонсорская и организационная поддержка международных организации и зарубежных стран будет эффективной при наличии определенной государственной системы, желательно привычной для них. Другой вопрос, что необходим действенный контроль за процедурами отбора, расстановки, карьеры сотрудников ГСКН и другими служащими имеющими доступ к оперативным сведениям и каналам.

\section{Список литературы / References}

1. Указ Президента КР № 115 от 8 апреля 1993 года.

2. Указ Президента КР «Об образовании Государственной службы Кыргызской Республики по контролю наркотиков от 17 августа 2010 года» УП № 131.

3. Указ Президента КР Вопросы Государственной службы Кыргызской Республики по контролю наркотиков от 27 сентября 2010 года УП № 204. 
4. План мероприятий Правительства Кыргызской Республики на 2014 год по реализации Программы по переходу Кыргызской Республики к устойчивому развитию на 2013-2017 годы.

5. Отчет Межведомственной комиссии по изучению деятельности ГСКН. [Электронный pecypc]. Режим доступа: http://www.kchr.org/modules.php?name=News\&file=article\&sid=3995/ (дата обращения: 25.02.2017).

6. Премьер-министр освободил от занимаемой должности председателя ГСКН при Правительстве КР Алымбая Султанова. [Электронный ресурс]. Режим доступа: http://www.gov.kg/?p=58622\&lang=ru/ (дата обращения: 25.02.2017).

7. Александр Зеличенко: Сейчас происходит передел наркосцены. [Электронный ресурс]. Режим доступа: http://24.kg/obschestvo/33077_aleksandr_zelichenko_seychas_proishodit_perede 1_narkostsenyi/ (дата обращения: 25.02.2017).

8. Ликвидацию ГСКН назвали ошибочным и опасным решением. [Электронный ресурс]. Режим доступа: http://zanoza.kg/doc/341014_likvidaciu_gskn_nazvali_oshibochnym_i_opasnym _resheniem.html/ (дата обращения: 25.02.2017).

\title{
ХАРАКТЕРИСТИКА НАРКОСИТУАЦИИ В КЫРГЫЗСТАНЕ НА СОВРЕМЕННОМ ЭТАПЕ
}

\section{Ботобаев A.A. Email: Botobaev1791@scientifictext.ru}

\author{
Ботобаев Адильбек Айдарбекович - полковник милиции, начальник, \\ Главное управление уголовного розыска Министерства внутренних дел Кыргызской Республики, \\ г. Биикек, Кыргызская Республика
}

\begin{abstract}
Аннотация: в настоящей статье рассматриваются злободневные и актуальные вопросы наркомании в Кыргызской Республике и связанные с ними проблемы подрыва здоровья нации вследствие глобального распространения наркотиков, борьбы с наркозависимостью и вовлечения в нее все новых людей. Приводятся экспертные данные и анализируются оценки по создавшемуся через Кыргызстан наркотрафику. Исследуются основные направления государственной политики в отночении наркобизнеса. Большое внимание уделено исследованию вопроса противодействия распространению наркотрафика через Кыргызстан 8 другие государства, в частности Россию. Приводятся статистические данные и динамика увеличения числа наркозависимых людей и связанных с ними иных острых сочиальных проблем: распространение ВИЧ, гепатит, низкая рождаемость и высокая смертность среди населения. Ключевые слова: борьба, наркотрафик, преступление, наркотики, международная ситуация, здоровье нации.
\end{abstract}

\section{CHARACTERISTICS OF THE DRUG SITUATION IN KYRGYZSTAN AT THE PRESENT STAGE Botobaev A.A.}

\author{
Botobaev Adilbek Aidarbekovich - colonel of militia, the chief, \\ CRIMINAL INVESTIGATION DEPARTMENT OF THE KYRGYZ REPUBLIC, \\ BISHKEK, REPUBLIC OF KYRGYZSTAN
}

\begin{abstract}
Kyrgyz Republic and the related problem of undermining the nation's health due to the global spread of drugs, the fight against drug addiction and involvement in it, all of the new people. We give expert data analyzes and evaluation of drug trafficking through Kyrgyzstan created. We study the basic directions of the state policy in relation to drug trafficking. Much attention is devoted to research on combating the spread of drug trafficking through Kyrgyzstan to other countries, in particular Russia. Statistical data and dynamics of increasing the number of drug addicts, and related other acute social problems: the spread of HIV, hepatitis $B$, a low birth rate and high death rate among the population.
\end{abstract}

Keywords: fighting, drug trafficking, crime, drugs, international situation, the health of the nation.

УДК 343

Проблема наркомании является одной из актуальных для всего мирового пространства. Практически все мировое пространство объединено в борьбе с данным антиобщественным 
явлением и сопутствующими ему процессами. Этому способствуют цифры официальной статистики: «около 32,4 миллиона человек, что составляет $0,7 \%$ взрослого населения планеты, являются потребителями лекарственных опиатов или его производных, таких как героин и опий. По некоторым данным во всем мире отмечается о 27 млн проблемных наркопотребителей, что почти соответствует численности населения такой страны, как Малайзия. Почти половина $(12,19$ млн) такого проблемного контингента наркопотребителей употребляет наркотики путем инъекций, и в их число входят около 1,65 млн человек, которые в 2013 году жили с ВИЧ» [1].

Общемировой процесс противодействия наркомании, наркотрафику и наркобизнесу. объединение всеобщих усилии привело к целому ряду глобальных процессов, направленных на противостояние и противоборство с наркоманией. Так, Генеральной Ассамблеей $\mathrm{OOH} 7$ декабря 1987 года была принята резолюция 42/112, согласно которой, 26 июня стал Международным днем борьбы со злоупотреблением наркотическими средствами и их незаконным оборотом (англ.International Day against Drug Abuse and Illicit Trafficking). Это привело к серьезной активизации мирового пространства. Так, под данной резолюцией подписалось 132 государства, которые приняли целый блок нормативных документов о совместном противодействии глобальному распространению наркотиков, борьбе с наркозависимостью и вовлечением в нее все новых людей

Кыргызстан в этом процессе занимает особое место, что, прежде всего, обосновано тем, что он находится в самом центре мирового наркотрафика. Наша страна входит в так называемый «Азиатский узел», в котором Кыргызстан играет важную роль. Согласно данным, предоставляемым УНП ООН и независимых экспертов « $40 \%$ производимых в Афганистане наркотиков проходит транзитом через Иран, 30\% через Пакистан и до $30 \%$ по «северному маршруту» через Центральную Азию на рынки России и западноевропейских государств» [2, с. 60]. Вместе с тем, данные 2016 года показывают, что «тенденцию ежегодного увеличения количества поступающих тяжелых видов наркотиков. Около 90\% наркотиков проходят транзитом через нашу республику, меньше $15 \%$ остаются в Кыргызстане» [3, с. 35]. По данным Всемирного доклада о наркотиках 2013 г., Кыргызстан занимает 10 место из 20 в списке стран наиболее часто упоминаемых в обороте героина за период с 2002 по 2012 г.

Исследованию проблем борьбы $\mathrm{c}$ наркоманией и сопутствующей ей когортой антиобщественных явлений посвящены отдельные разделы политологии, социологии, медицины, психологии, права и других. Не смотря на повышенный интерес всех областей человеческой мысли к опасности данного явления, разработки различных методологии борьбы, предупреждения и профилактики она все же имеет место быть и развиваться.

В 80-е годы XX века, сначала в практическую, а затем и в научную лексику было введено понятие «наркоситуация». В настоящее время данный термин является инструментом оперирования криминологии. Вместе с тем, данное понятие достаточно смело входит в предмет исследования и других, выше перечисленных наук.

В нашей стране, данный термин официально используется в отчетных документах правоохранительных органов, рекомендациях международных организации и пр.

Вместе с тем, считается что, не смотря на достаточно широкое оперирование данным термином, единого понятия так и не существует. Так, анализируя сложившуюся ситуацию, относительно содержания терминологии, А.М. Трофимец отмечает, что: «Между тем терминологическая точность, ясность и лаконичность имеют особое значение для правовой науки, так как ее наработки могут быть впоследствии использованы в нормотворческой деятельности и правоприменительной практике» [4, с. 59].

Ученые предлагают различные определения данного термина. Так, например, российский ученый М.Ю. Воронин под наркоситуацией понимает «... пространственно-временную характеристику ... отражающую состояние, структуру, уровень, динамику наркотизации населения Российской Федерации...». Драган Г.Н. и Калачев Б.Ф. под этим же термином понимают «состояние, структура, уровень и динамика незаконного распространения наркотиков и наркобизнеса в пределах какой-либо территории» $[5$, с. 6]. Тогда как А.Ф. Галузин отмечает, что наркоситуация - это «... состояние общества, социальных групп с точки зрения количественных и качественных характеристик проявлений наркотизма в определенном месте, времени, отражающее закономерности, тенденции, динамику наркотизма и антинаркотизма...» [6, с. 96]. То есть авторы оперируют целым спектром понятий. В описание наркоситуации как таковой вовлечены такие термины как «незаконное распространение наркотиков», «наркотизация», «антинаркотизм» и прочее. То есть, в содержание термина 
«наркоситуация» вовлечены различные негативные аспекты, связанные с наличием наркотиков на той или иной территории.

Немного иную трактовку понятия «наркоситуация» дано отечественным исследователем А. Зеличенко. Он считает, что: «Термин "наркоситуация" включает в себя два больших понятия. Первое - наркополитика, то есть отношение государства к проблеме наркотиков: от способов ее решения и до отношения чиновников и общества к наркозависимым людям. Второй момент характеристика наркорынка, а это уже количество наркозависимых, виды запрещенных веществ, цены на них, каналы распространения и прочее. Изучение этих составляющих и дает нам понятие о наркоситуации» [7. с. 24]. В данном случае возникают еще два термина, которые также не имеют четкого научного определения, но по сути своей четко объясняют ситуацию.

Следует отметить, что в настоящее время, государства и международные организации весьма активно и глубоко проводят анализ наркоситуации в том или ином регионе. Так, например, Национальный Отчет Республики Казахстан «О Наркоситуации в Республике Казахстан за 2014 год», подготовленный по инициативе Общественного Фонда «Центр мониторинга за алкоголем и наркотиками» рассмотрены такие вопросы как: наркополитика, употребление наркотиков среди населения в целом и среди конкретных целевых групп, профилактика, проблемное потребление наркотиков, лечение, взаимосвязь наркотиков и состояние здоровья, ответные действия по наркозависимости и пр. [8]. Тогда как в Обзор о наркоситуации в Республике Таджикистан содержит в себе информацию о тенденциях производства наркотических средств в регионе, о наркоситуации в регионе и противодействии наркотрафику в Таджикистане, о контроле за оборотом наркотических и психотропных средств [9]. Анализ других отчетов и докладов о наркоситуации в той или иной территориях показывает, что ответственные органы самостоятельны в выборе структуры и содержания документов. То есть, на официальном уровне также нет единого подхода.

Краткое описание наркоситуции в Кыргызстане дано в Антинаркотической Программе Правительства Кыргызской Республики от 27 января 2014 года № 54 и принимая данную программу высший исполнительный орган нашей Республики также был достаточно самостоятелен. Отдельные аспекты раскрываются в отчетах международных организации. И наличие таких отчетов позволяет привлекать мировое и общественное внимание к существующей проблеме, корректировать меры и средства правоохранительных органов и общественности.

Соответственно, считаем, что отсутствие единого подхода к содержанию понятия влечет за собой разночтения, пример которых мы привели.

На наш взгляд, термин «наркоситуация» следует трактовать как достаточно широкое понятие. Эта широта определения должна включать в себя:

1. Первопричины наличия наркомании, наркотрафика и наркобизнеса в данном регионе и способствующие этому условия. Выявление и анализ причин и условий главным образом способствует пониманию способов и средств профилактики и борьбы с этими антиобщественными явлениями.

2. Анализ состояния, структуры, уровня и динамики повышения или снижения уровня потребления и незаконного оборота наркотических средств и психотропных веществ на определенной территории основанную на характеристике вовлеченных социальных слоев, вовлекаемых в наркотизацию;

3. Исследование системы государственных и общественных мер по профилактике и борьбе с незаконным изготовлением, распространением (оборотом) и немедицинским потреблением наркотиков.

То есть, на наш взгляд, полную картину наркоситуации дает комплексный подход. И соответственно, такой разносторонний анализ позволяет точно оценивать состояние угрозы, эффективность ранее предпринятых ранее мер и соответственно разрабатывать мероприятия по эффективной борьбе с данным видом антиобщественного явления.

Следует отметить, что сложившаяся ситуация, связанная с незаконным оборотом наркотиков в некоторых рассматриваемых нами регионах напрямую связана с развитием плачевной наркоситуации в глобальном масштабе, когда наблюдается значительное повышение спроса на наркотические средства и психотропные вещества; увеличение доли «жестких» наркотиков (героин, кокаин) и наркотиков синтетического происхождения в общей массе; поиск и формирование наркогруппировками новых рынков наркотических средств и маршрутов их перевозки с вовлечением территорий новых стран; превращение транзитных государств в регионы употребления наркотиков; все большее распространение наркотиков в молодежной среде; расширение масштабов и укрепление преступной деятельности криминальных наркоструктур, совершенствование их военного и технического оснащения; рост производства наркотических средств в зонах непрекращающихся вооруженных 
конфликтов; продолжение экспансии наркотиков на территорию России и других странучастниц СНГ [10, с. 3].

Эти тенденции в полной мере отразились на состоянии наркоситуации Кыргызстана.

Анализируя современную наркоситуацию в стране, разработчики Антинаркотической программы Кыргызской Республики отметили в ней целый спектр вопросов, ставших причинами сложившегося состояния вещей (они более подробно будут рассмотрены во втором подразделе).

Как уже отмечалось, роль Кыргызстана в антинаркотическом противодействии является достаточно существенной, так как именно такие страны как Казахстан и Кыргызстан являются заслоном в поставке наркотиков в другие страны. Так, по сведениям Государственной службы по контролю наркотиков при Правительстве КР только с начала 2016 года «на территории Кыргызской Республики выявлено и ликвидировано 5 значимых канала трафика афганских наркотиков через Кыргызстан по «северному маршруту». Общий вес изъятых из незаконного оборота наркотических средств составил 48 кг 404 грамм, в том числе: героина - 3 кг 511 гр., опия - 11 гр., гашиша - 44 кг 882 гр» [11]. Тогда как за 12 месяцев 2015 года характеризуется снижением изъятия опия на 111 килограммов и увеличением изъятых героина (на 58 килограммов), гашиша (на 47 кг), кокнара (на 38 кг), марихуаны (на 447 кг), каннабиса (на 916 килограммов) и прекурсоров (на 9 тонн) [12]. И по всей видимости объем наркотрафика будет наращиваться, так как по официальным данным: «рост производства в Афганистане опия в текущем году может составить около $20 \%$ по сравнению с 2014 годом. Таким образом, объем произведенного в стране опия в этом году достигнет 8 тыс. тонн. За последние 14 лет объем производимых наркотиков вырос в 40 раз, а количество полученного опия в текущем году может достичь 8 тыс. тонн, что превысит показатели прошлого года на 20\%» [13].

Кроме того, следует помнить и о том, что Кыргызская Республика обладает собственной немалой сырьевой базой для производства гашиша и ряду других наркотических средств. Вместе с тем, считается, что через территорию Кыргызстана проходит примерно $30 \%$ афганского опия.

Вместе с тем, 10 - 15\% тяжелых наркотиков остается на территории Кыргызстана, что не может не сказаться на состоянии здоровья коренного населения. Реальная ситуация такова, что Кыргызская Республика в полной ее мере, во всех аспектах отражает влияние геополитического положения страны. По некоторым данным Республиканского центра наркологии Министерства здравоохранения Кыргызской Республики, в определенной прогрессии растет число граждан, употребляющих наркотики. Причем возрастной контингент значительно молодеет, не ограничиваясь рамками возраста, региона либо социального и семейного положения. При этом наблюдается постоянное увеличение немедицинского (т.е. инъекционного) потребления наркотиков и прежде всего - героина, что угрожает катастрофическим распространением в Кыргызстане ВИЧ-инфекции, гепатита и других болезней, имеющих сходные пути передачи. На сегодняшний день в республике официально отмечается о более, чем 9 тысяч граждан, употребляющих наркотики, $88 \%$ из них сидят на тяжелых инъекционных наркотиках (ПИН). Это потребители опия, героина. Их число выросло на $21 \%$ и это в основном мужчины от 30 до 40 лет. При этом 7,5 тысячи кыргызстанцев проживают в южном регионе страны» [14].

Исследование, проведенное согласно Программе по предотвращению распространения наркотиков в Центральной Азии (CADAP) - фаза 5 компонентом DAMOS (Сбор и разработка базы данных по наркоэпидемиологии) определило, что количество учащихся 5 - классов, пробовавших наркотики, - $0,3 \%$ от общего числа (5 человек из 15 тыс. чел.). Количество старшеклассников - 1,3\% (26 человек из 2 тыс. чел.). Доля учащихся ПТУ составила $3 \%$ или 6 человек из 200 человек. Анализ показал, что впервые попробовали наркотики дети возрастом от 10 - 14 лет [15].

Кроме того, ученые отмечают тот факт, что «наркобизнес в Кыргызской Республике становится все более закрытым и профессиональным» [16]. Это же констатируется и практиками, так в своем интервью Р. Мамбеталиев сказал, что: «Наркокоррупция в госорганах и среди сотрудников правоохранительных органов является большой проблемой, поскольку сами же сотрудники ГСКН являются распространителями наркотиков.... ОПНГ (наркогруппировки) и ОПНС (наркосообщества), из практики правоохранительных органов, сформированы по национальным, семейно-клановым признакам и землячеству. Такие преступные формирования организуют каналы поставки и транзита наркотиков на и через территорию республики для последующего их сбыта на территориях стран ближнего и дальнего зарубежья (Республики Казахстан, России, странах Европы и КНР)» [17].

Определенный обзор наркоситуации дан в целом ряде диссертационных исследований кыргызских ученых. В частности особо следует отметить работы таких отечественных ученых как: Хакимов Р.М. «Расследование преступлений, связанных с незаконным оборотом 
наркотических средств: по материалам Кыргызской Республики», Осмоналиева К.М. «Уголовно-правовые меры предупреждения и пресечения незаконного оборота наркотических средств: По материалам Кыргызской Республики», Исмаилова Р.Т. «Вовлечение несовершеннолетних в употребление наркотических средств и психотропных веществ и его предупреждение органами внутренних дел (по материалам КР и РФ)», Кыдыркулова К.К. Организация взаимодействия органов внутренних дел с институтами гражданского общества по противодействию наркотизму: по материалам Кыргызской Республики и других научных исследований по данной проблематике.

В целом все эти ученые отмечают, что наркоситуация в Кыргызстане напрямую определена мировыми тенденциями. Геополитическое расположение страны приводит к достаточно сложному положению вещей по вопросам наркотизации, развития наркотрафика и незаконного оборота наркотиков. При этом в Республике делаются серьезные шаги в области профилактики и борьбы с наркозависимостью, борьбы с незаконным наркотрафиком и деятельностью наркобизнеса. Так, Кыргызстан участник ряда международных организации задачами которого являются вопросы борьбы с наркотизмом, а именно Организации договора о коллективной безопасности (ОДКБ), Шанхайской организацией сотрудничества (ШОС), Управления ООН по наркотикам и преступности (УНП ООН), Инициативы Афганистан, Кыргызстан, Таджикистан (АКТ) и целого ряда других. Предпринимаются серьезные шаги в области совершенствования уголовного, административного и иного законодательства. В процессе профилактики и борьбы вовлекаются общественные институты и пр. То есть страна пытается оказать адекватное сопротивление существующим реалиям. Анализ эффективности такого реагирования является необходимым условием совершенствования соответствующей государственной политики, которая, на наш взгляд, представляет собой всю систему мер, разрабатываемых и реализуемых на государственном и межгосударственном уровне, обеспечивающая формирование нетерпимых взглядов гражданского населения к лицам, распространяющим наркотические вещества.

Система таких мер включает в себя комплекс мер административного, криминального, информационного, социального и иного характера. Анализ проблем и перспектив административного и информационного воздействия с целью антинаркотического воздействия на общество является основной целью представленного исследования.

\section{Список литературы / References}

1. Всемирный доклад о наркотиках за 2015 год. [Электронный ресурс]. Режим доступа: https://www.unodc.org/documents/wdr2015/WDR15_ExSum_R.pdf/ (дата обращения: 10.03.2017).

2. Информационный бюллетень о наркоситуации Центральноазиатский регион =Information bulletin on drug related situation the Central Asian region. Ташкент: Baktria press, 2013. $60 \mathrm{c}$.

3. Итоги деятельности ГСКН при Правительстве Кыргызской Республики за январь-март 2016 года. [Электронный ресурс]. Режим доступа: http://www.gskn.kg/files/narkosituatsiya2/narkosituatsiya-za-1-kvartal-2016-goda/ _дата обращения: 10.03.2017).

4. Трофимец А.М. Общая характеристика наркоситуации в мире // «Наркоконтроль», 2006. № 1. C. $59-67$

5. Драган Г.Н., Калачев Б.Ф. Наркомания и наркобизнес: выявление и пресечение незаконного оборота наркотических средств и психотропных веществ / Под ред. д.ю.н., проф. П.Г. Пономарева. М., 1998. С. 6.

6. Галузин А.Ф. О наркотизме и нарколоббизме в теории и практике обеспечения безопасности личности, общества (государства) // «Право и политика», 2007. № 11.

7. Страна наркоТрафика // Central Asia Monitor от 15 октября 2016 года.

8. Национальный Отчет Республики Казахстан. О Наркоситуации в Республике Казахстан за 2014 год. [Электронный ресурс]. Режим доступа: http://mcadkz.org/assets/files/AR_-2014Kazakhstan-V-1.3-RU.pdf/(дата обращения: 10.03.2017).

9. Информационно-публицистический ресурс «Нет наркотикам». [Электронный ресурс]. Режим доступа: http://news.tj/ru/news/akn-rt-izdal-obzor-o-narkosituatsii-v-respubliketadzhikistan-za-2008-god?quicktabs_1=3/ (дата обращения: 10.03.2017).

10. Проблемы наркобезопасности современного российского общества. Автореферат диссертации. Новгородский А.В. 
11. Итоги деятельности ГСКН при Правительстве Кыргызской Республики за январь - март 2016 года // http://www.gskn.k Н. Ганыева.

12. Наркоситуация в Кыргызстане за 2015 год характеризуется снижением изъятия опия. [Электронный ресурс]. Режим доступа: http://24.kg/obschestvo/27353_narkosituatsiya_v_kyirgyizstane_za_2015_god_harakterizuetsya_ snijeniem_izyyatiya_opiya/g/files/narkosituatsiya2/narkosituatsiya-za-1-kvartal-2016-goda/ (дата обращения: 10.03.2017).

13. Наконец-то замеченная нарковойна: Генштаб заявил о резком росте производства наркотиков в Афганистане. [Электронный ресурс]. Режим доступа: http://www.nakanune.ru/news/2015/10/8/22416873/ (дата обращения: 10.03.2017).

14. Национальная программа реформирования системы здравоохранения Кыргызской Республики «Ден соолук» на 2012-2018 годы. [Электронный ресурс]. Режим доступа: http://www.rce.kg/pravovaya-baza/nacionalnyedokumenty/nacionalnayaprogramma-den-sooluk/ (дата обращения: 10.03.2017).

15. Обзор страновой ситуации: Кыргызстан. [Электронный ресурс]. Режим доступа: http://www.emcdda.europa.eu/html.cfm/index211504RU.html/ (дата обращения: 10.03.2017).

16. Исмаилов Р.Т. «Вовлечение несовершеннолетних в употребление наркотических средств и психотропных веществ и его предупреждение органами внутренних дел (по материалам КР и РФ)». [Электронный ресурс]. Режим доступа: http://www.linguanet.ru/science/dissD/dissD1/ D1-2014/F.I.O/D1diss-NN.pdf]/ (дата обращения: 10.03.2017).

17. Рафик Мамбеталиев, председатель ГСКН КР: «Распространению наркотиков в Кыргызстане помогают сами сотрудники правоохранительных органов». [Электронный ресурс]. Режим доступа: http://kyrtag.kg/standpoint/rafik-mambetaliev-predsedatel-gskn-kr-rasprostraneniyunarkotikov-v-kyrgyzstane-pomogayut-sami-sotru/ (дата обращения: 10.03.2017). 


\title{
ИЗ ПРАКТИКИ ПРИМЕНЕНИЯ ПРОЕКТНЫХ ТЕХНОЛОГИЙ ПРИ ОРГАНИЗАЦИИ АТТЕСТАЦИИ СТУДЕНТОВ ПО ДИСЦИПЛИНЕ «ОСНОВЫ БРЕНДИНГА» Антонина Л.В. ${ }^{1}$ Юферова Л.В. ${ }^{2}$ Email: Antonina1791@ scientifictext.ru

\author{
${ }^{1}$ Антонина Людмила Владимировна - кандидат технических наук, дочент; \\ ${ }^{2}$ Юферова Лилия Васильевна - кандидат технических наук, стариий преподаватель, \\ кафедра товароведения и экспертизы качества, факультет экономики и сервисных технологий, \\ Омский государственный технический университет, \\ Институт дизайна и технологий, \\ 2. Омск
}

\begin{abstract}
Аннотация: в условиях формирования цивилизованных рыночных отночений актуальны развитие технологий брендинга и его изучение. Преподавание курса «Основы брендинга» основано на использовании специальных обучающих технологий. В статье описан пример практического использования проектных образовательных технологий при организации аттестации студентов по дисииплине «Основы брендинга». Представлен план проектного задания, общие требования и рекомендации к заданию, приведено детальное описание преимуществ реализачии проектного способа аттестачии.
\end{abstract}

Ключевые слова: брендинг, высшее образование, проектные обучающие технологии, конкурс брендов, аттестаиия.

\author{
OF PRACTICAL APPLICATION DESIGN TECHNOLOGY \\ FOR CERTIFICATION TO THE STUDENTS ON THE DISCIPLINE \\ "FUNDAMENTALS OF BRANDING" \\ Antonina L.V. ${ }^{1}$, Yuferova L.V. ${ }^{2}$ \\ ${ }^{I}$ Antonina Lyudmila Vladimirovna - candidate of technical sciences, associate professor; \\ ${ }^{2}$ Yuferova Liliya Vasilyevna - candidate of technical sciences, senior lecturer, \\ DEPARTMENT OF COMMODITY RESEARCH AND EXAMINATION OF THE QUALITY, FACULTY OF \\ ECONOMICS AND SERVICE TECHNOLOGIES, \\ OMSK STATE TECHNICAL UNIVERSITY, \\ INSTITUTE OF DESIGN AND TECHNOLOGY, \\ $O M S K$
}

\begin{abstract}
: in the conditions of forming of the civilized market relations development of branding technologies and his study are actual. Teaching the course "Fundamentals of branding" is based on the use of special teaching technologies. The article describes an example of the practical use of the design of educational technologies in the organization of assessment of students on discipline "Fundamentals of branding". Presented plan project tasks, general requirements and recommendations for the task, provides a detailed description advantages of project method of attestation.
\end{abstract}

Keywords: branding, higher education, design of educational technologies, competition of brand, attestation.

УДК 378.14

Существует целый ряд факторов усиления позиций брендинга как на мировом, так и на российском рынке. Основным - является фактор обильного насыщения рынка товарами и услугами. Жесткая конкурентная борьба на фоне роста разнообразия продукции и услуг определяет актуальность развития технологий брендинга и его изучения в рамках высшего образования. Современная модель управления организацией или производством предполагает обязательное использование теории и практики брендинга.

Брендинг - деятельность по созданию долгосрочного предпочтения потребителя к товару или услуге, нацеленная на формирование потребительской привычки покупать товар или пользоваться услугой [1, с. 17]. 
Дисциплина «Основы брендинга» в ряду экономических, управленческих и финансовых дисциплин, использующих маркетинговые принципы, является одним из основополагающих теоретических и методических фундаментов для формирования у студентов управленческого мышления, основанного на понимании сущности и применения технологий брендинга в различных сферах бизнеса в эпоху глобализации [2, с. 6].

Процесс изучения дисциплины «Основы брендинга» направлен на освоение студентами теоретических и практических основ брендинга.

Целью курса «Основы брендинга» является формирование у студентов четкого представления о сути бренда и брендинга, как максимально эффективном способе продвижения и реализации товаров и услуг. Основными задачами дисциплины являются определение роли брендинга в формировании цивилизованных рыночных отношений, введение основного понятийного и концептуального аппарата, изучение структуры бренда, особенностей его построения и организации, изучение основ управления - принципов эффективного брендинга.

Преподавание курса «Основы брендинга» основано на применении специфических педагогических форм с использованием инновационных обучающих технологий. Курс должен быть построен на методах активного обучения [3, с. 13-15] с целью погружения студента в практикориентированную учебную активность, в аналитическую деятельность и в деятельность по имитации проектных и управленческих решений в сфере брендинга.

Проектная технология организации итоговой аттестации по дисциплине позволяет соответствовать заявленному образовательному подходу. Апробация такой технологии была проведена при аттестации студентов ОмГТУ ИДиТ, обучающихся по направлению подготовки «Торговое дело» направленности (профиля) «Коммерция».

Дисциплина «Основы брендинга» входит в вариативную часть профессионального цикла Федерального государственного образовательного стандарта высшего образования (ФГОС ВО) для бакалавров, обучающихся по направлению «Торговое дело» [4]. Изучение курса «Основы брендинга» в совокупности с дисциплинами «Основы маркетинга», «Теория рекламы», «Основы интегрированных коммуникаций», входящими в вариативную часть профессионального цикла ФГОС ВО, обеспечивает формирование профессиональных компетенций бакалавра, связанных с готовностью к выявлению и удовлетворению потребностей покупателей товаров, их формированию с помощью маркетинговых коммуникаций, способностью изучать и прогнозировать спрос потребителей, анализировать маркетинговую информацию, конъюнктуру товарного рынка. Плановой процедурой итогового контроля по дисциплине «Основы брендинга» в 5 семестре является зачёт.

Для получения зачёта на заключительном этапе изучения дисциплины студентам был предложен альтернативный вариант аттестации. Заданием являлось формирование и представление собственного проекта разработки бренда по следующему плану:

1. Характеристика субъекта предполагаемой деятельности (описание производителя продукта или услуги);

2. Характеристика объекта предполагаемой деятельности (описание проектируемого продукта или услуги);

3. Краткая аналитика посредством конъюнктурного, конкурентного и сегментационного анализа, результатом которого является сформированный «портрет потребителя»;

4. Формирование пирамиды бренда с указанием рациональных и эмоциональных конкурентных преимуществ, атрибутов, характера бренда, «личности» бренда, его сути;

5. Определение платформы бренда с указанием миссии, ценностей, видения;

6. Позиционирование бренда в системе: продукт - имидж - цена;

7. Разработка элементов вербальной идентификации бренда (наименование, слоган, легенда, метафора и пр.);

8. Разработка элементов визуальной идентификации бренда (логотип, цвет, шрифт, графика, образ и пр.);

9. Планирование бренд - коммуникаций с указанием каналов распространения информации;

10. Планирование мероприятий по расширению (растяжению) бренда.

Теоретическая составляющая пунктов соответствует лекционному содержанию дисциплины, структурированному в три основных укрупненных модуля:

1. Введение в брендинг (понятия, концепции, эволюция брендинга);

2. Брендинг как процесс (подготовка, проектирование и реализация);

3. Эффективный бренд - менеджмент (управление мероприятиями по поддержанию и развитию бренда). 
К общим требованиям и рекомендациям относились актуальность проекта, обязательное сопровождение проекта презентационным материалом (не менее 10 слайдов), а также творческий подход.

В перечень ресурсов для формирования проекта входили литературные и интернетисточники, которые использовались в процессе изучения дисциплины «Основы брендинга».

Выполнение проекта происходило за счет времени, отводимого на самостоятельную работу студента.

Результатом организации такого способа аттестации явился «Конкурс брендов», который проводился в часы практического занятия в последнюю неделю семестра. Оценивание проектов проводилось каждым из участников конкурса и присутствующими путем заполнения «Оценочного листа проекта по разработке бренда». Критериями оценки явились: актуальность темы проекта, уровень аналитической составляющей, уровень творческого подхода, качество доклада и презентационного материала.

Для проведения оценки использовалась балльная шкала, соответствующая балльно рейтинговой системе контроля и оценки результатов учебной деятельности студентов ОмГТУ ИДиТ. На основе набранных баллов определялось место студента в «Конкурсе брендов» и итоговая оценка результатов по дисциплине «Основы брендинга».

В качестве субъектов деятельности студенты выбирали различные предприятия: торговое предприятие «Игр/ОК. Игры для больших детей и маленьких взрослых» (студент Петряков Артём), предприятие по производству и реализации фарфоровой посуды «Приятного аппетита!» (студентка Козлова Алина), предприятие по производству и реализации безалкогольных коктейлей на основе натуральных ингредиентов «Dеер» (студентка Дунёва Анна), а также предприятия по организации сервиса и услуг: агентство праздников «Фейерверк радостей» (студентка Арзуманян Нарине), база отдыха «Мороз и солнце» (студентка Волкова Анна) и др. Аналитическая часть проекта послужила обоснованием для проектирования брендов. В качестве инструмента описания и визуализации содержания бренда использовалась пирамиды, отражающая личность, ценности, характер, суть проектируемого бренда. Сформированная пирамида бренда явилась основой для разработки элементов вербальной и визуальной идентификации задуманных брендов. Также студентам удалось сформировать перспективный план бренд - коммуникаций, направленный на выведение на рынок новой продукции (услуги), учитывающий перспективные подходы и инновации в области брендинга.

Теоретическая и практическая подготовка студентов по дисциплине, осуществляемая на лекционных и практических занятиях, позволила осуществить самостоятельное проектирование. Студенты с энтузиазмом отнеслись к разработке своего собственного бренда. Опрос студентов, участвующих в проектировании, показал, что $100 \%$ согласны с такой формой подведения итогов по дисциплине «Основы брендинга»; $60 \%$ - видят проект составной частью своей будущей выпускной квалификационной работы.

С целью детального описания преимуществ использования проектной технологии, рассмотрим задачи, решаемые при реализации проектного способа аттестации по дисциплине «Основы брендинга»:

- реализация имитационных поисковых методов обучения, основанных на моделировании производственного процесса брендинга;

- проявление теоретических знаний в процессе исследования, аналитики и проектирования;

- определение структурных связей между теоретическими знаниями по профессиональным дисциплинам и практическими умениями;

- формирование у студентов проективных умений;

- обобщение и структурирование полученных знаний путем формирования целостного проекта;

- формирование опыта творческой деятельности, развитие креативности;

- продуктивность периода, отводимого на самостоятельную работу студента;

- саморазвитие и самообразование студента посредством анализа теоретического содержания дисциплины, решения профессиональных задач;

- создание положительного мотивационного настроя на обучение и на аттестацию;

- создание среды образовательного общения, которое характеризуется возможностью взаимной оценки и контроля.

Таким образом, данный практический опыт служит примером внедрения современных проектных технологий в образовательный процесс, который может быть использован при организации учебного курса по дисциплине «Основы брендинга». 
1. Брендинг: учебник для бакалавров/ И.Я. Рожков, В.Г. Кисмерешкин. М.: Издательство Юрайт, 2013. 331 с. Серия: Бакалавр. Углубленный курс. С. 17.

2. Брендинг: учебник для бакалавров/ А.М. Чернышева, Т.Н. Якубова. Издательство Юрайт, 2014. 504 с. Серия: Бакалавр. Базовый курс. С. 6.

3. Лаврентьев Г.В., Лаврентьева Н.Б., Неудахина Н.А. Инновационные обучающие технологии в профессиональной подготовке специалистов. Барнаул: Изд-во Алт. ун-та, 2004. C. 13-15.

4. Федеральный государственный стандарт высшего образования (Приказ Минобрнауки Российской Федерации № 1334 от 12 декабря 2015). [Электронный ресурс]. Режим доступа: http: //www.fgosvo.ru/ (дата обращения: 20.02.2017).

\title{
ЦЕННОСТНО-СМЫСЛОВЫЕ ОРИЕНТИРЫ КАК ФАКТОР МОТИВАЦИИ В ДОПОЛНИТЕЛЬНОМ ОБРАЗОВАНИИ Дащенко C.H.Email: Dashchenko1791@ scientifictext.ru
}

\author{
Дащенко Светлана Николаевна - магистрант, \\ кафедра дизайна и методики профессионального обучения, \\ Чувашский государственный педагогический университет им. И.Я. Яковлева, \\ 2. Чебоксары
}

\begin{abstract}
Аннотация: в статье анализируются ценностно-смысловые ориентиры дополнительного образования как фактор мотивачии обучающихся. Проблема мотивации обучающихся к дополнительному образованию достаточно значима, поэтому ченностно-смысловые ориентиры в данной статье представлены как специфический, нетривиальный фактор мотивачии. Современная система образования ставит перед педагогами задачу формирования ученика как гармоничной, всесторонне развитой личности. Сам ученик мысллится не как «формируемый объект», а как полноиенный субъект, который выступает в качестве партнера педагога. Ввиду этого иенностно-смысловые ориентиры дополнительного образования представлены в данной статье в качестве ориентиров совместной деятельности педагога и ученика.
\end{abstract}

Ключевые слова: дополнительное образование, иенностно-смысловые ориентиры, мотивация, обучение.

\section{VALUE AND SENSE OBJECTIVES (OF LEARNING) AS A FACTOR FOR MOTIVATION IN ADDITIONAL EDUCATION Dashchenko S.N.}

\author{
Dashchenko Svetlana Nikolaevna - master, \\ DEPARTMENT OF DESIGN AND METHODS OF TRAINING, \\ CHUVASH STATE PEDAGOGICAL UNIVERSITY NAMED AFTER IVAN YAKOVLEVICH YAKOVLEV, \\ CHEBOKSARY
}

\begin{abstract}
: the article analyzes value and sense objectives (of learning) as a factor for motivation in additional education. The problem of motivation of students to secondary education rather significant, therefore of value and meaning in this article are presented as specific, non-trivial motivating factor. The modern system of the federal state educational standards (GEF) has set the task of forming the student teachers as a harmonious, comprehensively developed person. Himself a pupil at the same time, conceived, not as an "object formed," but as a complete entity that acts as a partner of the teacher. In this vein, the value-semantic orientations of additional education serve as benchmarks of joint activities of the teacher and student.
\end{abstract}

Keywords: value and sense objectives, learning, additional education, motivation.

УДК 37.026 .6

Проблема мотивации обучающихся к дополнительному образованию на современном этапе является достаточно значимой, что обусловлено невозможностью общеобразовательной школы обеспечить все познавательные потребности обучающихся, в частности, потребность в 
расширении кругозора. Среди средств формирования мотивации учащихся к дополнительному образованию (как к конкретному учебному курсу, так и в целом формирование потребности к расширению своих знаний и умений), выделяются ценностно-смысловые ориентиры дополнительного образования, которые, зачастую, могут быть недооценены педагогами в качестве мотивационного механизма [5, с. 76].

Современная система федеральных государственных образовательных стандартов (ФГОС) ставит перед педагогами задачу формирования ученика, как гармоничной, всесторонне развитой личности. Сам ученик при этом мыслится не как «формируемый объект», а как полноценный субъект, который выступает в качестве партнера педагога. В данном ключе ценностно-смысловые ориентиры дополнительного образования выступают в качестве ориентиров совместной деятельности педагога и ученика [4, с. 32].

В качестве основных ценностно-смысловых ориентиров дополнительного образования, которые могут выступать в качестве факторов мотивации к обучению, можно назвать следующие:

1. Ответственное отношение к будущей профессии (в случае «профориентированного» дополнительного образования).

2. Понимание ценности творчества как человеческой деятельности, стремления самостоятельно осуществлять творческую деятельность.

3. Понимание ценности обширного кругозора и эрудиции.

4. Стремление расширить собственную эрудицию.

5. Понимание ценности социализации и коммуникации, стремление расширить собственные коммуникативные навыки, в том числе, в условиях неформального общения в условиях занятий дополнительного образования.

6. Понимание необходимости формирования универсальных учебных действий (УУД) не только в рамках общеобразовательной школы, но и дополнительно - в иных видах деятельности, которые предлагает дополнительное образование.

Перечисленные ценностно-смысловые ориентиры могут выступать в качестве мотивационных механизмов в случае, если они не просто «декларированы» педагогом, но и осознанны и приняты учеником, ввиду чего необходимо организовать особые условия общения в условиях учебного занятия.

Организация таких условий может быть реализована при использовании специальных видов деятельности и образовательных технологий. В первую очередь, это учебно-исследовательская деятельность, проектная деятельность, проблемное обучение.

На современном этапе проектная деятельность является одним из ведущих методов работы в педагогике, что обусловлено новой концепцией образования, на основе системно-деятельностного подхода, по которому разработаны требования ФГОС. Проектная деятельность позволяет создать условия взаимодействия педагога и учеников в условиях занятия в дополнительном образовании, при которых возникает общая цель (цель проекта), планирование достижения данной цели, совместная реализация плана, получение результата [3, с. 31].

Ценностно-смысловые ориентиры в случае проектной деятельности предполагают стремление к достижению цели, стремление к плодотворному сотрудничеству и коммуникации с педагогом и соучениками, а также совместную рефлексию и оценку результатов своей деятельности. При этом, каждый этап проектной деятельности: постановка цели, планирование, реализация, оценка результатов и рефлексия сопровождается установление «промежуточных» ценностно-смысловых ориентиров, характерных именно для данного этапа, что, во многом, обуславливает такой эффект проектной деятельности, как самомотивируемость [2, с. 54]. Исходя из этого, можно говорить о том, что проектная деятельность не нуждается в дополнительных механизмах мотивации именно благодаря системе ценностно-смысловых ориентиров на каждом ее этапе. Ценностно-смысловые ориентиры при этом, опосредуют общение педагога и учеников, что в значительной степени способствует развитию коммуникационных навыков.

Особого внимания заслуживает также и учебно-исследовательская деятельность - как особая технология обучения, предполагающая реализацию этапов деятельности, сходных по структуре и смыслу с этапами научного исследования. Учебно-исследовательская деятельность, благодаря своей специфике способствует становлению такого ценностно-смыслового ориентира, как понимание необходимости формирования дополнительных УУД. Это осуществляется при реализации специфических этапов учебно-исследовательской деятельности (этапы обоснования актуальности исследования, постановки цели и задач, определение этапов исследования, формирование результатов и выводов по ним), на каждом из которых также возникают новые ценностные ориентиры [1, с. 35]. 
Для того чтобы ученик мог реализовать каждый из этапов учебно-исследовательской деятельности, ему необходимо приобрести качественно иные навыки и умения, научиться производить новые УУД, и именно их приобретение выступает основным ценностносмысловым ориентиром, мотивирующим обучающихся на обучение, стимулирующим их познавательный интерес.

Говоря о проблемном обучении, в основе которого лежит какая-либо избранная проблема, требующая решения, то в данном случае также существует необходимость формирования УУД, как и в случае учебно-исследовательской деятельности. Кроме того, само проблемное обучение подразумевает в основе ценностно-смысловой ориентир - решение поставленной проблемы, в особенности, если эта проблема имеет социальную значимость.

Помимо специализированных видов деятельности в условиях дополнительного образования, которые позволяют создать условия не только для формирования ценностносмысловых ориентиров, но и для становления этих ориентиров, как основы мотивации, следует отметить необходимость применения особых методов обучения. В первую очередь, это активные и интерактивные методы обучения [2, с. 45].

Активные и интерактивные методы обучения предполагают свободное взаимодействие и коммуникацию обучающегося с образовательном процессе с педагогом. В рамках анализа педагогического опыта и педагогической практики выявлено, что наиболее перспективными средствами активного и интерактивного обучения являются [1, с. 23]:

- Групповая работа, а также, работа в парах с применением средств самоконтроля и взаимоконтроля;

- Дидактические игры, что в особенности актуально для обучающихся начальной ступени образования;

- Исследовательская и экспериментальная деятельность (опыты, наблюдения);

- Средства повышения наглядности (схемы, фотографии, фильмы, рисунки и т.д.);

- Системы самоконтроля и взаимоконтроля.

Также следует отметить эффективность таких средств в рамках организации активного и интерактивного обучения, как ИКТ, в частности, презентации, анимационные схемы, фильмы, которые позволяют заострить внимание детей на наиболее «острых вопросах», что достаточно важно в рамках становления ценностно-смысловых ориентиров. В соответствии с требованием времени, учитывая огромный интерес учащихся к компьютерным технологиям, используются информационные технологии для проведения уроков и внеклассных мероприятий [1, с. 34]. Преимущества проведения уроков с применением информационных технологий следующие:

- организация занятия более четкая, темп занятия высокий, и потому больше времени можно уделить отработке навыков;

- можно использовать большое количество иллюстративного и звукового материала;

- изменяется роль учащихся, они становятся активными участниками учебного процесса;

- легче контролировать работу класса, так как деятельность ученика тут же находит свое отражение на экране компьютера;

- формируется конструктивно-критическое мышление;

- организован контроль знаний, умений и навыков.

Подводя итог вышесказанному, следует отметить, что система ценностно-смысловых ориентиров в том или ином виде деятельности, которые могут быть реализованы в системе дополнительного образования, позволяет в значительной степени повысить познавательный интерес обучающихся к деятельности и следовательно сформировать мотивацию к обучению.

\section{Список литературы / References}

1. Полат Е.С., Бухаркина М.Ю., Моисеева М.В., Петрова А.Е. Новые педагогические и информационные технологии в системе образования. М., 2014.

2. Сибирская М.П. Педагогические технологии: теоретические основы и проектирование. СПБ., 2016.

3. Цызанова Е.Н. Образовательные стандарты второго поколения. Беседа с А.М. Кондаковым // Справочник руководителя образовательного учреждения. № 1, 2012.

4. Argyris C. Teaching smart people how to learn // Harvard Business Revue, 1991. May-June.

5. Bierema L.L. Systems Thinking: A new Lens for Old Problems // Journal of Continuing Education in the Health Professions, 2003. Vol. 23. 


\title{
КОММУНИКАТИВНАЯ КОМПЕТЕНЦИЯ КАК ДЕЙСТВЕННЫЙ ФАКТОР ПРОФЕССИОНАЛЬНОГО САМООПРЕДЕЛЕНИЯ Жукова В.И. ${ }^{1}$, Федоров А.С. ${ }^{2}$ Email: Zhukova1791@scientifictext.ru
}

\author{
${ }^{\prime}$ Жукова Валерия Игоревна - студент, \\ Институт педагогики, психологии и сочиологии; \\ ${ }^{2}$ Федоров Артем Сергеевич - студент, \\ Институт иветных металлов и материаловедения, \\ Сибирский федеральный университет, г. Красноярск
}

\begin{abstract}
Аннотация: на сегодняшний день государство и общество требуют конкурентоспособности каждого индивида в сочиуме, которая проявляется через сочиильные качества: владение навыками общения, умение выстраивать диалог и др. Любые качества индивида, затрагивающие разные стороны развития личности, являются путеводными на ступени самоопределения, именно поэтому у каждого есть собственное мнение по поводу той или иной профессии. В статье рассмотрено влияние социального аспекта развития личности, а именно сформированности коммуникативной компетенции, на выбор будущего карьерного пути.

Ключевые слова: коммуникативная компетенция, профессиональное самоопределение.
\end{abstract}

\section{COMMUNICATIVE COMPETENCE, AS AN IMPORTANT FACTOR OF PROFESSIONAL SELF-DETERMINATION Zhukova V.I. ${ }^{1}$, Fedorov A.S. ${ }^{2}$}

\author{
${ }^{I} Z$ hukova Valeria Igorevna - student, \\ INSTITUTE OF PEDAGOGY, PSYCHOLOGY AND SOCIOLOGY; \\ ${ }^{2}$ Fedorov Artem Sergeevich - student, \\ INSTITUTE OF NONFERROUS METALLS AND MATERIAL SCIENCE, \\ SIBERIAN FEDERAL UNIVERSITY, KRASNOYARSK
}

\begin{abstract}
: to date, the state and society require the competitiveness of each individual in society, which is manifested through social skills: possession of communication skills, the ability to build a dialogue and $O E$ quality Any individual, affecting various aspects of the development of the individual are guiding in the degree of self-determination, which is why everyone has own opinion about a particular profession. The article considers the influence of the social aspect of personal development, namely the formation of the communicative competence, the choice of a future career path.
\end{abstract}

Keywords: communicative competence, professional identity.

УДК 378.4

В настоящее время в России ощущается дефицит квалифицированных конкурентоспособных кадров, в связи с этим главной и основной функцией любого образовательного учреждения является подготовка конкурентоспособного специалистапрофессионала. Однако чтобы стать профессионалом в своей отрасли, личность еще на ступени выбора профессии должна четко определять свое отношения к профессионально-трудовой среде конкретной деятельности, а также способ ее самореализации.

На сегодняшний день требования к профессиональным и личностным качествам индивида подверглись серьезным изменениям. В первую очередь это продиктовано массовыми изменениями в социально-политической, хозяйственно-экономической и культурной жизни общества, изменением общественного сознания.

Очевидно, что для решения процессов, в корне меняющих социокультурную действительность, необходим новый взгляд на них. В связи с этим общество испытывает потребность в компетентностной личности, способной к самостоятельному решению нестандартных проблем, активно реализующую в профессии способ интеграции общечеловеческих и личностно значимых профессиональных ценностей.

Развиваясь в рамках течения современных тенденций, выпускник нашего времени должен, прежде всего, стать активным субъектом профессионального развития. Исследование данного подхода рассматриваются в работах российских и зарубежных ученых, таких как Э. Эриксон, Е.А. Климов, И.С. Кон и др., которые посвятили свои труды вопросу становления профессионального самоопределения у индивида. 
Сегодня современное общество с большим энтузиазмом требует социально подкованных граждан, владеющих совокупностью компетенций, которые могут способствовать развитию способности к общению, ведению дискуссий, восприятию критики, саморегуляции и самоанализу проделанной деятельности. Bce названные требования, позволяющей развивающейся личности реализовать свои потребности в социальном признании и определяющей успешность процесса социализации, учитывает и прорабатывает коммуникативная компетентность.

Главное направление подготовки будущего профессионала - становление профессионального самоопределения личности, его готовность к взаимодействию с социумом.

Проблема профессионального самоопределения включает в себя множество аспектов, таких как жизненная позиция, личностные интересы, возрастная группа и др. В исследованиях А.В. Макарчука и Э.Ф. Зеера профессиональное самоопределение рассматривается как неотъемлемая составляющая профессиональной компетентности выпускника. Мы придерживаемся мнения И.Е. Сазонова, который утверждает, что профессиональное самоопределение - «это специфический этап социализации, интегрирующий субъективное отношение человека к профессиональному будущему и объективную реализованность планов в условиях доступной трудовой деятельности». К тому же многие ученые придерживаются данного определения. В плане выявления содержания профессионального самоопределения нас заинтересовало видение А.В. Макарчука, который выделяет социальный и профессиональный компоненты, заостряя внимание на том, что они не механически сливаются, образуя профессиональное самоопределение, а являются интегративным выражением определенных частей их содержания. Интегративность прослеживается и в группах компонентов профессионального самоопределения, включающих в себя качества будущего специалиста-профессионала, формирование которых актуально в настоящее время и способствуют в целом профессиональному и личностному росту индивида. Так, например, А.К. Маркова, О.В. Падалко, Н.А. Цветкова и др. выделяют следующее компоненты профессионального самоопределения:

- индивидуальность (физические качества, индивидуально-типологические особенности, качества личности и т.д.);

— мотивационно-ценностная группа (мотивы профессиональной деятельности, ценностные и нравственные ориентации);

- внешняя и внутренняя деятельность (рефлексивные действия по оценке собственных способностей, возможностей и личностных черт, принятие решений и конкретные действия по их осуществлению);

— прогностическая деятельность (цели, планы, отношение к престижу профессии);

- социальная включенность (знание требований общества, умение анализировать социально-экономическую сторону профессии, ее престижность и востребованность и т.д.) [1].

Анализируя вышеописанное можно заметить, что первый и третий компонент являются смежными с компонентами коммуникативной компетенции, такими как способность к саморегуляции и самоанализу, восприятие критики и др. Указанный факт подтверждает ее право на профессиональное самоопределение.

Под коммуникативной компетенцией будем понимать демонстрируемую область успешной коммуникативной деятельности на основе усвоенных средств и стратегий речевого общения, подкрепляемые языковыми навыками и речевыми умениями, именно так трактовал данное понятие Р.П. Мильруд [3].

Е.М. Кузьмина в структурном плане выделяет следующие компоненты коммуникативной компетенции:

— теоретический блок - знания в области межличностного взаимодействия;

- практический блок - коммуникативные умения;

— личностный блок - коммуникативные свойства и качества личности, необходимые для установления межличностного взаимодействия [2].

Однако А.В. Хуторской, давая определение понятию коммуникативной компетенции, включает в нее знание необходимых языков и способов взаимодействия с окружающими людьми и событиями, навыки работы в группе, владение различными социальными ролями в коллективе [4].

С целью подтверждения актуальности темы исследования, нами был проведен констатирующий эксперимент по исследованию уровня сформированности коммуникативной компетенции, и уровня готовности к профессиональному самоопределению. Респондентами 
эксперимента выступали студенты ФГАОУ ВО «Сибирский федеральный университет», направления подготовки 44.03.04 «Профессиональное обучение (информатика, вычислительная техника)» В исследовании приняли участие 42 студента, возраст опрошенных 17 - 19 лет. Анализ результатов эксперимента подтвердил актуальность темы исследования, поскольку $35 \%$ исследуемых показали высокий суммарный уровень сформированности коммуникативной компетенции и готовности к профессиональному самоопределению, $23 \%$ показали средний уровень и $42 \%$ показали низкий уровень. Полученная статистика говорит о необходимости разработки методического обеспечения, направленного на формирование коммуникативной компетенции и профессионального самоопределения, что будет являться следующим шагом дальнейшего исследования.

\section{Список литературы / References}

1. Научно-методический электронный журнал «Концепт». № 10. [Электронный ресурс]. Режим доступа: http://e-koncept.ru/2014/14276.htm./ (дата обращения: 13.02.17).

2. Open Library - открытая библиотека учебной информации. [Электронный ресурс]. Режим доступа: http://oplib.ru/random/view/284340/ (дата обращения: 14.02.17).

3. Мильруд Р.П. Альтернативное тестирование коммуникативной компетенции учащихся / Мильруд, Р.П. М.: АВС, 2010. 4 - 12 с.

4. Хуторской А.В. Ключевые компетенции как компонент личностно-ориентированной парадигмы образования / А.В. Хуторской. М.: Народное образование, 2012. 58. 64 с. 


\title{
КЛИНИЧЕСКИЙ УСПЕХ ЛЕЧЕНИЯ ТРУБНО-ПЕРИТОНЕАЛЬНОЙ ФОРМЫ БЕСПЛОДИЯ У ЖЕНЩИН РЕПРОДУКТИВНОГО ВОЗРАСТА ЛАПАРОСКОПИЧЕСКИМ ДОСТУПОМ Керменбаева А.Ж. Email: Kermenbaeva1791@scientifictext.ru
}

\author{
Керменбаева Айгуль Жарбановна - заведующая отделением, \\ Отделение оперативной гинекологии и ювенологии, \\ Кыргызский научный центр репродукции человека, г. Биикек, Кыргызская Республика
}

\begin{abstract}
Аннотация: в работе представлены данные клинического успеха лечения трубноперитонеальной формы бесплодия у женщин репродуктивного возраста лапароскопическим доступом, заключающегося в купировании болевого синдрома, восстановлении проходимости маточных труб, отсутствии рецидивов заболевания, наступлении маточной беременности. Материалом для работы явилось обследование и лечение 103 женщин репродуктивного возраста, подразделенных на 4 группь в зависимости от степени спаечного прочесса в малом тазу. Лапароскопический доступ в основном связан $c$ проведением операчии сальпингоовариоадгезиолизиса в сочетании с сальпингостомией. Показано, что успех лечения при I степени спаечного процесса составил в среднем 83,9\% и, соответственно, при II степени - 75,3\%, при III степени - 52,1\% и при IV степени - 21,8\%.
\end{abstract}

Ключевые слова: трубно-перитонеальная форма бесплодия, спаечный процесс в малом тазу, лапароскопия, клинический успех лечения.

\section{THE CLINICAL SUCCESS OF TREATMENT TUBE-PERITONEAL FORMS OF INFERTILITY IN WOMEN OF REPRODUCTIVE AGE LAPAROSCOPIC ACCESS} Kermenbaeva A.J.

\author{
Kermenbaeva Aigul Jarbanovna - head, \\ DEPARTMENT OPERATIVE GYNECOLOGY AND JUVENILE COUNSELLORS, \\ KYRGYZ SCIENTIFIC CENTER OF HUMAN REPRODUCTION, BISHKEK. REPUBLIC OF KYRGYZSTAN
}

\begin{abstract}
: this article is devoted the data of the clinical success of the treatment of tube-peritoneal form of infertility in women of reproductive age through laparoscopy access, consisting in relieving pain, restoring of permeability of the uterus tubes, the absence of relapse of the disease, the onset of uterine pregnancy. The material for work is medical examination and treatment was 103 women of reproductive age, divided into 4 groups depending on the degree of adhesions process in the small pelvis. Laparoscopic access connected with the conduct operation of salpingoovarioadgezioliz in conjunction with salpingostomy. It is shown that the success of treatment with I degree of adhesions process has averaged $83.9 \%$ and, respectively, the II degree - $75.3 \%$, with the III degree $-52.1 \%$ and IV degree - $21.8 \%$.
\end{abstract}

Keywords: tube-peritoneal form of infertility, adhesive process in the small pelvis, laparoscopy, the clinical success of the treatment.

УДК: $618.14+618.11-089.87: 616.90$

\section{Введение}

Лечение трубно-перитонеального бесплодия (ТПБ) в основном связано с оперативным вмешательством. Применение консервативных методов лечения ТПБ в основном используется при обнаружении инфекций, передаваемых половым путем, и направлено на элиминацию возбудителей, вызвавших воспалительный процесс органов малого таза [5]. Лапароскопия первоначально применялась лишь с диагностической целью. С появлением в арсенале современного оборудования и инструментов, таких как, волоконная оптика, ксеноновые источники света, эндовидеокамеры, лапароскопический доступ стал все более широко применяться для хирургического лечения на органах малого таза, а при лечении трубноперитонеальной формы бесплодия (ТПФБ) у женщин как основной метод $[3,9,10,1,15,17]$. 
Неоспоримые преимущества эндоскопической хирургии (меньшая инвазивность, травматичность, минимальное спайкообразование, более быстрое восстановление трудоспособности, косметический эффект и др.) делают лапароскопический метод лечения ТПФБ самым привлекательным $[6,12,11,16]$. В настоящее время производятся следующие виды лапароскопических операций при ТПФБ: сальпингоовариолизис, фимбриолизис, сальпингостомия и сальпингонеостомия $[7,8,18,20]$. По данным некоторых авторов после операции сальпингостомии частота наступления беременности составляла 15-30\%, неосальпингостомии - 7-9\%, сальпингоовариолизиса - до 50\%, фимбриопластики - 20-30\% [2, 9, 14].

Другой важной проблемой является определение эффективности лапароскопического лечения ТПФБ, прогнозирование репродуктивного исхода, коррекция и выбор способа вмешательства [1, 13]. Наличие противоречивых данных по эффективности лапароскопического лечения ТПФБ обусловило необходимость данного исследования.

\section{Материал и методы исследования}

Объектом исследования явились 103 женщины репродуктивного возраста с верифицированным диагнозом ТПФБ на основании клинических данных, ультразвукового исследования органов малого таза, гистеросальпингографии, диагностической лапароскопии. Лапароскопия проводилась на аппарате фирмы "Richard Wolf Kaze Stors - Enoloscope" (Германия) и монитора фирмы "Panasonic" (Япония). Распространенность и выраженность спаечного процесса оценивали по классификации Hulka (1998, 548 р.). По степени спаечного процесса женщины подразделены на 4 группы: 28 женщин - с ТПФБ и І степенью спаечного процесса (I группа); 44 женщины - с ТПФБ и II степенью спаечного процесса (II группа); 23 женщины - с ТПФБ и III степенью спаечного процесса (III группа); 8 женщин - с ТПФБ и IV степенью спаечного процесса в малом тазу (IV группа). Статистические данные представлены в абсолютных и процентных значениях.

\section{Результаты}

Средний возраст женщин составил $33,1 \pm 4,6$ года. Основной жалобой пациенток было отсутствие беременности, причем первичное бесплодие - 67,9\% (70 женщин) преобладало над вторичным - 31,7\% (33 женщины). В качестве оперативного лечения женщин применялась лапароскопия, а другие методы хирургического вмешательства не применялись. На рисунке 1 представлены данные об использованных видах лапароскопического вмешательства у женщин, из которого видно, что в количественном отношении преобладал сальпингоовариоадгезиолизис в сочетании с сальпингостомией - 54 женщины $(52,1 \%)$, сальпингоовариолизис в сочетании с сальпингостомией - 24 женщины $(23,2 \%)$, сальпингостомия - 22 женщины $(21,3 \%)$ и сальпингоовариолизис - 3 женщины $(3,2 \%)$.

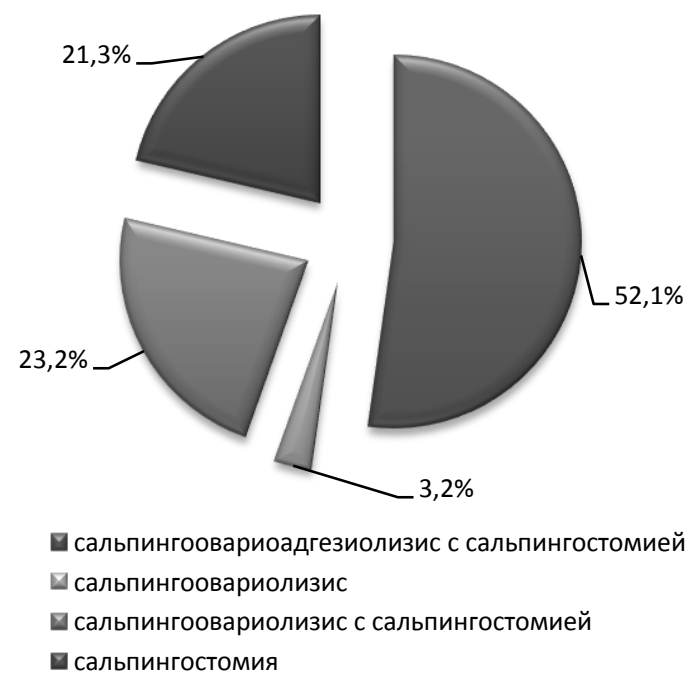

Рис. 1. Вид лапароскопической операџии у женщиин с ТПФБ 
Вид лапароскопического вмешательства в группах имел отличительные черты (таблица 1). Так, в I группе 14 женщинам (50\%) проведена сальпингостомия, у 11 женщин (39,3\%) сальпингоовариолизис в сочетании с сальпингостомией, у 3 женщин $(10,7 \%)$ сальпингоовариолизис. Во II группе основным методом лапароскопии являлся сальпингоовариоадгезиолизис с сальпингостомией -23 женщины $(52,2 \%)$, сальпингоовариолизис с сальпингостомией - 13 женщин $(29,5 \%)$ и сальпингостомия - 8 женщин $(18,2 \%)$. У женщин III и IV группы производился только сальпингоовариоадгезиолизис с сальпингостомией - $23(100 \%)$ и $8(100 \%)$ женщин соответственно.

Таблица 1. Количественные показатели методов лапароскопического вмешательства у женщин с ТПФБ

\begin{tabular}{|c|c|c|c|c|c|c|c|c|}
\hline \multirow{3}{*}{$\begin{array}{c}\text { Вид лапароскопической } \\
\text { операции }\end{array}$} & \multicolumn{8}{|c|}{ Группы женщин } \\
\hline & \multicolumn{2}{|c|}{ I } & \multicolumn{2}{|c|}{ II } & \multicolumn{2}{|c|}{ III } & \multicolumn{2}{|c|}{ IV } \\
\hline & Абс. & $\%$ & Абс. & $\%$ & Абс. & $\%$ & Абс. & $\%$ \\
\hline $\begin{array}{c}\text { Сальпингоовариоадгезиоли } \\
\text { зис с сальпингостомией }\end{array}$ & - & - & 23 & 52,2 & 23 & 100 & 8 & 100 \\
\hline $\begin{array}{c}\text { Сальпингоовариолизис с } \\
\text { сальпингостомией }\end{array}$ & 11 & 39,3 & 13 & 29,5 & - & - & - & - \\
\hline Сальпингостомия & 14 & 50 & 8 & 18,2 & - & - & - & - \\
\hline Сальпингоовариолизис & 3 & 10,7 & - & - & - & - & - & - \\
\hline
\end{tabular}

Наиболее объективным показателем оценки лечебных мероприятий у женщин с ТПФБ, понашему мнению, должен быть показатель клинического успеха лечения, который заключался:

- купирование болевого синдрома;

- восстановление проходимости маточных труб;

- отсутствие рецидивов заболевания;

- наступление маточной беременности.

Как видно из данных таблицы 2 , после проведения лечебно-диагностической лапароскопии в течение 1 года купирование болевого синдрома в большинстве случаев удалось достичь $(62,5$ - 100\%). Проведение процедуры хромогидротубации подтвердило проходимость маточных труб во всех случаях в I группе. Во II группе восстановление проходимости одной маточной трубы произошло в $18,2 \%$, а обеих труб в $72,7 \%$ случаев. Соответственно, в III группе проходимость восстановлена в $65,1 \%$ случаев, при этом в $26 \%$ это связано с проходимостью одной маточной трубы, а в $39,1 \%$ обеих труб. В IV группе проходимость маточных труб ни в одном случае не удалось достичь из-за выраженности спаечного процесса и дистальной окклюзии в маточных трубах. Рецидивы заболевания также зависели от выраженности спаечного процесса. Так, в I группе рецидивы заболевания в течение года не наблюдались. Во II группе в $11,4 \%$ случаев пациентки вновь поступили на лечение. В III группе это количество женщин составило $47,8 \%$, а в IV группе - $75 \%$. Соответственно, наступление маточной беременности в течение года составило в группах $-35,7 \%, 22,7 \%, 8,7 \%$, а в IV группе таких случаев не отмечалось. Из этих данных вытекает, что средняя эффективность лечения в группах составила 83,$9 ; 75,5 ; 52,1 ; 21,8 \%$ соответственно.

Таблица 2. Показатели клинического успеха лечения у женщин с ТПФБ

\begin{tabular}{|c|c|c|c|c|c|c|c|c|}
\hline \multirow{3}{*}{$\begin{array}{c}\text { Показатели клинического } \\
\text { успеха лечения }\end{array}$} & \multicolumn{8}{|c|}{ Группы женщин } \\
\hline & \multicolumn{2}{|c|}{ I } & \multicolumn{2}{|c|}{ II } & \multicolumn{2}{|c|}{ III } & \multicolumn{2}{|c|}{ IV } \\
\hline & Aбс. & $\%$ & Aб́c. & $\%$ & Aб́c. & $\%$ & Aб́c. & $\%$ \\
\hline $\begin{array}{c}\text { Купирование болевого } \\
\text { синдрома }\end{array}$ & 28 & 100 & 44 & 100 & 19 & 83,6 & 5 & 62,5 \\
\hline $\begin{array}{c}\text { Восстановление } \\
\text { проходимости маточных } \\
\text { труб: } \\
\text { - одной } \\
\text { - обеих }\end{array}$ & $\begin{array}{c}- \\
28\end{array}$ & $\begin{array}{c}- \\
100\end{array}$ & $\begin{array}{c}8 \\
32\end{array}$ & $\begin{array}{l}18,2 \\
72,7\end{array}$ & $\begin{array}{l}6 \\
9\end{array}$ & $\begin{array}{c}26 \\
39,1\end{array}$ & $\begin{array}{l}- \\
-\end{array}$ & $\begin{array}{l}- \\
-\end{array}$ \\
\hline $\begin{array}{l}\text { Отсутствие рецидивов } \\
\text { ТПФБ в течение года }\end{array}$ & 28 & 100 & 59 & 88,6 & 12 & 52,1 & 2 & 25 \\
\hline $\begin{array}{c}\text { Наступление маточной } \\
\text { формы беременности в } \\
\text { течение года }\end{array}$ & 10 & 35,7 & 10 & 22,7 & 2 & 8,7 & - & - \\
\hline $\begin{array}{c}\text { Средняя эффективность } \\
\text { лечения } \\
\end{array}$ & & 83,9 & & 75,3 & & 52,1 & & 21,8 \\
\hline
\end{tabular}




\section{Обсуждение}

Из представленных данных вытекает, что степень развития спаечного процесса при ТПФБ существенно влияет на динамику восстановления репродуктивной функции женщин и, чем выраженней степень изменений спаечного процесса в малом тазу, тем восстановление происходит медленней, а также возрастает количество рецидивов заболевания, пролонгированность бесплодия также будет возрастать, что соответственно потребует дополнительного объема лечебных и реабилитационных мероприятий. Для лапароскопического лечения при ТПФБ видимо есть необходимость дифференцированного отбора больных на лапароскопию, коррекцию и выбора способа лапароскопического вмешательства. Следует согласиться с мнением некоторых исследователей $[1,5]$, что шанс положительного репродуктивного исхода уменьшается с увеличением возраста женщины и продолжительности бесплодия, окклюзии обеих маточных труб. Одним из путей профилактики образования спаек в малом тазу после лапароскопического вмешательства является не просто разработка наиболее рациональных методов эндоскопических операций, но и использование более совершенных инструментов, более физиологичных шовных материалов и современных полимеров. А также поиск новых подходов к самой операции, основанных на соблюдении принципов реконструктивно-пластической хирургии, ранняя восстановительная терапия в послеоперационном периоде, проведение по возможности наименее травматичной операции, сохранение естественного взаиморасположения органов малого таза и применение средств, улучшающих течение репаративных процессов.

\section{Заключение}

Следовательно, уточнение максимального терапевтического потенциала лапароскопических операций при ТПФБ показывает, что лапароскопия эффективна при I и II степени спаечного процесса в малом тазу, а у женщин с III - IV степенью спаечного процесса после лапароскопического доступа вмешательства в дальнейшем для восстановления фертильности показаны другие методы, в частности, проведение процедуры экстракорпорального оплодотворения.

\section{Список литературы / References}

1. Адамян Л.В., Варданян В.Г. Сравнительная характеристика и основные принципы применения физических энергий (механической, электрической, ультразвуковой и электромагнитной) при эндоскопических, реконструктивно-пластических операциях у гинекологических больных / Эндоскопия в диагностике, лечении и мониторинге женских болезней. Москва, 2000. С. 73-77.

2. Алиева Х.Г., Калиева Г.М. Лапароскопические возможности лечения внематочной беременности / Проблемы репродукции. Спец. Вып., 2009. С. 226-236.

3. Айламазян Э.К. Дмитрий Оскарович Отт - Основоположник эндоскопии в гинекологии / Журнал акушерства и женских болезней. Вып. 3., 2001. С. 8 - 14.

4. Бекмурзиева Л.К. (2009). Профилактика и лечение послеоперационного спаечного процесса у гинекологических больных: автореф. дис.... канд. мед. наук. Москва. 27 с.

5. Бурдули Г.М., Фролова О.Г. Причины и технология анализа репродуктивных потерь. Москва: Изд-во «Триада-Х», 2008. 128 с.

6. Гаспаров А.С., Волков Н.И. и Назаренко Т.А. Эндоскопия в сохранении и восстановлении репродуктивной функции / Журнал акушерства и женских болезней. Т. 50. Вып. 3, 2001. C. 90-95.

7. Здановский В.М., Фандеева Л.В. Хирургическое лечение трубно-перитонеального бесплодия лапароскопическим доступом / Проблемы репродукции. № 3, 2000. С. 48-49.

8. Корнеева И.Е. Значение эндоскопических методов обследования при бесплодном браке / Журнал акушерства и женских болезней. Т. 50. Вып. 3, 2001. С. 52-56.

9. Кулаков В.И. Лапароскопия при лечении больных с трубно-перитонеальным фактором бесплодия / Эндоскопия в диагностике, лечении и мониторинге женских болезней. Москва, 2000. C. $162-163$.

10. Кулаков В.И., Адамян Л.В. Эндоскопическая хирургия в гинекологии: состояние и перспективы развития / Журнал акушерства и женских болезней, 2001. № 1. С. 74-76.

11. Прини Д.Г., Чернышев И.В. и Антипова О.М. Эффективность оперативной лапароскопии в лечении бесплодия различного генеза / Эндоскопия в диагностике, лечении и мониторинге женских болезней. Москва, 2000. С. 160-161. 
12. Рыбников C.B. Результаты лечения трубно-перитонеальной формы бесплодия эндоскопическим методом / Репродуктивное здоровье женщины - национальная проблема России: матер. науч.-практич. конф. Кемерово, 2000. С. 120-122.

13. Чеченова Ф.К., Краснопольская К.В. Отдаленные результаты хирургического лечения трубно-перитонеального бесплодия лапароскопическим доступом / Акушерство и гинекология, 2001. № 2. С. 40-44.

14. Шухман М.Г. Эффект лапароскопии в диагностике и лечении женского бесплодия / Эндоскопия в гинекологии. Москва, 1999. С. 191-192.

15. Capelo F.O., Kumar A., Stein-Kampf N.P. et al. Laparoscopic evaluation following failure to achieve pregnancy after ovulation induction with clomipheme citrate / Festil. Steril., 2003. Vol. 80. № 6. P. 1450-1453.

16. Frey C., Poncelet C. Endoscopic management of ectopic pregnancy / Gynecol. Obstet. Fertil., 2011. Vol. 39. № 11. P. 640-643.

17. Gorry A. Laparoscopic management of abdominal ectopic pregnancy using Floseal Hemostatic Matrix / Int. J. Gynecol Obstet., 2012. V. 17. № 1. P. 83-84.

18. Molina Sosa A. Conservative laparoscopic and medical treatment of ectopic pregnancy / Ginecol. Obstet. Mex., 2007. Vol. 75. № 9. P. 539-548.

19. Hulka J.F., Reich H. Text book of laparoscopy. Philadelphia, 1998. 548 p.

20. Yoon B.S., Park H., Seong S.J. et al. Single - port versus conventional laparoscopic salpingectomy in tubal pregnancy: a comparison of surgical outcomes / Eur. J. Obstet. Gynecol. Reprod. Biol., 2011. Vol. 159. № 1. P. 150-153.

\title{
ЭПИДЕМИОЛОГИЯ И ПАТОГЕНЕЗ ТУБЕРКУЛЕЗА ПЕРИФЕРИЧЕСКИХ ЛИМФАТИЧЕСКИХ УЗЛОВ (ОБЗОР ЛИТЕРАТУРЫ) Човдурбаев Н.Ж. Email: Chovdurbaev1791@scientifictext.ru
}

\author{
Човдурбаев Нурпеис Жумабаевич - соискатель, \\ Отделение хирургического лечения внелегочного туберкулеза, \\ Национальный научный центр фтизиопульмонологии, г. Алматы, Республика Казахстан
}

\begin{abstract}
Аннотация: в данной статье освещень эпидемиологические показатели и патогенез внелегочного туберкулеза, а именно туберкулеза периферических лимфатических узлов, в Казахстане, Российской Федерации и некоторых странах Европь и Америки. Увеличение распространенности лимфаденопатий, в том числе туберкулезного лимфаденита, отмечаемое во всем мире, в значительной степени связано и с усиливающимся экологическим воздействием на человека. Высокая заинтересованность лимфатической системы в распространении туберкулезной инфекции, особенности строения, функции лимфатического узла, морфофункииональных изменений, развивающихся в лимфоузле при прогрессировании специфического воспаления, могут служить обоснованием для поиска более совершенных диагностических и лечебных методик данного заболевания.
\end{abstract}

Ключевые слова: внелегочный туберкулез, эпидемиология, патогенез, лимфатическая система, иммунный статус, туберкулез периферических лимфатических узлов.

\section{EPIDEMIOLOGY AND PATHOGENESIS OF TUBERCULOSIS OF PERIPHERAL LYMPH NODES (LITERATURE REVIEW) Chovdurbaev N.Zh.}

\author{
Chovdurbaev Nurpeis Zhumabaevich - applicant, \\ DEPARTMENT OF SURGICAL TREATMENT OF EXTRAPULMONARY TUBERCULOSIS \\ NATIONAL SCINCE CENTER PHTHISIOPULMONOLOGY, ALMATY, Republic of Kazakhstan
}

Abstract: this article highlights the epidemiological parameters and pathogenesis of extrapulmonary
tuberculosis, namely tuberculosis of peripheral lymph nodes in Kazakhstan, the Russiun Federation
and some countries of Europe and America. Increased prevalence of lymphadenopathy, is celebrated 
in all the world, largely due to increasing environmental and human exposure. The high interest of the lymphatic system in the spread of tuberculosis infection, structural features, lymph node function, morphological and functional changes developing in the lymph node in the progression of specific inflammation can serve as a basis for a more advanced diagnostic and treatment methods of this disease. The exesting problem of tuberculosis of the peripheral lymph system still retains its hyip. It should be noted that there are many unresolved issues in the field of diagnostics, clinical picture and treatment of tuberculous lymphadenitis was the basis for this study.

Keywords: extrapulmonary tuberculosis, epidemiology, pathogenesis, lymphatic system, immune status, tuberculosis of peripheral lymph nodes.

УДК: 616.428.-002.5-036.22-0.92

Туберкулез по-прежнему является глобальной эпидемической проблемой всего мира. Внелегочный туберкулез (ВЛТ) обладает меньшей контагиозностью, чем туберкулез органов дыхания, но своевременное распознавание экстраторакальной формы туберкулеза представляет сложную клиническую и организационную задачу, поскольку требует тесного взаимодействия врачей различного профиля [9]. Часто диагностируется в запущенном состоянии, на стадии осложнений и необратимых изменений, что обусловливает высокий процент инвалидизации [5]. На сегодняшний день удельный вес ВЛТ в Казахстане составляет 14,6\% от общей заболеваемости туберкулезом [16], при этом туберкулезный лимфаденит занимает второе место. В Российской Федерации в структуре общей заболеваемости внелегочные формы составляет $16,1 \%[10]$.

В семидесятые годы XX века туберкулез периферических лимфатических узлов (ТПЛУ), по данным литературы, в СССР занимал в структуре ВЛТ 3 - 4 места [7]. К началу 90-х годов, он составил в различных регионах СНГ от $23,1 \%$ до $43 \%$ случаев [6]. При этом, по статистике таких зарубежных стран как Дания, Румыния, Венгрия, ТПЛУ составил 16 - 19\% [22], в Польше - $8,2 \%$ от общей заболеваемости туберкулезом, а общий удельный вес внелегочных локализаций туберкулеза достигал $34,2 \%$ случаев [32]. По показателю заболеваемости ВЛТ лидируют страны Юго-Восточной Азии, Африки и Восточно-Средиземноморского региона. Однако в последние годы и в высокоразвитых странах как США, Канаде и странах Европы отмечен рост числа наблюдений экстраторакольного туберкулеза [29]. Так, в 2011 году в США на долю ВЛТ приходилось $15 \%$, а в Европе $12 \%$ всех случаев вновь выявленного туберкулеза [28]. Некоторые публикации указывают на то, что данное заболевание распространено в основном среди лиц старше 40 лет [34], а по другим источникам литературы, напротив, отмечается высокий процент заболевания у молодых и лиц среднего возраста (20 - 40 лет) [27].

При ТПЛУ патологический процесс чаще всего локализуется в ЛУ шейной и подчелюстной области $61,1 \%$ - 95,7\% случаев [21]. Реже встречается туберкулезный лимфаденит в подмышечной $15,0 \%$ - 17,0\% и паховой 7,0\% - 8,0\% областях [33]. Большинство авторов приводят весьма разноречивые данные. Сообщается, что ТПЛУ в основном протекает с изолированным поражением одной из групп лимфатических узлов (ЛУ) [20], а в других говорится, что чаще поражается несколько групп ЛУ, иногда и с обеих сторон [26]. Имеются сведения, что женщины в 1,2 - 3,5 раза чаще болеют ТПЛУ, чем мужчины [19]. А в работе других авторов доказано обратное, что болеют преимущественно мужчины [11].

В настоящее время механизм патогенеза ТПЛУ [24] позволяет рассматривать заболевание, прежде всего, как регионарный туберкулезный лимфаденит. После проникновения микобактерий (МБТ) в организм вследствие локальной реакции регионарной лимфатической системы развивается ТПЛУ. Распространение инфекции происходит по лимфатическим путям и кровеносному руслу, развивается общая иммунная реакция с участием всех компонентов лимфатической системы организма, при длительном сохранении доминирующей роли первоначально пораженных туберкулезом ЛУ [25]. В дальнейшем возможна местная эндогенная реактивация процесса и развитие ТПЛУ, причем между первичным туберкулезным поражением ЛУ и развитием ТПЛУ в виде самостоятельного заболевания, как правило, может проходить длительный латентный период. Такое же мнение имели Б.М. Ариэль и Э.Н. Беллендир, по данным, которых в большинстве случаев, ТПЛУ является «послепервичным регионарным туберкулезом» [1].

В связи с применением антибиотиков широкого спектра действия и клиническим патоморфозом туберкулеза в последние годы значительно возросла актуальность диагностики и дифференциальной диагностики ТПЛУ с аденопатиями другой этиологии. Следует отметить, что зачастую, больные лимфаденитом периферических ЛУ в стадии обследования в сети ПМСП, получают курсы неспецифической антибактериальной терапии, физиотерапевтические 
и другие лечебные процедуры, которые на определенное время, в зависимости от длительности проводимой терапии, стирают реальную клиническую картину заболевания [8].

Э.Н. Беллендир [2] выделяет четыре стадии в развитии специфического процесса в ЛУ: I стадия - начальная, пролиферативная, которая делится на раннюю - гиперпластическую (1a) без специфических изменений и гранулематозную (1б), когда формируются туберкулезные бугорки; II стадия - казеозная, без размягчения и распада; III стадия - абсцедирующая; IV стадия - свищевая (язвенная). Данная классификация до настоящего времени не потеряла актуальности и помогает оценить своевременность диагностики ТПЛУ. Так, выявление больных на I стадии считается ранним, во II - своевременным, в III - поздним, в IV запущенным. При постановке диагноза туберкулеза периферических лимфатических узлов помимо стадии указывают локализацию и протяженность процесса, фазу, факт бактериовыделения (при свищевой стадии). При этом не исключается возможность применения других клинических и патологоанатомических классификаций [18].

Некоторые авторы, развитие специфического процесса в ЛУ связывают как с лимфотропностью МБТ, а также и с барьерной и саногенетической функцией ЛУ. При этом большую патогенетическую роль в развитии заболевания играет возможность лимфогематогенного распространения инфекции, как из свежих, так и из старых очагов в легких, из внутригрудных и внутрибрюшных ЛУ в результате реактивации в них туберкулезного процесса [3].

Имеются различные мнения о патогенезе и его взаимосвязи с легочным туберкулезом. Одни авторы утверждают, что ТПЛУ является заболеванием общего характера, связанным с легочным туберкулезом, в связи с чем, туберкулез определяется как заболевание всей лимфатической системы [23]. При этом по мнению С.В. Зайкова [4], распространение МБТ происходит из очагов первичного комплекса в периферические ЛУ при лимфогенной и лимфожелезистой генерализации процесса. Другие авторы считают, что ТПЛУ является строго местным заболеванием, и находят доказательства в многочисленных клинических наблюдениях. Так, AN. Olu-eddo и CE. Omoti [30] исследовали 239 больных с ТПЛУ и из них только у $6,7 \%$ больных в легочной ткани были обнаружены рентгенологические изменения специфического характера. После инфицирования организма МБТ некоторое время циркулируют в крови, а впоследствии отмечается преимущественная локализация их в лимфатической системе, так называемая лимфатическая стадия. Развитие специфического процесса в ЛУ связывают с лимфотропностью микобактерий туберкулеза, с барьерфиксирующей функцией ЛУ, а также с бедностью их ферментов, играющих роль в обеспечении резистентности тканей (липазы фосфатазы) [35].

По данным М.И. Перельман и И.В. Богадельникова, из всех наблюдаемых больных с ТПЛУ у $80 \%$ пациентов не обнаружили туберкулезного поражения других органов и тканей. На основании этого авторы сделали вывод, что данное заболевание имеет сугубо местный характер, при котором первичное внедрение туберкулезной инфекции происходит через слизистую ротовой полости и носоглотки [13]. Ряд исследователей так же указывает на глоточные миндалины, которые являются первичным очагом внедрения МБТ, через них распространение происходит по лимфатическим сосудам с дальнейшим поражением регионарных ЛУ [15]. При хроническом процессе неспецифической этиологии у больных создаются условия для проникновения МБТ через слизистые полости рта, носоглотки, миндалины, конъюнктиву глаз, кожу, с последующим вовлечением в процесс регионарных шейных, подчелюстных, подмышечных и других групп ЛУ. В таких случаях лимфаденит является компонентом первичного туберкулезного комплекса. Первичный аффект протекает под маской какого-либо заболевания ротовой полости [12]. Кроме возможности лимфогенного распространения туберкулеза через кожу и слизистые, в литературе имеются указания на эндогенный - лимфогематогенный путь возникновения периферических лимфаденитов из других очагов туберкулеза. Быстрое увеличение распространенности лимфаденопатий, в том числе туберкулезного лимфаденита, отмечаемое во всем мире, в значительной степени связано и с усиливающимся экологическим воздействием на человека [17]. Таким образом, в результате инфицирования происходит оседание возбудителя в лимфатическом аппарате с последующим его размножением и рассеиванием в организме с образованием локальных форм туберкулеза. Степень выраженности изменений, возникающих в лимфатической системе при туберкулезе, зависит как от общей реактивности организма, так и от массивности и вирулентности возбудителя.

Опыты, проводимые В.П. Петуховым и В.П. Цоктоевым [14], позволили установить, что микроциркуляция в ЛУ и окружающих его тканях при туберкулезе существенно изменяется. Кроме этого нарушается лимфоциркуляция, ухудшается обмен в тканях с развитием дистрофических и некротических изменений. Возникает полная или частичная блокада ЛУ, 
которая приводит к нарушению проходимости синусов. В этом случае развивается лимфостаз с расширением лимфатических сосудов. Степень дилатации последних может быть такой, что клапаны не смыкаются, и не прикрывают полностью просвет лимфатических сосудов с тем, чтобы воспрепятствовать перемещению лимфы в обратном направлении из лимфатических сосудов с повышенным вследствие лимфостаза давлением сосуды с меньшим давлением. Возникает ретроградный и латеральный ток инфицированной лимфы с миграцией микробов в соседние органы [31].

При туберкулезном лимфадените классическая цитологическая картина характеризуется наличием эпителиоидных клеток, сгруппированных среди участков лимфоцитов и лимфобластов, скудностью плазматических клеток. В случаях значительного фиброзирования и гиалинизации бугорков, установить цитологический диагноз туберкулеза сложно, а иногда и не представляется возможным.

Заключение: таким образом, высокая заинтересованность лимфатической системы в распространении туберкулезной инфекции, особенности строения, функции лимфатического узла, морфофункциональных изменений, развивающиеся в лимфоузле при прогрессировании специфического воспаления и морфологические изменения с расстройствами гемо- и лимфоциркуляции в пораженном туберкулезом лимфатическом узле, настолько глубоки, что не позволяют обеспечить достаточно высокие концентрации противотуберкулезных препаратов в нем при различных методах их введения. Все это послужило обоснованием для поиска более совершенных диагностических и лечебных методик данного заболевания.

\section{Сиисок литературы / References}

1. Ариэль Б.М., Беллендир Э.Н. Туберкулез периферических лимфатических узлов // Руководство по легочному и внелегочному туберкулезу. Науч. ред. Левашев Ю.Н., Репин Ю.М.СПб: ЭЛБИ-СПб; 2008. 544 с.

2. Беллендир Э.Н. Патогенетические предпосылки к разработке эволюционной классификации гематогенных («метастатических») форм внелегочного туберкулеза // Проблемы туберкулеза, 1986. № 8. С. 64-68.

3. Гурьева О.И, Кравченко А.Ф., Аксенова В.А. Особенности клинических проявлений туберкулеза периферических лимфатических узлов у детей и подростков // Якутский медицинский журнал, 2009. № 4. С. 49 - 52.

4. Зайков C.B. Дифференциальная диагностика синдрома лимфаденопатии // Клиническая иммунология. Аллергология. Инфектология, 2012. № 4. С. 54-59.

5. Ковешникова E.Ю., Кульчавеня E.B. Туберкулезный спондилит сегодня: клиникоэпидемиологические особенности // Медицина и образование в Сибири, 2012. № 2. C. 147-150.

6. Кочеткова Е.Я., Худякова Р.В. Структура клинических форм у впервые выявленных больных внелегочным туберкулезом // Туберкулез сегодня: Материалы VII Рос. съезда фтизиатров. М., 2003. С. 176-177.

7. Кочнева И.Е., Сухановский В.П., Ильяш И.Н. и др. Об особенностях современного туберкулеза у детей // Проблемы туберкулеза, 1981. № 1. С. 17-20.

8. Крутько В.С., Потейко П.И., Ходош Э.М. Туберкулез периферических лимфатических узлов // Медицина неотложных состояний, 2013. № 1 (48). С. 151-153.

9. Кульчавеня E.В., Краснов В.А. Избранные вопросы фтизиоурологии. Новосибирск: Наука, 2010. $142 \mathrm{c}$.

10. Кульчавеня Е.В., Краснов эпидемиологической ситуации по внеторакальному туберкулезу // Туберкулез и болезни легких, 2013. № 12. С. 34-39.

11. Мордык А.В. Яковлева А.А., Николаева И.Н. и др. Актуальность проблемы внелегочного туберкулеза в современных эпидемиологических условиях // Тихоокеанский медицинский журнал, 2015. № 3. С. 19-21.

12. Нечаева О.Б. Ситуация по туберкулезу и ВИЧ-инфекции в России // Туберкулез и болезни легких, 2014. № 6. С. 9-15.

13. Перельман М.И., Богадельникова И.В. Фтизиатрия / М.И. Перельман, М.: ГЭОТАР - Медиа, 2010. $448 \mathrm{c}$.

14. Петухов В.П., Цоктоев В.П. Комплексное лечение туберкулеза периферических лимфатических узлов / В.П. Петухов, // Сибир. мед. журнал, 2008. № 1. С. 64-65. 
15. Старков Д.А. Мусоbacterium avium - Актуальный возбудитель микобактериоза человека // Инфекция и иммунитет, 2013. № 3. С. 7-14.

16. Статистический сборник по туберкулезу в Республике Казахстан / Под ред. Т.Ш. Абилдаева. Алматы, 2015. С. 68.

17. Чеботарева Т.В., Облогина Л.И., Косинова А.М. и др. Случай генерализованного туберкулеза периферических и мезентериальных лимфатических узлов и стенки тонкой кишки у ребенка // Вестник Ивановской мед. Академии, 2009. № 3. С. 54-59.

18. Шпрыков А.А., Елипашев А.А., Никольский В.О. Влияние табакокурения на активность туберкулезного воспаления (по морфологическим данным) // Медицинский альманах, 2010. № 2. C. 291-293.

19. Яблонский П.К., Мушкин А.Ю., Белиловский Е.М. и др. Внелегочный туберкулез // Туберкулез в Российской Федерации. 2010. Аналитический обзор статистических показателей, используемых в Российской Федерации. М., 2011. С. 111-116.

20. Chhabra S., Saharan K., Pohane D. Pelvic tuberculosis continues to be a diseas of dilemma - case series // Indian. J. Tuberc., 2010. Apr. 57 (2). P. 90-94.

21. Cuadros N., Artigao B. Recommendation from the Spanish Society of Pediatric Infectious Diseases on the diagnosis and treatment of non-tuberculous mycobacterial cervical lymphadenitis // An. Pediatr. (Bars), 2012. Sep. 77 (3). P. 208-212.

22. Ebdrup L., Storgard M., Jensen-Fangels S. et al. Ten years of extrapulmonary tuberculosis in a Danish University clinic // Scand. J. Infect. Dis., 2003. Vol. 35. № 4. P. 244-246.

23. Fontanilla J.M., Barnes A., Reynvon C.F. Current diagnosis and management of peripheral tuberculous lymphadenitis // Clin. Infect. Dis., 2011. Sep. 53 (6). P. 555-562.

24. Fukui S., Takizawa Y., Kubota N. et al. Tuberculous lymphadenitis and the appearance of Behcets disease-like symptoms // Intern. Med., 2014. Vol. 53. № 7. P. 805-808.

25. Guinchard A.C., Pasche P. Periferal tuberculous lymphadenitis: diagnosis and management // Rev. Med. Suisse, 2012. Oct. 8 (356). P. 1860-1862, 1864-1865.

26. Jawahar M.S., Rajaram K., Sivasubramanian S. Treatment of lymph node tuberculosis-a randomized clinical trial of two 6-month regimens // Indian J. Pediatr., 2005. Nov. 10 (11). P. 1090-1098.

27. Kamal M.S., Hoque M.H., Chowdhury F.R. et al. Cervical tuberculous lymphadenopathy: Clinicodemographic profiles of patients in a secondary level Hospital of Bangladesh // Pak. J. Med., 2016. May-Jun. 32 (3). P. 608-612.

28. Mazza-Stalder J., Nicod L., Janssens J.P. et al. Extrapulmonary tuberculosis // Rev. Mal. Respir., 2013. Apr. 29 (4). P. 566-578.

29. Mesquita M., Libertalis M., Bakoto E.S. et al. Late diagnosis of extra-pulmonary tuberculosis leads to irreversible kidney failure in a non-immunocompromised patient // Int. Urol. Nefrol., 2010. Mar. 42 (1). P. 227-232.

30. Olu-eddo A.N., Omoti C.E. Diagnostic evalution of primary cervical adenopathies in a developing contry // Pan. Afr. Med. J., 2011. Des. 10 (52). P. 20-25.

31. Richner S., Laifer G. Peripheral lymphadenopathy in immunocompetent adults // Swiss. Med. Wkly, 2010. Fev. 140 (7-8). P. 98-104.

32. Rowinska-Zakrzewska E., Korzeniewska-Kosela M., Roszkowski-Sliz K. Extrapulmonary tuberculosis in Poland in the years 1974-2010 // Pneumonol. Alergol Pol., 2013. Vol. 81 (2). P. 121-129.

33. Ueda T., Murayama T., Hasegawa $Y$. et al. Tuberculous lymphadenitis: a clinical study of 23 cases // Kekkaku., 2004. May. 79 (5). P. 349-354.

34. Weiler Z., Nelly P., Baruchin AM. et al. Diagnosis and treatment of cervical tuberculous lymphadenitis // J. Oral. Maxillofac. Surg., 2000. May. 58 (5). P. 477-481.

35. Sathekge M., Maes A., Asselr Y. et all. Tuberculous lymphadenitis FDS PET and CT findings in responsive and nonresponsive disease // Eur. J. Nucl. Med. Mol. Imaging., 2012. Jul. 39 (7). P. 1184-1190. 


\title{
ВОПРОС ВЫБОРА ПРОФЕССИИ ДЛЯ БУДУЩЕГО ПОКОЛЕНИЯ - ТРЕБОВАНИЕ ВРЕМЕНИ Мирпаязов Б.A. Email: Mirpayazov1791@scientifictext.ru
}

\author{
Мирпаязов Баходир Алимович - доцент, \\ кафедра исполнительства на народных инструментах, \\ Государственная консерватория Узбекистана, г. Ташкент, Республика Узбекистан
}

\begin{abstract}
Аннотация: каждый специалист должен жить своей профессией. Только тогда выполняемая работа будет осуществляться с любовью. Во всех сферах современной общественнополитической жизни решающую роль в достижении прогресса гражданского общества играют такие качества, как ум, творческое мышление, интеллектуальный потенциал, использование новых техник и технологий.

При выборе профессии следует изучить рынок востребованности труда. Владение информацией о профессиях даёт возможность её выбора с учётом своих пожеланий. Для этого необходимо постоянно повымать свою квалификацию и быть готовым к тому, что в любой момент может открыться шанс получения той или иной престижной должности.

Ключевые слова: специалист, новые технологии, молодёжь, профессия, педагог, мастер.
\end{abstract}

\section{QUESTION OF THE CHOICE TO PROFESSIONS FOR FUTURE GENERATION - A REQUIREMENT OF TIME \\ Mirpayazov B.A.}

\author{
Mirpayazov Bakhodir Alimovich - Assistant professor, \\ PULPIT "PERFORM ON PUBLIC INSTRUMENT" \\ STATE CONSERVATORY OF UZBEKISTAN, TASHKENT, REPUBLIC OF UZBEKISTAN
}

\begin{abstract}
Only then executed work will be realized with love. In all sphere modern public-political life solving role in achievement of the progress civil society play such quality as wit, creative thinking, intellectual potential, use new technician and technology.

When choosing a profession should examine labor market demand. Possession of information about professions allows its choice, taking into account their wishes. To do this, you must continually upgrade their skills and to be prepared for the fact that at any time can open the chance of getting this or that prestigious post.
\end{abstract}

Keywords: specialist, new technologies, youth, profession, teacher, master.

УДК 85.31

На сегодняшний день реформирование содержания и качества труда, ориентированного на целенаправленный выбор молодёжью желаемой профессии, стал важной социальноэкономической задачей. И это закономерно, поскольку в условиях ускоренного научного, общественно-экономического и культурного развития государства, число молодых людей, обладающих высокими духовными качествами и вносящих достойный вклад в развитие страны, растёт изо дня в день. Причина этого явления кроется прежде всего в том, что в годы обретения Узбекистаном независимости были созданы прочный фундамент и соответствующие условия для развития таланта молодёжи. В этой связи важно подчеркнуть, в последнее десятилетие чрезвычайно актуализировалась проблема усовершенствования подготовки кадров, особенно в отраслевом разрезе, где бы она могла осуществляться на альтернативной основе в виде конкретного плана с учётом социального заказа, потребностей в кадрах по специальностям и достижений науки и техники.

Ориентирование кадров на выбор профессии, их подготовка и повышение квалификации в Узбекистане подняты на уровень государственной политики. Особое внимание уделяется созданию системы непрерывного образования как важного аспекта, имеющего непосредственное отношение к данной теме. Законы «Об образовании» и «Национальная программа подготовки кадров», исследования, созданные в республике и за рубежом, посвящённые вопросам системного анализа формирования личности, целенаправленности 
выбора профессии, пропагандирующие педагогические и психологические аспекты, являются методической основой.

Как известно, правильный выбор профессии с учётом желания плодотворно работать являются важным фактором при определении самостоятельного пути в жизни. Вот почему в Узбекистане обучение, овладевание знаниями, выбор профессии и направление деятельности осуществляются на базе «Национальной программы подготовки кадров» [1, 281].

Человек на протяжении своей жизни должен уметь правильно выбрать профессию, определить степень её соответствие своим интеллектуальным возможностям, наклонностям и интересам. Для этого выбирающий должен учесть целый ряд требований, а именно: систему подготовки специалиста, условия труда, средства и особенности данной отрасли, оценить свои возможности и потребности, получить сведения о профессии с учётом изменений рыночных отношений, определить соответствие своего избираемой специальности, знать об условиях совершенствования своего образования и иметь сведения о статусе будущей профессии [2, 37].

Обучающиеся должны суметь сделать грамотный анализ избираемой профессии, оценить степень своего здоровья и интересов, сравнить требования, предъявляемые к данной профессии со своими личными особенностями и только после этого строить план освоения той или иной специальностью. Кстати, воспитание молодого поколения, умеющего с уверенностью смотреть в будущее и самостоятельно мыслить, является основной задачей. В этой связи закономерен вопрос: на что же следует обратить внимание?

Прежде всего необходимо чётко выявить интересы и уровень способностей молодого поколения, дать ему правильное направление и, по мере возможности, помочь советом. Бывают случаи, когда молодёжь поступает в учебное заведение, не имея интереса. В результате, учёба проходит как бы «впопыхах», без особого желания и вызывает чувства охлаждения и нежелание полноценно освоить секреты профессионального мастерства. После такого поверхностного обучения молодой человек не может найти своего места в жизни. Вот почему необходимо всячески содействовать выявлению у учащихся уже с детских лет их стремлений и наклонностей, определение уровня способностей, которые бы способствовали правильному выбору специальности.

Важно отметить, что на пути системного изучения вопросов, связанных с выявлением природных данных и способностей ребёнка, его интересов и возможностей стоит ряд важных ступеней. В их числе семья, дошкольное образование, общеобразовательная школа, укрепление совместных усилий со средним специальным профессиональным образованием, установление эффективных связей со сферой производства, и, наконец, самое главное -своевременный анализ полученных результатов и составление плана работ на будущее. Эти задачи в первую очередь требуют укрепления контактов между учителем и родителями. Известно, что с момента рождения интересы и таланты ребёнка прежде всего выявляются родителями и именно они бывают в курсе его мечтаний и возможностей. Поэтому учебному заведению рекомендуется проводить регулярные встречи, беседы, «круглые столы» с родителями, внушая им важность их усилий по воспитанию ребёнка в семье ибо, в конечном счёте, это поможет решить вопросы следующего этапа.

При выборе профессии будуший специалист должен иметь полную информацию о месте работы и его гарантированности. К сожалению, на сегодняшний день выпускники средних специальных профессиональных учебных заведений сталкиваются с определёнными препятствиями, которые зачастую связаны с невыполнением работодателями порядка трудоустройства. Они избегают необходимости заключения трёхстороннего договора с выпускником и потому не берут на себя обязательства обеспечения их работой. Таким образом к наступлению срока поступления молодого человека на работу, организациями выдвигаются различные причины для отказа в предоставлении рабочего места. В этой связи необходимо устанавливать связи между организациями и центрами занятости, причём уже во время прохождении учащимися квалификационной практики. В таких условиях обеспечение молодых специалистов работой происходит с учётом потребностей кадров на рынке трудоустройства. Свою позитивную лепту в этом направлении вносят, в частности, и такие мероприятия как «День открытых дверей».

Выбор профессии, к которой «лежит душа» гарантирует эффективную и плодотворную работу человека в будущем. К сожалению, в последние годы участились случаи выбора профессии с возможностью получения высоких материальных доходов, тогда как вопрос об удовлетворённости работой стоит на втором плане. В этом случае следует принимать во внимание тот факт, что работа, не вызывающая энтузиазма, не может обеспечить высокий доход, а значит и заинтересованность. Наблюдения свидетельствуют, что удовлетворённость 
своей работой приводит к успеху, и наоборот, разочарованность сопровождается бесполезным времяпровождением. Человек, любящий свою профессию и получающий от неё удовлетворение, добивается значительно больших результатов в отличие от того, кто не любит свою работу и потому терпит материальные трудности. Вот почему при выборе будущей профессии следует учитывать не только ожидаемую от неё материальную выгоду, но и возможность получения духовной пищи. Если при выборе профессии не ощущается тяготение души, удовлетворение от выбранной работы, нужно стремиться искать в ней такие аспекты от своего труда, которые способствовали бы рождению чувства радости и привносили бы в неё осмысленность. В случае, если такие стимулы не действуют, рекомендуется сменить профессию на ту, которая приносила бы удовлетворение.

Каждый специалист должен жить своей профессией. Только тогда выполняемая работа будет осуществляться с любовью. Во всех сферах современной обществено-политической жизни решающую роль в достижении прогресса гражданского общества играют такие качества как ум, творческое мышление, интеллектуальный потенциал, использование новых техник и технологий.

При выборе профессии следует изучить рынок востребованности труда. Владение информацией о профессиях даёт возможность её выбора с учётом своих пожеланий. Для этого необходимо постоянно повышать свою квалификацию и быть готовым к тому, что в любой момент может открыться шанс получения той или иной престижной должности.

Как известно, выбор профессии определяет судьбу человека. Вот почему определение профессии должно находиться в центре внимания с ранней молодости. К сожеланию, нередки случаи неудовлетворённости своей профессией, отказ от неё, увлечение другой профессией и переход к роду деятельности, которая вызывает большее желание работать с охотой. Даже если по происшествии времени Вы решили отказаться от первой профессии ради той, которая Вас больше заинтересовала, в жизни могут случаться разные обстоятельства, которые надо иметь в виду. В частности, нередко для обретения навыков по вновь избираемой профессии могут помочь знания, полученные по первой специальности через межпредметные дисциплины. В конечном счёте в современном мире прогресс общества связан с появлением таких талантливых людей, которые, будучи совершенными специалистами в одной области, могут стать гордостью в другой. Конечно, учёт престижности той или иной профессии явление естественное, однако, для успешного осуществления своей цели всё же важно считаться со своими интересами, способностями, здоровьем и возможностями. При выборе некоторых профессий, кроме желания, важно учитывать и состояние здоровья, которое может ухудшиться. Ведь есть такие профессии, которые требуют длительных физических усилий.

Нами предлагаются некоторые рекомендации для учёта физиологического состояния человека при выборе условий труда:

Так, для определённых профессий кроме способностей необходимо учитывать состояние своего здоровья, но и этот фактор не всегда бывает решающим. Обычно подробные рекомендации даются после медицинского обследования, потому что выбирающий должен знать об ограничениях, касающихся пределов физических нагрузок по данной профессии. Перед принятием решения о выборе такой профессии важно посоветоваться с врачом. Но и сам претендент тоже должен адекватно оценить состояние своего здоровья. Известно, что в определённых случаях недостатки, наблюдаемые в организме, могут привести к отрицательным последствиям. Например:

- при наличии болезней суставов и позвоночника, недостаточного развития мускулатуры, требование большой физической энергии, необходимость длительного стояние на ногах, частое нагибание и др. - не рекомендуется выбор профессии, требующей таких качеств;

- при наличии неполноценного функционирования органов осязания (зрение, слух, разпознавание запахов, вкуса пищи) не рекомендуется выбор таких профессий, как вождение всех видов транспорта, отдельные виды искусства, производство продовольствия, парфюмерная промышленность.

На что же следует акцентировать внимание при выборе профессии:

Родители должны не забывать о ребёнке, его способностях и наклонностях, не требовать подчинения их воле, а наоборот, оказать помощь для осуществления их желаний. В большинстве случаев родители, к сожалению, диктуют свои требования, оказывая давление на выбор желаемой профессии.

В настоящее время большинство молодёжи увлекается такими модными профессиями как экономист, юрист, менеджер, брокер, дилер, между тем они могут не обладать для этого требуемыми качествами, а именно: наличие в характере деловой хватки, рвения, энтузиазма, навыков общения, высокой работоспособности. 
Часто молодое поколение выбирает профессию, подражая своим друзьям, не пытаясь выявить свои истинные способности. В итоге в очень немногих случаях выбор профессии, точнее случайные обстоятельства, дают эффективные результаты. Потому что выбирающий, даже при знании возможностей и интересов самой профессии не может полноценно оценить степень своего соответствия ей.

Иногда интерес к какому-нибудь предмету путают с соответсвующей профессией. Например, ученик легко осваивает уроки пения, хорошо запоминает песни на различные стихи, стремится к их исполнению, и это влияет на выбор профессии. Однако, сложность теоретических знаний музыкального образования, игнорирование фактора наличия особых талантов и природных способностей, в результате возникающих трудностей (в частности, учащийся не в состоянии овладеть требованиями по специальности) впоследствии приводят к охлаждению интереса к избираемой профессии и разочарованиям.

В некоторых семьях выбор профессии становится семейной традицией. Спортивные успехи старшего брата в достаточно сложной области вдохновляют и младшего, но имея слабые физические данные, он не представляет, что здесь требуется особый природный талант.

Выбор профессии, осуществляемый свои намерения с учётом возможностей - это защита от неправильного, безрезультативного шага, который поможет сэкономить время и скординировать свои данные и интересы, и тем самым помочь сделать правильный выбор.

Не имея достаточных представлений о возможностях профессии и степени её трудоёмкости, а также не обладая сведениями об уровне развития избранной профессии, особенно связанной с общественным и техническим прогрессом, также можно совершить ошибку при выборе пути. Сюда же следует отнести и случаи сокрытия новых требований, предъявляемых к выполнению того или иного труда, поэтому необходимо обладать полной информацией и о современном состоянии избираемой профессии.

Словом, к жизненно важному для молодого поколения вопросу о выборе профессии следует отнестись со всей серъёзностью. И чем больше заинтересованности в его решении проявят окружающие взрослые - родители, наставники, педагоги, тем удачнее сложится судьба молодого гражданина (юноши и девушки) нашей страны. А это значит - счастье наших детей в наших руках.

\section{Сиисок литературы / References}

1. «Будущность и проблемы развития экономического образования». Сборник статей, 2015.

2. «Вопросы профессиональной подготовки коллективного исполнительства в средних специальных учебных заведениях музыки и искусства». Сборник статей, 2016. 


\title{
KINETIC BEHAVIOR OF INTERACTIVE ARCHITECTURE Boychenko K.V. Email: Boychenko1791@ scientifictext.ru
}

\author{
Boychenko Kristina Viktorovna - Master of science in Architecture, \\ DEPARTMENT OF ARCHITECTURE AND ENGINEERING, \\ POLYTECHNIC UNIVERSITY OF MILAN, MILAN, ITALY
}

\begin{abstract}
: the article describes qualities and properties of kinetic behavior within framework of interactive architecture as one of the main features of interactive environment, considered from its' interaction with people and positive social impact point of view. Ability to change its' shape and adapt to new conditions is one of the key elements of creating new space, able to meet emerging users' needs. Since technical progress has allowed architecture to become dynamic, designers and architects seek for ways to bring life and motion into built environment, providing the opportunity of social interaction and maintaining a dialogue with users in real time.
\end{abstract}

Keywords: interactive architecture, kinetic behavior, social interaction, built environment, design.

\section{КИНЕТИЧЕСКОЕ ПОВЕДЕНИЕ ИНТЕРАКТИВНОЙ АРХИТЕКТУРЫ Бойченко К.В.}

\author{
Бойченко Кристина Викторовна -магистрант, \\ кафедра архитектуры, факультет архитектуры и инженерии, \\ Миланский политехнический университет, г. Милан, Итальянская Республика
}

\begin{abstract}
Аннотация: статья описывает особенности и свойства кинетического поведения в рамках интерактивной архитектуры как одно из основных качеств интерактивной среды с точки зрения ее взаимодействия с людьми и положсительного соииального влияния. Способность менять форму и адаптироваться к новым условиям является одним из ключевых элементов создания нового пространства, способного удовлетворить новые возникающие потребности пользователей. С тех пор, как технический прогресс позволил архитектуре стать динамичной, дизайнеры и архитекторы искали способы вдохнуть жизнь в окружающую застройку и дать ей возможность взаимодействовать с людьми в режиме реального времени.
\end{abstract}

Ключевые слова: интерактивная архитектура, кинетика, сочиальное взаимодействие, окружающая застройка, проектирование.

Usually by animation we understand simulation of movement. Though in contemporary architecture (real or virtual) animation is understood as the change of parameters in time or "the act, process, or result of imparting life, interest, spirit, motion, or activity". Greg Lynn states the difference between animation and motion as follows: "Where motion implies movement and action, animation suggests animalism, animism, evolution, growth, actuation, vitality and virtuality."

Interactive design of the public environment engaged social and cultural dimensions of space. A lot of projects have utilized the medium to engage in political arena through participation. Designers often seek for chances to use spatially defining interaction as a mechanism to understand, shape and promote social interaction. The physical space can be used to include or exclude people from one another, to facilitate, dissipate, or focus crowds. In this way, in the realm of physical architecture, interactive public spaces can have a profound effect on social interactions. It is important to point out that a lot of projects in public sphere play big role in testing the durability of materials as well as the tie frame of particular interactive strategies within the context of unpredictable participants [1].

Some experiments in contemporary design were targeted on simulation of motion of the built environment not by capturing it, but rather enhancing, creating the interaction between user and building. A dense information network, realized by means of pneumatic engines and sensors, link external impulses into building responsive reaction. This causes buildings to be variable, transitory unlike architecture conventionally was supposed to be.

The first attempt to bring real motion in architecture happened almost 100 years ago in design of Monument for the Third Internazionale by Tatlin in 1919, which was the kinetic structure, where a few 
platonic solids (cube, pyramid, cylinder) were rotating along a vertical axis at specific speed (1 rotation per year, per month or per day). The steel spiral of Tatlin tower was scheduled to be $400 \mathrm{~m}$ high.

Since that time a lot of kinetic structures were realized, continuing this trend, by means of new advanced techniques the movement can be carried out in a more effective way. For example Kuwait Pavilion for Sevilla World Expo 1992 by Santiago Calatrava, with its' mobile structure and many other cases of motion in architecture, built in recent years, becoming more and more complex with higher ability to react, move faster, more smooth and recognize triggering from users or being activated via remote data input.

Kas Oosterhuis' is one of the front men in experiments with virtual environment and interaction of the space and visitor nowadays. His experiments with interactive architecture, like Trans-ports (2001) and E-motive house (2002) proves, that interactive, animated architecture becomes feasible reality. They define possible direction of future research and implementation. The first object "acts like a muscle", connected to data (input-output devices) in real-time. It uses three main elements: electronic interior skin, pneumatic "muscles" and flexible exterior skin. Instead of being static, it is rather like a lean device, which relaxes or tightens upon different forces [2,3].

E-motive house is a weaving loop between a hard and a soft structure. The construction of the house and the furniture can be programmed in any desired way. Almost all the elements, except for kitchen and bathroom, can be changed and modified. The house acts like an interactive adaptive system. Among many well-known interactive projects one might place as well Aegis Hyposurface (dECOi, 1999-2001), Tower of Winds (Toyo Ito, 1986) and Saltwater Pavilion (Kas Oosterhuis, 1997).

Motion in architecture can be understood literally. Kas Osterhuis' project for Graphisoft Slider (2002) is a set of programmable sliding volumes, demonstrating unique and not yet experienced structural behavior. The main idea of this project relies on retaining the two old concrete crane slider bars and establishing a new mobile construction on the top of it. There are four main elements (oval cage, yellow glass box, cloudshaped functional blobs and mediatube) moving independently in continuous, unpredictable motion. The body of the project is always in motion, dynamic, alive and programmable.

Urban scale projects have changed according to the new trends as well. Traditional city concept is now influenced by trends of a hypercity, where new shops grow up and replace the old, where old squares disappear and a new perspectives arise within a months, all happens in sake of improving the social interaction and mace infrastructure of the city, built environment and public space important participants in this social relationships. This state of transformation is enhanced and supported by a network of information connections. A building, a city, an airport, a car, a human has become only a node, a vertex of a whole system, constantly moving.

Using emerging images, light, sound, moving and changing its spatial configuration intelligent space makes the user sink into the atmosphere that is created for each of the activities taken within it and able to project information in the outer shell. Smart environment proposes the whole situation for the user to get involved into this conversation with the space, full of information, hidden or exposed possibilities, choice of activities, details, games and even jokes and allusions that the user is free to intemperate as his intelligence, experience and sense of humor lets him to [4].

\section{References}

1. Boychenko Kristina. Edutainment in Interactive Environment Framework // Science, Technology and Education, 2017 / DOI: 10.20861/2312-8267-2017-32-001.

2. Boychenko Kristina. Senses and Behavior of Interactive Environment // Bulletin of Science and Education, 2017 / DOI: 10.20861/2312-8089-2017-26-001.

3. Oosterhuis Kas. Towards a New Kind of Building: A Designers Guide for Nonstandard Architecture // TU Delft, 2004.

4. Boychenko Kristina. Interactive Architecture: development and implementation into the built environment // European Journal of Technology and Design Vol. (15), March 2017. 


\title{
ВЛИЯНИЕ КЛИНИЧЕСКОЙ КАРТИНЫ ГИПОФИЗАРНОЙ НЕДОСТАТОЧНОСТИ НА ПОКАЗАТЕЛИ КАЧЕСТВА ЖИЗНИ И ВНУТРЕННЮЮ КАРТИНУ БОЛЕЗНИ ПАЦИЕНТОВ С ГИПОПИТУИТАРИЗМОМ
}

\author{
Шитова A.B. Email: Shitova1791@ scientifictext.ru
}

\author{
Шитова Алина Валентиновна - старший преподаватель, \\ кафедра иностранных языков и лингводидактики филологический факультет, \\ Санкт-Петербургский государственный университет, г. Санкт-Петербург
}

\begin{abstract}
Аннотация: в данной статье подробно рассматриваются клинические проявления гипопитуитаризма в свете дискуссии о необходимости обеспечения пациентов с данной патологией пожизненной заместительной гормональной терапией. В статье приведён обзор зарубежных исследований, в которых изучались факторы, влияющие на показатели качества жизни пациентов, а также факторы, влияющче на их внутреннюю картину болезни $и$ здоровья. Отмена терапии рассматривается как отрицательное воздействие на состояние здоровья пациента, но также это может оказывать положительное воздействие на его приверженность лечению.
\end{abstract}

Ключевые слова: гипопитуитаризм, гипофизарная недостаточность, гормон роста, качество жизни, заместительная гормональная терапия, внутренняя картина болезни, внутренняя картина здоровья.

\section{THE EFFECT OF PITUITARY HORMONE DEFICIENCY ON QUALITY OF LIFE AND ILLNESS PERCEPTION OF PATIENTS WITH HYPOPITUITARISM Shitova A.V.}

\author{
Shitova Alina Valentinovna - senior lecturer, \\ DEPARTMENT OF FOREIGN LANGUAGES AND LINGUODIDACTICS, FACULTY OF PHILOLOGY, \\ ST. PETERSBURG STATE UNIVERSITY, ST. PETERSBURG
}

\begin{abstract}
: the article discusses the clinical manifestations of hypopituitarism in the light of the discussion on the need to provide patients with this pathology with life-long hormone replacement therapy. The article gives an overview of studies that examined factors that affect the quality of life of such patients, as well as factors that affect their self-perceived illness and well-being. The withdrawal of hormone replacement therapy is seen as a negative effect on the patient's health, but it can also have a positive effect on their adherence to treatment.

Keywords: hypopituitarism, pituitary hormone deficiency, growth hormone, quality of life, hormone replacement therapy, illness perception, self-perceived well-being.
\end{abstract}

УДК 159.9:61

Гипофизарная недостаточность (ГН) или гипопитуитаризм (также ранее известный как гипофизарный нанизм), согласно МКБ-10 имеет номер Е 23.0, где под единым наименованием собран ряд различных синдромов. ГН, прежде всего, выражается в соматотропной недостаточности $(\mathrm{CH})$, зачастую сочетающейся с множественной недостаточностью тропных гормонов аденогипофиза (МДГ, пангипопитуитаризм). ГН диагностируется на основании комплексного обследования, и низкие показатели проб и анализов могут свидетельствовать о дефиците ГР и ГН. Кроме того, КТ и МРТ позволяют визуально оценить состояние гипофиза и гипоталамуса и определить имеющуюся патологию. По статистике аномалии гипоталамогипофизарной области встречаются у 93\% пациентов с врождённой СН $[1 ; 2]$. Несмотря на проявления данного заболевания, негативно сказывающиеся на качестве жизни (КЖ) пациентов, внутренняя картина болезни (ВКБ) пациентов с ГН остаётся малоизученной и противоречивой, что может отрицательно влиять на их приверженность лечению. В данной статье рассматриваются физиологические и психофизиологические факторы, потенциально обусловливающие ВКБ при гипопитуитаризме и влияющие на показатели КЖ пациентов с ГН. 
Клиническая картина болезни при ГН во многом зависит от того, дефицит каких именно гормонов и в какой степени присутствует у конкретного пациента. Одну из ведущих ролей в организме человека играет соматотропный гормон роста (СТГ). Исследования показали, что помимо стимуляции продольного роста костей и участия в обменных процессах, гормон роста (ГР) также является и нейропептидом, поскольку он способен преодолевать гематоэнцефалический барьер и воздействовать на ЦНС (рецепторы ГР, как и рецепторы гонадотропинов, были обнаружены в гиппокампе и гипоталамусе, а рецепторы ИФР-1 в префронтальной коре, гиппокампе и миндалевидном теле) [3]. Ряд плацебо-контролируемых исследований конца $90-\mathrm{x}$ гг. показали повышение концентрации $\beta$-эндорфина в цереброспинальной жидкости и снижение антагониста дофамина в ликворе у пациентов с $\mathrm{CH}$, получавших заместительную гормональную терапию (3ГТ) [4; 5]. В 50\% случаев (по данным ЭНЦ на 2004 г.) встречается дефицит СТГ + 3 тропных гормона - ГР, ТТГ, ЛГ и ФСГ. Примерно в $22 \%$ случаев встречается дефицит СТГ + 4-5 тропных гормонов, включая Прл и/или АКТГ. Дефицит пролактина и вазопрессина встречается в клинике относительно редко и в основном в случае приобретённой ГН после хирургического вмешательства ГН и компенсируется синтетическими аналогами десмопрессина. У детей и подростков дефицит пролактина не компенсируется. У взрослых пациентов с МДГ вторичный гипотиреоз встречается в $100 \%$ случаев, а в 95\% встречается вторичный гипогонадизм [6].

Клинические проявления ГН могут быть обусловлены нехваткой одного гормона, а усугубляться нехваткой других гормонов, имеющих подобное воздействие, часто обусловленное дефектами генов Pitl и Propl (контролирующих созревание клеток передней доли гипофиза), а также мутациями целого ряда других генов. Например, при МДГ на утомляемость, массу тела, состояние кожи, память, концентрацию внимания, снижение полового влечения и пр. непосредственно влияют не только уровень СТГ, но ещё и ТТГ, ЛГ, ФСГ и АКТГ. Но даже при одном и том же генетическом дефекте пациенты с ГН могут значительно отличаться друг от друга фенотипически [7].

В целом из-за воздействия ряда факторов спектр частных проявлений ГН весьма широк, а симптомы достаточно размыты, что и делает ВКБ пациентов трудной для изучения. Приведём наиболее часто встречающиеся клинические проявления гормональной недостаточности $(Г Н)$ со стороны различных систем организма. Так со стороны сердечно-сосудистой системы наблюдается снижение массы левого желудочка и сердечного выброса, быстрая утомляемость и ранний атеросклероз. Со стороны жирового обмена: увеличение количества жировой ткани и ИМТ, увеличение соотношения окружности талии к окружности бёдер и повышение уровня холестерина в крови. Со стороны костной системы: снижение массы и плотности костной ткани (остеопороз), болевой синдром и частые переломы. Со стороны мышечной системы: снижение мышечной массы и мышечной силы, снижение способности переносить физическую нагрузку, а также уменьшение толщины соединительной ткани. Со стороны почек: снижение объёма внеклеточной жидкости и скорости фильтрации. Со стороны ЦНС: нарушенное психологическое благополучие, подробнее рассмотренное нами в предыдущей статье [8]. Кроме того, дефицит СГ негативно влияет на продолжительность жизни пациента и способствует повышению уровня смертности вследствие сердечно-сосудистых заболеваний [9; 10].

Клиническая картина гипопитуитаризма не будет полной без описания сопутствующих синдромов, а именно вторичного гипотиреоза, вторичного гипокортицизма и вторичного гипогонадизма. Диагноз «вторичный гипотиреоз» устанавливается на основании низких значений свободного (общего) тироксина $\left(\mathrm{T}_{4}\right)$ и нормального или сниженного уровня тиреотропного гормона (ТТГ). У большинства пациентов уровень ТТГ находится в пределах нормы, а гипотиреоз проявляется после 3-летнего возраста. Вторичный гипотиреоз характеризуется снижением активности индивида, плохой переносимостью низких температур, сухостью кожных покровов, прибавкой в весе и нарушениями пищеварения. Пациенты с вторичным гипотиреозом получают пожизненную ЗГТ тиреоидными препаратами в индивидуально подобранной дозировке, в виде таблеток.

Диагноз «вторичный гипокортицизм» является наиболее серьёзной из всех ГН и устанавливается на основании низкого уровня кортизола в крови и моче. Клиническая картина вторичного гипокортицизма схожа с картиной гипотиреоза: гипотония, утомляемость, слабость, сухость кожи и гипогликемия. Вторичный гипокортицизм может развиться годы спустя после манифестации гипопитуитаризма, что обусловлено определёнными генетическими дефектами, установление которых может уже на ранних сроках предсказать дальнейшее развитие болезни. Заместительная терапия при гипокортицизме проводится такими препаратами как кортеф, кортизон и преднизолон в индивидуально подобранной дозировке, пожизненно, 2-3 раза в день. 
К сожалению, ЗГТ гомоном роста и тиреоидными препаратами также может привести к проявлению скрытого гипокортицизма.

Диагноз «вторичный гипогонадизм» устанавливается при отсутствии вторичных половых признаков, а также при низких значениях половых стероидов (тестостерон, эстрадиол) и гонадотропинов по достижении пациентом костного возраста, соответствующего 12 - 13 гг. Дефицит половых гормонов в теле человека, помимо прочего, отрицательно влияет на состояние сердечно-сосудистой системы. Заместительная терапия назначается по половому принципу: мужчинам - препараты тестостерона пролонгированного действия (инъекция один раз в 3-4 недели); женщинам - препараты эстрадиола и эстроген-прогестагенового ряда (таблетки, ежедневно) [11]. Назначение щадящей дозы половых стероидов подросткам производится с учётом костного возраста пациента (12 - 13 лет) и достигнутых им показателей роста. С одной стороны, половые стероиды усиливают действие ГР, но с другой половое развитие (а именно эстрогены) влечёт за собой быстрое закрытые зон роста эпифизов длинных трубчатых костей, что, в свою очередь, может стать причиной ранней отмены терапии ГР. Отмена терапии в этом случае является крайне неправильной, поскольку даже после закрытия зон роста, продолжается рост позвоночника, костей гортани и костей черепа, формируя «взрослую» внешность индивида [12]. T.о., назначение стероидов сугубо индивидуально и производится с учётом достигнутого подростком роста. Поскольку костный возраст пациентов с ГН на несколько лет отстаёт от паспортного, получается, что половое развитие подростков стимулируют лишь в позднем подростковом возрасте, обусловливая тем самым его задержку на 2 - 4 года.

Во взрослом возрасте вторичный гипогонадизм у женщин проявляется аменореей, а у мужчин азооспермией, недоразвитием половых органов, импотенцией, слабой выраженностью вторичных половых признаков, снижением или полным отсутствием полового влечения. Вторичный гипогонадизм компенсируется половыми стероидами, однако полноценного полового развития при врождённом МДГ (особенно у девочек) добиться довольно трудно. Бесплодие остаётся превалирующей проблемой пациентов с врождённым МДГ гипофиза отчасти из-за прекращения полноценной ЗГТ после 18 лет. Важно отметить, что в ряде случаев успешной стимуляции полового развития женщин с ГН в репродуктивных целях, главную роль сыграла временная ЗГТ ГР, усилившая действие половых стероидов [13]. К сожалению, в источниках не уточняется, были ли это случаи врождённого или приобретённого гипопитуитаризма. Также зарубежные исследования подтверждают положительный опыт применения тестостероносодержащих препаратов для лечения женщин с дефицитом андрогенов и гипопитуитаризмом.

Сегодня компенсация $\mathrm{CH}$ осуществляется с помощью заместительной терапии синтетическим (рекомбинантным) гормоном роста (рГР). В среднем динамика роста детей на рГР составляет примерно 10 - 12 см в год. Конечный рост пациентов с изолированной СН, как правило, превышает конечный рост пациентов с множественной недостаточностью гормонов гипофиза, и зависит не только от генетических предпосылок, но и от показателей костного возраста [14]. Наличие побочных эффектов или индивидуальной (ин)толерантности к препарату рассматривается как основание к замене текущего препарата на его аналоги. Показанием к прекращению стимуляции роста является закрытие зон роста (на 2 - 4 года позже, чем у сверстников), уменьшение скорости роста до 2 см в год или же достижение конечного роста, но во всех отдельных случаях этот вопрос решается индивидуально. Важно отметить, что прекращение стимуляции роста не означает полную отмену заместительной терапии ГР, которая при тотальном дефиците СТГ теоретически должна продолжаться и во взрослом возрасте с целью коррекции метаболических проявлений СН и ГН.

Во взрослом возрасте ЗГТ может быть назначена, прежде всего, для поддержания метаболического баланса и сердечно-сосудистой системы (ССС), а также для поддержания КЖ на высокому ровне. Что касается ССС, то согласно недавним исследованию, у пациентов с диагностированной в детстве ГН даже после ЗГТ в раннем возрасте её параметры и функционирование отличаются от показателей здоровых людей [15]. В целях повышения эффективности ЗГТ гормоном роста проводится только в комплексном лечении другими гормонами. Задачами терапии являются улучшение композиционного состава тела, повышение минеральной плотности костей, нормализация липидного обмена, улучшение сердечной деятельности, повышение толерантности к физическим и эмоциональным нагрузкам. Эффективность терапии зависит от этиологии ГН и по некоторым сведениям более эффективна в случае приобретённой ГН недостаточности [16].

Поскольку у взрослых секреция гормона роста значительно ниже, по сравнению с детским и особенно подростковым возрастом, пациентам назначаются гораздо более низкая 
«поддерживающая» доза (детям и подросткам назначается более высокая «ростовая» доза ГР). Кроме того, секреция гормона роста имеет половой диморфизм; следовательно, доза пациентов женского пола превышает дозу, необходимую пациентам мужского пола. Доза рассчитывается исходя из веса взрослого пациента, и корректируется в соответствии с клиническими данными и результатами анализа ИФР-1, проводимого раз в 6 месяцев. Стандартная суточная доза для детей составляет 0,033 мг/кг веса пациента и может быть повышена в период пубертата. Клинический эффект препарата у взрослых пациентов обычно наблюдается не ранее, чем через 3 - 6 месяцев после начала лечения.

Нельзя также не отметить важность механизма взаимодействия различных гормонов в теле пациентов разных полов. По данным ряда исследований эффективность ЗГТ ГР у женщин в целом ниже, чем у мужчин [17]. В организме здоровых женщин вырабатывается в 3 раза больше ГР, чем у мужчин, но при этом ИФР-1 у обоих полов примерно одинаков, что означает, что в женском организме реакция на ГР снижена, виной чему могут быть эстрогены. Увеличение дозы ГР не приводит к изменению ситуации. У не леченых женщин с ДГР ИФР-1 также в целом ниже, чем у не леченых мужчин, а при ЗГТ гормоном роста ИФР-1 мужчин в 2 раза превышает женский показатель. Результаты двухлетней терапии показали, что у компенсированных половыми гормонами женщин эффект от ГР достигает определённого уровня и больше не изменяется; андрогены же наоборот лишь усиливают эффект ГР [18]. Таким образом, ЗГТ оказывается более результативной, если пациент с ГН мужского пола.

Что касается дискомфорта и побочных эффектов терапии ГР, то у взрослых пациентов они редко приводят к отказу от лечения. Самыми частыми побочными эффектами являются периферические отёки, которые появляются на 2 - 3 неделе лечения и либо самостоятельно исчезают 2 недели спустя, либо после корректировки вводимой дозы в соответствии с показателями ИФР-1. Вторым распространённым побочным эффектом (у 10 - 20\% пациентов) являются артралгии и миалгии, т.е. боли в суставах и мышцах, появляющиеся к концу первого месяца лечения, которые также проходят после снижения дозы. Кроме того, у пациентов, получающих ЗГТ ГР, иногда наблюдаются внутричерепная гипертензия, головные боли, препубертатная гинекомастия и парестезии (онемения).

Сегодня согласно прописанным стандартам лечения гипопитуитаризма большинство пациентов заканчивают терапию гормоном роста в 16 - 17 лет, что примерно совпадает с переходом молодых людей в ведение медицинских учреждений для взрослого населения. Исследований того, что именно происходит со здоровьем пациентов в этот транзиторный период, придерживаются ли они какого-либо лечения или нет, а также сведений о маршрутизации пациентов недостаточно даже в зарубежных источниках. Теоретически, врачи должны оказывать поддержку и совершать передачу молодых пациентов с хроническими заболеваниями во взрослые клиники. Как ни странно, отсутствие данной практики - явление весьма обычное для большинства стран.

Значимость данного переломного момента в лечении пациентов с ГН отягощается ещё и тем, что период от конечного роста до возраста примерно 25 лет является физиологически крайне важным. В этот период добирается костная и мышечная масса, в полной мере развиваются кости черепа, формируя внешность пациента, для чего необходимо наличие должного уровня ГР в организме. Также на эту стадию приходится психологическое взросление и закладка основ всей взрослой жизни пациентов (образования, карьеры, семейных отношений), требующие больших личностных ресурсов. С одной стороны, после отмены терапии в транзиторный период у пациентов не происходит резкого ухудшения состояния, а вышеуказанные проблемы нарастают только у пациентов с выраженной МДГ. С другой стороны, было обнаружено, что исчезнувшие на время лечения эмоциональные и психосоциальные нарушения вскоре вновь манифестируются после отмены ЗГТ (депрессия, раздражительность, упадок сил, апатия). Причиной может служить то, что в период отмены ЗГТ пациенты испытывают трудности в половой сфере, у них снижается стрессоустойчивость, концентрация внимания и физическая выносливость, ухудшается облик тела и, как следствие, это негативно отражается на уверенности пациентов в себе $[19 ; 20]$. После возвращения к ЗГТ состояние пациентов нормализуется, в немалой степени потому, что причины проблем имеют, прежде всего, нейроэндокринную природу.

Оценка состояния пациентов в транзиторный период вызывает некоторые трудности, особенно в связи с тем, что молодой организм может не давать поводов для обращения в медицинские учреждения. Вернуться к терапии стремятся те пациенты, чей уровень гормонов снижен критически, кто испытывает сильную нехватку энергии и жизненных сил и те, кто прежде чувствовал значительное улучшение состояния здоровья во время ЗГТ, что 
соответствует одному из параметров приверженности лечению. По данным некоторых исследований, количество взрослых пациентов, стремящихся получать лечение ГР, составляло 48\%, по сравнению с 52\% пациентов, отказывающихся от дальнейшей ЗГТ ГР [21].

Во многих исследованиях для оценки результативности лечения принимаются во внимание именно показатели КЖ пациентов. В понимании применительно к медицине, КЖ - это комплексный критерий, используемый для оценки не только эффективности терапии, но и субъективного благополучия пациентов с разными заболеваниями. С 90-х гг. аспект КЖ стал популярным предметом изучения и весомым аргументом при обосновании целесообразности той или иной терапии, в том числе и терапии ГР. Тем не менее, в вопросе назначения ЗГТ ГР взрослым пациентам специалисты предпочитают исходить, прежде всего, из физиологических показателей, а не из субъективной оценки пациентом своего физического и эмоционального состояния [22]. Тем не менее, несмотря на научно обоснованную и убедительно доказанную целесообразность ЗГТ ГР, в нашей стране взрослым пациентам с гипопитуитаризмом всё ещё трудно добиться её получения в силу ряда причин.

КЖ пациентов с ГН измеряется с помощью различного рода тестов. Среди применяемых на Западе инструментов измерения есть ряд неспецифичных для заболевания опросников, например EQ-5D, SF-36, Нотингемский профиль здоровья (Nottingham Health Profile). Tакже существуют две недавно созданные и относительно специфичные для заболевания $($ ГН/ $\mathrm{CH})$ анкеты QLS-H (Questions on Life Satisfaction-Hypopituitarism) и QoL-AGHDA (The Quality of Life Assessment of Growth Hormone Deficiency in Adults) ${ }^{1}$. Показатели здорового населения по анкете QoL-AGHDA в среднем составляют 4,8 $\pm 5,2$, в то время как у декомпенсированных взрослых с ГН они составляют 7,9 $\pm 6,5$ [23]. Однако валидность данной анкеты, состоящей из 25 вопросов, также подвергается критике, поскольку её результаты не отражают картины, специфичной для различных синдромов, включающих в себя СН [24]. В целом вопросы анкеты оценки КЖ вскользь касаются трёх традиционно рассматриваемых уровней здоровья человека: биологического (физиологического), психологического и социального.

В большинстве зарубежных исследований рассматривается влияние именно ГР на КЖ пациентов с ГН. В основном оценка КЖ проводится среди взрослых пациентов. Несмотря на то, что по некоторым данным ГР не оказывал значительного влияния на показатели КЖ, многочисленные последующие исследования всё же свидетельствуют об обратном [25]. Полученные данные доказывают, что ЗГТ ГР приводит к улучшению самочувствия пациентов, что значительно сокращает объём потребляемых ими фармакологических и медицинских услуг как минимум в первые 2 года ЗГТ. Также есть противоречивые данные относительно того, при какой этиологии ГН ЗГТ в большей степени влияет на КЖ пациентов. По некоторым сведениям улучшения показателей КЖ наиболее заметны у пациентов с приобретённым ДГР, поскольку их базовые показатели были ниже, чем у пациентов с врождённым ДГР. По другим сведениям показатели КЖ после начала терапии были выше у взрослых с врождённым ДГР, или же этиология $\mathrm{CH}$ вообще не влияла на результаты. Аналогичная картина наблюдается при сравнении показателей КЖ пациентов с изолированным ДГР и МДГ [26]. Интересно отметить, что линейные показатели роста сами по себе не влияли на результат оценки КЖ. В результатах исследований также присутствует различие по половому признаку: декомпенсированные женщины с ГН более пессимистично оценивали своё состояние, чем мужчины; впрочем, такая тенденция справедлива и для здорового населения.

Улучшения психосоциального статуса как аспекта КЖ пациентов после начала ЗГТ касаются энергичности, активности, настроения, чувства социальной изоляции, чувства тревожности и страха, когнитивных способностей и межличностных взаимоотношений, причём первой достигает нормы чувство социальной изоляции, затем тревожность и уверенность в себе. Показатели энергичности и памяти являются самыми низкими при базовом замере и улучшаются по сравнению с периодом отсутствия ЗГТ, но всё же не достигают нормы здоровых людей. Отношение пациентов с ГН к собственному телу остаётся неизменным, поскольку, несмотря на то, что количество жировых отложений снижается, черты лица и пропорции тела взрослых пациентов практически не меняются [27; 28].

Несмотря на то, что ЗГТ гормоном роста помогает поддерживать КЖ пациентов на достаточно высоком уровне на протяжении всего периода терапии, в различных исследованиях показатели КЖ у пациентов с ГН всё же сильно разнятся. С одной стороны, при наличии

1 Также в литературе упоминаются специфичные для гипопитуитаризма анкеты AHQ (Adult Hypopituitarism Questionnaire, Japan), GHD-LFS (Life Fulfillment Scale), GHD-IS (Impact Scale) и GHDQ (Growth Hormone Deficiency Questionnaire). 
результативной ЗГТ повышение показателей может быть связано с положительными изменениями в структуре тела, с улучшением состояния сердечно-сосудистой системы и увеличением физической выносливости. C другой стороны, данные могут частично варьироваться от исследования к исследованию из-за того, что в одних исследованиях показатели соотносятся с уровнем ГР, а в других с уровнем ИФР-1, что не является тождественным. Показатели также могут колебаться в зависимости от большого числа напрямую не относящихся к ГН факторов, таких как возраст, пол, образование, уровень дохода, вредные привычки, ожирение, депрессия, проблемы со зрением и уровень жизни в стране [29].

Наличие различных факторов, помимо результативности лечения, влияющих на показатели КЖ пациентов, неразрывно связано с патоцентрическим понятием внутренней картины болезни (ВКБ), предложенным Р.Л. Лурия (1930) и с соподчинённым ему саноцентрическим понятием внутренней картины здоровья (ВКЗ), предложенным А.Б. Орловым (1991).

Известно, что ВКБ в значительной степени влияет на психическую деятельность и поведение человека, но, в то же время, также находится в зависимости от его индивидуальнопсихологических особенностей, т.е. и имеет комплексную структуру. В результате самопознания и самонаблюдения любое изменение самочувствия постоянно формирует в сознании человека некие ВКБ и ВКЗ. Помимо прочего, ВКБ определяется типом отношения личности к болезни, на который также может влиять пол, возраст, характер человека, его темперамент, система ценностей, социальные стереотипы и представления, система отношений индивида и другие особенности личности. Традиционно рассматриваются такие составляющие ВКБ как сенситивный компонент, эмоциональный, когнитивный и волевой. В зависимости от типа реагирования на свою болезнь, пациент может переоценивать опасность своего состояния, недооценивать его, отрицать наличие заболевания или же относиться к нему гармонично. Наиболее распространённая отечественная классификация типов отношения личности к болезни была дана А.Е. Личко и Н.Я. Ивановым (1980), и может применяться практически к любому заболеванию [30]. Адекватная ВКБ обеспечивает хорошую приверженность пациентов лечению. Иначе обстоит дело с ВКЗ, поскольку у каждого человека есть некая своя индивидуальная, им одним установленная норма своего физического и душевного состояния. С точки зрения психологии, ВКЗ рассматривается не столько как состояние отсутствия болезни, сколько как некий продуктивный потенциал личности.

Но как будет выглядеть ВКЗ, сложившаяся у взрослого человека с врождённым неизлечимым заболеванием, например, таким как гипопитуитаризм? Можно предположить, что ВКЗ у таких пациентов либо не может быть по определению, или же она должна сильно отклоняться от общих норм. Однако если человек с врождённым заболеванием адаптируется к нему и соотносит своё состояние не с объективным состоянием здоровья, а лишь с состоянием болезни в стадии ремиссии, мало изменяющимся во времени, то отсутствие обострений, неожиданно накладывающих отпечаток на повседневную жизнедеятельность, может восприниматься пациентом с врождённым заболеванием как состояние здоровья, по врачебным меркам при этом не являясь таковым. На наш взгляд этим может быть отчасти обусловлен распространённый анозогнозический тип отношения к болезни у таких пациентов, но только не в его традиционном понимании. Анозогнозия в данном случае - это, возможно, не отрицание своей болезни и избегание статуса больного, а именно отсутствие в опыте человека информации об альтернативном состоянии некого эталонного здоровья. В связи с этим, прерывистый характер 3ГТ как раз может дать больному новое представление о потенциале здоровья и положительно повлиять на его приверженность лечению, о чём говорилось и в зарубежных исследованиях (Holmes et al.). В любом случае, следует отметить, что ВКБ, ВКЗ и адаптационный потенциал пациентов с ГН ранее практически не изучались. Многоплановость данного вопроса требует соответствующего инструментария и рассмотрения в рамках отдельного исследования.

Таким образом, обусловленные физическим состоянием и дефицитом гормонов, у взрослых с ГН могут наблюдаться серьёзные физиологические проблемы, а также трудности социального и психосоматического характера, что получает числовое выражение при оценке КЖ таких пациентов с помощью анкет. В целом ЗГТ оказывает положительное влияние на состояние и КЖ пациентов, а прекращение ЗГТ чревато как негативными последствиями, проявляющимися в ухудшении физического и эмоционального состояния пациентов и снижении показателей КЖ, так и позитивными, поскольку это может изменить параметры ВКЗ пациента и повлиять на его дальнейшую приверженность лечению. 


\section{Список литературы / References}

1. Jostel A., Lissett C., Shalet S.M. Hypopituitarism. In: Endocrinology (ed. L. DeGroot), W.B. Saunders, New York, 2005.

2. Дедов И.И., Тюльпаков А.Н., Петеркова В.А. Соматотропная недостаточность. М. «ИндексПринт», 1998. 312 с.

3. Maruff P., Falleti M. Cognitive Function in Growth Hormone Deficiency and Growth Hormone Replacement. Hormone Research, 2005. 64: 100-108.

4. Nyberg F., Burman P. Growth hormone and its receptors in the central nervous system: location and functional significance. Hormone Research, 1996. 45:18-22.

5. Burman P., Broman J.E., Hetta J., Wide L. et al. Growth hormone treatment affects brain neurotransmitters and thyroxine. Clinical Endocrinology, 1996. 44:3. 319-324. [Electronic resource] URL: http://onlinelibrary.wiley.com/doi/10.1046/j.1365-2265.1996.617439.x/full/ (date of access: 03.03.2017).

6. Дедов И.И., Петеркова В.А., Безлепкина О.Б., Нагаева Е.В. Соматотропная недостаточность у взрослых: Атлас. М., 2004. 90 с.

7. Федеральные клинические рекомендации (протоколы) по ведению детей с эндокринными заболеваниями. Под ред. И.И. Дедова и В.А. Петерковой. М. «Практика», 2014. 442 с.

8. Шитова А. В. Психофизиологические особенности и проблемы психосоциальной адаптации пациентов с гипопитуитаризмом. // Проблемы современной науки и образования, 2017. № 8 (90). C. 104-110.

9. Rosen T., Bengtsson B.A., 1990. Premature mortality due to cardiovascular disease in hypopituitarism. Lancet. 336: 285-288.

10. Van Bunderen C.C., Van Nieuwpoort I.C. et al. Does growth hormone replacement therapy reduce mortality in adults with growth hormone deficiency? Data from the Dutch National Registry of Growth Hormone Treatment in adults. J Clin Endocrinol Metab., 2011. Oct; 96 (10):3151-9. [Electronic resource]. URL: http://www.ncbi.nlm.nih.gov/pubmed/21849531/ (date of access: 01.03.2017).

11. Jostel A., Lissett C., Shalet S. M. Hypopituitarism. In: Endocrinology (ed. L. DeGroot), W.B. Saunders, New York 2005.

12. Hulthen L., Bengtsson B.A. et al. GH is needed for the maturation of muscle mass and strength in adolescents. J Clin Endocrinol Metab 2001; 86: 4765-4770. [Electronic resource]. URL: https://www.researchgate.net/publication/11748951_GH_Is_Needed_for_the_Maturation_of_Mus cle_Mass_and_Strength_in_Adolescents/(date of access: 03.03.2017).

13. Витязева И.И., Бармина И.И., Прудникова Н.Ю. Использование методов вспомогательных репродуктивных технологий в лечении пациенток с гипогонадотропным гипогонадизмом. // Репродуктивные технологии сегодня и завтра. Материалы XXIII Международной конференции Российской Ассоциации Репродукции Человека (4-7 сентября 2013 г. Волгоград). Волгоград, 2013. С. 23-24. [Электронный ресурс]. Режим доступа: http://www.rahr.ru/d_pech_mat_konf/Tezis_2013.pdf/ (дата обращения: 02.03.2017).

14. Wit J.M., Rekers-Mombarg L.T.M. Final Height Gain by GH Therapy in Children with Idiopathic Short Stature Is Dose Dependent. The Journal of Clinical Endocrinology \& Metabolism 87 (2): 604-611. [Electronic resource]. URL: http://press.endocrine.org/doi/pdf/10.1210/jcem.87.2.8225/ (date of access: 05.03.2017).

15. Sandberg D.E., MacGillivray M.H. Growth hormone therapy in childhood-onset growth hormone deficiency: adult anthropometric and psychological outcomes. Endocrine, 2000. Apr. 12 (2):173-82.

16. Attanasio A.F., Lamberts S.W. et al. Adult growth hormone (GH)-deficient patients demonstrate heterogeneity between childhood onset and adult onset before and during human GH treatment. Adult Growth Hormone Deficiency Study Group. J Clin Endocrinol Metab., 1997. Jan. 82 (1):82-8.

17. Traggiai C., Stanhope R., 2007. Management of GHD in Children and Adults. Prescriber. 18 (9). 67-71.

18. Münzer T. et al. Growth Hormone and Sex Steroid Effects on Serum Glucose, Insulin, and Lipid Concentrations in Healthy Older Women and Men. J Clin Endocrinol Metab., 2009. Oct. 94(10): 3833-3841. [Electronic resource]. URL: http://www.ncbi.nlm.nih.gov/pmc/articles/PMC2758730/ (date of access: 01.03.2017).

19. Leong G.M., Johannsson G. Growth Hormone Deficiency: Strategies and Indications to Continue Growth Hormone Therapy in Transition from Adolescence to Adult Life. Hormone Research, 2003. 60: 78-85. 
20. McMillan C.V., Bradley C., Gibney J. et al. Psychological effects of withdrawal of growth hormone therapy from adults with growth hormone deficiency. Clin Endocrinol (Oxf), 2003. Oct. 59 (4): 467-75. [Electronic resource]. URL: http://www.ncbi.nlm.nih.gov/pubmed/14510909/ (date of access: 04.03.2017).

21. Holmes S.J., Shalet S.M. Factors influencing the desire for long-term growth hormone replacement in adults. 1995 Clin Endocrinol (Oxf) 43: 151-157. [Electronic resource]. URL: http://www.ncbi.nlm.nih.gov/pubmed/7554309/ (дата обращения: 04.03.2017).

22. Wallman H.A., Abs R., Koltowska-Haggstrom M. et al. Interruption of growth hormone replacement during transition negatively impacts lipid profile and quality of life in young adults: analysis of longitudinal data from KIGS and KIMS. 13th International Congress of Endocrinology, November 8-12, 2008 Rio de Janeiro, Brazil.

23. McKenna S.P.; Doward L.C. et al. (1999). The QoL-AGHDA: An instrument for the assessment of quality of life in adults with growth hormone deficiency. Quality of Life Research 8 (4): 373-83.

24. Hull K.L., Harvey S. Growth hormone therapy and Quality of Life: possibilities, pitfalls and mechanisms. J Endocrinol., 2003. Dec. 179 (3): 311-33. [Electronic resource]. URL: http://joe.endocrinology-journals.org/content/179/3/311.full.pdf/ (date of access: 05.03.2017).

25. Koltowska-Haggstrom M. Quality of Life in Adult Patients with Growth Hormone Deficiency. Dissert. Uppsala University, Sweden. 2007. 124 pp. [Electronic resource]. URL: http://www.divaportal.org/smash/get/diva2:171178/FULLTEXT01.pdf (дата обращения: 06.03.2017).

26. Sommer G., Gianinazzi M.E. et al. Health-Related Quality of Life of Young Adults Treated with Recombinant Human Growth Hormone during Childhood. PLoS One, 2015. Oct 16. 10 (10):e0140944. [Electronic resource]. URL: http://www.ncbi.nlm.nih.gov/pmc/articles/PMC46087 86/ (date of access: 06.03.2017).

27. Klose M., Rasmussen A.K. et al. Quality of Life in Adult Hypopituitary Patients Treated for Growth Hormone Deficiency. The Open Endocrinology Journal, 2012, 6: 91-102. [Electronic resource]. URL: http://benthamopen.com/contents/pdf/TOEJ/TOEJ-6-91.pdf/ (date of access: 06.03.2017).

28. Riva G., Molinari E. Body image and social attitude in growth-hormone-deficient adults. Percept Mot Skills., 1995. Jun. 80 (3 Pt 2):1083-8.

29. Вассерман Л.И., Трифонова Е.А. Дискуссионные вопросы концептуализации и методологии исследования качества жизни в медицине. // Сибирский психологический журнал. № 26, 2007. С. $112-119$.

30. Вассерман Л.И, Иовлев Б.В., Карпова Э.Б, Вукс А.Я. Психологическая диагностика отношения к болезни: Пособие для врачей. СПб, 2005. $33 \mathrm{c}$. 


\title{
ИССЛЕДОВАНИЕ О ХАРАКТЕРИСТИКАХ ФОРМИРОВАНИЯ СДВИГОВОГО РАЗРУШЕНИЯ В ТРЁХМЕРНОМ НАПРЯЖЕННОМ СОСТОЯНИИ
}

\author{
Кан М.Г. ${ }^{1}$, Кан И.М. ${ }^{2}$ Email: Kang1791@ scientifictext.ru
}

\author{
${ }^{I}$ Кан Мен Гук-кандидат геологических наук, преподаватель, \\ кафедра тектонической геологии, факультет геологической разведки, \\ университет Хванбук, г. Саривон; \\ ${ }^{2}$ Кан Ир Мен - кандидат геологических наук, преподаватель, \\ кафедра тектонической геологии, геологический факультет, \\ университет им. Ким Ир Сена, г. Пиеньяне, \\ Корейская Народно-Демократическая Республика
}

\begin{abstract}
Аннотация: многие геологические явления природы образуются в течение длительного периода сложных процессов, таких как седимент, гибка и резка. Изучением этого проиесса занимается геологическая тектоника. Геодинамика как основа структурной геологии играет очень важную роль в объяснении геологических структур. Потому что получено много данных, которые используются при интерпретации динамики. Поэтому необходимо срочно создать просто модель сложного геологического тела и применять его на ресурс разведки. В этой статье обсуждается математическая модель для интерпретации механизма формирования сдвигового разрушения. В статье поясняется, как положения поверхности для формирования сдвигового разрушения отличаются в 2-осевых и 3-осевых напряженных состояний.
\end{abstract}

Ключвые слова: сдвигового разрушения, напряжение, математической модели, коэффициент внутреннего трения, отношение напряжения.

\section{STUDY ON THE FORMATION OF SHEAR FRACTURE IN THREE- DIMENSIONAL STRESS SYSTEM Kang M.G. ${ }^{1}$, Kang I.M. ${ }^{2}$}

\author{
${ }^{I}$ Kang Myong Guk - Candidate of geological sciences, Lecturer, \\ GEOLOGICAL EXPLORATION FACULTY HVANBUK UNIVERSITY, SARIWON; \\ ${ }^{2}$ Kang Il Myong-Candidate of geological sciences, Lecturer, \\ DEPARTMENT OF TECTONIC GEOLOGY, FACULTY OF GEOLOGY, \\ UNIVERSITY OF KIM IL SUNG, PYONGYANG, \\ DEMOCRATIC PEOPLE'S REPUBLIC OF KOREA
}

\begin{abstract}
Absrast: many geological phenomena of nature are formed for long periods of complex processes such as sedimentation, bending, and cutting. Studying of this process is geological tectonics. The basis of structural geology, geodynamics, is very important in explaining geological structures. Because many of the data obtained from the field are used in the interpretation of the dynamics. Therefore, it is urgently required to create a simple model of complex geological body and to apply it to resource exploration. This article introduces a mathematical model for interpreting the shear fracture mechanism. In the article, it is discussed how the position of the advantageous plane for the formation of the shear fracture is different in the 2 axial and 3 axial stress states.
\end{abstract}

Keywords: shear fracture stress, mathematical model, coefficient of internal friction, stress ratio.

УДК 551.1

При изучении формирования сдвигового разрушения во избежание сложности исследователи обычно считали, что сдвиговое разрушение включает в себя $\sigma_{2}$-ось [1]. Но другие исследователи утверждают, что $\sigma_{2}$-ось играет определенную роль в формировании сдвигового разрушения и при некоторых случаях поверхность сдвигового разрушения обсуждать, что не включается $\sigma_{2}$-ось в него $[2,3]$.

В статье оценили по установке математической модели и моделированию числового значения, какая поверхность самая выгодная в формировании сдвигового разрушения, в каком случае поверхность сдвигового разрушения не включает $\sigma_{2}$-ось и каков угол отклонения.

1. Установка математической модели 
Математическая модель для определения самой выгодной поверхности в формировании сдвигового разрушения может быть установлена следующим образом.

$$
\sigma_{\mathrm{s}}-\mu \sigma_{\mathrm{n}}=\text { наименьщее }
$$

Тангенциальное напряжение $\left(\sigma_{\mathrm{s}}\right)$ и нормальное напряжение $\left(\sigma_{\mathrm{n}}\right)$ в состоянии трёхмерного напряжения выражается через уравнение (2 и 3).

$$
\begin{gathered}
\sigma \mathrm{s}=\sigma_{0} \mathrm{n}-\left[\mathrm{n}^{\mathrm{T}} \sigma_{0} \mathrm{n}\right] \mathrm{n} \\
\sigma_{\mathrm{n}}=\sigma_{0} \mathrm{n}
\end{gathered}
$$

где $\mu$ - коэффициент внутреннего трения, $\sigma_{0}=\operatorname{diag}(1, \Phi, 0), \mathrm{n}-$ единичный нормальный вектор плоскости, $\Phi$ - отношение главного напряжения $\left(\Phi=\left(\sigma_{2}-\sigma_{3}\right) /\left(\sigma_{1}-\sigma_{3}\right)\right)$.

Для удобства обсуждения согласовали систему главного напряжения с координатной системой, т.е. фиксировали $\sigma_{1}$-ось в направлении север-юг, $\sigma_{2}$-ось в направлении восток-запад и $\sigma_{3}$-ось в направлении вверх-вниз. Таким образом, формула $\left(\sigma_{s}-\mu \sigma_{n}\right)$ представлена следующим образом.

$$
\sigma_{\mathrm{b}}-\mu \sigma_{\mathrm{n}}=\left(\mathrm{x} \sigma_{0} \mathrm{~T}-\mathrm{xT}^{\mathrm{E}} \sigma_{0} \mathrm{~T} \mathrm{ъ} \mathbf{~ т ~ ъ ~}^{\mathrm{E}} \mathrm{x}_{0} \mathrm{~T}-\mathrm{xт}^{\mathrm{E}} \sigma_{0} \text { т ъ т ъ }\right)^{1.2}-\mu \mathrm{xт}^{\mathrm{E}} \sigma_{0} \text { тъ }
$$

Оно будет определяться с помощью численного расчета, потому что, трудно определить максимальное значение уравнения (4) аналитическим методом. В статье выяснили, как различать состояния положения благоприятные значения элементы положения в состояниия напряжения 2-оси и 3-оси. Для того чтобы изучали способ изменения обсужденного состояния положения при изменении значения отношения главного напряжения $\Phi$ и значения коэффициент внутреннего трения $\mu$ (рис. 1).
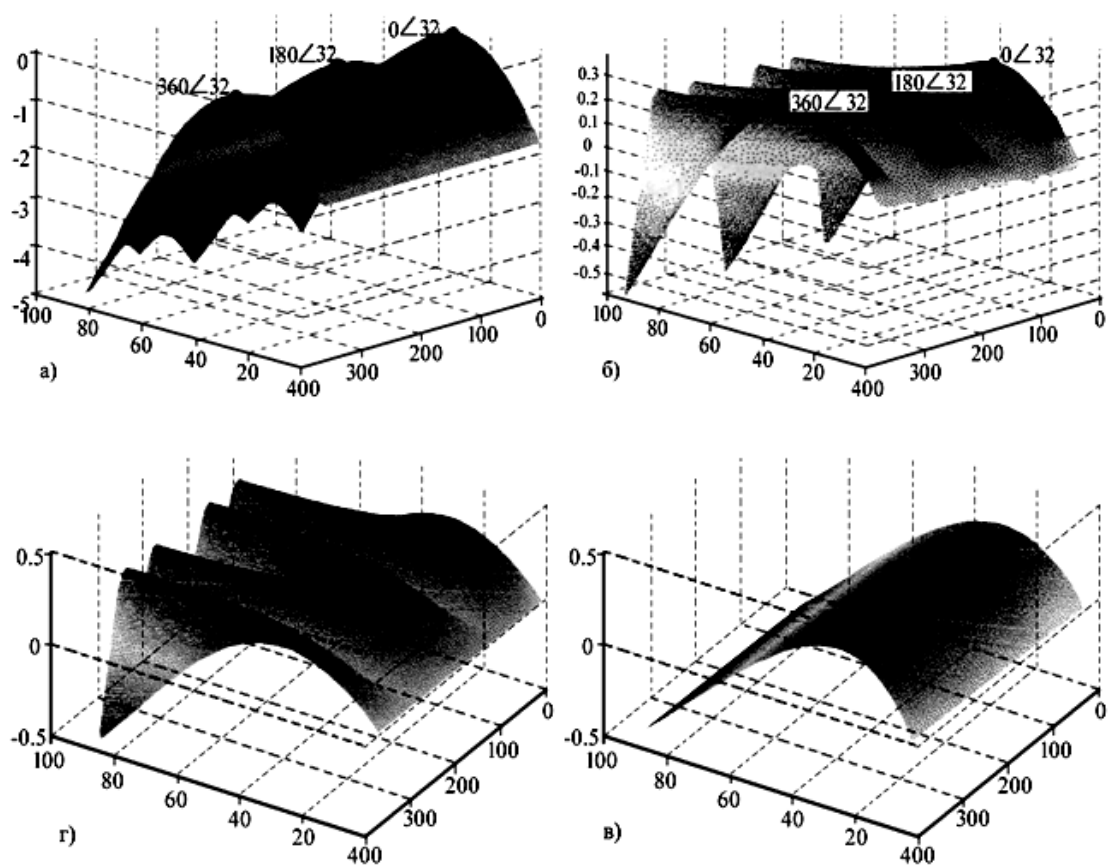

Рис. 1. Наиболее благоприятные элементы положения для формирования сдвигового разрушения $(\mu=0,5$, $\Phi=0,9)$

$$
\text { a) } \mu=0,5, \Phi=0,9 \text {, б) } \mu=0,5, \Phi=0,1, \text { в) } \mu=0,5, \Phi=1,0 \text {, г) } \mu=0,5, \Phi=0
$$

В а) и б) рисунка 1 (при этом случае $\mu=0,5, \Phi=0,9, \mu=0,5, \Phi=0,1$ ) показаны элемент положения, который возможность самой высокой плоскости при формировании сдвигового разрушения, т.е. знание $(\sigma s-\mu \sigma n)$ максимально. Если в этом состоянии элемент положения $180 / 32,360 / 32$, поверхность включает $\sigma_{2}$-ось и $\sigma_{1}$-ось встречает с $32^{\circ}$. Через это можно узнать, что $\sigma_{2}$-ось включает в сдвиговом разрушении.

Наиболее благоприятные значения элементы положения показаны в таблицах 1 и 2. 
Таблииа 1. Изменение элементов положения возможной поверхности в сдвиговом разрушении по изменению $\mu$

\begin{tabular}{|c|c|c|c|c|}
\hline \multirow{2}{*}{$\boldsymbol{\mu}$} & \multicolumn{2}{|c|}{ Поверхность 1 } & \multicolumn{2}{c|}{ Поверхность 2 } \\
\cline { 2 - 5 } & азимут падения ( $\left(^{\circ}\right)$ & угол падения $\left(^{\circ}\right)$ & азимут падения $\left(^{\circ}\right)$ & угол падения $\left(^{\circ}\right)$ \\
\hline 0 & 360 & 45 & 180 & 45 \\
\hline 0,1 & 360 & 42 & 180 & 42 \\
\hline 0,2 & 360 & 39 & 180 & 39 \\
\hline 0,3 & 360 & 37 & 180 & 37 \\
\hline 0,4 & 360 & 34 & 180 & 34 \\
\hline 0,5 & 360 & 32 & 180 & 32 \\
\hline 0,6 & 360 & 30 & 180 & 30 \\
\hline 0,7 & 360 & 28 & 180 & 28 \\
\hline 0,8 & 360 & 26 & 180 & 26 \\
\hline 0,9 & 360 & 24 & 180 & 23 \\
\hline 1 & 360 & 23 & 180 & \\
\hline
\end{tabular}

В табл. 1 показано, что угол падения возможной поверхности в сдвиговом разрушении изменяется с помощью коэффициента внутреннего трения.

Таблица 2. Изменение элементов положения возможной поверхности в сдвиговом разрушении по изменению $Ф$

\begin{tabular}{|c|c|c|c|c|}
\hline & \multicolumn{2}{|c|}{ поверхность 1} & \multicolumn{2}{|c|}{ поверхность 2} \\
\hline$\Phi$ & азимут падения $\left({ }^{\circ}\right)$ & угол падения ( $\left.{ }^{\circ}\right)$ & азимут падения $\left({ }^{\circ}\right)$ & угол падения (०) \\
\hline 0,1 & 360 & 30 & 180 & 30 \\
\hline 0,2 & 360 & 30 & 180 & 30 \\
\hline 0,3 & 360 & 30 & 180 & 30 \\
\hline 0,4 & 360 & 30 & 180 & 30 \\
\hline 0,5 & 360 & 30 & 180 & 30 \\
\hline 0,6 & 360 & 30 & 180 & 30 \\
\hline 0,7 & 360 & 30 & 180 & 30 \\
\hline 0,8 & 360 & 30 & 180 & 30 \\
\hline 0,9 & 360 & 30 & 180 & 30 \\
\hline
\end{tabular}

В табл. 2 можно знать, что элементы положения возможной поверхности в сдвиговом разрушении не изменяют, когда отношение главного напряжения изменяется при интервале значения $0,1-0,9$. Поэтому при случае $\sigma_{1}<\sigma_{2}<\sigma_{3}$, в трёхмерном напряженном состоянии поверхность для формирования сдвигового разрушения почти похоже на состояние напряжения $\sigma_{2}$-оси. Но в рисунке 1 в) и г) отличаются от а) и б).

Как показано в рис. 1 в), при этом случае $\Phi=1$ поверхность сдвигового разрушения может возникнуть во всех азимутах падения с углами падения $32^{\circ}$, т.е. при $\sigma_{1}=\sigma_{2}$ азимуты падения равны, но сдвиговые разрушения с различными азимутами падения могут быть сформированы на одном из напряженного состояния. И в случае $\Phi=0$ возможных значений элементов положений можно изменить в пределе с $0 / 32^{\circ}$ до $60 / 90^{\circ}, 120 / 90^{\circ}-180 / 32^{\circ}, 180 / 32^{\circ}-240 / 90^{\circ}$ и с $300 / 90^{\circ}$ до $0 / 32^{\circ}$.

По этих результатов, можно показать, что, когда значение Ф составляет около 0 или 1 , с помощью различных факторов окружения, таких как неоднородностью среды, сдвигового разрушения может развиваться вдоль плоскости, которая не включает в себя 2-оси с определенным углом отклонения

\section{Выход}

1. Как и в напряженном состоянии 2-оси, так в состоянии напряжении 3-оси поверхность с $\sigma_{\mathrm{s}}-\mu \sigma_{\mathrm{n}}=$ наименьщее можно касаться наиболее благоприятным для формирования сдвигового разрушения, и математическая модель может быть создана.

2. Внутренний коэффициент трения $\mu$ влияет на угол наклона сдвигового разрушения. И, когда величина $\Phi$ отношения напряжений 0 или 1 , сдвиги различных систем могут быть созданы. Но тогда $0<\Phi<1$, в гомогенной среде, только сдвиговый разрыв две системы сопряжения всегда образуется. 


\section{Сиисок литературы / References}

1. Byon Ju Hyok, The study on the method for fault system boundary by element laying of fault, candidate degree thesis, 2014.

2. Morris Alan $P$. The importance of the effective intermediate principal stress $\left(\sigma_{2}\right)$ to fault slip patterns, Journal of Structural Geology. 31 (2009), 950-959.

3. Haimson Bezalel. The effect of the intermediate principal stress on fault formation and fault angle in siltstone, Journal of Structural Geology. 32 (2010). 1701-1711. 


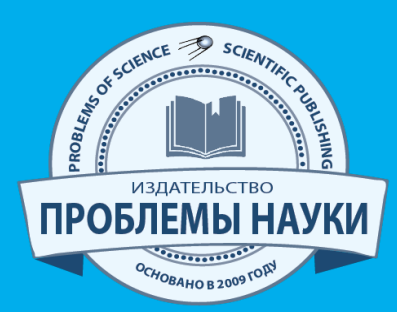

НАУЧНО-МЕТОДИЧЕСКИЙ ЖУРНАЛ

«ПРОБЛЕМЫ СОВРЕМЕННОЙ НАУКИ И ОБРАЗОВАНИЯІ

PROBLEMS OF MODERN SCIENCE AND EDUCATION»

ИЗДАТЕЛЬСТВО «ПРОБЛЕМЫ НАУКИ»

http://www.ipi1.ru

ISSN 2304-2338(Print)

ISSN 2413-4635(Online)

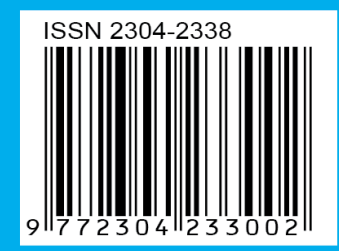

